\title{
GROUND-WATER RESOURCES \\ OF CAMBRIAN AND ORDOVICIAN CARBONATE ROCKS \\ IN THE VALLEY AND RIDGE PHYSIOGRAPHIC PROVINCE OF PENNSYLVANIA
}

by Albert E. Becher

U.S. GEOLOGICAL SURVEY

Open-File Report 90-109

prepared in cooperation with

PENNSYLVANIA DEPARTMENT OF ENVIRONMENTAL PROTECTION, BUREAU OF TOPOGRAPHIC AND GEOLOGIC SURVEY

Lemoyne, Pennsylvania 


\title{
U.S. DEPARTMENT OF THE INTERIOR
}

BRUCE BABBITT, Secretary

\author{
U.S. GEOLOGICAL SURVEY \\ Gordon P. Eaton, Director
}

For additional information

write to:

District Chief

U.S. Geological Survey

840 Market Street

Lemoyne, Pennsylvania 17043-1586
Copies of this report may be purchased from:

U.S. Geological Survey

Branch of Information Services

Box 25286

Denver, Colorado 80225-0286 


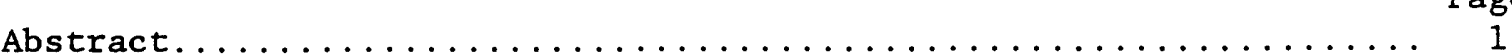

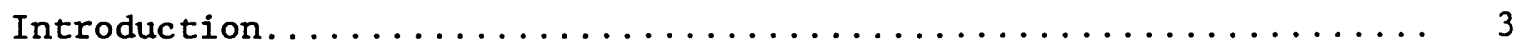

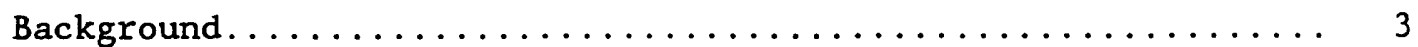

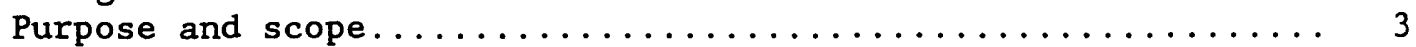

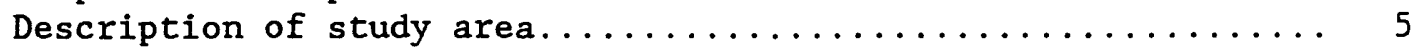

Location and physiographic setting............. 5

Geologic setting....................... 5

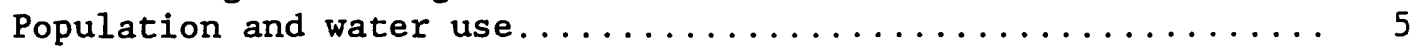

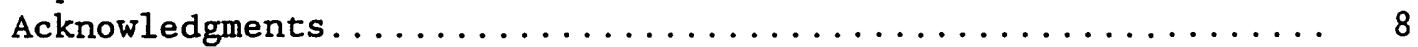

Hydrogeology ................................ 9

Stratigraphy and general water-bearing properties of

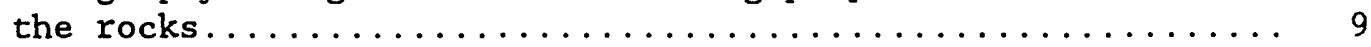

Reedsville Formation..................... 9

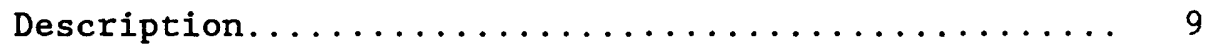

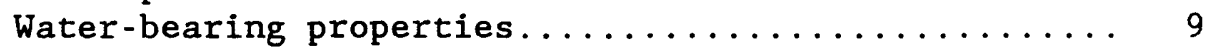

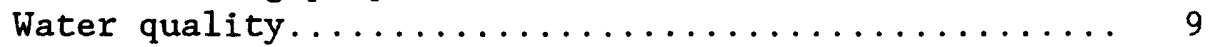

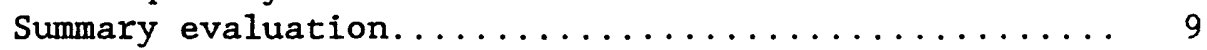

Coburn, Salona, and Nealmont Formations, undivided...... 11

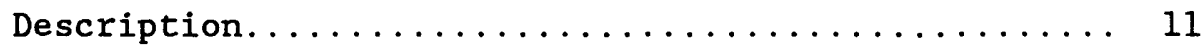

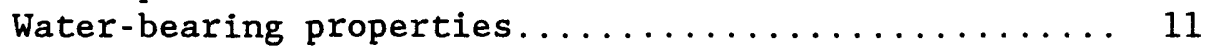

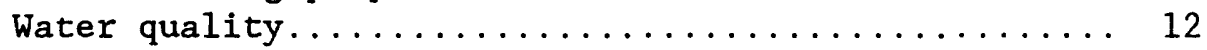

Summary evaluation................... 12

Benner, Snyder, Hatter, and Loysburg Formations,

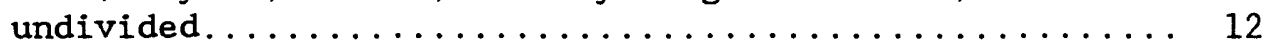

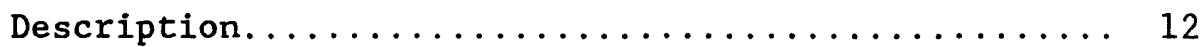

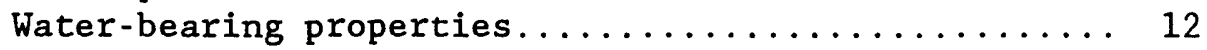

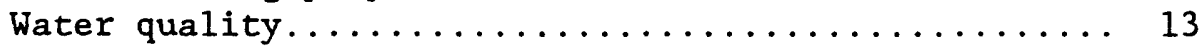

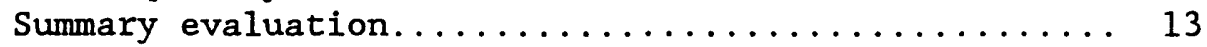

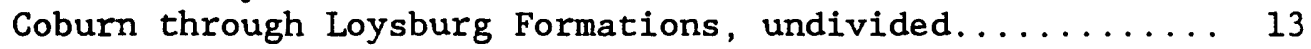

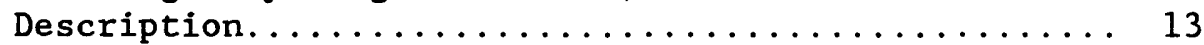

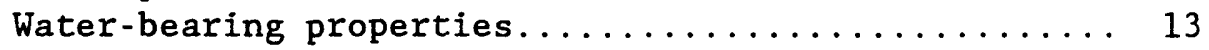

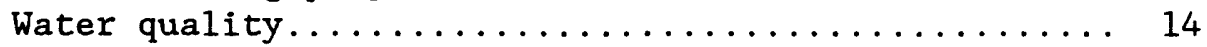

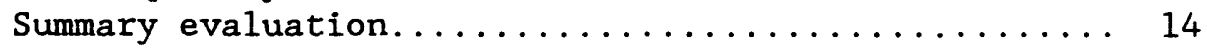

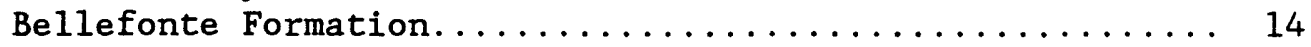

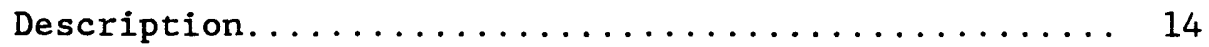

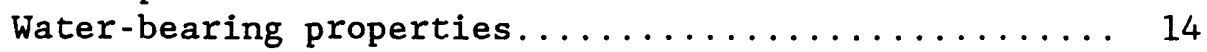

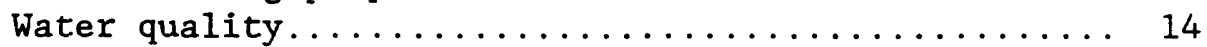

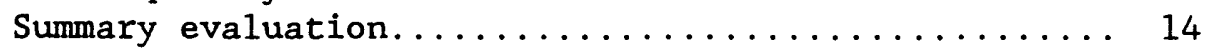

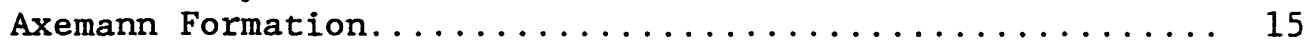

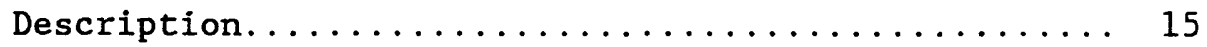

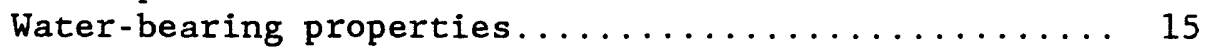

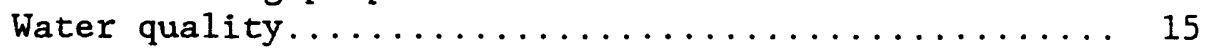

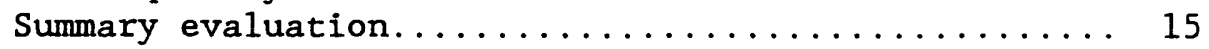

Bellefonte, Axemann Formations, undivided.......... 15

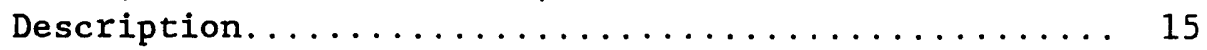

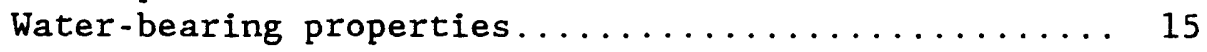

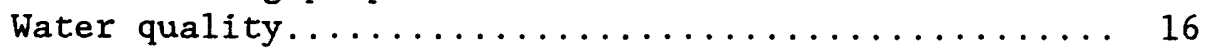

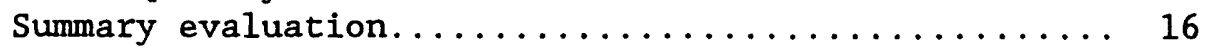

Rockdale Run, Nittany, Nittany and Larke, and Stonehenge

Formations......................... 16 
Hydrogeology - - Continued

Rockdale Run Formation..................... 16

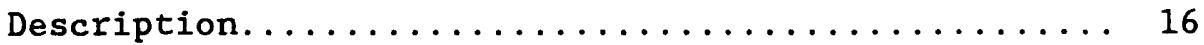

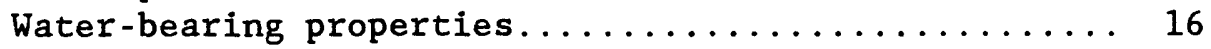

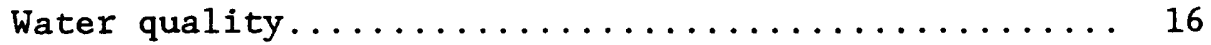

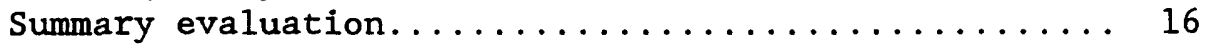

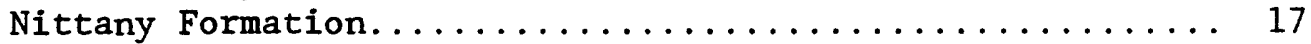

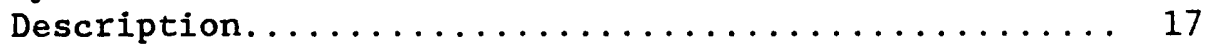

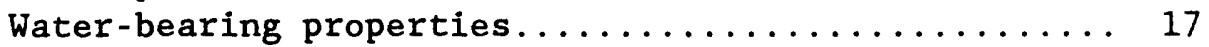

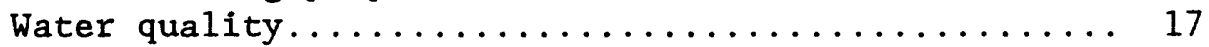

Summary evaluation.................... 17

Nittany and Larke Formations, undivided........... 18

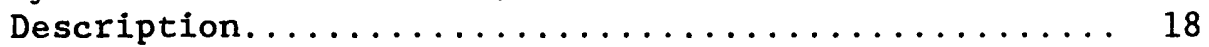

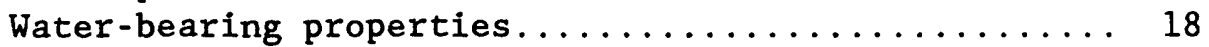

Water quality.......................... 18

Summary evaluation................... 18

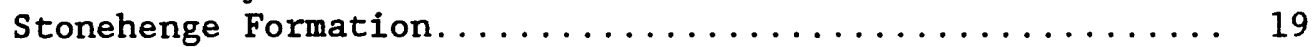

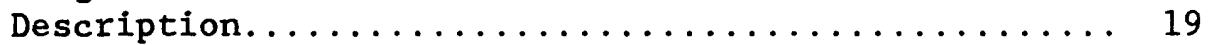

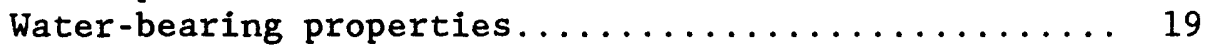

Water quality...................... 19

Summary evaluation................... 19

Shadygrove and Gatesburg Formations............... 19

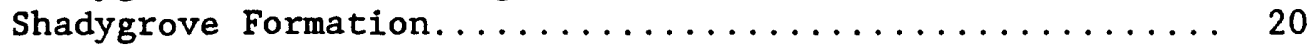

Description....................... 20

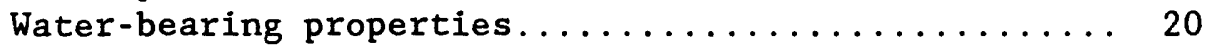

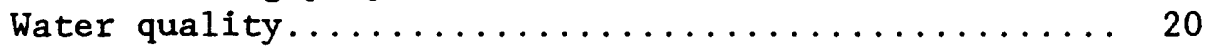

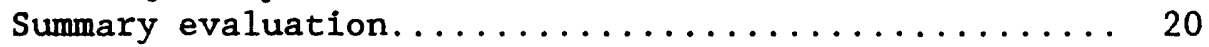

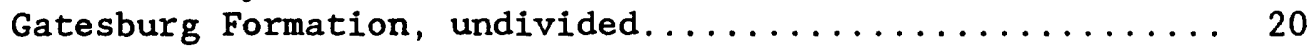

Description........................... 20

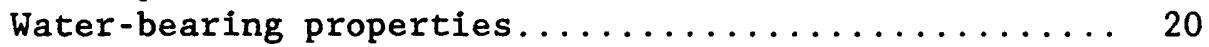

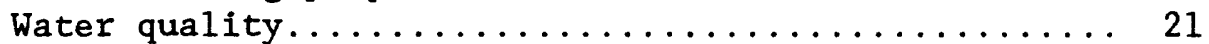

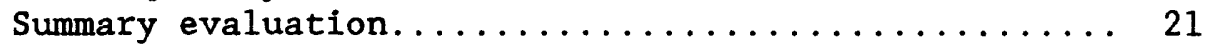

Mines Member of Gatesburg Formation .............. 21

Description........................... 21

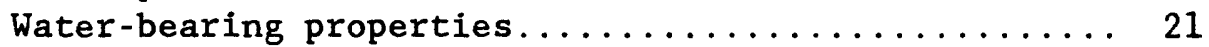

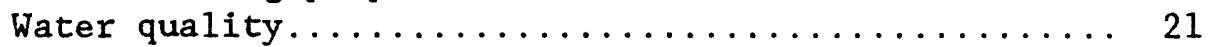

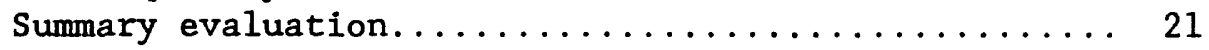

Lower members of Gatesburg Formation.............. 22

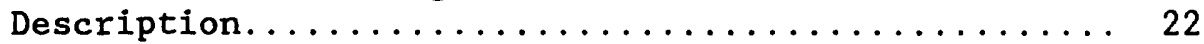

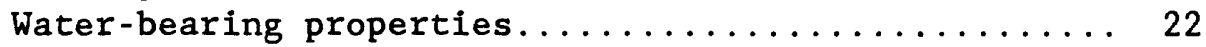

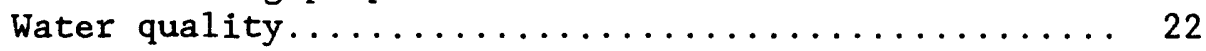

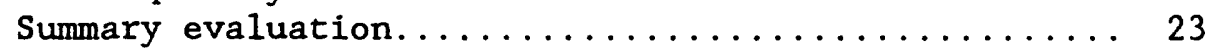

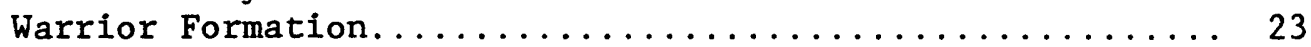

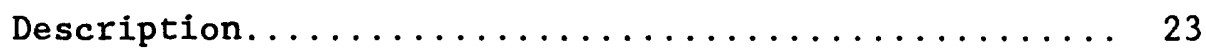

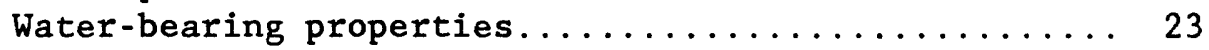

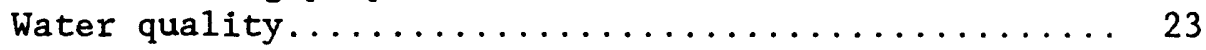

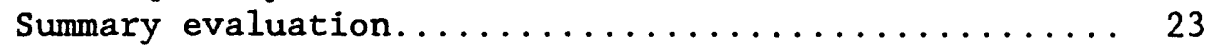

Pleasant Hill and Waynesboro Formations............. 24

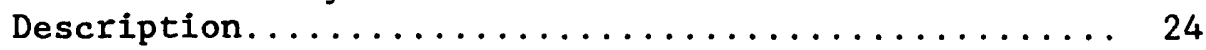

Summary evaluation...................... 24 
Hydrogeology - - Continued

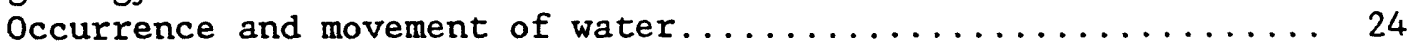

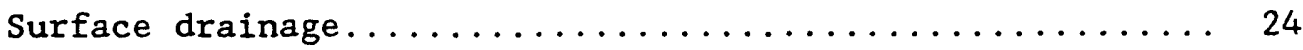

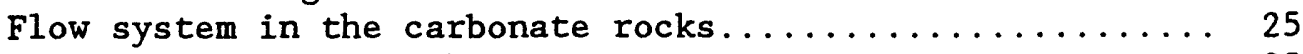

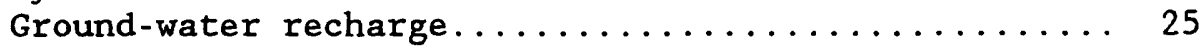

Water levels........................ 28

Relation between ground water and

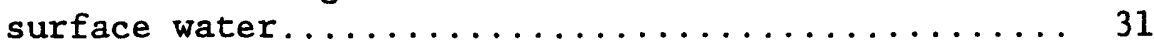

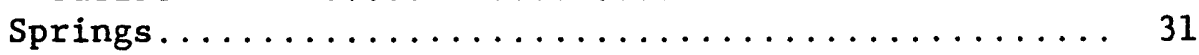

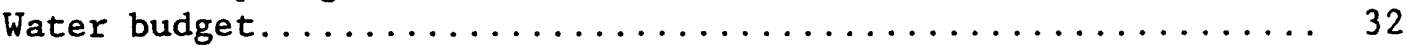

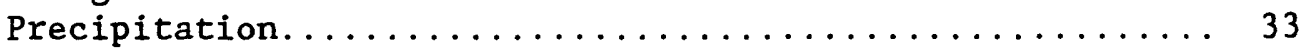

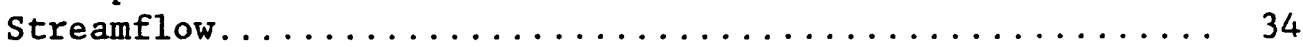

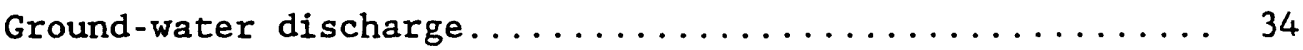

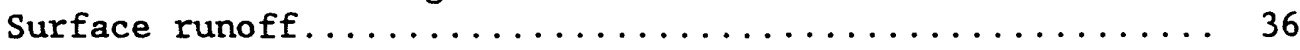

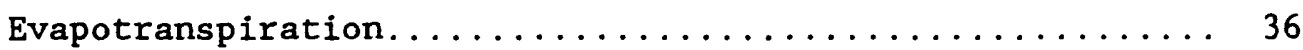

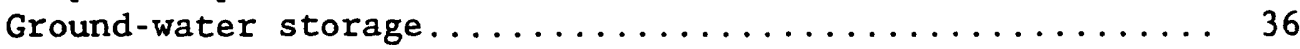

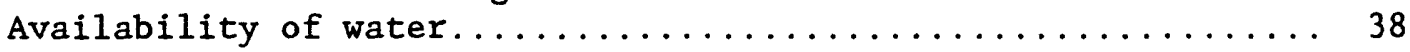

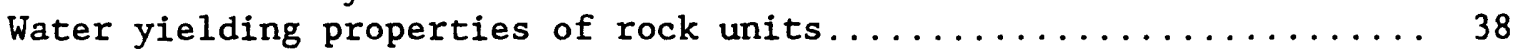

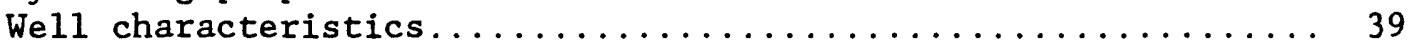

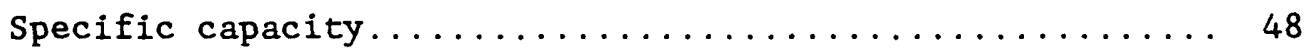

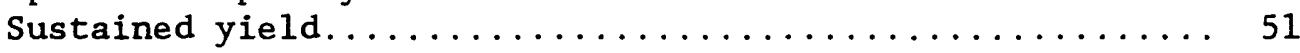

Factors that influence the yield of wells............. 52

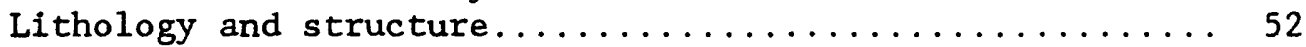

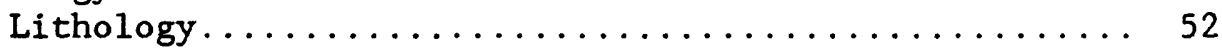

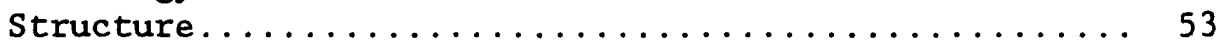

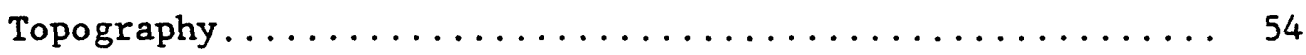

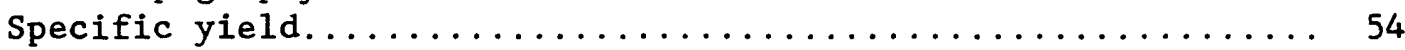

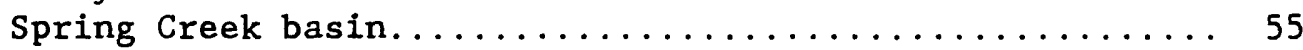

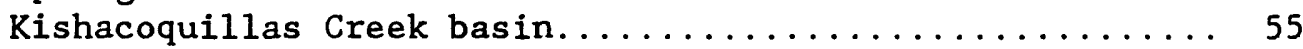

Hydraulic characteristics and well interference........... 56

Problems related to water availability............... 56

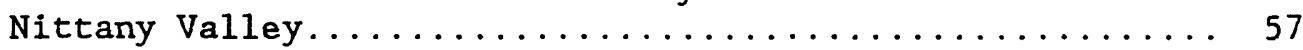

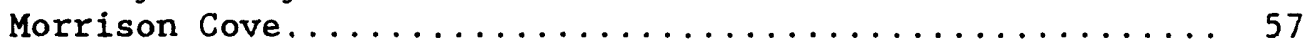

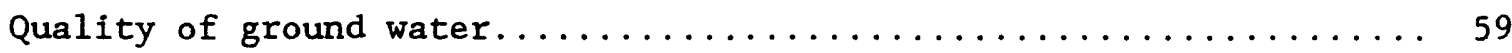

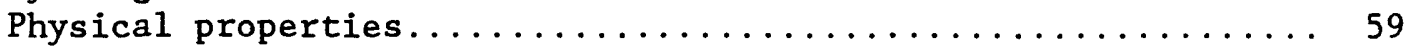

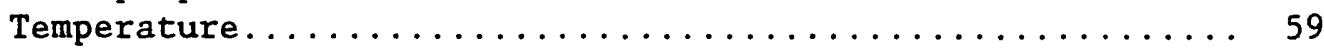

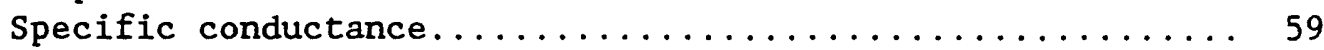

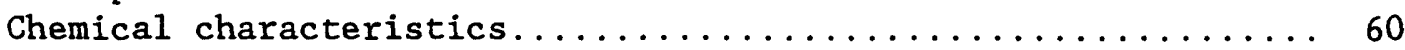

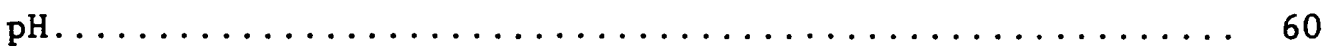

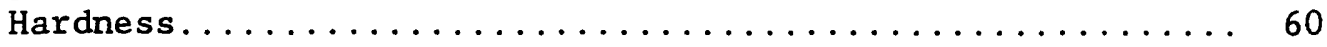

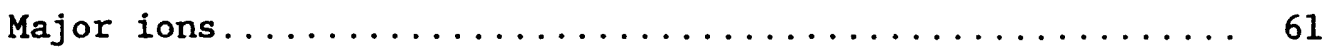

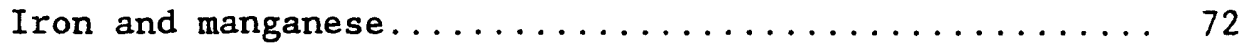

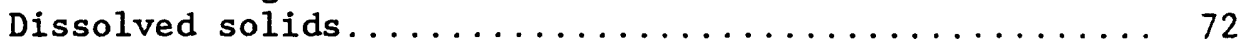

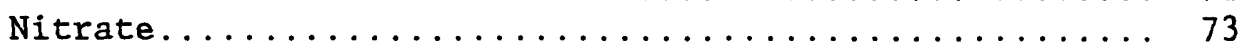

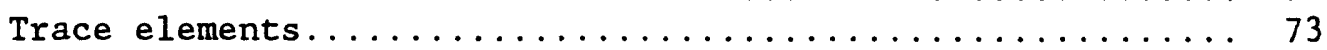

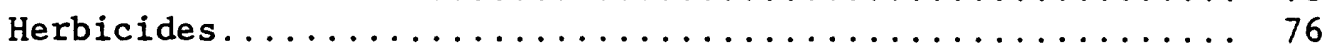

Problems related to ground-water quality.............. 77

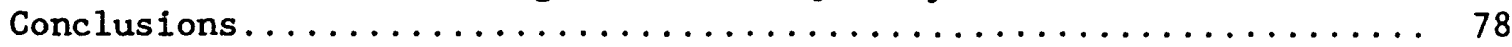

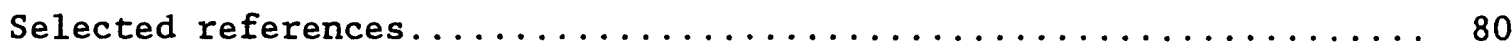

Glossary................................ 88 


\section{ILLUSTRATIONS}

\section{Plates}

[The plates are not included with this report but are on file in the U.S. Geological Survey, Pennsylvania District Library.]

Plate 1.--Hydrogeologic map of the Cambrian and Ordovician carbonate rocks in the Valley and Ridge physiographic province, Pennsylvania (northern Sheet)

2.--Hydrogeologic map of the Cambrian and Ordovician carbonate rocks in the valley and Ridge physiographic province, Pennsylvania (southern Sheet)

\section{Figures}

Figure 1.--Location of the valleys underlain by Cambrian and ordovician carbonate valleys in

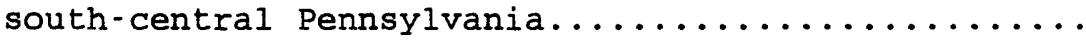

2.--Withdrawals of water by source and use category in the Cambrian and Ordovician carbonate valleys of south-central Pennsylvania................. 6

3.- -Withdrawals of ground water by valley and

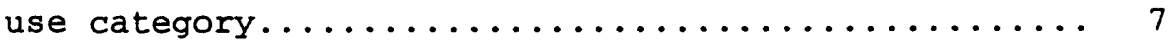

4.--Hydrograph of well Ce 118 in the Gatesburg Formation and daily precipitation at state College, Pennsylvania....................... 26

5. - Hydrograph of well Ce 636 in the undivided Coburn through Nealmont Formations and daily precipitation at State College, Pennsylvania............. 27

6.--Hydrograph of well Bd 508 in the undivided Nittany and Larke Formations and daily precipitation at Martinsburg, Pennsylvania................. 29

7.--Hydrograph of well Ce 580 in the Gatesburg Formation and daily precipitation at state College,

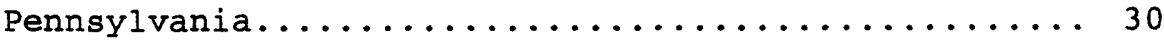

8.--Upstream view of Sinking Run about 1,500 feet downstream from Arch Spring in the Nittany Valley showing where water sinks into stream bed........ 31

9.--Monthly precipitation during water years 1984-85 at Milroy, Pennsylvania, and average monthly precipitation from $1941-70 \ldots \ldots \ldots \ldots \ldots \ldots \ldots \ldots$

10.--Monthly precipitation during water years 1984-85 at State College, Pennsylvania and average monthly

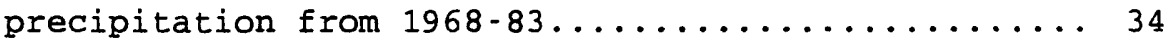

11.--Discharge of Kishacoquillas Creek at Reedsville,

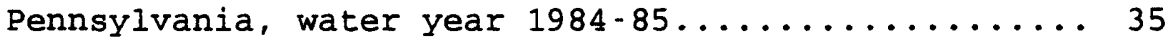

12.--Discharge of Spring Creek at Milesburg, Pennsylvania,

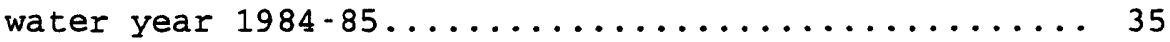

13.--Water levels in wells Mf 344 and Mf $367 \ldots \ldots \ldots \ldots \ldots 37$

14.--Distribution of water-bearing zones in the Coburn through Loysburg Formations............... 40

15.--Distribution of water-bearing zones in the Bellefonte

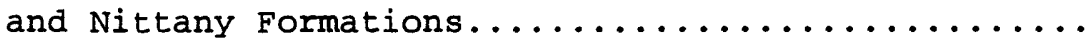




\section{ILLUSTRATIONS - - Continued}

Figure 16.--Distribution of water-bearing zones in the Bellefonte and Axemann Formations, Nittany and Larke Formations, and Warrior Formation.................... 42

17.--Distribution of water-bearing zones in the Axemann and Stonehenge Formations................. 43

18.--Distribution of water-bearing zones in the Gatesburg Formation......................... 44

19. - Quartile values of well depths, plotted by geologic unit........................... 45

20.--Quartile values of casing depths in wells, plotted by geologic unit.................... 46

21.--Quartile values of the depth to water in wells, plotted by geologic unit................ 47

22. - Quartile values of the specific capacities of lowproduction-use wells, plotted by geologic unit...... 49

22a. -Quartile values of the specific capacities of highproduction-use wells, plotted by geologic unit...... 50

23. - -Water levels in wells $\mathrm{Ba} 329$ in the Gatesburg Formation and $\mathrm{Ba} 369$ in the undivided Nittany and Larke Formations and precipitation at Martinsburg, Pennsylvania, October 1983 to November $1984 \ldots \ldots \ldots . \ldots 58$

24.--Quartile values of hardness as $\mathrm{CaCO}_{3}$ in wells, plotted by geologic unit................. 62

25. - Quartile values of hardness as $\mathrm{CaCO}_{3}$ in wells, plotted by valley.

TABLES

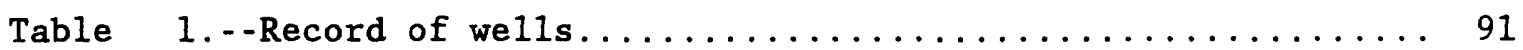

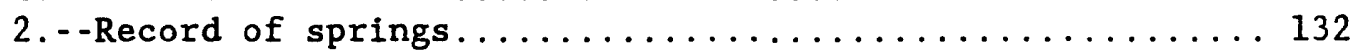

3.--Stratigraphy and distribution of mapped geologic units in valleys........................ 10

4. - -Water budgets for representative ground-water basins... 32

5.--Comparison between high- and low-production-use wells... 51

6.--Calculated sustained yields of wells in selected geologic units...................... 52

7.--Summary of hydraulic properties and theoretical drawdowns typical of the aquifers after 180 days

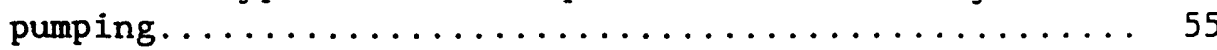

8.--Chemical analyses of major constituents in well and

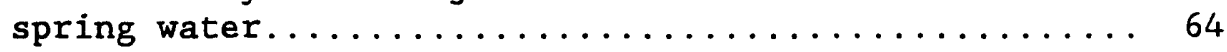

9. - - Summary of statistics on the concentrations of major chemical constituents in water from selected geologic units...................... 70

10.--Chemical analyses of trace metals in well and spring

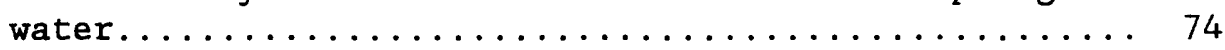

11.--Chemical analyses of pesticides in well and spring

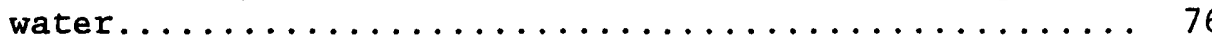




\section{CONVERSION FACTORS AND ABBREVIATIONS}

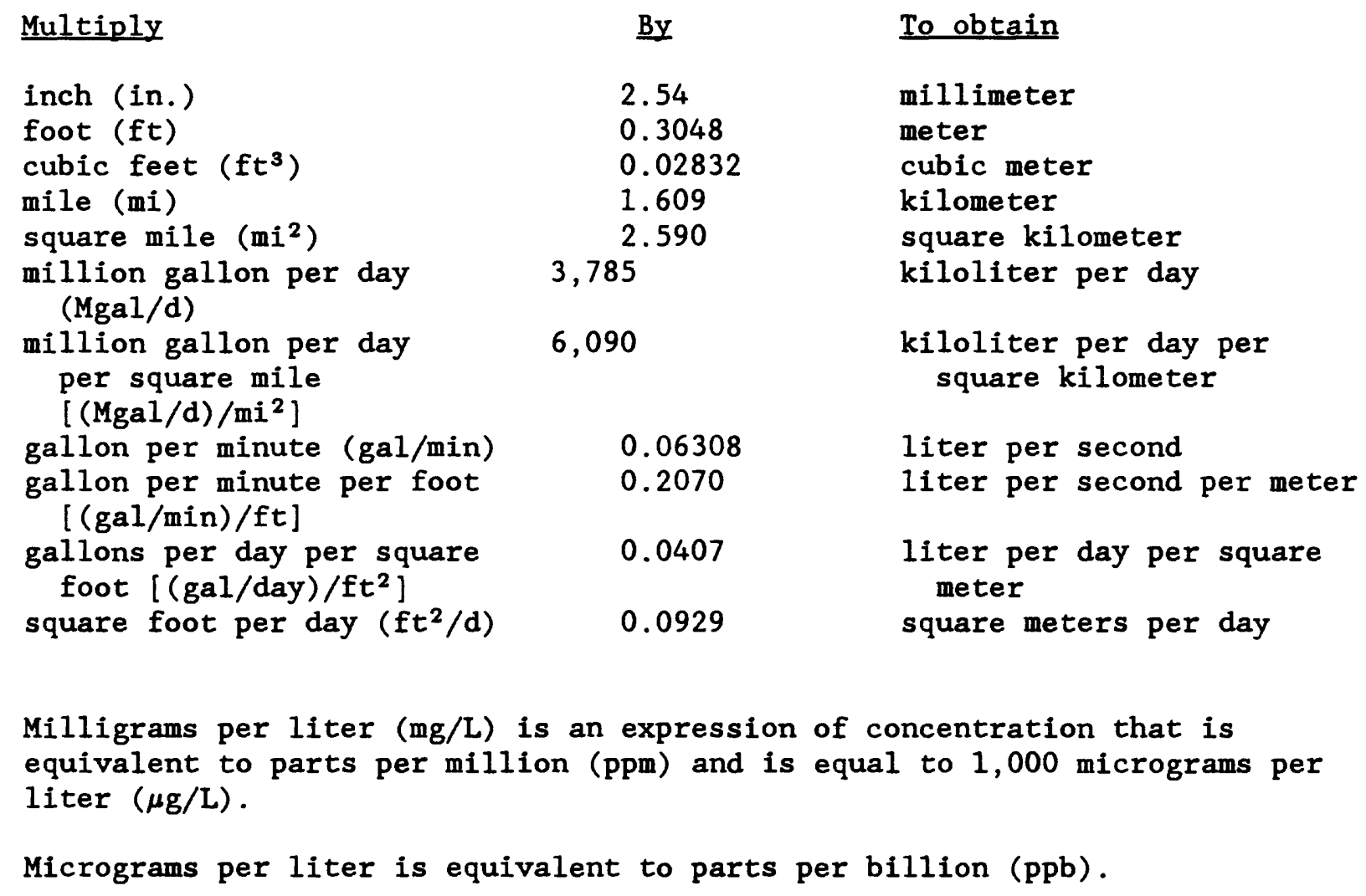


GROUND-WATER RESOURCES OF CAMBRIAN AND ORDOVICIAN CARBONATE ROCKS IN THE VALLEY AND RIDGE PHYSIOGRAPHIC PROVINCE OF PENNSYLVANIA

By Albert E. Becher

\section{ABSTRACT}

Ground water is a vital resource for the 150,000 people living in 10 separate or contiguous valleys of Bedford, Blair, Centre, Clinton, Fulton, Huntingdon, and Mifflin Counties. These valleys have formed on anticlinal folds in a sequence of Cambrian and Ordovician carbonate strata that exceed 8,000 feet in thickness. Younger clastic strata conformably overlie the carbonate rocks and form ridges along the valley perimeters, which rise 700 to 1,500 feet above the valley floors.

About $43 \mathrm{Mgal} / \mathrm{d}$ (million gallons per day) of water is withdrawn for use in all the valleys; 90 percent is derived from ground-water sources. Nearly 75 percent of the water is used in the two largest valleys, 49 percent in the Nittany Valley, and another 25 percent in the Morrison Cove and Canoe Valleys.

Single wells can produce about $1,000 \mathrm{gal} / \mathrm{min}$ (gallons per minute) from the Gatesburg and Nittany Formations; $500 \mathrm{gal} / \mathrm{min}$ from the Bellefonte and Axemann Formations; at least $100 \mathrm{gal} / \mathrm{min}$ from the undivided Benner through Loysburg, undivided Coburn through Loysburg, undivided Bellefonte and Axemann, undivided Nittany and Larke, Warrior, and Stonehenge Formations; and 50 gallons per minute from the Rockdale Run, Shadygrove, and undivided Coburn through Nealmont Formations. Wells in valleys have the greatest potential yield and wells on hilltops the least. Other topographic positions have intermediate yield potentials. Ideally sited wells, such as those on fracture traces, have greater yields than do randomly sited wells. Local cave-passage orientation correlates with local joint orientation maxima, which correlates with local fracture-trace orientation. These relations can aid in the selection of sites for large production wells.

Recharge to the carbonate aquifers is from precipitation directly on the land surface and indirectly from runoff draining mountain slopes. In the latter case, about 80 percent of runoff from mountain slopes infiltrates the colluvium or enters sinkholes in stream channels along the valley perimeters. An estimated 75 percent of the runoff that infiltrates flows through conduits formed in the limestone immediately adjacent to the mountain flanks and discharges as springs a short distance downvalley. Discharges from these springs fluctuate greatly and some springs may be dry during periods of baseflow. Of 42 large perennial springs in the valleys, 26 have flows greater than $1,000 \mathrm{gal} / \mathrm{min}$, and 3 have flows greater than $10,000 \mathrm{gal} / \mathrm{min}$ some of the time. 
Annual precipitation in the Kishacoquillas and Spring Creek basins averages about 38 and 39 inches, respectively. About 21 inches is lost farrm each basin to evapotranspiration. Another 13 inches leaves the Kishacoquillas basin and 16 inches leaves the Spring Creek basin as ground-water discharge. The remaining water leaves as direct runoff. Water, in amounts equivalent to ground-water discharge, recharge the ground-water system and are available for use. Expressed volumetrically over the basin areas, $0.62\left[(\mathrm{Mgal} / \mathrm{d}) / \mathrm{mi}^{2}\right]$ (million gallons per day per square mile) is available for use in the Kishacoquillas basin and $0.80\left[(\mathrm{Mgal} / \mathrm{d}) / \mathrm{mi}^{2}\right]$ is available for use in the Spring Creek basin. During drought years, only 0.34 and $0.45\left[(\mathrm{Mgal} / \mathrm{d}) / \mathrm{mi}^{2}\right]$ are available in the Kishacoquillas and Spring Creek basins, respectively. The Sugar, Brush, Penns, and Big Cove Creek Valleys have similar hydrogeologic settings to the Kishacoquillas Creek basin; the Nittany, Morrison Cove, Canoe, and Snake Spring Valleys have similar hydrogeologic settings to the Spring Creek basin. Similar hydrogeologic settings will have similar amounts of ground water available for use.

Estimates of transmissivity, based on median specific capacity, range from $15 \mathrm{ft}^{2} / \mathrm{d}$ (feet squared per day) for the Coburn through Nealmont Formations to 5,200 $\mathrm{ft}^{2} / \mathrm{d}$ for the Nittany Formation. Transmissivities determined from pumping test data range from $560 \mathrm{ft}^{2} / \mathrm{d}$ for the Benner through Loysburg Formations to $120,000 \mathrm{ft}^{2} / \mathrm{d}$ for the Nittany Formation. The specific yield of the carbonate rocks, based on water table declines during baseflow in the Kishacoquillas and Spring Creek basins, is 0.015 . Interference is likely between pumped wells spaced as much as 1,000 feet apart and is greatest parallel to the dominant local fracture systems.

Ground-water quality is suitable for drinking and most other uses, but is hard. Iron and manganese concentrations slightly exceed the respective 0.3 and 0.5 milligram per liter, the U.S. Environmental Protection Agency maximum contaminant level (MCL) for potable water in less than 10 percent of the wells sampled. Nitrate concentrations exceed the MCL of 10 milligrams per liter (as nitrogen) in 17 of 146 wells sampled. Median concentrations of nitrate, as nitrogen, range from 3.3 milligrams per liter in the Northern Nittany and Penns, Sugar, and Brush Valleys to 5.9 milligrams per liter in the Kishacoquillas Valley. Herbicides at concentrations less than proposed MCLs, were found in 10 of 20 wells and springs sampled, but only in one sample at a greater concentration of 20 micrograms per liter.

Noticeable effects of withdrawals on water levels were noted in the vicinity of State College where an average of $8.1 \mathrm{Mgal} / \mathrm{d}$ is pumped from public supply wells and from quarries for purposes of dewatering. Although adequate amounts of potable water are available to meet current demands, monitoring of water levels is needed to manage over droughts.

The most widespread and growing water-quality problem is an increase in the amount of nitrate that enters the ground water from agricultural practices. A related potential problem results from the application of herbicides to farmland. At least nine sites that were contaminated by petroleum and other toxic chemical leaks and spills had been discovered, were undergoing cleanup, or were being monitored from 1983-86. 


\section{INTRODUCTION}

\section{Background}

Ground water is vital to the residents of Pennsylvania. It is used for domestic, public, commercial, and industrial supply; and, in rural areas, is the only economical source available for water supply. Ground water also sustains streamflow during dry periods. A continuing cooperative program between the Pennsylvania Department of Environmental Resources (PaDER), Bureau of Topographic and Geologic Survey and the U.S. Geological Survey develops information that describes the ground-water resources of selected areas. The information gathered and interpreted is published in reports for use by state and municipal planners, consultants, and others interested in the quantity and quality of water in Pennsylvania.

\section{Purpose and Scope}

This report describes the occurrence, movement, quantity and availability, and quality of ground water in the Cambrian and Ordovician carbonate rocks of the Appalachian Mountain Section of the Valley and Ridge physiographic province. The study encompasses the 10 separate or contiguous valleys in 7 counties of central Pennsylvania (fig. 1).

The scope of work included original field inventory to establish a network of wells in which to make synchronous water-level measurements needed to prepare water-table maps, and in conjunction with existing stream gages, calculate aquifer storage and define water budgets. Well construction characteristics and yielding ability were determined from statistical analysis of data collected during this study and earlier studies (Taylor and others, 1982, 1985) (Wood, 1980) using the univariate procedure of the Statistical Analysis System (Council, K.A. 1979). Analyses by PaDER of about 150 water samples collected by U.S. Geological Survey personnel from selected wells and springs, provided data for determining the general ground-water quality and the extent of contamination, especially by nitrates. Some well inventory data and water-quality analyses from earlier reports are included in the data tables of this report and are used with new data for analysis and interpretation. Streamflow and water-level data were collected for Kishacoquillas and Spring Creeks and used with precipitation data from the U.S. Department of Commerce stations at State College, Milroy, and Lewistown for water budget and specific yield calculations. 


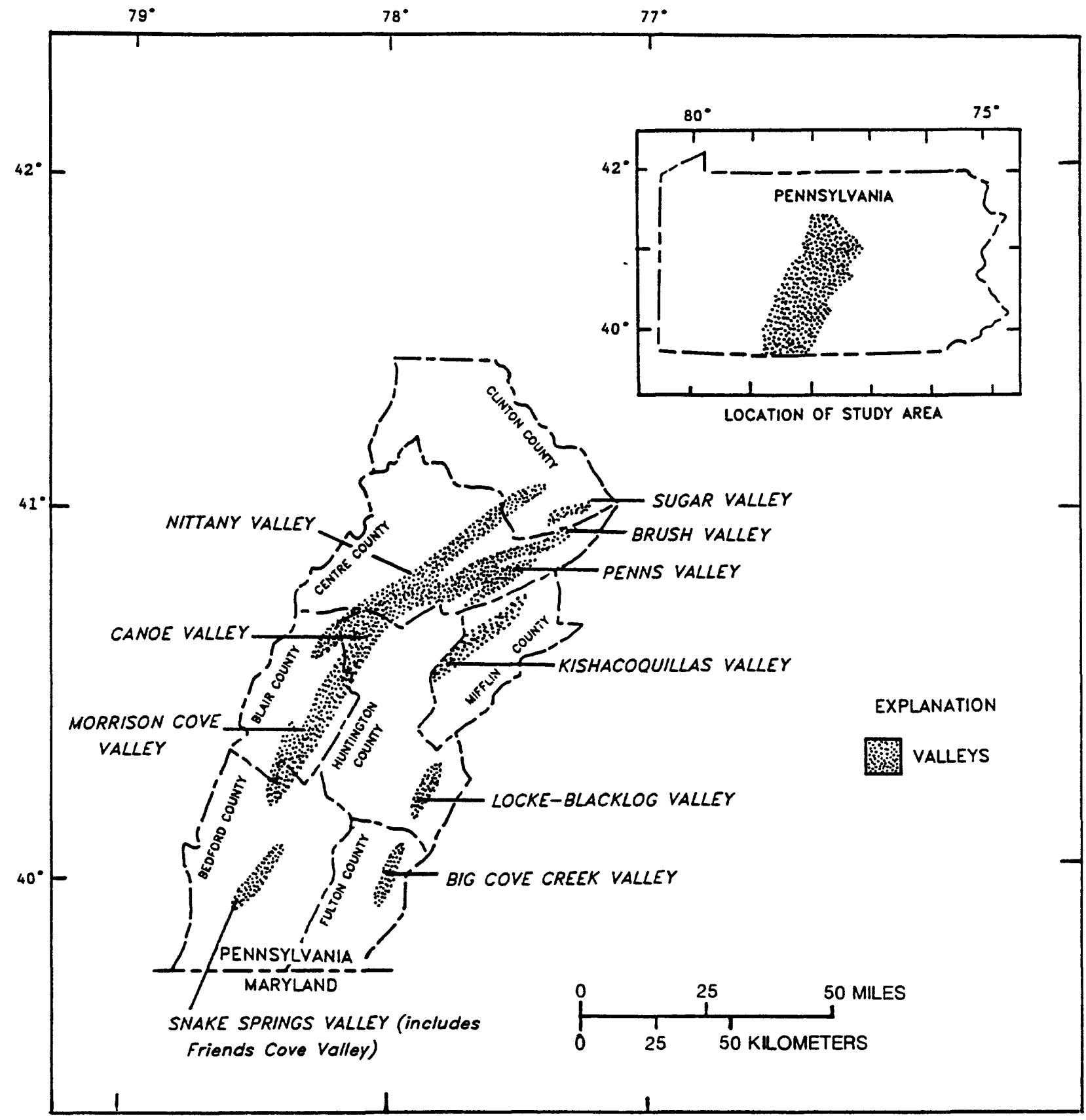

Figure 1.-Location of the valleys underlain by Cambrian and Ordovician carbonate valleys in south-central Pennsylvania. 


\section{Description of Study Area}

\section{Location and Physiographic Setting}

The 10 valleys studied extend northeast, from the southern border of Pennsylvania, within the belt of alternating valleys and ridges that form the northern termination of the Appalachian Mountains (fig. 1). All of the valleys are elongate and range from about $15 \mathrm{mi}$ (miles) (Locke-Blacklog Valley) to $60 \mathrm{mi}$ (Nittany Valley) in length. The boundaries between named valleys that are connected are undefined and the names only reflect the geographic nomenclature of U.S. Geological Survey topographic quadrangle maps.

Steep, forested ridges reaching heights ranging from $700 \mathrm{ft}$ to $1,500 \mathrm{ft}$ (feet) above the valley floor, bound the valleys. Valley floors (feet) are ft above the valley floor, bound the valleys. Valley floors are undulating, in general, but broad, low ridges, underlain by a thick residuum, rise 300 to 500 $\mathrm{ft}$ in the middle of the westernmost valleys (Nittany, Snake Spring, Morrison Cove, and Canoe). Narrower dissected linear ridges, having 30 to $50 \mathrm{ft}$ of relief, underlie the more weather-resistant dolomite formations in some valleys. The land surface area encompassed by all the valleys totals more than $700 \mathrm{mi}^{2}$ (square miles).

\section{Geologic Setting}

The valleys have developed on a folded sequence of Cambrian and Ordovician age limestone and dolomite formations that total over 8,000 ft in thickness. Shale of the Reedsville Formation stratigraphically overlies the carbonate rock sequence and generally crops out on the flanks of the adjacent quartzite and sandstone ridges, but is eroded from central parts of most valleys. These rocks were formed from sediments deposited under near-shore marine conditions over a 90 million year time span beginning about 520 million years ago.

Each valley occurs in the central part of an anticlinal fold that commonly is overturned slightly to the northwest. Smaller folds, thrust faults and extension faults modify the basic structural framework in parts of some valleys.

\section{Population and Water Use}

Between 1960 and 1980 the population of the valleys increased by an average of 29 percent and now totals more than 150,000 people. Although most of the population increase was in the vicinity of the Borough of State College in the Nittany Valley, the population in all other valleys also grew at rates ranging from 11 to 34 percent. Water use grew at least at these rates and probably at higher rates because of the general increase in per capita water use over this period of time. 
Annual withdrawal of water from all ten valley averaged about $43 \mathrm{Mgal} / \mathrm{d}$ during recent years ( $T$. Denslinger, Pennsylvania Department of Environmental Resources, written commun., 1985). More than $38 \mathrm{Mgal} / \mathrm{d}$, or 90 percent, was derived from ground water sources. A summary of withdrawals by major wateruse categories, excluding irrigation, is shown in figure 2. Withdrawals for irrigation are small, $0.3 \mathrm{Mgal} / \mathrm{d}$, and are derived mostly from ponds and streams. Irrigation varies greatly from year to year depending on the amounts and timing of precipitation during the growing season and economic factors. Consumptive use in all categories is estimated at more than $8 \mathrm{Mgal} / \mathrm{d}$.

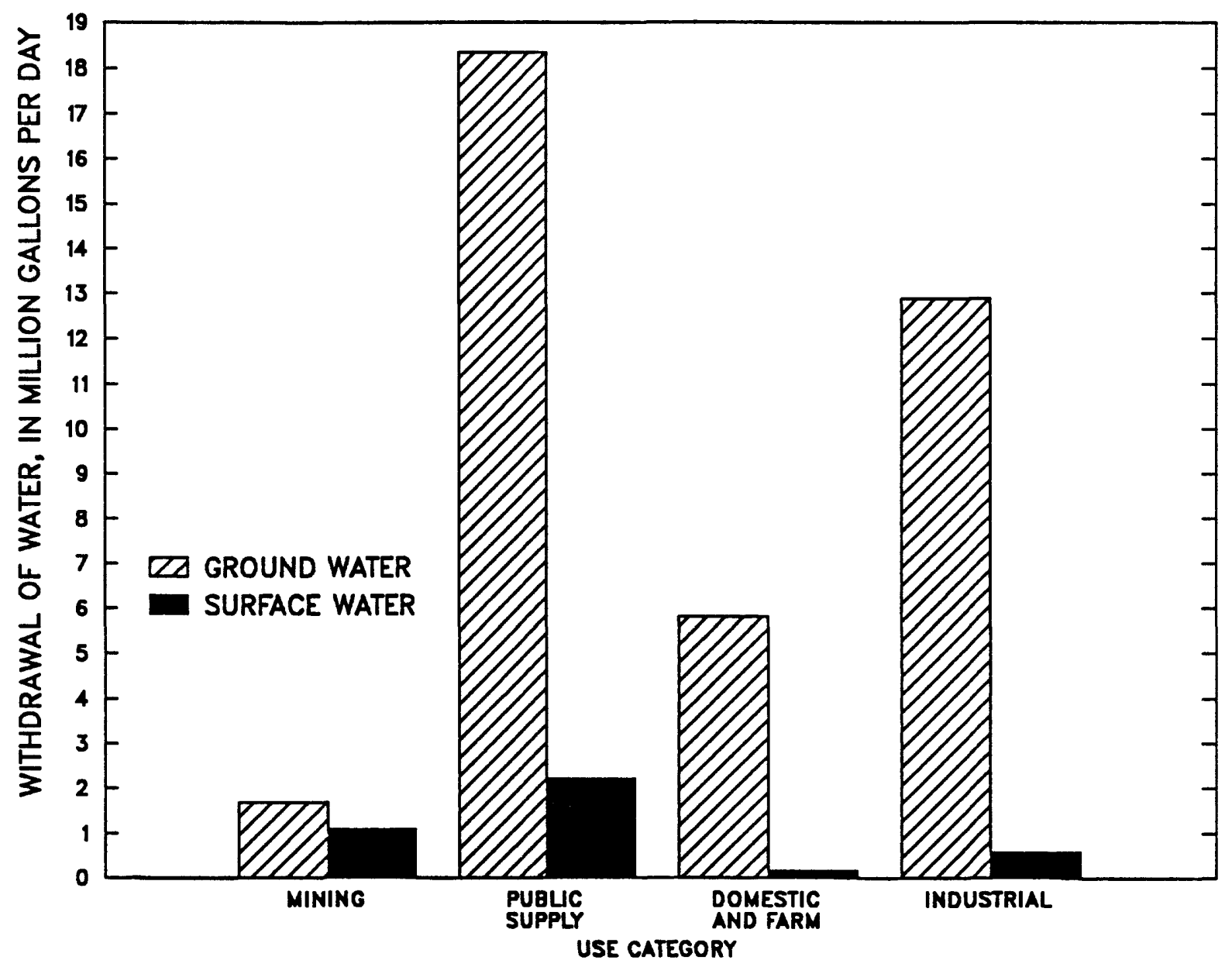

Figure 2.-Withdrawals of water by source and use category in the Cambrian and Ordovician carbonate valleys of south-central Pennsylvania. 
Ground water withdrawal in each of the valleys is shown by use category in figure 3. Penns, Brush, and Sugar Valleys were combined because they have similar geology and land use and are connected geographically. In LockeBlacklog Valley, less than $0.02 \mathrm{Mgal} / \mathrm{d}$ of water is withdrawn, all of it for domestic and farm purposes. Most of the water withdrawn is in the two largest valleys, 49 percent in the Nittany Valley and 25 percent in Morrison Cove and Canoe Valley.

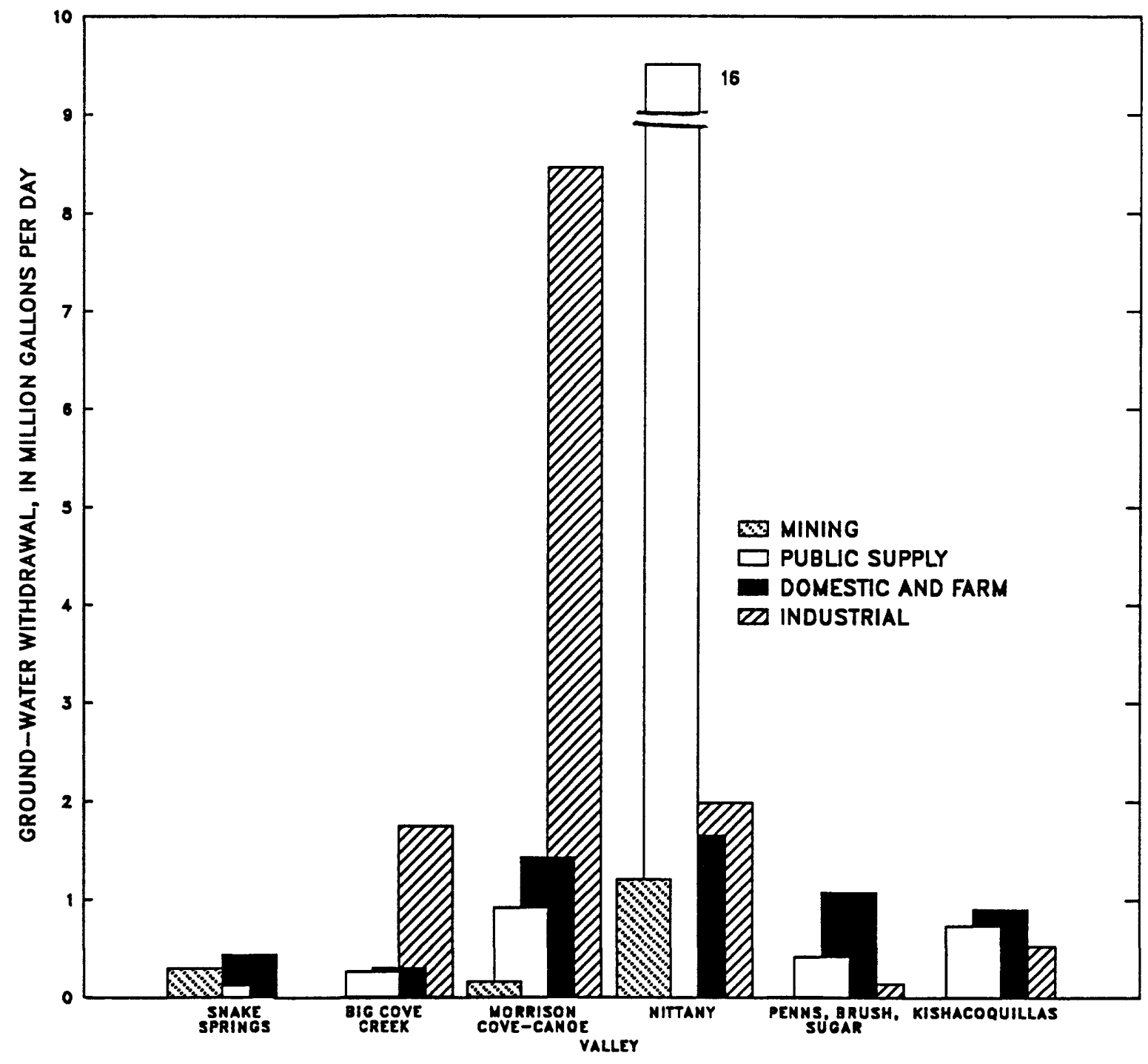

Figure 3.-Withdrawals of ground water by valley and use category. 


\section{Acknowledgments}

The names of the many homeowners, organizations, institutions, municipalities, and companies who kindly allowed us access to their wells and property for the collection of the data essential to this study are given in the records of wells (table 1, at back of report) and springs (table 2, at back of report). We wish to offer special thanks to the Borough of Martinsburg and the Pennsylvania State University for their cooperation and help. John Kastrinos, while a graduate student at Pennsylvania State University, completed much of the well inventory in the Nittany, Penns, Brush, and Sugar Valleys. Information and reports provided by the Union Township Municipal Authority, Walker Township Water Association, Laurel Pipeline Company, Pennsylvania Electric Company, The Gulf $0 i 1$ Company, Todd Giddings and Associates, Martin Associates, R.E. Wright Associates, and Moody and Associates were also helpful to the study. Edward Pinto, a graduate student at Shippensburg State University, compiled geologic information for the study, calculated the data on caves, and prepared many of the tables and illustrations in the report. 
The stratigraphic sequence of geologic units discussed below and shown on the geologic maps (plates 1 and $2^{1}$ ) are based on the Atlas of Preliminary Geologic Quadrangle Maps of Pennsylvania (Berg and Dodge, 1981). Some of the geologic formations are grouped with other formations into one unit on the maps. The geology of each of these formations is described separately, but the water-bearing and water-quality properties are discussed for the combined unit unless the formation is mapped both separately and with other units on one or both geologic maps. Properties for the combined units then are discussed and, if the data permit, each formation also is discussed separately. The geologic units used in this report and how they are combined and shown on plates 1 and $2^{1}$ for each valley are given in table 3 . Actual stratigraphic relationships between geologic units are shown in the correlation of map units on plates 1 and $2^{1}$.

Reedsville Formation

\section{Description}

The Reedsville Formation, the uppermost Ordovician unit, is a medium dark-gray to brownish- or greenish-gray shale with some interbedded siltstone and sandstone beds. Commonly the shale is fissile but may be thick bedded also. A black calcareous shale at the base of the formation grades into the underlying carbonate rocks and, where prominent, has been named the Antes Formation. This formation commonly crops out on the flanks of the ridges that border the carbonate-rock valleys.

\section{Water-bearing properties}

This formation was not a part of the study. However, data were obtained on 28 wells inventoried for water levels. The median specific capacity and reported yield are $0.4[(\mathrm{gal} / \mathrm{min}) / \mathrm{ft}]$ of drawdown and $20 \mathrm{gal} / \mathrm{min}$, respectively.

\section{Water quality}

No samples were collected for chemical analysis from the Reedsville Formation for this study. However, recent analytical results from several other studies (Taylor and others, 1982, 1983) indicate the water is moderately hard to hard with low to moderate dissolved solids content. Excessive amounts of iron, manganese, and hydrogen sulfide are common.

\section{Sumary evaluation}

Low-production uses are readily supplied by shallow wells in the Reedsville Formation.

1 Plates are on file in the U.S. Geological Survey, Pennsylvania District Library . 
Table 3.--Stratigraphy and distribution of mapped geologic units in valleys (Arrows extend across more than one formation where the

included formations are mapped as one unit.)

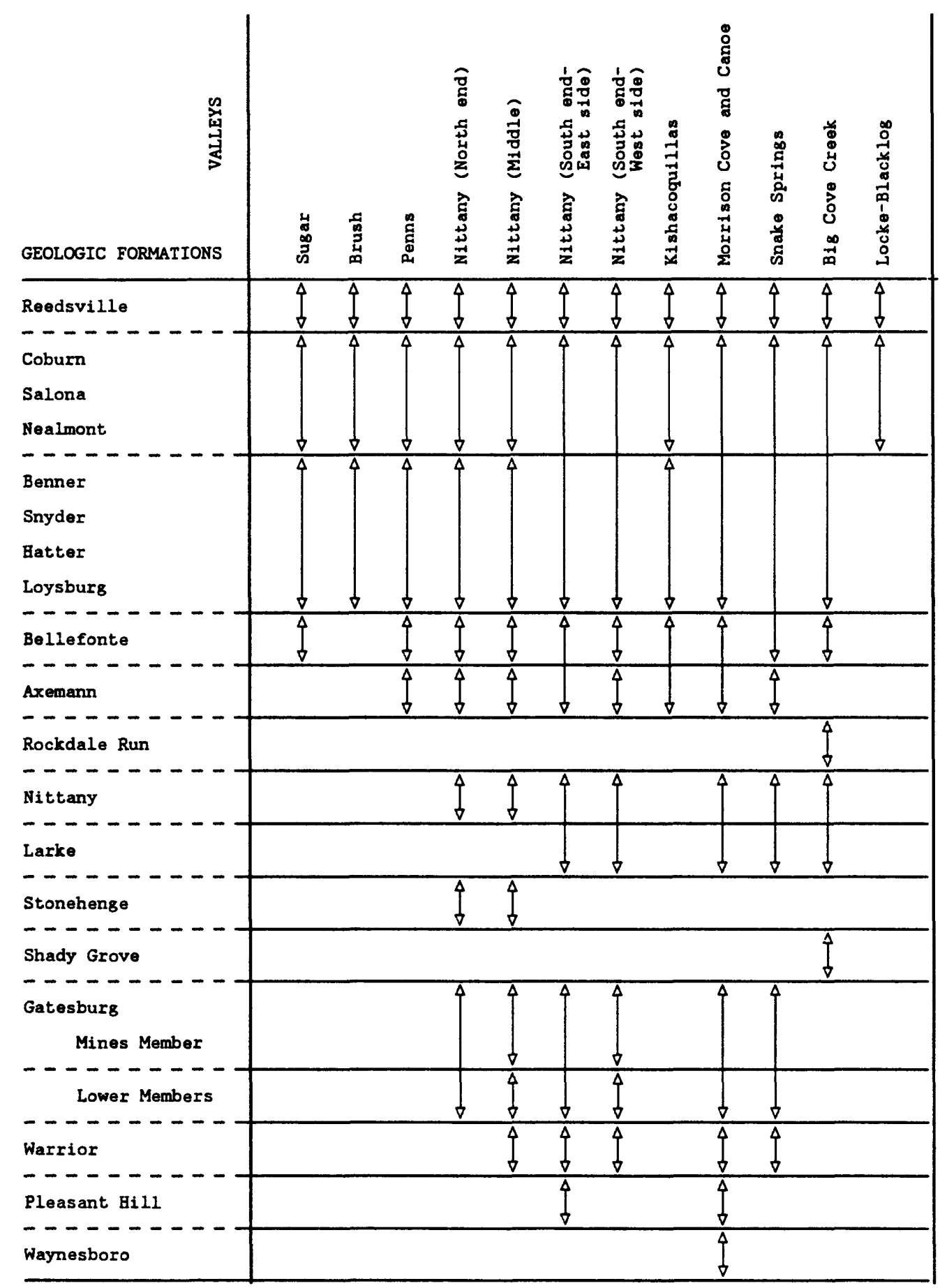


Coburn, Salona, and Nealmont Formations, Undivided

\section{Description}

The Coburn Formation is a medium and medium- to very dark-gray, thinbedded, argillaceous, and fossiliferous limestone containing interbeds of calcareous shale. It attains a maximum thickness of $325 \mathrm{ft}$ at Bellefonte in the Nittany Valley.

The Salona Formation is a very dark-gray to black, medium- to coarsegrained, sparsely fossiliferous limestone with some shale partings. It is about $170 \mathrm{ft}$ thick.

A 30- to 75-ft thick medium- to dark-gray unit called the Nealmont Formation underlies the Salona. It consists of the Rodman and Centre Hall members. The Rodman, the upper member, is medium-to dark-gray, coarsely crystalline, and contains abundant crinoid and bryozoan fossils. The Centre $\mathrm{Hall}$ is medium- to dark-gray and finely crystalline limestone. A break in deposition occurred between deposition of the Nealmont Formation and the underlying Benner Formation. These formations commonly outcrop adjacent to the noncarbonate rocks on the ridge flanks.

\section{Water-bearing properties}

Unbuffered, slightly acidic runoff from the mountain ridges commonly reaches the outcrop area of these thin formations before any other carbonate rocks in the valleys. Therefore, these formations have the greatest potential for solution of carbonate minerals. Major contrasts between lithologies in adjacent beds of these formations cause differences in their relative solubilities (Rauch, 1972). Sinkholes, large conduit passages, and caves are well developed in the more soluble beds. Most runoff from the mountains drains into sinkholes, flows through conduits, and discharges within hours or days to streams (Konikow, 1969). Once conduit passages exist they are the preferred paths of flow and further enlargement rather than small fractures. The openings available to most wells, however, are small fractures and solution openings that have retained recharge in storage for much longer periods.

The median specific capacities of wells constructed for low-production uses (29 wells) and for high-production uses ( 4 wells) are 0.08 [(gal/min)/ft] and 0.12 [(gal/min)/ft], respectively. The median reported yields for 55 wells of low-production use and 11 wells developed for high-production use are $10 \mathrm{gal} / \mathrm{min}$ and $12 \mathrm{gal} / \mathrm{min}$, respectively. A maximum yield of $90 \mathrm{gal} / \mathrm{min}$ and a maximum specific capacity of 2 [(gal/min)/ft] were determined from the well data for these formations. About 25 percent of all wells in these formations yield $5 \mathrm{gal} / \mathrm{min}$ or less. Variability in the well yield and specific capacity statistics among different valleys is negligible. Five of the 42 large springs shown in the record of springs (table 2) yield from these formations. 


\section{Water quality}

Water from these formations is hard to very hard (median hardness 205 $\mathrm{mg} / \mathrm{L}$ as $\left.\mathrm{CaCO}_{3}\right)$. The median of specific conductance measurements of well water is $520 \mu \mathrm{S} / \mathrm{cm}$ (microsiemens per centimeter at 25 degrees Celsius) and the median $\mathrm{pH}$ measurement is 7.3 .

\section{Summary evaluation}

These formations can supply adequate amounts of water for low-production use. Development of supplies of water for high-production use is possible from some springs and from wells that intercept large conduits below the zone of water-table fluctuation. The water will likely be hard.

Benner, Snyder, Hatter, and Loysburg Formations, Undivided

\section{Description}

The Benner Formation consists of light- to dark-gray, mostly fissile to flaggy and thick-bedded, very-finely to finely crystalline limestone. Two members are recognized in the Benner--the high calcium limestone Valentine Member, at the top, and the underlying argillaceous Valley View Member that contains interbedded metabentonite beds. The combined thickness of these members is about $150 \mathrm{ft}$.

Below and in gradational contact with the Benner is the Snyder Formation, an 80-ft thick, medium- to dark-gray, coarsely crystalline limestone and limestone conglomerate containing interbeds of finely crystalline dolomitic limestone. Laminated, mud-cracked and ripplemarked beds commonly are present.

The Hatter Formation underlies the Snyder. It is a medium- to dark-gray, fine-grained, argillaceous, laminated, dolomitic and oolitic limestone that is about $75 \mathrm{ft}$ thick. The Hatter unconformably overlies the underlying Loysburg Formation.

The Loysburg Formation consists of light- to medium-gray, medium- to thick-bedded, fine-grained, shaly limestone in the upper Clover Member and dark gray dolomite and dolomitic limestone in the lower Milroy Member. Both members vary in thickness but have an average combined thickness of about 150 ft.

\section{Water-bearing properties}

Hydrogeologic conditions in these formations are similar to those in the overlying Coburn, Salona, and Nealmont Formations with one exception. These formations crop out in more central parts of the valley, especially in Penns, Sugar, and Brush Valleys. Inflow from the adjacent ridges, therefore, is not channeled directly into large conduits, and recharge spreads more evenly through the existing fracture openings. A comparison of the specific capacities and reported yields shown below with those shown for the overlying units clearly shows the importance of this hydrogeologic difference. 
The median specific capacity for 15 low-production-use wells is 0.33 [(gal/min)/ft] and for 4 high-production-use wells is 17 [(gal/min)/ft] . Median reported yields of 36 low-production-use and 9 high-production-use wells are 22 and $60 \mathrm{gal} / \mathrm{min}$, respectively. The maximum well yield reported is $350 \mathrm{gal} / \mathrm{min}$. About 10 percent of the wells yield $5 \mathrm{gal} / \mathrm{min}$ or less. Four large springs of the 42 listed in the Record of Springs (table 2) discharge from these formations.

\section{Water quality}

Water is hard to very hard (median hardness $205 \mathrm{mg} / \mathrm{L}$ as $\mathrm{CaCO}_{3}$ ). The median specific conductance is $565 \mu \mathrm{S} / \mathrm{cm}$ and the median $\mathrm{pH}$ is 7.3 . Iron and manganese in three of 21 wells sampled exceeded the secondary maximum contaminant leve1 (SMCL) recommended by the U.S. Environmenta1 Protection Agency (USEPA) (1986b) of $300 \mu \mathrm{g} / \mathrm{L}$ (micrograms per liter) for iron and $50 \mu \mathrm{g} / \mathrm{L}$ for manganese. Concentrations in two samples exceeded the MCL for nitrate (U.S. Environmental Protection Agency, 1986a) of $10 \mathrm{mg} / \mathrm{L}$ and the SMCL of 500 $\mathrm{mg} / \mathrm{L}$ for total dissolved solids (U.S. Environmental Protection Agency, 1986b).

\section{Summary evaluation}

Supplies of hard water are readily available for low-production use from wells in these formations. Supplies for high-production use are available from some springs and from wells that intercept cavity systems below the zone of water-table fluctuation.

Coburn through Loysburg Formations, Undivided

\section{Description}

Formations in the stratigraphic interval between the top of the Coburn and the base of the Loysburg Formations are mapped as one unit in the southern part of the Nittany Valley and in all the valleys farther to the south. Lithologic characteristics are similar to the equivalent units described.

\section{Water-bearing properties}

Statistical values of the water-bearing properties for the undivided rocks, fall between the upper and lower statistical values of the separate rock units, as would be expected. For low-production uses, the median specific capacity of 16 wells and median reported yield of 43 wells are 0.17 [(gal/min)/ft] and $8 \mathrm{gal} / \mathrm{min}$, respectively. The median reported yield of $\mathrm{six}$ high-production-wells is $30 \mathrm{gal} / \mathrm{min}$. The maximum specific capacity measured is 2.3 [(gal/min)/ft] and the maximum yield reported is $100 \mathrm{gal} / \mathrm{min}$. One of the large springs listed in table 2 discharges from this geologic unit. 


\title{
Water quality
}

Water from this stratigraphic interval is hard to very hard. A median hardness of $188 \mathrm{mg} / \mathrm{L}$ was determined for water from these rocks. The median $\mathrm{pH}$ and specific conductance of well water are 7.3 and $460 \mu \mathrm{S} / \mathrm{cm}$, respectively. One of the 10 samples analyzed exceeded the USEPA's SMCL for dissolved solids. Another sample exceeded the SMCL for iron, and two others exceeded the SMCL for nitrate.

\section{Summary Evaluation}

Yields of up to $100 \mathrm{gal} / \mathrm{min}$ of hard water are obtained from wells in these formations. Large solution cavity systems below the zone of water-table fluctuation, if intercepted by a well, could provide high-production-use supplies.

\author{
Bellefonte Formation
}

\section{Description}

The upper Tea Creek Member of the Bellefonte Formation is light- to medium-gray, very fine-grained dolomite. Medium-gray dolomite of the lower Coffee Run Member also contains sandstone beds and chert. The combined thickness of both members is about $1,400 \mathrm{ft}$.

\section{Water-bearing properties}

The median and maximum specific capacities of 32 low-production-use wells in the Bellefonte Formation are 0.20 and 17 [(gal/min)/ft], respectively. Similarly, the median and maximum reported yields for 77 low-production-use wells are 12 and $120 \mathrm{gal} / \mathrm{min}$. For high-production-use wells, the median specific capacity for 11 wells is $0.46[(\mathrm{gal} / \mathrm{min}) / \mathrm{ft}]$ and the maximum specific capacity is $20[(\mathrm{gal} / \mathrm{min}) / \mathrm{ft}]$. The median and maximum reported yields for high-production-use wells are 26 and $500 \mathrm{gal} / \mathrm{min}$, respectively. About 15 percent of all wells have yields reported to be less than $5 \mathrm{gal} / \mathrm{min}$. Eleven of the 42 large springs shown in table 2 discharge from the Bellefonte Formation.

\section{Water quality}

Water from the Bellefonte Formation is very hard. The median values of hardness, $\mathrm{pH}$, and specific conductance are $239 \mathrm{mg} / \mathrm{L}$ as $\mathrm{CaCO}_{3}, 7.3$, and 570 $\mu \mathrm{S} / \mathrm{cm}$, respectively. Three of 33 wells exceed the SMCL for iron, one of 30 for manganese, and five of 33 exceed the MCL for nitrate.

\section{Summary evaluation}

Yields in excess of $500 \mathrm{gal} / \mathrm{min}$ of potable water are possible from wells located at the most favorable sites in the Bellefonte Formation. 
Axemann Formation

\section{Description}

Light- to dark-gray, coarsely crystalline, fossiliferous limestone interbedded with silty, fine-grained limestone and silty, fine-grained dolomitic limestone characterize the Axemann Formation. Chert concretions and oolitic, conglomeratic limestone are also present. The Axemann averages about $500 \mathrm{ft}$ in thickness but ranges from 400 to $700 \mathrm{ft}$.

\section{Water-bearing properties}

The median and maximum specific capacities for data from seven lowproduction-use wells in the Axemann Formation are 0.93 and $16[(\mathrm{gal} / \mathrm{min}) / \mathrm{ft}]$. The median reported yield for 16 low-production-use wells is $20 \mathrm{gal} / \mathrm{min}$. The maximum reported well yield is $700 \mathrm{gal} / \mathrm{min}$ from a high-production-use well. Only one of 18 wells is reported to yield less than 5 gal/min.

\section{Water quality}

Water from wells in the Axemann Formation is very hard (median hardness, $257 \mathrm{mg} / \mathrm{L}$ as $\left(\mathrm{CaCO}_{3}\right)$. The median $\mathrm{pH}$ and specific conductance of water from wells in this formation are 7.5 and $619 \mu \mathrm{S} / \mathrm{cm}$, respectively.

\section{Summary evaluation}

Large supplies of very hard water can be obtained from favorably located wells in the Axemann Formation. A residential supply probably can be developed from any randomly located well.

$$
\text { Bellefonte, Axemann Formations, Undivided }
$$

\section{Description}

The Bellefonte and Axemann Formations are mapped as one unit in the Morrison Cove, Canoe, and Kishacoquillas Valleys, and in the southeastern end of the Nittany Valley. Descriptions of rocks are the same as for the separate formations.

\section{Water-bearing properties}

The median and maximum specific capacities of 14 low-production-use wells are 0.25 and $5.6[(\mathrm{gal} / \mathrm{min}) / \mathrm{ft}]$, respectively. The median and maximum reported yields for 45 low-production-use wells are 10 and $150 \mathrm{gal} / \mathrm{min}$, respectively. About 25 percent of all wells yield less than $5 \mathrm{gal} / \mathrm{min}$. Five of the 42 large springs 1isted in table 2 yield from this geologic unit. 
Water quality

Water from all wells is very hard. The calculated median values of hardness, $\mathrm{pH}$, and specific conductance are $239 \mathrm{mg} / \mathrm{L}$ as $\mathrm{CaCO}_{3}, 7.2$, and 605 $\mu \mathrm{S} / \mathrm{cm}$, respectively. Iron in water from one of 11 wells and manganese in water from one of 9 wells exceed the USEPA's SMCL.

\section{Summary evaluation}

Most wells provide adequate supplies of water for residential and other low-production-uses. Wells at favorable sites will yield $50 \mathrm{gal} / \mathrm{min}$ and may yield more than $500 \mathrm{gal} / \mathrm{min}$. Water is very hard.

Rockdale Run, Nittany, Nittany and Larke, and Stonehenge Formations

The Rockdale Run is the lateral equivalent of the lower part of the Bellefonte Formation and the Nittany and Axemann Formations in Big Cove Creek Valley. The Larke Formation is the lateral equivalent of the Stonehenge Formation, and is mapped with the overlying Nittany Formation to the south and west in the southern part of the Nittany Valley, the Snake Spring Valley, Morrison Cove and Canoe Valleys, and Big Cove Creek Valley.

\section{Rockdale Run Formation}

\section{Description}

Rocks of the Rockdale Run Formation are mostly light- to medium-gray, laminated, fine-grained limestone with some beds of dolomite near the top that contain small white chert rosettes. The lower part of the formation contains abundant brown, chert-bearing dolomite beds.

\section{Water-bearing properties}

Information is available from only two wells in this formation. Reported yields and specific capacities of these wells are 16 and $40 \mathrm{gal} / \mathrm{min}$ and 0.4 and 0.44 [(gal/min)/ft], respectively. Data from 41 wells in the Rockdale Run Formation in adjacent Franklin County have a median specific capacity of 0.6 [(gal/min)/ft]. About 25 percent of these wells yield less than $5 \mathrm{gal} / \mathrm{min}$.

\section{Water quality}

No water-quality information is available for this formation in the study area. In Franklin County, the water from this formation is very hard.

\section{Summary evaluation}

The Rockdale Run Formation should supply at least $50 \mathrm{gal} / \mathrm{min}$ of hard water to wells. 


\section{Description}

The Nittany Formation is composed of finely to coarsely crystalline, alternating 1ight-and dark-gray beds of dolomite that contains siliceous oolites and some sandy and cherty beds. The Nittany is about 1,200 ft thick.

\section{Water-bearing properties}

The median and maximum specific capacities of seven low-production-use we1ls in the Nittany are 0.6 and 160 [(gal/min)/ft], respectively. For 20 high-production-use wells, the median and maximum specific capacities are 33 and $600[(\mathrm{gal} / \mathrm{min}) / \mathrm{ft}]$, respectively. Eight of the 22 reported yields for high-production-use wells in the formation exceed $1,000 \mathrm{gal} / \mathrm{min}$. The median and maximum yields for the 22 high-production-use wells are $537 \mathrm{gal} / \mathrm{min}$ and $2,200 \mathrm{gal} / \mathrm{min}$, respectively. About 15 percent of all wells yield less than 5 gal/min. Four of the 42 large springs listed in table 2 discharge from the Nittany Formation.

\section{Water quality}

The median $\mathrm{pH}$, specific conductance, and hardness of water from wells are $7.4,610 \mu \mathrm{S} / \mathrm{cm}$, and $211 \mathrm{mg} / \mathrm{L}$ as $\mathrm{CaCO}_{3}$, respectively. Water from the Nittany Formation ranges from hard to very hard. Water analyzed from one of the ten wells sampled exceeds the USEPA's MCL for nitrate and the SMCL for total dissolved solids.

\section{Summary evaluation}

Yields in excess of $1,000 \mathrm{gal} / \mathrm{min}$ are obtained from wells that intercept large openings of interconnected fracture systems. Very hard, potable water is available from the Nittany Formation. 


\section{Description}

The Nittany Formation has been described previously. The Larke Formation is a dark-gray, coarsely crystalline dolomite containing fine-grained, laminated dolomite in the lower part, and some thick beds of fine-grained limestone. It is the stratigraphic equivalent of the Stonehenge Formation and is mapped with dolomites of the Nittany Formation in the Snake Spring, Morrison Cove and Canoe Valleys, and the southern tip of the Nittany Valley (Wagner, p. 19; Butts, 1939). The Larke Formation is about $250 \mathrm{ft}$ thick.

\section{Water-bearing properties}

The median and maximum specific capacities of 35 low-production-use wells in these combined formations are 0.27 and 74 [(gal/min)/ft], respectively. Similarly, the median and maximum reported yields of 81 low-production-use wells are 10 and $200 \mathrm{gal} / \mathrm{min}$, respectively. The reported yields of the two high-production-use wells are both $150 \mathrm{gal} / \mathrm{min}$. For about 20 percent of the wells, reported yields are less than $5 \mathrm{gal} / \mathrm{min}$.

\section{Water quality}

Well water has a median hardness of $214 \mathrm{mg} / \mathrm{L}$, as $\mathrm{CaCO}_{3}$, and is very hard. A median $\mathrm{pH}$ of 7.3 and a median specific conductance of $492 \mu \mathrm{S} / \mathrm{cm}$ was calculated for well water in this unit. Iron and dissolved solids concentrations in water from 2 of 17 wells and manganese concentrations in water from 5 of 14 wells exceed the USEPA's SMCLs for these constituents. Concentrations of these constituents in water from 3 of 17 wells exceed the MCL for nitrate.

\section{Summary evaluation}

Some wells yield more than 100 gal/min. Specific-capacity data suggest a few wells in very favorable locations can supply more than $1,000 \mathrm{gal} / \mathrm{min}$. Water from most wells is very hard. 
Stonehenge Formation

\section{Description}

The Stonehenge Formation is a medium- and dark-gray, finely crystalline limestone that contains thin laminae, bands, or up to 6-foot thick interbeds of dolomite. Thin, flat pebble conglomerate and flaggy beds characterize the lower part of the formation and chert nodules are present near the base. The thickness of this formation ranges from 250 to $600 \mathrm{ft}$.

\section{Water-bearing properties}

A median of $30 \mathrm{gal} / \mathrm{min}$ was calculated from reported yield data for 11 low-production-use wells. The maximum well yield reported is $100 \mathrm{gal} / \mathrm{min}$. All well yields reported exceed $5 \mathrm{gal} / \mathrm{min}$. Specific capacities of $0.39,0.49$ and $3.9[(\mathrm{gal} / \mathrm{min}) / \mathrm{ft}]$ were determined for the three wells.

\section{Water quality}

Water from the Stonehenge Formation is hard to very hard (median hardness $171 \mathrm{mg} / \mathrm{L}$ as $\mathrm{CaCO}_{3}$ ), has a median specific conductance of $339 \mu \mathrm{S} / \mathrm{cm}$, and a median $\mathrm{pH}$ of 7.5 .

\section{Summary evaluation}

Most wells can supply adequate quantities of water for residential and other low-production-uses. Wells in favorable locations typically yield more than $100 \mathrm{gal} / \mathrm{min}$.

\section{Shadygrove and Gatesburg Formations}

The Shadygrove Formation in Big Cove Creek Valley is the lateral equivalent of the Mines Member of the Gatesburg Formation (Berg and others, 1983). Pierce (1966, p.6), in the McConnelsburg quadrangle, mapped these rocks as the upper part of the Conococheague Group. Root (1968) mapped $650 \mathrm{ft}$ of rocks as the Shadygrove Formation in southeastern Franklin County. Clark (1970) recognized a thinner sequence as Shadygrove in western Franklin County but did not give it formation status.

The Gatesburg is the uppermost formation of Cambrian age and consists of five members. In descending order, these are the Mines, upper sandstone, Ore Hill, lower sandstone, and Stacy Members. Only the Mines Member is mapped separately in parts of the Nittany Valley. Here, the remaining four members are grouped as one unit and informally called the "lower members." Each of the lower members was defined by Butts (1918, p. 527). 


\section{Shadygrove Formation}

\section{Description}

The Shadygrove Formation consists of medium-gray, fine-grained, banded limestone containing minor amounts of edgewise conglomerate, oolites, and crossbedded sandstone. Pink and light-gray marbleloid limestones are prominent near the top of the formation. Sandy, light-colored chert blocks are present in the soil residue.

\section{Water-bearing properties}

Yields reported for two wells in the Shadygrove are 30 and $50 \mathrm{gal} / \mathrm{min}$. The only specific capacity is $2[(\mathrm{gal} / \mathrm{min}) / \mathrm{ft}]$. Slightly lower values of specific capacity (median $1.3[(\mathrm{gal} / \mathrm{min}) / \mathrm{ft}]$ ) and well yield (median 18 gal/min) were obtained by Becher and Taylor (1982) in Franklin County.

\section{Water quality}

Data are available from only one well. Water from this well is very hard (190 mg/L as $\mathrm{CaCO}_{3}$ ).

\section{Summary evaluation}

Yields of $50 \mathrm{gal} / \mathrm{min}$ of potable water can be expected from wells in the Shadygrove Formation.

$$
\text { Gatesburg Formation, Undivided }
$$

\section{Description}

The description of the rocks is a composite of those for the individual members, discussed later.

\section{Water-bearing_properties}

Specific capacities for six high-production-use wells in the Gatesburg Formation have median and maximum values of 8.6 and 30 [(gal/min)/ft], respectively. The median and maximum yields reported for eight highproduction-use wells are 165 and $300 \mathrm{gal} / \mathrm{min}$, respectively. For lowproduction-use wells, the median reported yield of 54 wells is $10 \mathrm{gal} / \mathrm{min}$ and the median specific capacity for 19 wells is 0.10 [( $\mathrm{gal} / \mathrm{min}) / \mathrm{ft}]$. About 20 percent of all wells have reported yields that are less than $5 \mathrm{gal} / \mathrm{min}$. 


\section{Water quality}

The median values of $\mathrm{pH}$, specific conductance, and hardness are 7.5, 355 $\mu \mathrm{S} / \mathrm{cm}$, and $154 \mathrm{mg} / \mathrm{L}$ as $\mathrm{CaCO}_{3}$, respectively. The water ranges from soft (17 $\mathrm{mg} / \mathrm{L}$ as $\mathrm{CaCO}_{3}$ ) to very hard $\left(290 \mathrm{mg} / \mathrm{L}\right.$ as $\left.\mathrm{CaCO}_{3}\right)$. Water from one of the 18 wells sampled exceeded the USEPA's SMCL for iron.

\section{Summary evaluation}

Wells commonly yield $100 \mathrm{gal} / \mathrm{min}$, but yields in excess of $500 \mathrm{gal} / \mathrm{min}$ can be obtained. Although the water is hard, water quality is excellent.

\section{Mines Member of Gatesburg Formation}

\section{Description}

The Mines Member is mostly a dark-gray, coarse-grained dolomite. Landon (1963) measured the thickness as $230 \mathrm{ft}$ in the Bellefonte quadrangle but reported $150 \mathrm{ft}$ further south. Weathering of this member leaves a clay soil containing abundant oolitic chert composed of little black spherules in a lighter colored groundmass.

\section{Water-bearing properties}

The clay soil overlying the Mines Member causes water to pond at the surface; at depth, it produces a discontinuous shallow perched water-table system that may be more than $100 \mathrm{ft}$ above the main ground-water system in the Nittany Valley. The specific capacities of two low-production-use wells in the Mines Member are 2.3 and 9.4 , and for the one high-production-use well, 380 [(gal/min)/ft]. The median yield reported for six low-production-use wells is $60 \mathrm{gal} / \mathrm{min}$ and the maximum yield reported is $8,000 \mathrm{gal} / \mathrm{min}$. One half of the 14 yields reported are for wells drilled for high-production-use. No well yield of less than $30 \mathrm{gal} / \mathrm{min}$ is reported from this member.

\section{Water quality}

Water ranges in hardness from soft to very hard (34 to $310 \mathrm{mg} / \mathrm{L}$ as $\left.\mathrm{CaCO}_{3}\right)$. The median $\mathrm{pH}$, hardness, and specific conductance are $7.6,137 \mathrm{mg} / \mathrm{L}$ as $\mathrm{CaCO}_{3}$, and $360 \mu \mathrm{S} / \mathrm{cm}$, respectively. Concentrations in water from one of the three wells sampled exceed the USEPA's SMCL for iron and the MCL for nitrate.

\section{Summary evaluation}

Wells in the Mines Member can supply potable water for high-production needs in excess of $1,000 \mathrm{gal} / \mathrm{min}$. 


\section{Description}

The upper and lower sandstone members have essentially the same lithology. They are composed of dark-gray, thin-bedded, microcrystalline, silty dolomite, that weathers buff-colored; thin-bedded, finely crystalline, shaly dolomite; and coarse-grained quartzose sandstone beds that grade, in ascending order, from conglomerate to sandstone. A 40 -ft zone of interbedded limestone and sandstone is present in the upper sandstone. Each of the sandstone members is about $600 \mathrm{ft}$ thick. Between the sandstone members is the Ore Hill Member, a dark-gray, massively bedded, coarsely crystalline dolomite that is between 130 and $310 \mathrm{ft}$ thick. South of Williamsburg this member grades to thin bedded limestone (Landon, 1963). The Stacy Member is a darkgray medium and coarsely crystalline dolomite interbedded with oolitic and cryptozoan-bearing dolomite. This member is present only in the Snake Spring (Knowles, 1966), Morrison Cove, and Canoe Valleys (Butts, 1945) and is defined as the rocks between the sandstone float of the lower sandstone member and the limestone of the underlying Warrior Formation. Partly as a result of this definition, the Stacy Member is variable in both occurrence and thickness. It is not reported in the Nittany Valley (Wood, 1980) but $68 \mathrm{ft}$ were measured in Snake Spring Valley (Knowles, 1966), and about $500 \mathrm{ft}$ is reported by Butts (1945) in Morrison Cove and Canoe Valley.

\section{Water-bearing properties}

A residual clay soil has formed over the Ore Hill Member and commonly results in ponding of water and a perched water-table, similar to that in the Mines Member. Water levels in wells Ce 408 and $409,800 \mathrm{ft}$ apart, show this condition; these wells are $325 \mathrm{ft}$ and $65 \mathrm{ft}$ deep, respectively. The altitude of water levels in the respective wells is 1,070 and $1,300 \mathrm{ft}$. Sandier soils overlying the other members of the Gatesburg Formation allow the rapid passage of infiltrating water.

The median and maximum specific capacities of 17 high-production-use wells are 21 and 380 [(gal/min)/ft], respectively. For the same use category, the median and maximum reported yields of 18 wells are 467 and $8,000 \mathrm{gal} / \mathrm{min}$, respectively. The medians of 7 specific capacities and 14 reported yields of low-production-use wells are $15[(\mathrm{gal} / \mathrm{min}) / \mathrm{ft}]$ and $60 \mathrm{gal} / \mathrm{min}$. All wells yield more than $5 \mathrm{gal} / \mathrm{min}$.

\section{Water quality}

Water is moderately hard to hard (median hardness $120 \mathrm{mg} / \mathrm{L}$ as $\mathrm{CaCO}_{3}$ ), has a median $\mathrm{pH}$ of 7.6 , and a median specific conductance of $344 \mu \mathrm{S} / \mathrm{cm}$. One of the four water samples analyzed contained iron in excess of USEPA's SMCL. 


\section{Summary evaluation}

Wells in the lower members of the Gatesburg Formation can be expected to provide large supplies of moderately hard water for high-production uses. Yields of more than $1,000 \mathrm{gal} / \mathrm{min}$ can be obtained.

Warrior Formation

\section{Description}

Butts (1918, p. 528) described the Warrior Formation in the Snake Spring Valley. It is also exposed in the Morrison Cove and Canoe Valley (Butts, 1945) and the Nittany Valley (Wilson, 1952). The upper part of the Warrior Formation is dark-gray, mostly limestone with interbedded dolomite, and the lower part is mostly dolomite with some interbedded limestone. Stromatolitic and oolitic beds and interbeds of sandstone or shale are also present. The thickness of this formation is $1,250 \mathrm{ft}$, as measured by Butts (1945) at Williamsburg in the Canoe Valley, and 1,350 ft, as measured by Wilson (1952) at Warriors Mark Creek in the Nittany Valley.

\section{Water-bearing properties}

The median and maximum specific capacities of 13 low-production wells are 0.85 and $2[(\mathrm{gal} / \mathrm{min}) / \mathrm{ft}]$, respectively. The median and maximum of 19 well yields reported are 17 and 150 gal/min, respectively. About 10 percent of all wells have reported yields of less than $5 \mathrm{gal} / \mathrm{min}$.

\section{Water quality}

The median values of $\mathrm{pH}$, specific conductance, and hardness, in the same order, are $7.3,503 \mu \mathrm{S} / \mathrm{cm}$, and $171 \mathrm{mg} / \mathrm{L}$ as $\mathrm{CaCO}_{3}$, respectively. Water ranges from moderately hard ( $100 \mathrm{mg} / \mathrm{L}$ as $\mathrm{CaCO}_{3}$ ) to very hard $\left(380 \mathrm{mg} / \mathrm{L}\right.$ as $\mathrm{CaCO}_{3}$ ).

\section{Summary evaluation}

Almost all wells in the Warrior Formation will yield adequate supplies of good quality water for low-production uses. Well yields of $50 \mathrm{gal} / \mathrm{min}$ or more are common. 
Pleasant Hill and Waynesboro Formations

\section{Description}

The Pleasant Hill Formation is exposed only in small areas of three fault blocks: one in the Nittany Valley, another in the Canoe Valley, and the third in Morrison Cove. The upper $200 \mathrm{ft}$ of this formation is a dark-gray, finegrained limestone containing fossiliferous, oolitic, and conglomerate layers (Butts, 1945). The lower $400 \mathrm{ft}$ is micaceous and weathered outcrops yield shale debris.

The Waynesboro contains greenish-gray and grayish-purple shale, sandstone, quartzite, and conglomerate. Because only part of it is exposed in one small area in Morrison Cove, its total thickness is not known, but it exceeds $200 \mathrm{ft}$.

\section{Summary evaluation}

No well or spring data are available for these formations.

\section{Occurrence and Movement of Water}

Water enters each of the valleys as streamflow, runoff from adjacent ridges, and precipitation. It leaves as water vapor through evaporation and plant transpiration, streamflow, and infiltration into the soil followed by percolation into the ground-water reservoir; most ground water ultimately discharges to streams.

\section{Surface Drainage}

Many small streams drain the valleys. Cove Creek, in the Snake Spring Valley, discharges into the Raystown Branch Juniata River, and Clover Creek, in the Morrison Cove and Canoe Valley, enters the Frankstown Branch of the Juniata River. The Sugar, Brush, and Penns Valleys are drained by Fishing, Elk, and Penns Creeks, respectively. Fishing Creek drains to the north into the West Branch Susquehanna River. Penns Creek receives the drainage from the westward flowing E1k Creek and flows east, eventually discharging into the Susquehanna River. The Nittany Valley is drained by Spruce Creek in the south, Spring Creek in the center, and Little Fishing Creek in the north. Spruce Creek flows southward into the Raystown Branch Juniata River; Spring Creek and Little Fishing Creek flow northwestward into Bald Eagle Creek, and their combined flow eventually reaches the West Branch Susquehanna River. Kishacoquillas Creek drains the Kishacoquillas Valley and flows southward to the Juniata River. Blacklog Creek drains Locke-Blacklog Valley to the west and its waters eventually flow northward into the Juniata River. Big Cove Creek, in the valley of the same name, also drains to the west, but its water flows southward and discharges through the Potomac River basin. 
Ground-water recharge

The carbonate aquifer is recharged from precipitation directly by infiltration and indirectly by infiltration of the surface runoff from adjacent mountains. Direct recharge occurs almost everywhere in the carbonate valleys. Recharge is greatest during the period from about October through April each year when temperatures are lowest and vegetation is dormant. However, recharge of the carbonate aquifer occurs at any time of year from a steady soaking rain.

The recharge process is complex inasmuch as percolation rates vary and arrival in the main ground-water body may lag precipitation by hours, days, months, or perhaps even years. Soil thickness, texture, composition, inhomogeneity, and moisture content control percolation to the main groundwater reservoir. Clay in soils formed over the argillaceous limestone of the Coburn through Loysburg Formations locally retards downward movement. Water that enters the soil can move laterally and downgradient for long distances before entering the main ground-water reservoir. Meiser and Ear1 (1977) describe a three-part ground-water system in the soil overburden and rock of these limestone formations northeast of State College near Nittany Mountain. They report a "near-surface soil system, an intermediate-level saturated bedrock water table, and a deep conduit underdrain system. These systems must be imperfectly interconnected* * *the surface system must leak through the soil to some extent to provide recharge to the bedrock water table; and the saturated bedding planes and fractures of the intermediate system leak slowly, because of the poor degree of their interconnection, to the conduit* **." Some recharge must enter all three systems as water levels rise quickly in each following precipitation.

Direct recharge to the main body of ground water in the Gatesburg Formation may be delayed for months. The hydrograph of well Ce 118 (fig. 4) in the Gatesburg Formation of the Nittany Valley shows only a seasonal rise and fall with a lag time of several months. Individual storms do not cause rises in water level, and dry periods do not cause declines in water level as can be seen in the hydrograph for well Ce 636 (fig. 5) in Penns Valley. Instead, some water is perched above the Gatesburg Formation in local groundwater systems near land surface and in nearby ponds. Residual clay, probably from the Mines and Ore Hill Members (Landon, 1963, p. 62), thick overburden (commonly 100 to $200 \mathrm{ft}$ ) and the deep water levels (commonly exceeding $200 \mathrm{ft}$ ) are the main causes for the delayed recharge. A lag of 1 year in recharge to the Gatesburg Formation is reported by Giddings (1974, p. 30) for 1967 , following a 7 -year period of drought. 

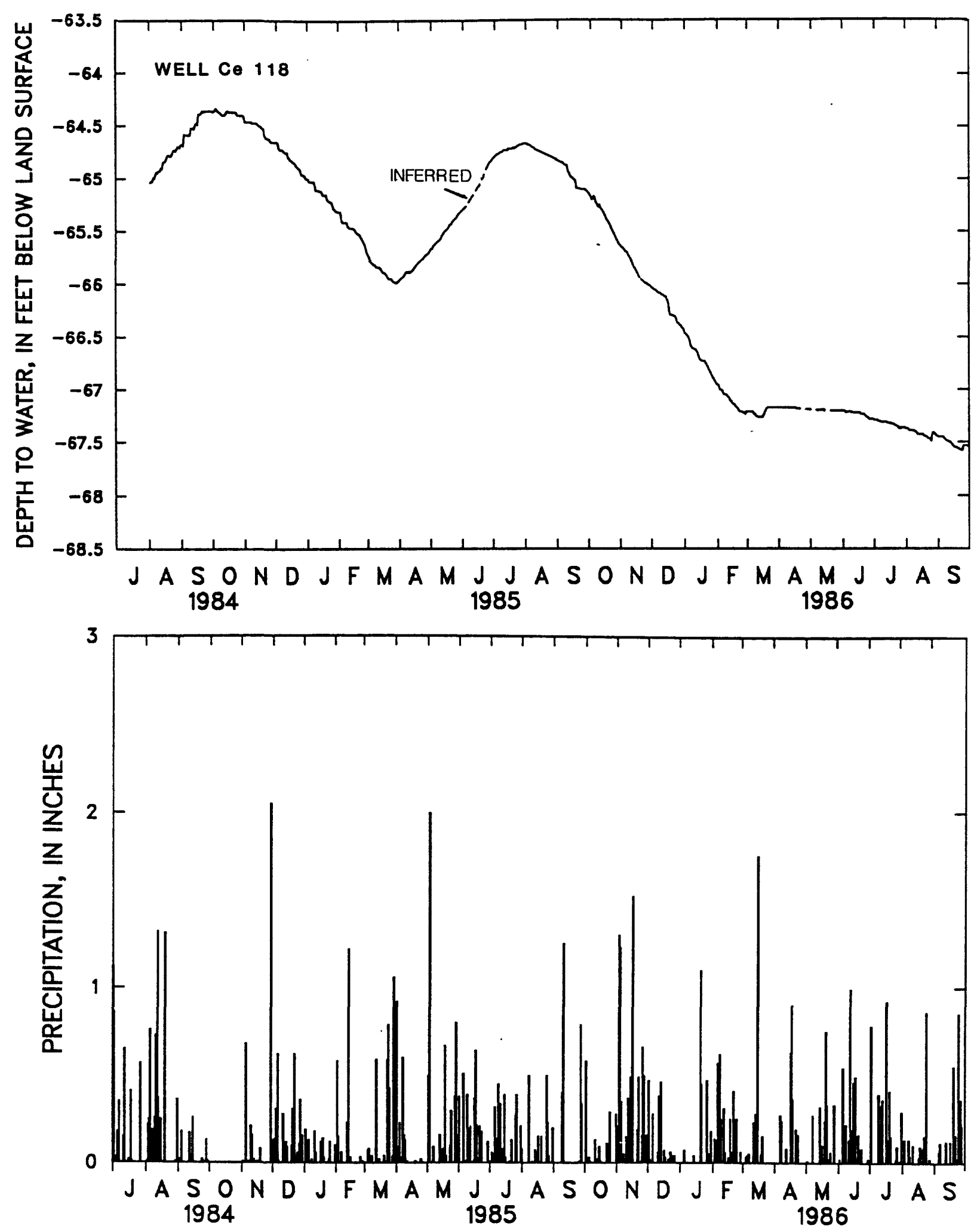

Figure 4.-Hydrograph of well Ce 118 in the Gatesburg Formation and daily precipitation at State College, Pennsylvania. 

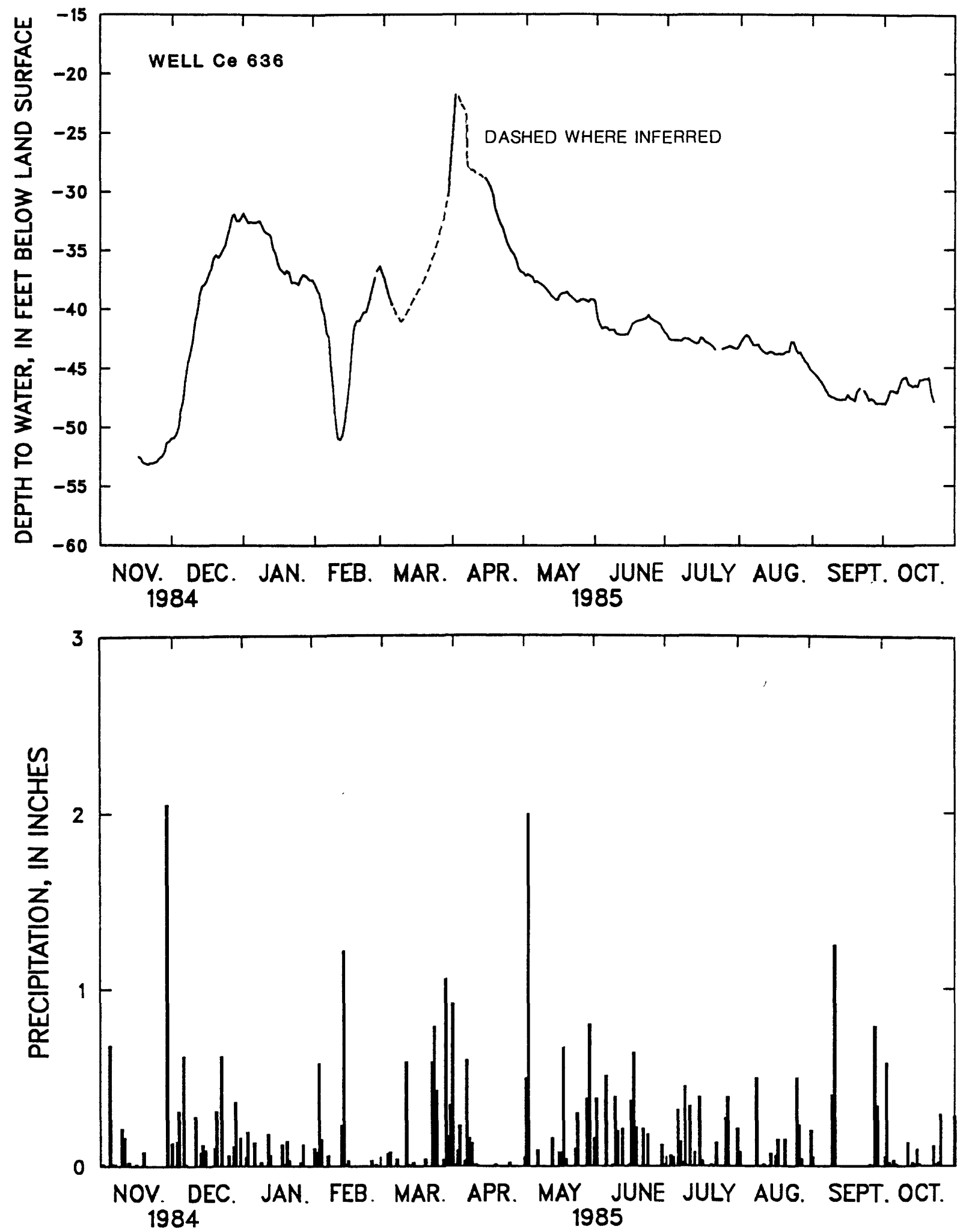

Figure 5.-Hydrograph of well $\mathrm{Ce} 636$ in the undivided Coburn through Nealmont Formations and daily precipitation at State College, Pennsylvania. 
Water infiltrating the colluvium on the flanks of mountain ridges, either directly from precipitation or through stream channels, is an important source of recharge to the carbonate-rock aquifers in the adjacent valleys. Konikow (1969, p. 111) calculated that 80 percent of this water enters the carbonaterock aquifers in the Nittany valley, but only 25 percent actually increased ground-water storage. Most water from mountain streams that enters the carbonate aquifer returns to the surface, usually only a short distance down the valley, through springs fed by conduits in the limestone formations immediately adjacent to the mountain flanks. Discharge from these springs may be large, exceeding $10,000 \mathrm{gal} / \mathrm{min}$, in response to precipitation and snowmelt, but baseflows commonly are an order of magnitude lower and can be zero.

Water levels

Water levels rise as net storage increases in response to recharge and fall as net storage decreases in response to discharge from the aquifer, either by natural processes or by pumping. The hydrographs of wells reflect changes in aquifer storage. Seasonal changes are shown most clearly by figures 6 and 7, the hydrographs of wells Bd 508 and Ce 580 in Snake Spring and Nittany valleys, respectively. The boreholes of these wells do not intercept percolating water directly. Therefore, only the widely distributed effects of recharge from individual rainfalls appear in the hydrograph.

Contours of the potentiometric surface, based on water-level measurements made in a network of about 500 wells, are shown on plates 1 and $2^{2}$. Water-level measurements were made in May 1984, for wells in the Kishacoquillas and Snake Spring Valleys; in April through June of 1984, for wells in Morrison Cove and Canoe Valley; in April and May of 1985, for wells in the Sugar, Brush, Penns, and Nittany Valleys; in June and July of 1985, for wells in Big Cove Creek Valley; and in July 1986, for wells in Locke-Blacklog valley.

The potentiometric contours show that ground water tends to flow from the mountains toward the valley centers and then laterally down the valley. Although movement tends to be toward the valley centers, much of the conduit flow is parallel to the valley trend, even along the valley sides.

Water-level measurements also were obtained for the network wells in the fall of the same year the spring measurements were made in all but Big Cove Creek and Locke-Blacklog Valleys.

Statistical comparison of the changes in water level from spring to fall, by geologic unit, shows that the water levels decline least in the Gatesburg Formation; the average decline is $2.2 \mathrm{ft}$, excluding the maximum and minimum 10 percent of the changes. The upper and lower 10 percent of the data was excluded to eliminate major affects from a few large or small changes in water level on the data. Seasonal declines in the Gatesburg are greatest in the Nittany Valley (averaging $2.9 \mathrm{ft}$ ) where withdrawals also are greatest. Maximum declines in water level were in the Bellefonte Formation of Penns and Sugar valleys. The decline averaged $21 \mathrm{ft}$, excluding the maximum and minimum 10 percent of the changes. Average seasonal declines for all valleys and rock units was $9 \mathrm{ft}$.

\footnotetext{
2 Plates are on file in the U.S. Geological Survey, Pennsylvania District Library.
} 

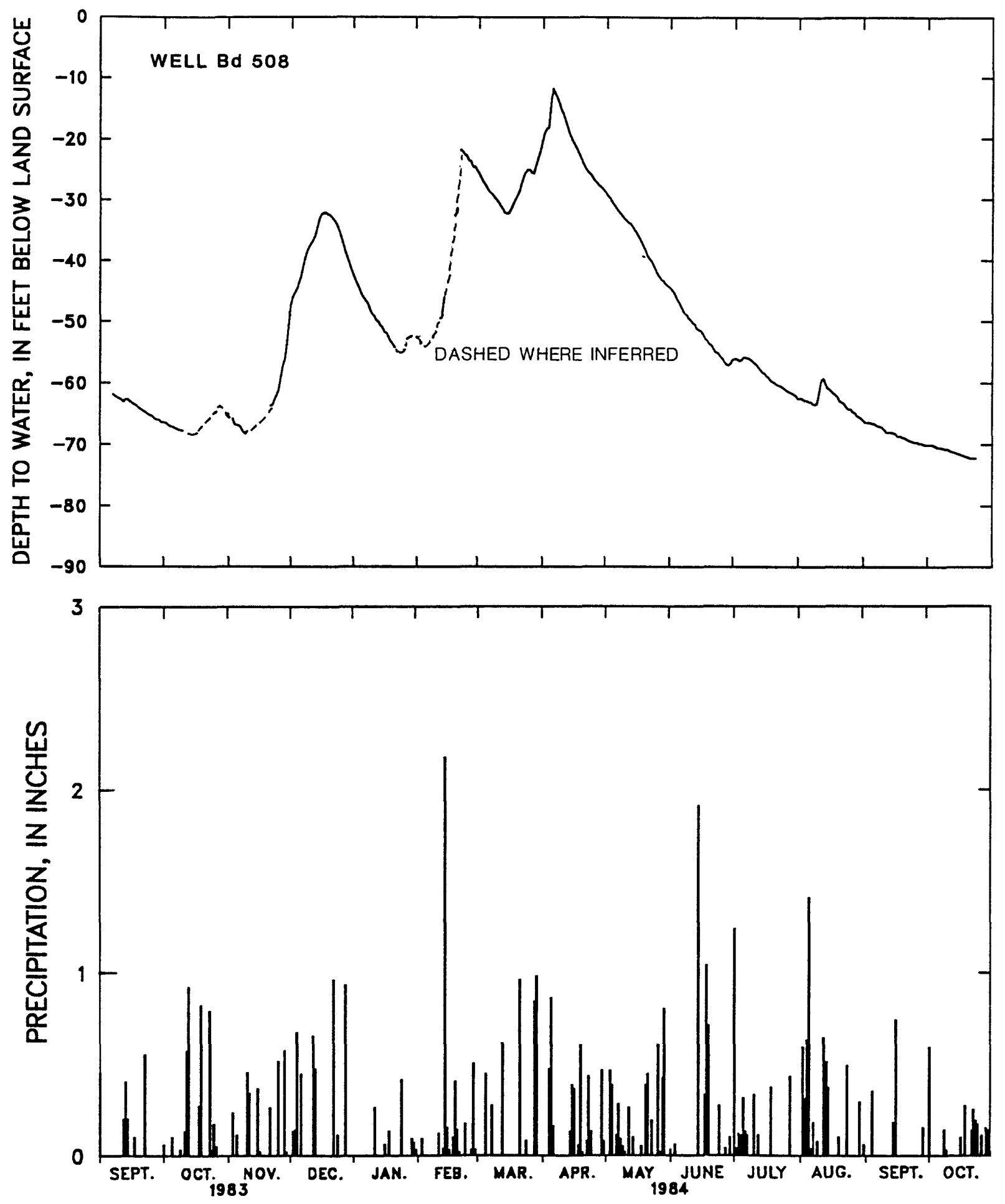

Figure 6.--Hydrograph of well Bd 508 in the undivided Nittany and Larke Formations and daily precipitation at Martinsburg. Pennsylvania. 

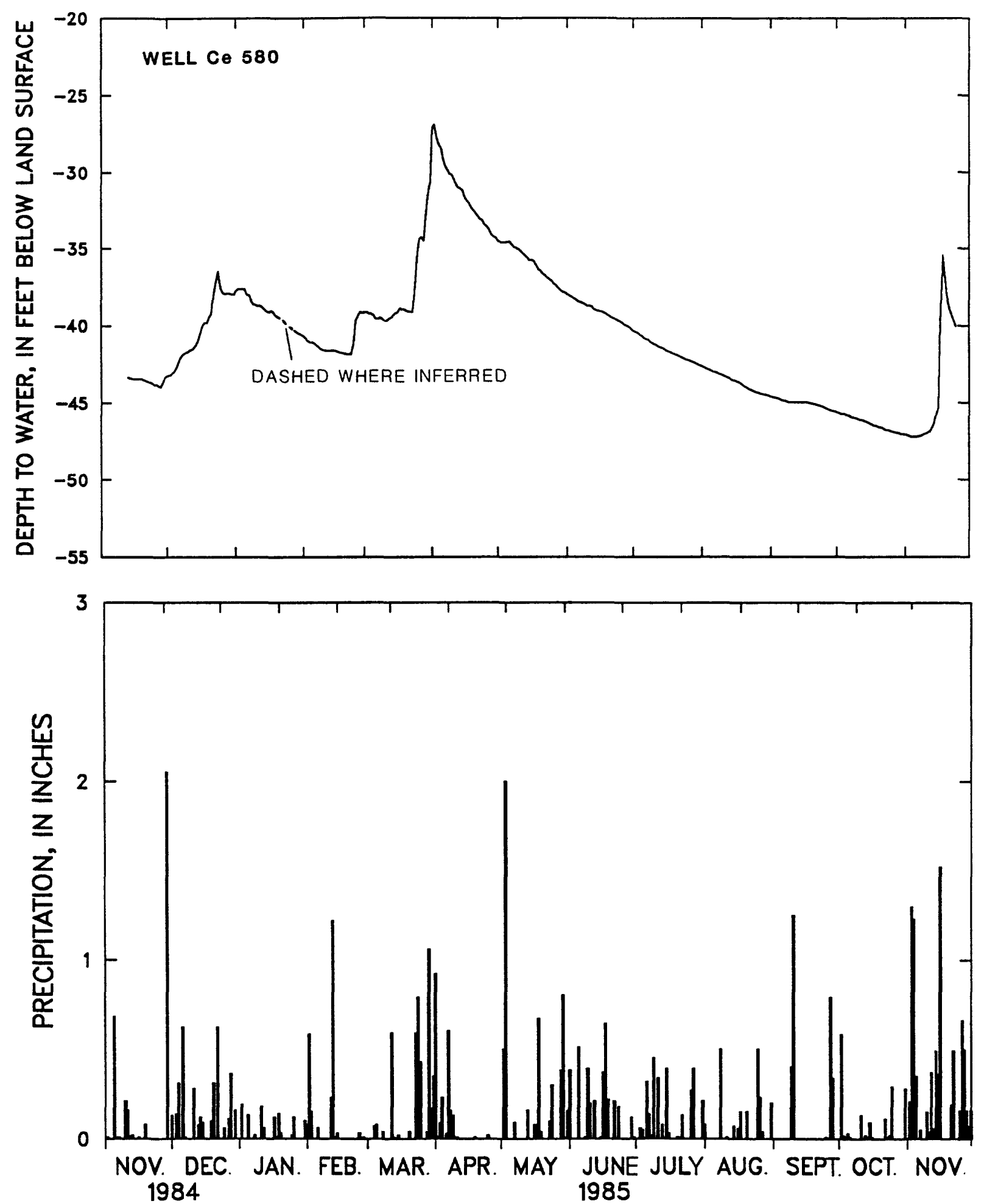

Figure 7.--Hydrograph of well Ce 580 in the Gatesburg Formation and daily percipitation at State College, Pennsylvania. 


\section{Relation between ground water and surface water}

Within the valleys, ground water discharges through many large and small springs. Commonly, water re-enters the ground-water reservoir through permeable sediments in stream beds or swallow holes (fig. 8). Studies by Landon (1963), Konikow (1969), and Krothe (1976) discuss the gaining and losing character of streams in the Nittany Valley. Moorshead (1975) documented infiltration rates on several streams in the Nittany Valley. His estimates range from 10 to 150 [(gal/day)/ft ${ }^{2}$ ] (gallons per day per square foot). He reported a median infiltration rate of 25 [(gal/day)/ft ${ }^{2}$ ].

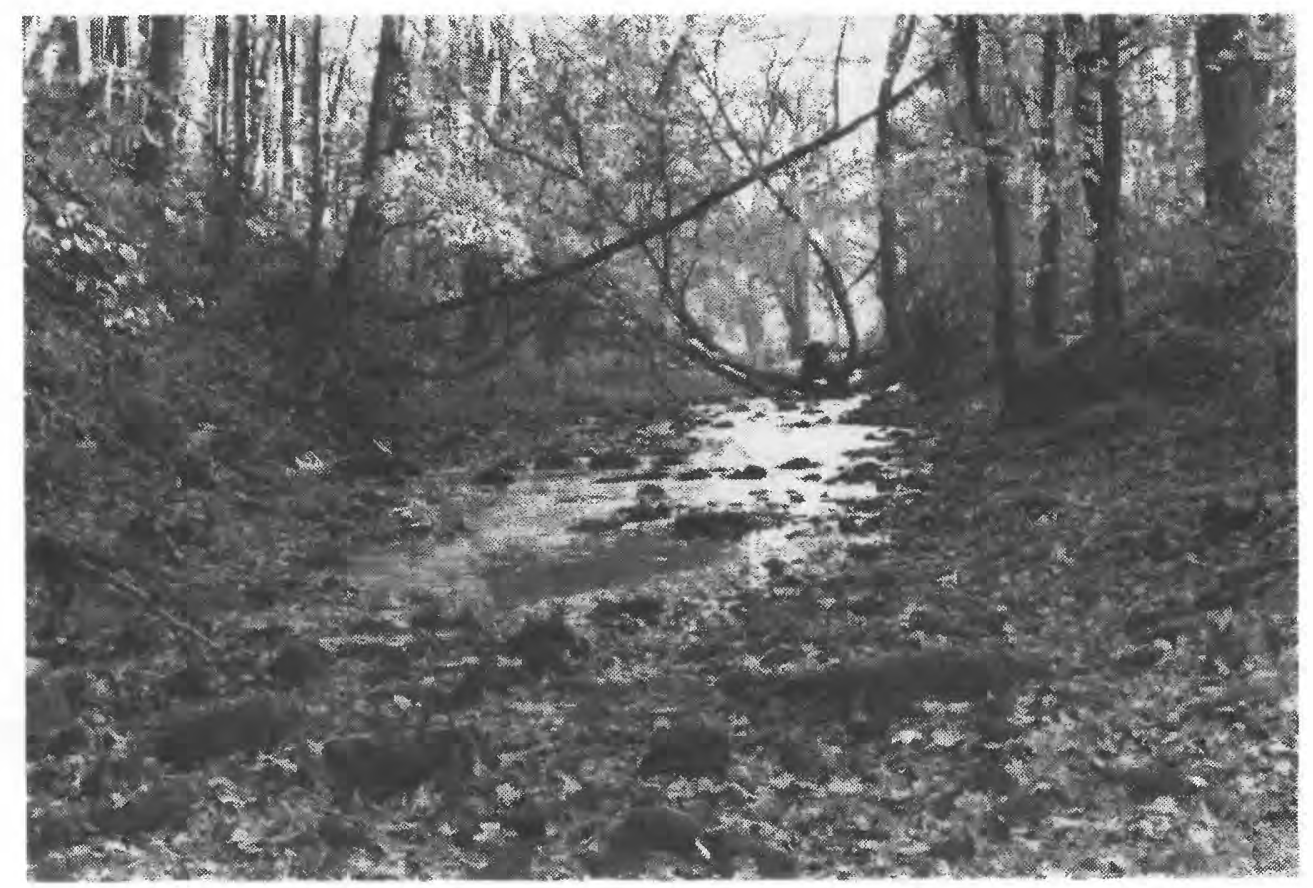

Figure 8.--Upstream view of Sinking Run about 1,500 feet downstream from Arch Spring in the Nittany Valley showing where water sinks into stream bed.

\section{Springs}

Al1 recharge is discharged eventually from the aquifers through springs that range in flow from a few gallons per day to measured volumes in excess of $14,000 \mathrm{gal} / \mathrm{min}$ ( $t a b l e ~ 2)$. The average annual discharge of all springs in a ground-water basin is a good estimate of recharge and therefore a measure of the supply of water available for consumptive use. 


\section{Water Budget}

A water budget is a quantitative expression of the balance between the major components of water moving in and out of an area. It is a measure of the total water resource available under natural conditions. A simplified equation of this balance that assumes no inflow enters the system from across ground-water divides is:

$$
P=R s+R g+\Delta S+E T
$$

where $\quad P=$ precipitation,

Rs = the surface-runoff component of total streamflow,

$\mathrm{Rg}=$ the ground-water-discharge component of total streamflow (base flow),

$\Delta \mathrm{S}=$ change in ground-water storage, and

$\mathrm{ET}=$ water loss (chiefly evaporation and transpiration).

Water budgets were developed for two of the ground-water basins in the study area. Each selected basin has a long streamflow record and is representative of one of the two hydrogeologic basin types prevalent in the carbonate valleys. The Spring Creek ground-water basin contains a central area underlain by interbeds of carbonate-cemented sandstone and sandy dolomite of Cambrian age, including the Gatesburg Formation, that is characteristic of all the western-most carbonate valleys. The Kishacoquillas Creek ground-water basin and the remaining carbonate valleys, with the exception of Big Cove Creek Valley, expose only Ordovician age carbonates, largely interbedded limestone and shaly limestone. The sandy Cambrian age rocks that lie deep beneath younger carbonates have not been tested but probably store little, if any, usable fresh water.

Table 4 shows the average annual water budgets for the Kishacoquillas Creek for water years 1941-70 and for Spring Creek for 1968-83. Data for long, equivalent periods of time were not available for these stations. Water budgets are also shown for the 1984 and 1985 water years in both basins.

Table 4.--Water budgets for representative ground-water basins

[All values are in inches unless stated otherwise;

-- , no data]

\begin{tabular}{|c|c|c|c|c|}
\hline Water year(s) & $\begin{array}{l}\text { Precipitation } 1 \\
\text { (P) }\end{array}$ & $\begin{array}{l}\text { Surface } \\
\text { runoff } \\
\text { (Rs) }\end{array}$ & $\begin{array}{l}\text { Ground- } \\
\text { water } \\
\text { discharge } \\
(\mathrm{Rg})\end{array}$ & $\begin{array}{c}\text { Water } \\
\text { losses } \\
\text { (ET) }\end{array}$ \\
\hline $\begin{array}{l}\text { 1968-83 (average) } \\
\text { Percent of precipitation } \\
1984 \\
\text { Percent of precipitation } \\
1985 \\
\text { Percent of precipitation }\end{array}$ & $\begin{array}{c}\text { ng Creek at Mile } \\
39.30 \\
-- \\
46.07 \\
-- \\
35.38 \\
--\end{array}$ & $\begin{array}{l}\frac{\text { burg }}{2.23} \\
6 \\
3.62 \\
8 . \\
1.10 \\
3\end{array}$ & $\begin{array}{l}16.54 \\
42.20 \\
20.20 \\
44 \\
16.35 \\
46\end{array}$ & $\begin{array}{l}20.53 \\
52 \\
22.25 \\
48 \\
17.93 \\
51\end{array}$ \\
\hline $\begin{array}{l}\text { 1941-70 (average) Kish } \\
\text { Percent of precipitation } \\
1984 \\
\text { Percent of precipitation } \\
1985 \\
\text { Percent of precipitation }\end{array}$ & $\begin{array}{c}\text { cuillas Creek at } \\
38.17 \\
52.90 \\
40.50 \\
--\end{array}$ & $\begin{array}{l}\text { Reedsville } \\
3.95 \\
10 \\
7.80 \\
15 \\
2.62 \\
7\end{array}$ & $\begin{array}{l}12.98 \\
34 \\
17.28 \\
33 \\
12.18 \\
30\end{array}$ & $\begin{array}{l}21.24 \\
56 \\
27.82 \\
52.70 \\
25.70 \\
63\end{array}$ \\
\hline
\end{tabular}

1 Precipitation for Spring Creek is at State College (precipitation for April and September 1984, and April and May 1985 is at Tyrone). Precipitation for Kishacoquillas Creek is at Milroy (precipitation for water years 1941-43, 1951, and some months in 1945 and 1952 is at Lewistown). 


\section{Precipitation}

Records of the U.S. Weather Bureau stations at Milroy and Lewistown provided precipitation ( $P$ in equation 1 ) data for the Kishacoquillas groundwater basin and from the stations at State College and Tyrone for the Spring Creek ground-water basin. Records from Lewistown and Tyrone were used to provide data during periods of missing data at Milroy and State College.

Precipitation varies monthly, seasonally, and annually, as well as geographically. Figures 9 and 10 illustrate the temporal variability. These two bar graphs compare the geographic variability of precipitation between stations that are less than $20 \mathrm{mi}$ apart. Long term average monthly precipitation shown on the graphs indicates that each of the summer months of May through August average about 25 percent more precipitation than the other months of the year. Summer precipitation is also the most variable geographically, because most of it comes from local showers and thunderstorms rather than the regional storm patterns prevalent at other times of the year.

Precipitation averaged $38.17 \mathrm{in}$. in the Kishacoquillas basin for the 30 year period from 1941-70 and 39.30 in. in the Spring Creek basin for the 16year period from 1968-83. A comparison of these averages with precipitation in 1984 and 1985 indicates that, in 1984, precipitation exceeded the average by 39 percent in the Kishacoquillas Valley and 17 percent in the Spring Creek basin. For 1985, precipitation was 6 percent above average in the Kishacoquillas basin and 11 percent below average in the Spring Creek basin.

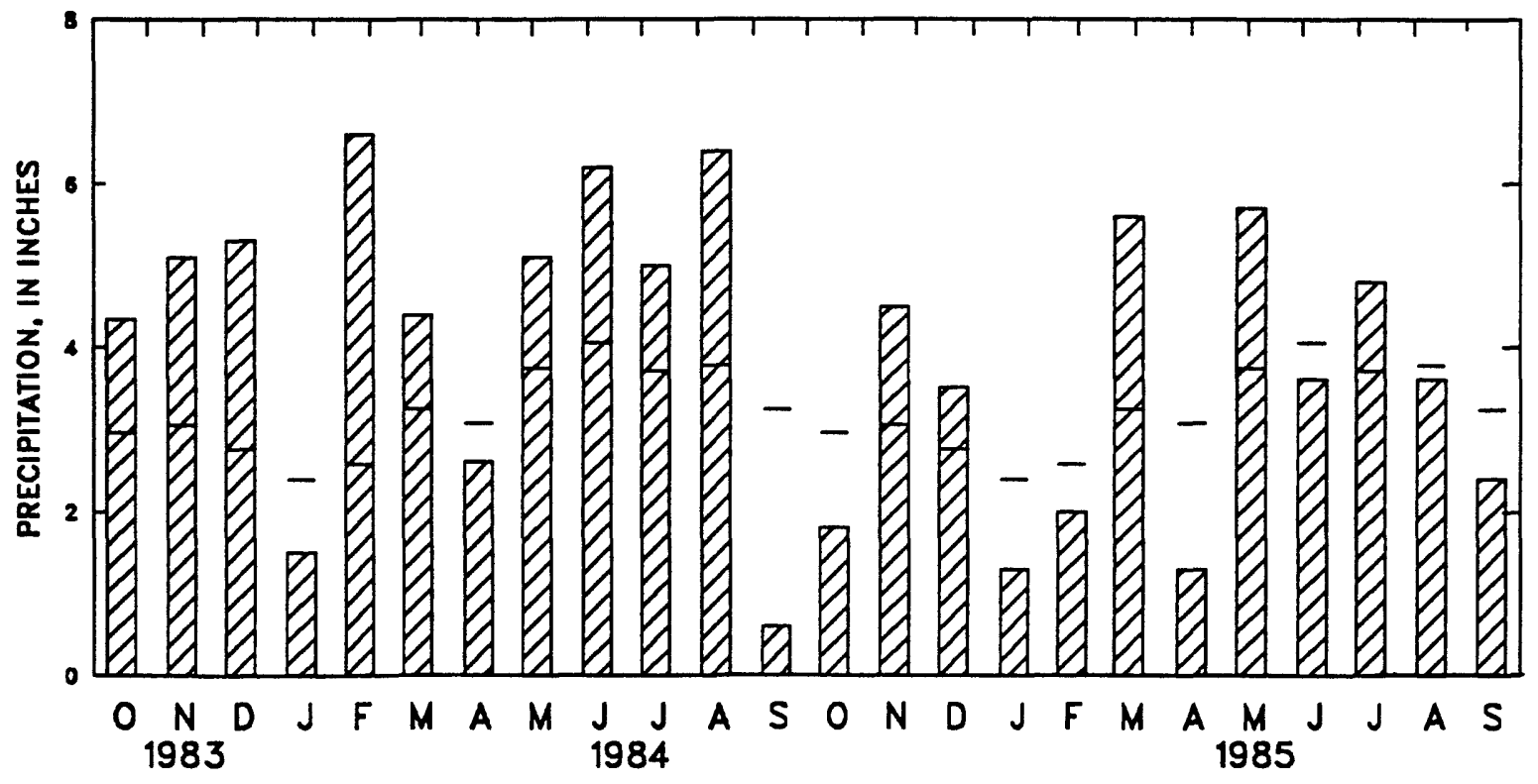

Figure 9.--Monthly precipitation during water years 1984-85 at Milroy, Pennsylvania and average monthly precipitation from 1941-70. 


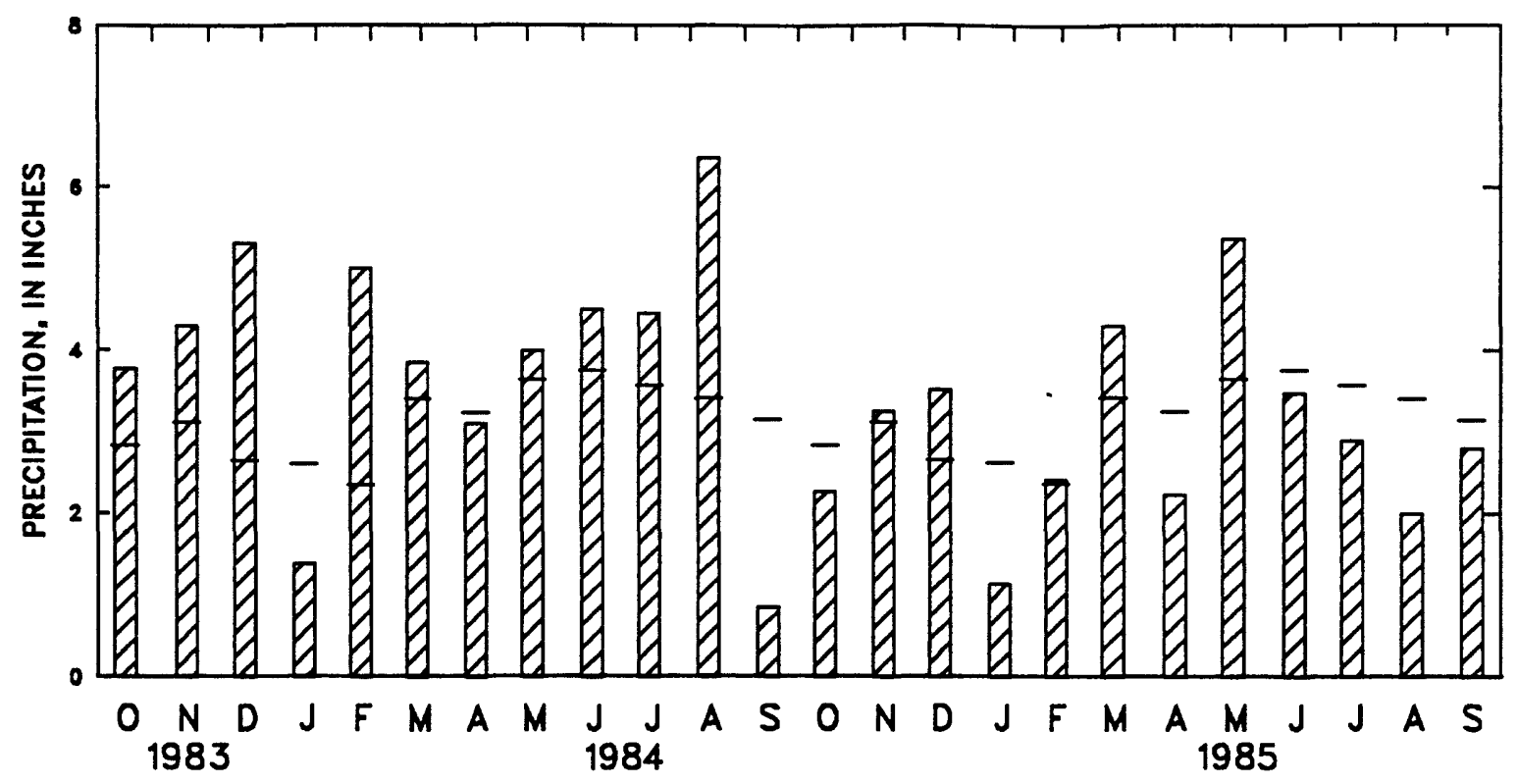

Figure 10.--Monthly precipitation during water years 1984-85 at State College, Pennsylvania and average monthly precipitation from 1968-83.

\section{Streamflow}

Streamflow ( $\mathrm{Rg}+\mathrm{Rs}$ in equation 1 ) was obtained from records of the U.S. Geological Survey for gaging stations on Kishacoquillas Creek at Reedsville (1941-70, 1984, 1985) and Spring Creek at Milesburg (1968-85). Between 1970 and 1984, the Reedsville station was not active, and the Milesburg station was not established until 1968. The average annual streamflow for Kishacoquillas Creek and Spring Creek are $6.454 \times 10^{9} \mathrm{ft}^{3}$ (cubic feet) and $7.371 \times 10^{9} \mathrm{ft}^{3}$, respectively. These discharges are equivalent to $16.93 \mathrm{in}$. and $18.77 \mathrm{in}$. spread across the respective basins.

\section{Ground-Water Discharge}

The importance of ground-water input (base flow or $\mathrm{Rg}$ in equation 1) to total streamflow is shown by the hydrographs in figures 11 and 12 . In summer and fall, streamflow is maintained almost entirely by ground-water discharge. Only in winter and spring is direct runoff a significant part of streamflow.

Base flow was separated from total flow using the "Fixed Interval Method" developed for computer analysis of daily streamflow by Pettyjohn and Henning (1979). Ground-water discharge and base flow are considered to be equivalent terms since little, if any, water can bypass the gaging stations.

Ground-water discharge averaged $4.946 \times 10^{9} \mathrm{ft}^{3}$ annually from the Kishacoquillas Creek basin and $6.57 \times 10^{9} \mathrm{ft}^{3}$ from the Spring Creek basin. These discharges are equivalent to 12.98 and $16.54 \mathrm{in}$. spread over the respective ground-water basins. Ground-water discharge accounts for about 34 and 42 percent of precipitation in the Kishacoquillas and Spring Creek basins, respectively. 


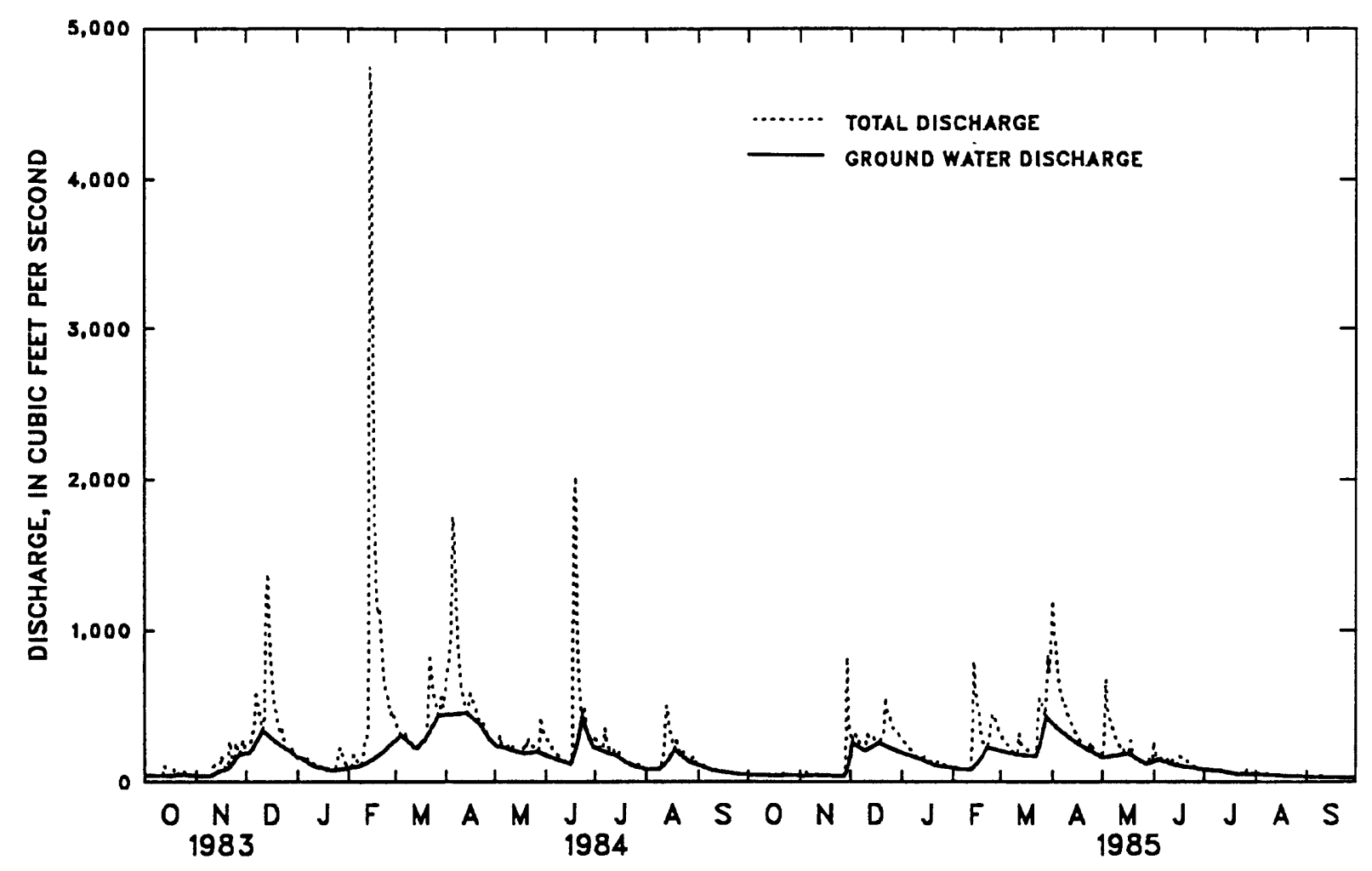

Figure.11.--Discharge of Kishacoquillas Creek at Reedsville, Pennsylvania, water year 1984-85.

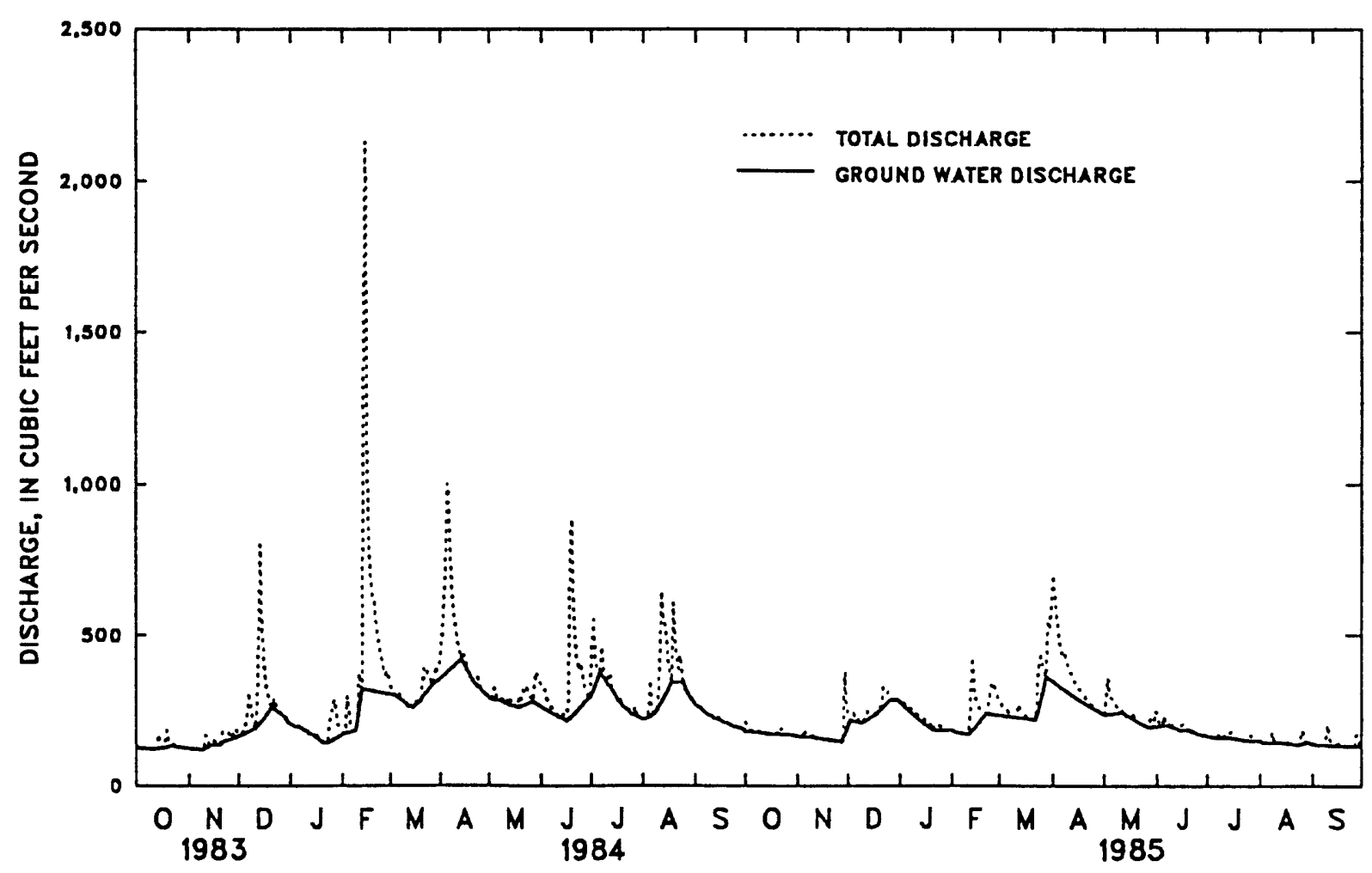

Figure 12.--Discharge of Spring Creek at Milesburg, Pennsylvania, water year 1984-85. 


\section{Surface Runoff}

Surface runoff (Rs in equation 1 ) was computed as the difference between total streamflow and ground-water discharge. Runoff averaged $1.508 \times 10^{9} \mathrm{ft}^{3}$ from the Kishacoquillas Creek basin and $0.881 \times 10^{9} \mathrm{ft}^{3}$ from the Spring Creek basin. These amounts are equivalent to 3.95 and $2.23 \mathrm{in}$. spread over the respective ground-water basins.

\section{Evapotranspiration}

Water lost to the atmosphere by evaporation from surface bodies of water, wetted surfaces, moist soil, and by transpiration of plants constitute the largest output component in the water budget. Evapotranspiration (ET in equation 1) losses decline rapidly in early fall as plant growth stops and temperatures decrease. Through late fall and winter, ET is negligible, but in early spring it increases rapidly and reaches a maximum in summer. Commonly, recharge to the ground-water system and streamflow are greatest when ET is least and least when ET is greatest.

ET was calculated in the budget as the difference between precipitation and total streamflow. The average annual loss to ET is 21.24 in. from the Kishacoquillas basin and 20.53 in. from the Spring Creek basin. These losses constitute 56 percent and 52 percent of average annual precipitation in the respective basins.

\section{Ground-Water Storage}

Normally, changes in ground-water storage ( $\Delta S$ in equation 1 ) are large from season to season but are negligible when averaged over periods of many years. Similarly, the amount of soil moisture stored in the unsaturated zone above the water table may vary by several inches from season to season or from year to year but when averaged over periods of many years is not a significant amount. Therefore, in the long-term budget analysis in table 4, ground-water storage changes are assumed to be zero. In other words, recharge equals discharge over the long term.

A small net change in ground-water and soil-moisture storage are believed to have occurred during the project in the 2-year period between October 1983 and September 1985. Base flow at the beginning of water year 1984 was nearly the same as at the end of water year 1985 in both basins and was the total flow both of these times. Precipitation in late September 1985 was sufficient at both Lewistown and State College stations to cause some additions to soil moisture content. Although the hydrographs of wells Mf 344 and Mf 367 , in the Kishacoquillas Valley (fig. 13), did not show any residual additions to storage from the precipitation, ground-water levels were slightly higher at the end of the 2-year period than at the beginning. Most of the precipitation was lost to ET, based on the effects shown in stream and well hydrographs. Net changes to ground-water storage for the period are believed to be less than 0.2 in. and were not considered significant in the water budget

(table 4). 

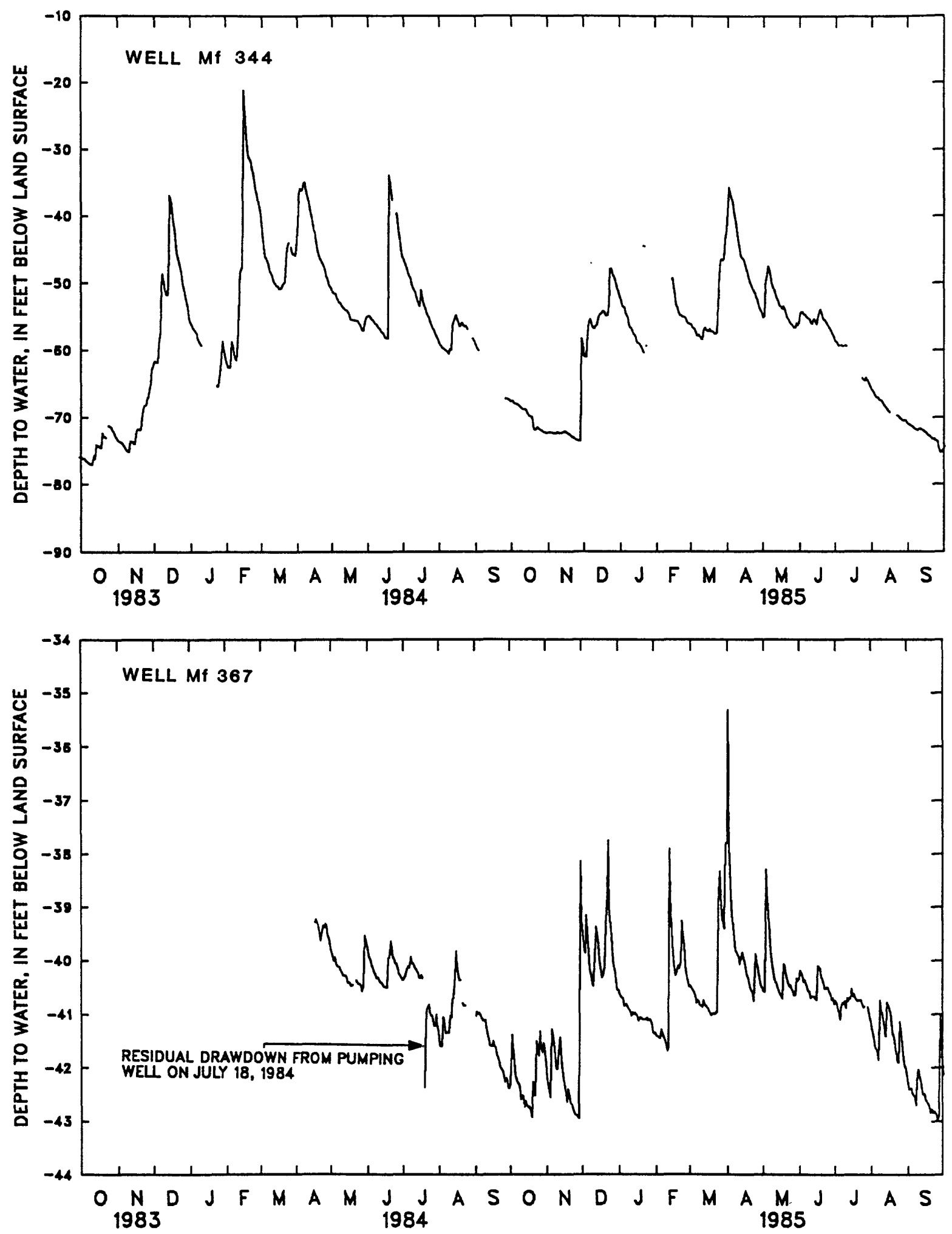

Figure 13--Water levels in wells Mf 344 and Mf 367. 


\section{Availability of Water}

A reasonable estimate of the quantities of ground water available for use in the valleys can be calculated from the water-budget study. Most surface runoff moves out of the drainage basin within 3 days after the rainfall that produced it and is not available for in-basin uses. Ground water is the only continuously reliable source of water.

The average discharge of ground water to streams is $0.62 \mathrm{Mgal} / \mathrm{d}$ for each square mile of land surface in the Kishacoquillas Creek ground-water basin. Comparatively, $0.80 \mathrm{Mgal} / \mathrm{d}$ of ground water discharges for each square mile of land surface in the Spring Creek ground-water basin. These amounts are available for use even if none of the water re-enters the ground-water system after use. However, to have these amounts of water available, the ground water must be captured rather than allowed to leave the basin and severely deplete the streamflow. During drought years only $0.34 \mathrm{Mgal} / \mathrm{d}$ and $0.45 \mathrm{Mgal} / \mathrm{d}$ of water for each square mile in the Kishacoquillas and Spring Creek basins are available, respectively, based on the minimum annual ground-water discharges.

The calculated yields available from the Spring Creek basin can be extended to all the western carbonate valleys (Snake Spring, Morrison Cove, Canoe, and Nittany) because of their similar hydrogeologic characteristics. Extrapolation of the calculated yields available for the Kishacoquillas Creek basin to the remaining carbonate valleys is reasonable, but there is more diversity in hydrogeologic character between these valleys than between the western carbonate valleys.

The yields given are averages only and cannot be applied directly in any small area. Inhomogeneities in the hydrogeologic character of the rocks will reduce the yields below these averages in some areas and increase them in other areas. A comparison of area yields based on formation statistics and multiple-well aquifer tests is discussed in a later section of this report.

\section{WATER YIELDING PROPERTIES OF ROCK UNITS}

Aquifers are rocks or rock materials that store water in openings and transmit usable quantities to wells and springs. Openings in unconsolidated rock aquifers, such as the colluvium on the mountain slopes and the residuum under the valley floors, are the voids between packed grains. Openings in the consolidated carbonate-rock aquifers are separations along breaks in the rocks; some rock formations tend to develop more openings than others and are better aquifers. The breaks in the rocks include bedding partings, faults, and joints caused by physical stress. Any of these types of openings may be enlarged gradually by the chemical reaction of weak acids in water on the carbonate minerals that form these rocks. The size, spacing, distribution, and extent of interconnection of the openings determine the ability of the aquifer to store and transmit water. 


\section{We11 Characteristics}

A well must intercept at least one opening that is water-bearing to yield any water. Data on the distribution of water-bearing zones (WBZs) intercepted by many wells are useful in assessing the yielding properties of formations. Figures 14 through 18 summarize the statistics on WBZs below the bottom of casing, from well-completion reports filed by drillers with the Pennsylvania Bureau of Topographic and Geologic Survey. The distributions of WBZs in the Mines Member of the Gatesburg Formation and the Stonehenge Formation suggest that the sample size is too small for complete evaluation of the occurrence of WBZs. For most formations, the maximum number of WBZs are encountered turn 51 to $150 \mathrm{ft}$ below land surface. For all wells in the Gatesburg Formation, the maximum number of WBZs are encountered at depths below $150 \mathrm{ft}$.

The ratio of the number of WBZs to total footage of hole drilled reduces the bias in the data created by shallow drilling. The open bars in figures 14 through 18 indicate that the number of WBZs encountered relative to the total footage of hole penetrated commonly is a maximum in the two shallowest $50 \mathrm{ft}$ ranges. Further, the chances of encountering a WBZ are more evenly divided throughout the range of depth than is indicated by the raw data. WBZs have been encountered in the Gatesburg Formation only to depths of $450 \mathrm{ft}$, although 10 wells penetrate greater depths and 5 of these have reported WBZ data. However, because all but one of the five for which WBZ data are available yield more than $150 \mathrm{gal} / \mathrm{min}$, additional small amounts of water encountered at greater depths may not have been detected during drilling. Therefore, WBZs may be encountered at depths greater than $450 \mathrm{ft}$ in the Gatesburg Formation. Conversely, the WBZs reported to depths of $600 \mathrm{ft}$ for wells in the Coburn through Nealmont Formations may be only another indication of the low yields available from these rocks. Small additional amounts of water intercepted during drilling are noticeable when the well yields little water. WBZs may be encountered at greater depths than the maximum shown by the bar graphs for other formations, inasmuch as the maximum depth of wells are the same, or only slightly deeper, for these formations than the deepest zone reported.

Further, the number of WBZs for each $100 \mathrm{ft}$ of hole drilled does not decrease markedly with depth for most formations, and actually increases for some formations.

Statistics about the depths of wells, casing, and static water levels are useful in inferring hydrogeologic characteristics of rock units and comparing different rock units. This information is helpful not only in understanding the hydrogeology but also in estimating well-construction costs. Median and quartile statistics of the frequency distributions of this data are shown graphically in figures 19-21.

The thick sandy residuum overlying the Gatesburg Formation forces the drilling of deeper wells in this formation than in other formations. Wells in the lower members and the undivided Gatesburg have a median depth that is 75 to $150 \mathrm{ft}$ greater than that of wells in any other geologic unit. Similarly, the thick residuum and fine loose sand in some WBZs cause wells in the Gatesburg Formation to be cased to greater depths than most other geologic units. 
Median water levels for all formations younger than the Nittany Formation range from about 30 to $60 \mathrm{ft}$ below land surface. Older rocks, of the Nittany Larke, Stonehenge, Gatesburg, and Warrior Formations, crop out chiefly in central parts of western valleys and have median water levels that range from 60 to $120 \mathrm{ft}$. Water levels in the Gatesburg are the deepest of all formations and exceed over $400 \mathrm{ft}$ in the widest part of the Nittany Valley.
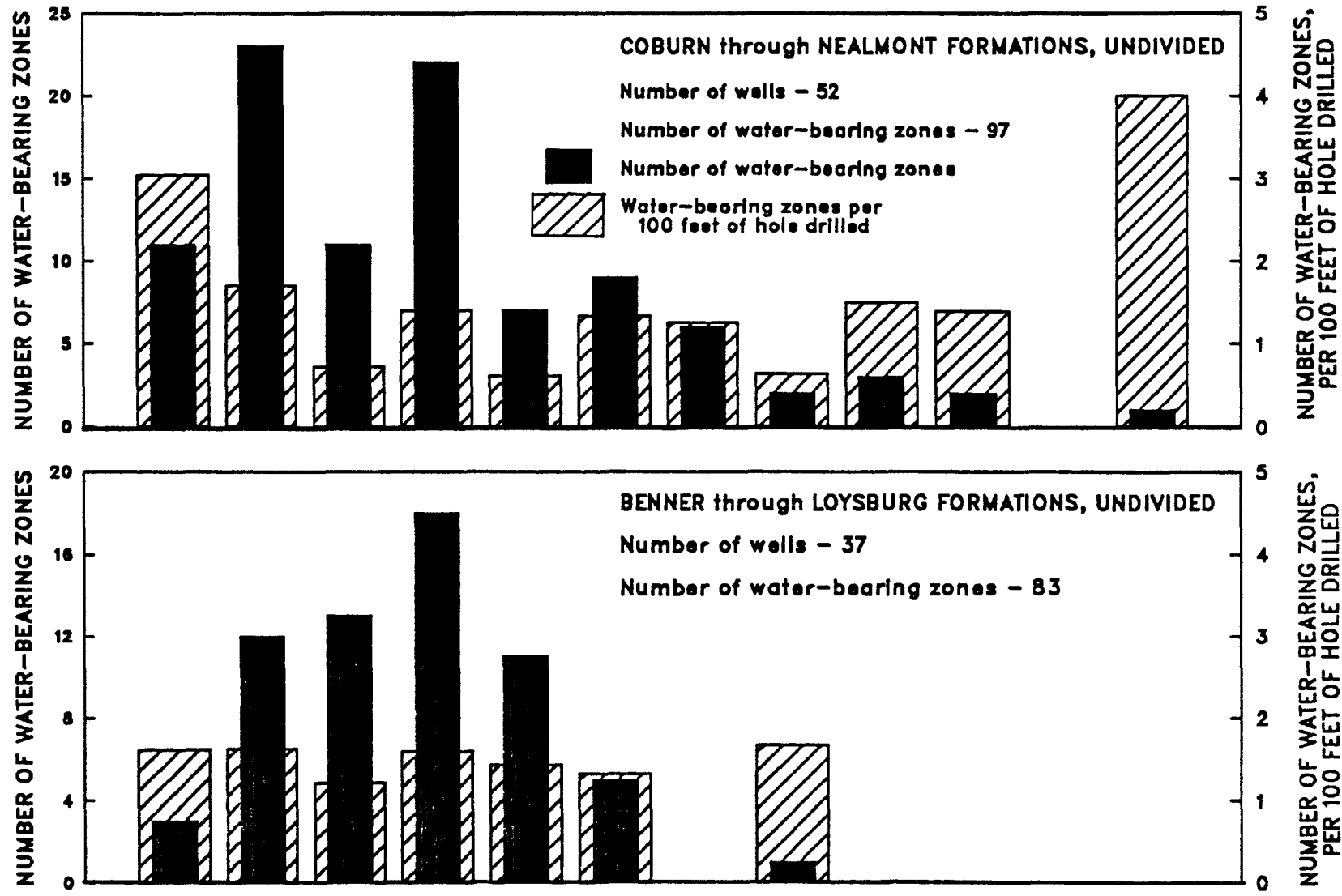

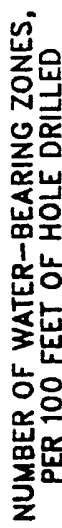

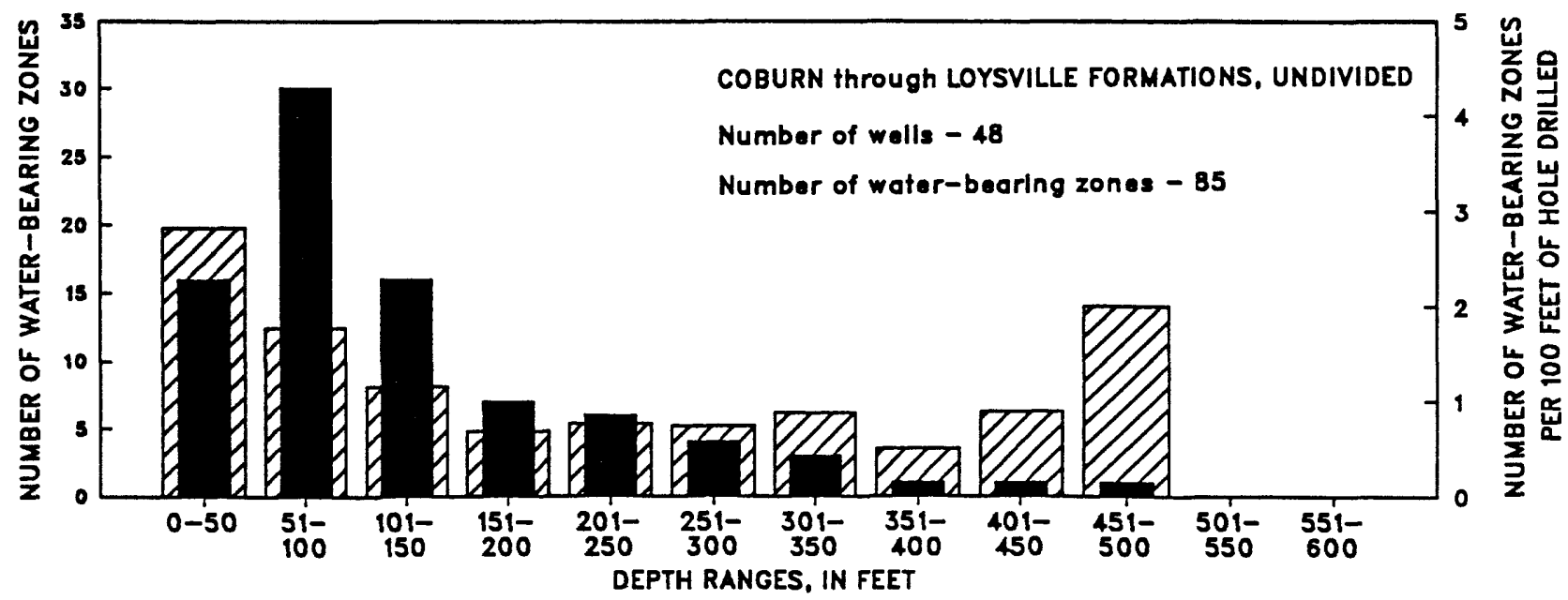

Figure 14.--Distribution of water-bearing zones in the Coburn through Loysburg Formations. 


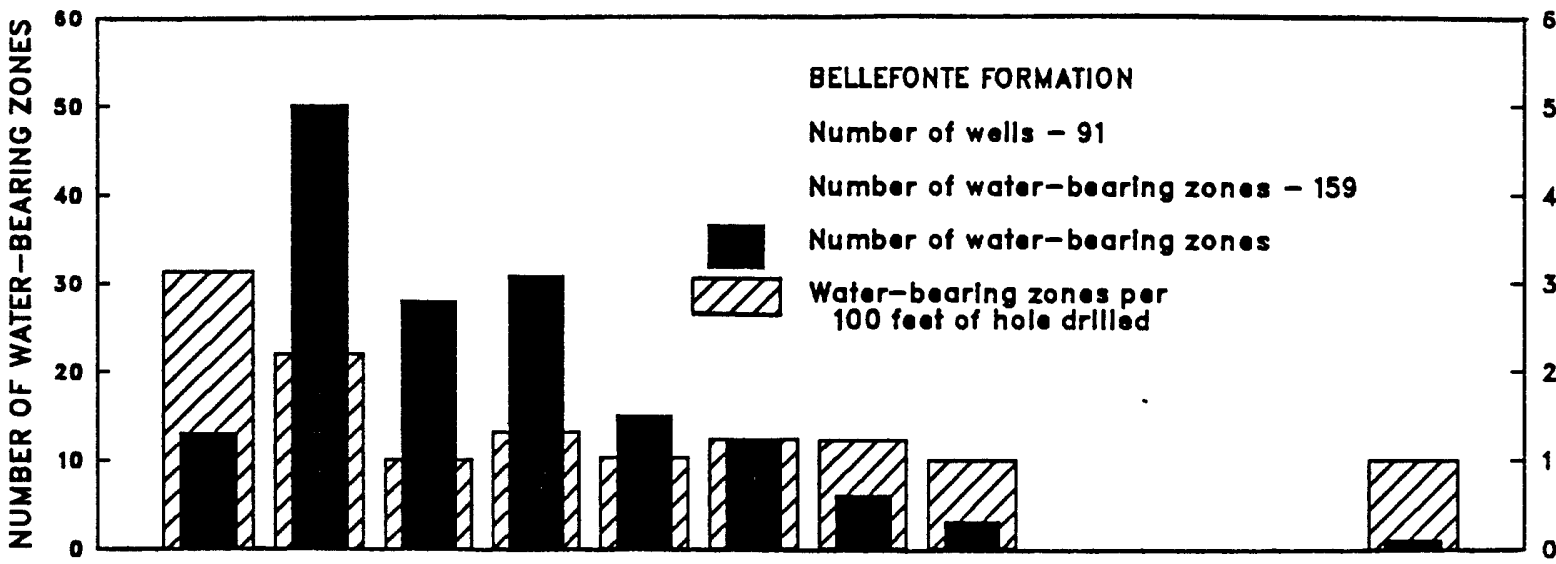

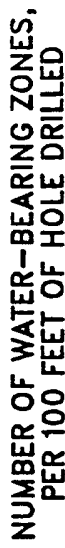

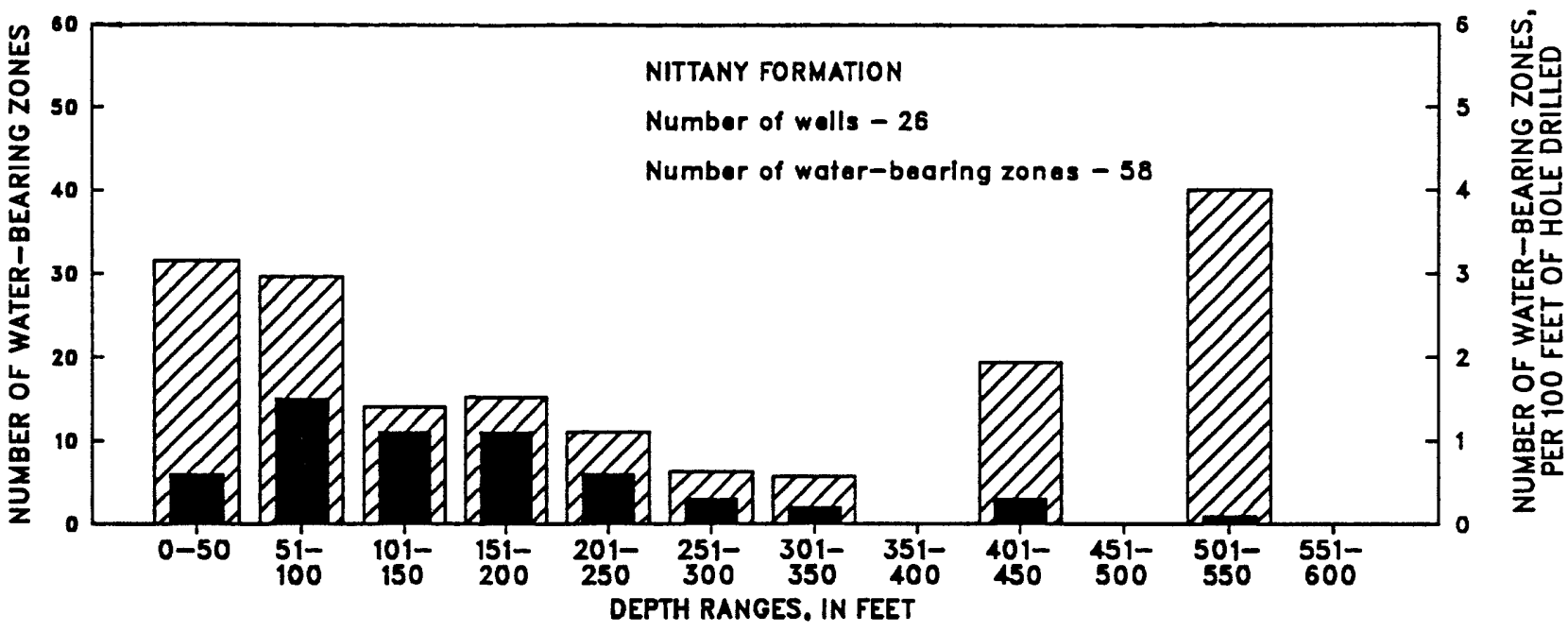

Figure 15.--Distribution of water-bearing zones in the Bellefonte and Nittany Formations. 


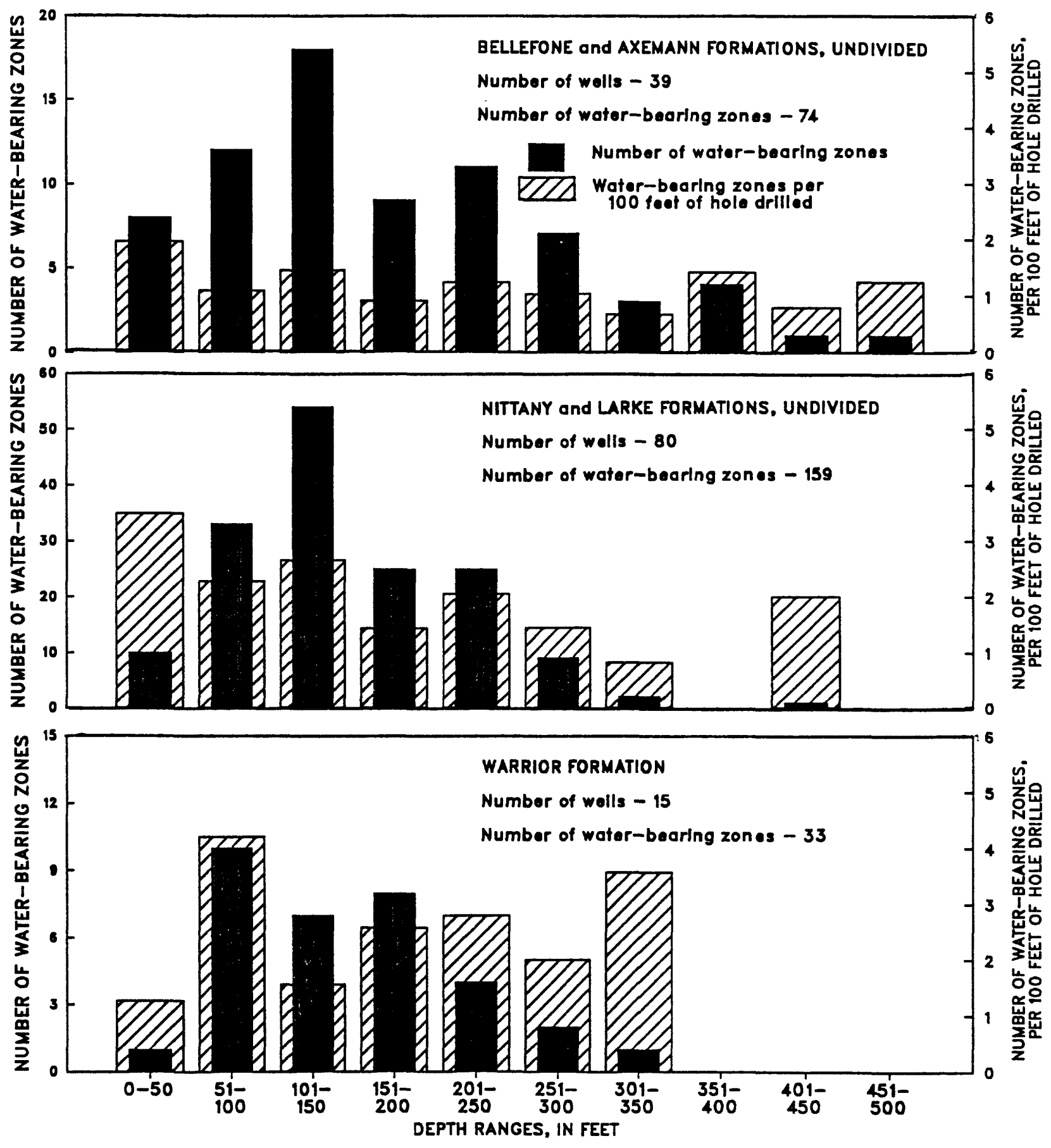

Figure 16.--Distribution of water-bearing zones in the Bellefonte and Axemann Formations, Nittany and Larke Formations and Worrior Formations. 

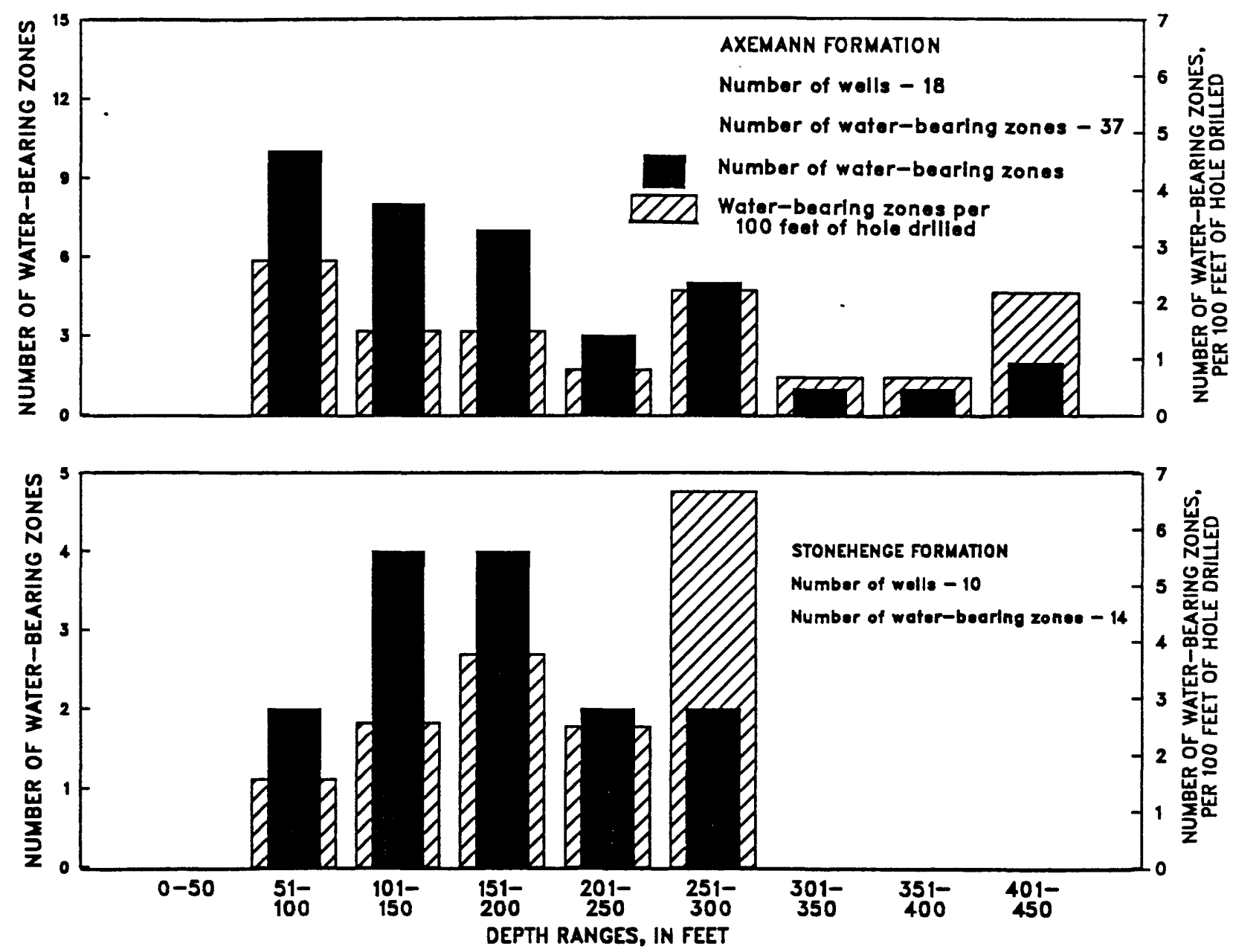

Figure 17.--Distribution of water-bearing zones in the Axemann and Stonehenge Formations. 

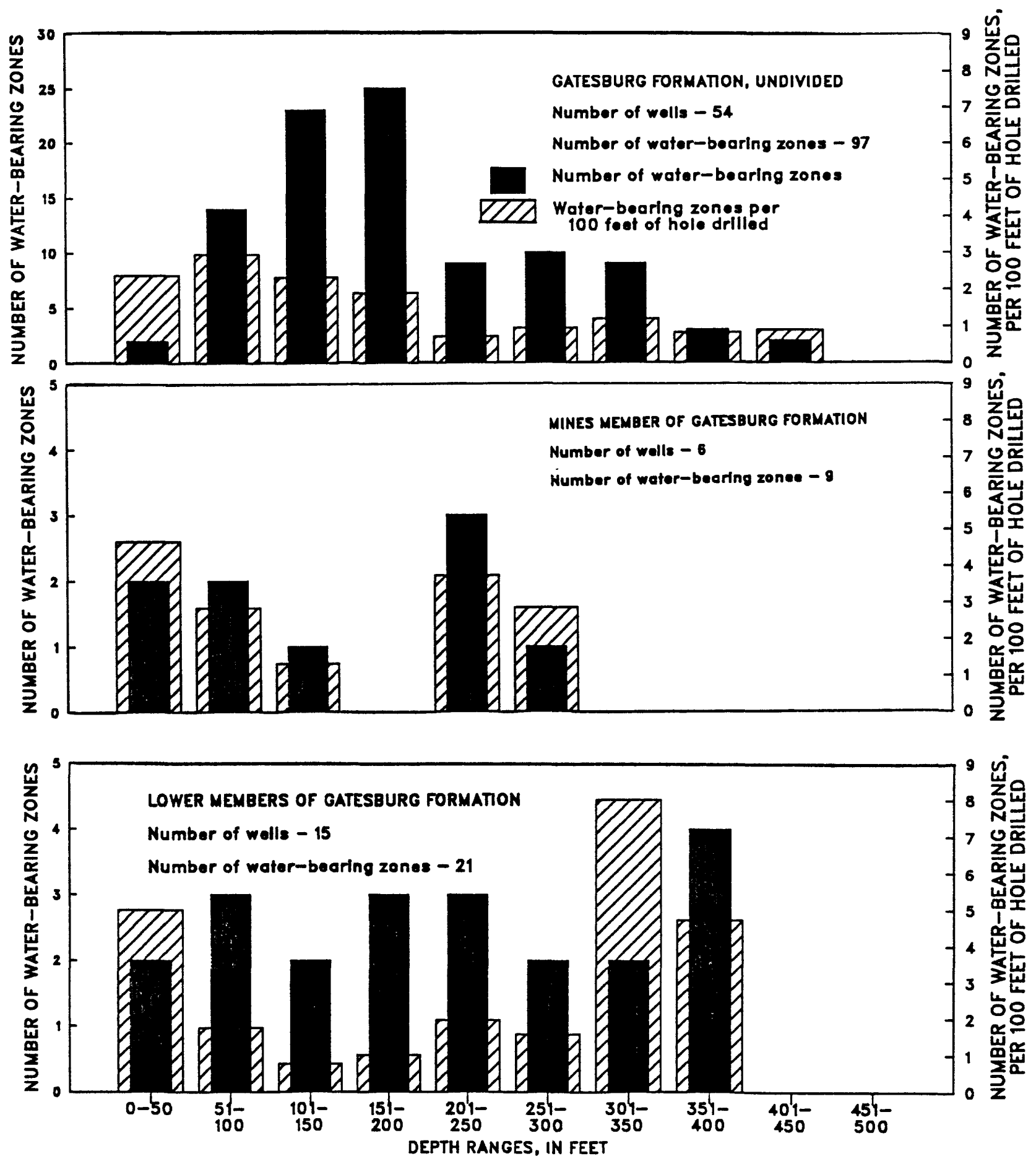

Figure 18.--Distribution of water-bearing zones in the Gatesburg Formation. 

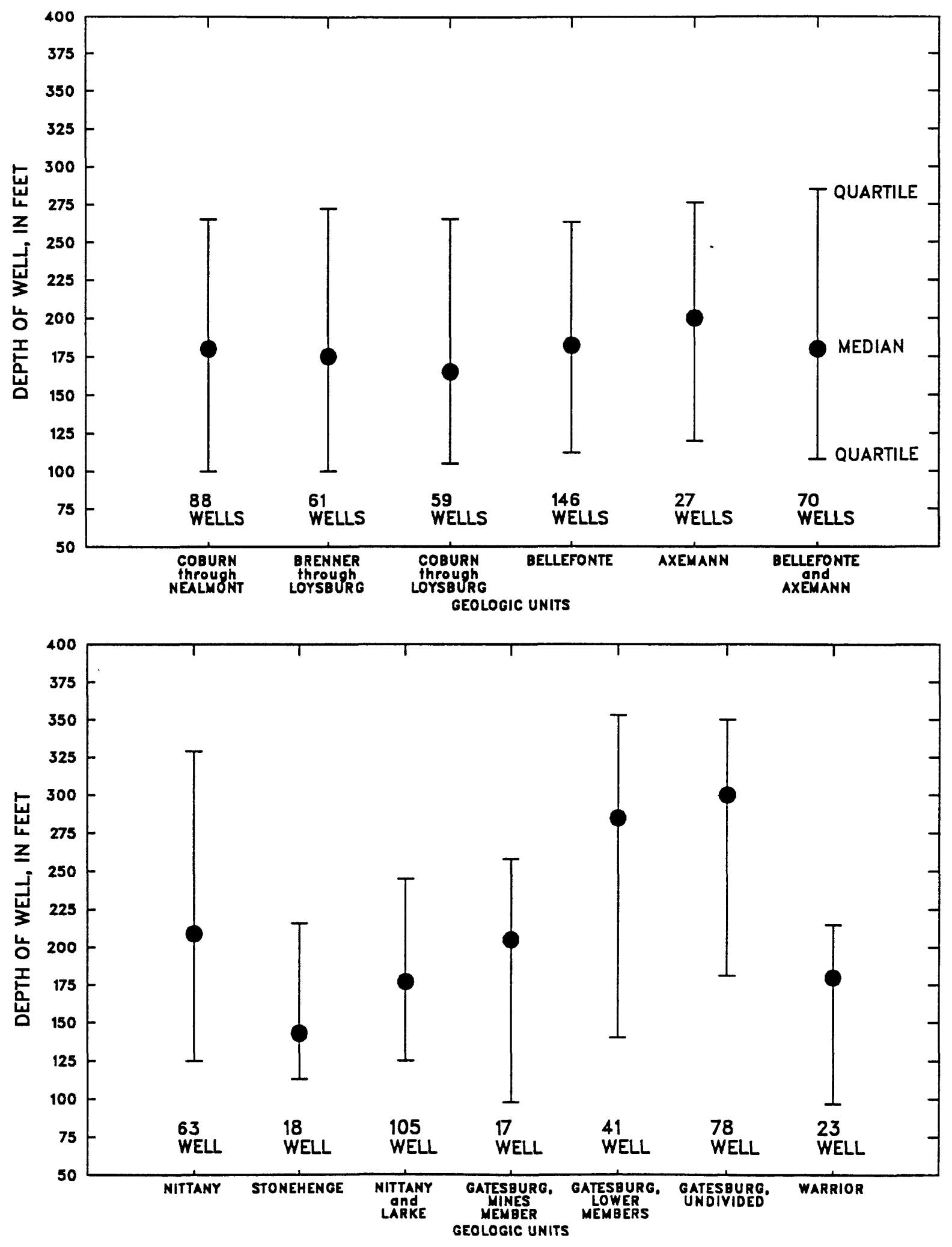

Figure 19.--Quartile values of well depths, plotted by geologic unit. 

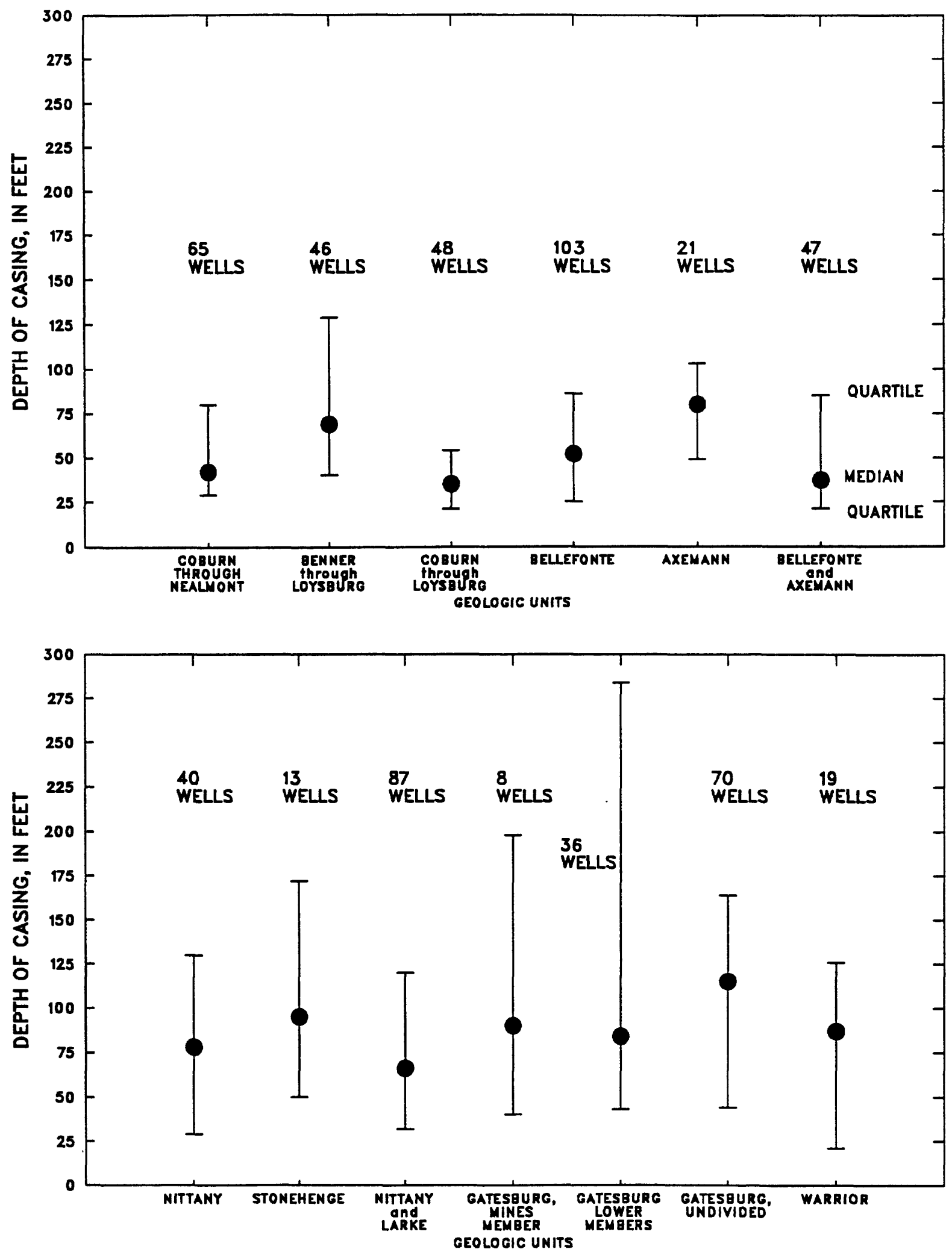

Figure 20.--Quartile values of casing depths in wells, plotted by geologic unit. 

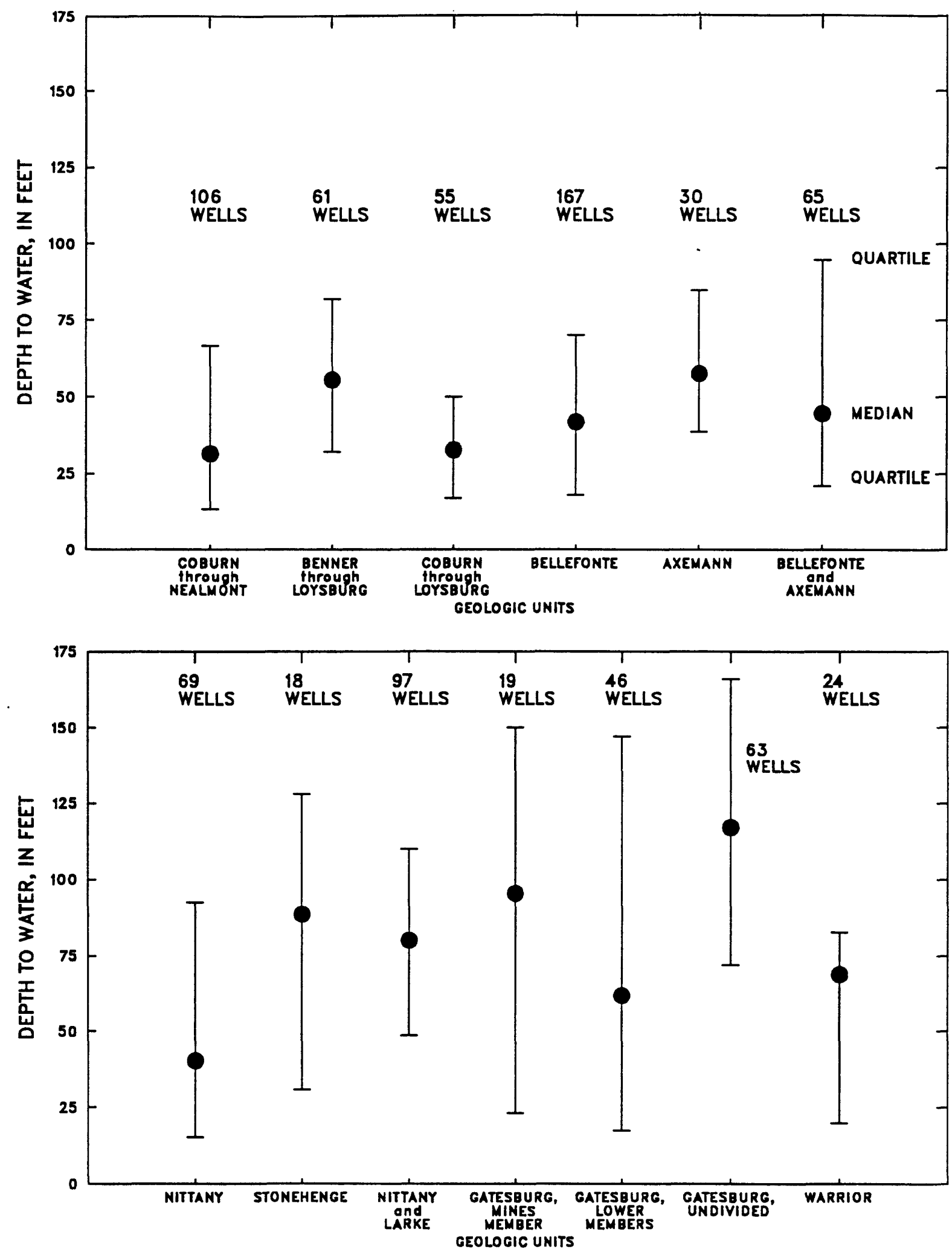

Figure 21.--Quartile values of the depth to water in wells, plotted by geologic unit. 
Rock units differ greatly in their ability to supply water to wells. Data on the effects of pumping about 250 wells were used to evaluate the water-yielding capability of the various geologic units. The results of these tests are shown in table 1 as the specific capacity of the well. The data for a common pumping period of 1 hour was analyzed to reduce the variability of drawdown in water level caused by differences in the length of time wells are pumped. No compensation was made in the data for differences in the rates of pumping. A graphic summary of the quartile and median statistics of the specific capacity data for low-production-use wells is shown by geologic unit in figure 22. A comparison of the graphs indicates that the lower members of the Gatesburg Formation have the largest potential yield and the Benner through Loysburg, Axemann, Nittany, and Nittany and Larke Formations, have large but lesser potential yields. A similar graphic summary of highproduction-use wells is shown for geologic units having sufficient data in figure 22a. A comparison of these graphs indicates results similar to the low-production-use wells.

Wells intended for high-production uses are sited and completed to maximize yield, but wells intended for low-production uses are sited and drilled to maximize convenience and minimize cost. The comparative statistics on these two general categories of use are shown in table 5 for those geologic units for which sufficient data are available. The statistics show that wells located and constructed for high-production uses will supply water at higher rates than wells intended for low-production uses. For wells in the Nittany and Gatesburg Formations, the median specific capacity of high-production-use wells is 30 to 55 times higher than that of $10 w-p r o d u c t i o n-u s e$ wells. The median specific capacities of high-production-use for wells in the lower yielding Coburn through Loysburg and Bellefonte Formations is about two to four times higher than low-production-use wells. Although the Coburn through Loysburg Formations have major conduits that transmit water from the mountain colluvium, these openings are inferred to be confined largely to shallow horizons. Otherwise, high yield wells that produce water from zones much below the zone of seasonal water table fluctuation would exist.

A comparison of the median specific capacities of all wells grouped by valleys shows a range of between 0.21 and $0.40[(\mathrm{gal} / \mathrm{min}) / \mathrm{ft}]$ with one exception. The median specific capacity of wells in the Nittany Valley is 6.4 $[(\mathrm{gal} / \mathrm{min}) / \mathrm{ft}]$. About 75 percent of the data that produced this statistic are for wells in the State College area. Here the prolific yielding Gatesburg and Nittany Formations are areally more extensive than anywhere else in these valleys, and many of the wells were sited by professional hydrogeologists. 

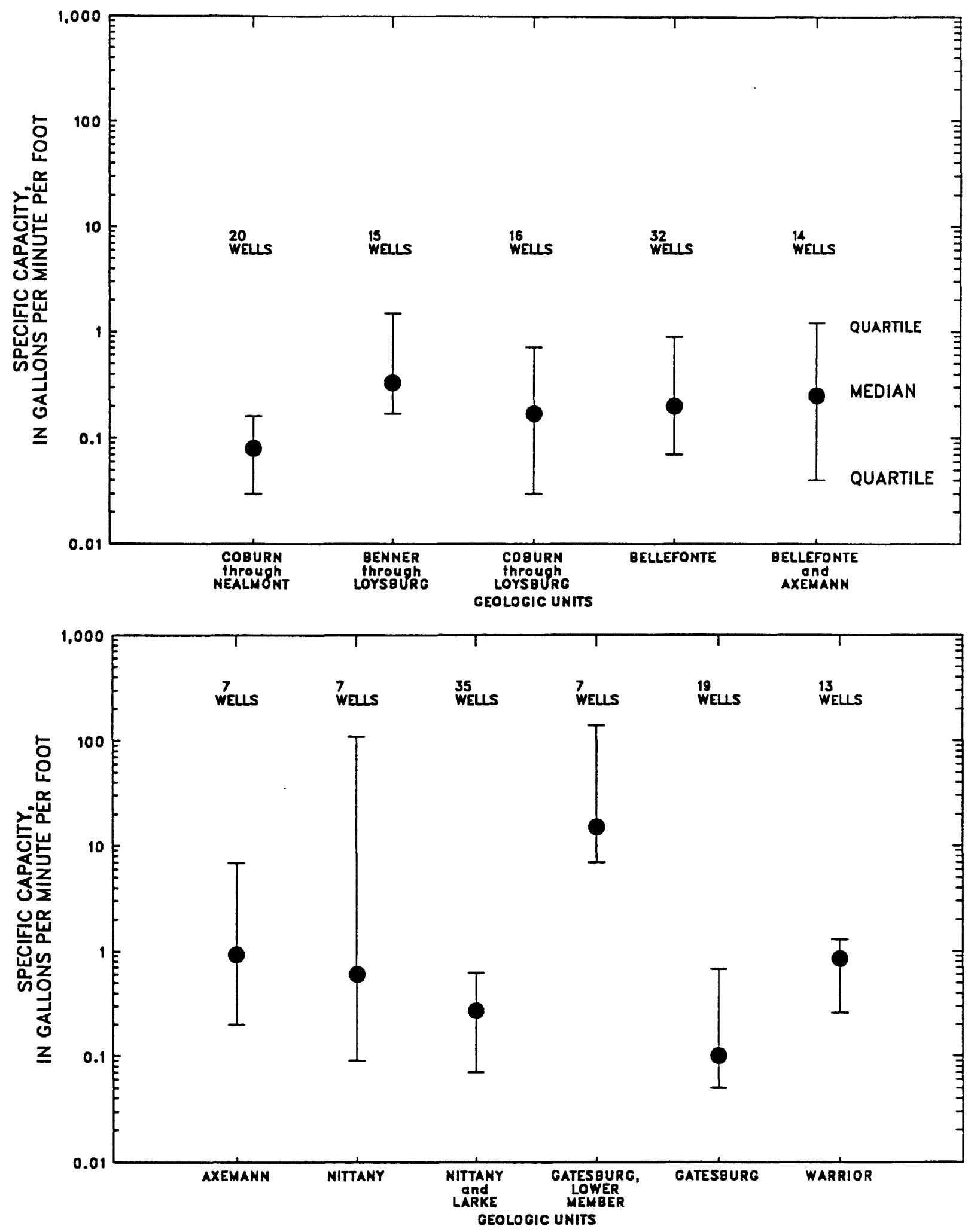

Figure 22.--Quartile values of the specific capacities of lowproduction-use wells, plotted by geologic unit. 


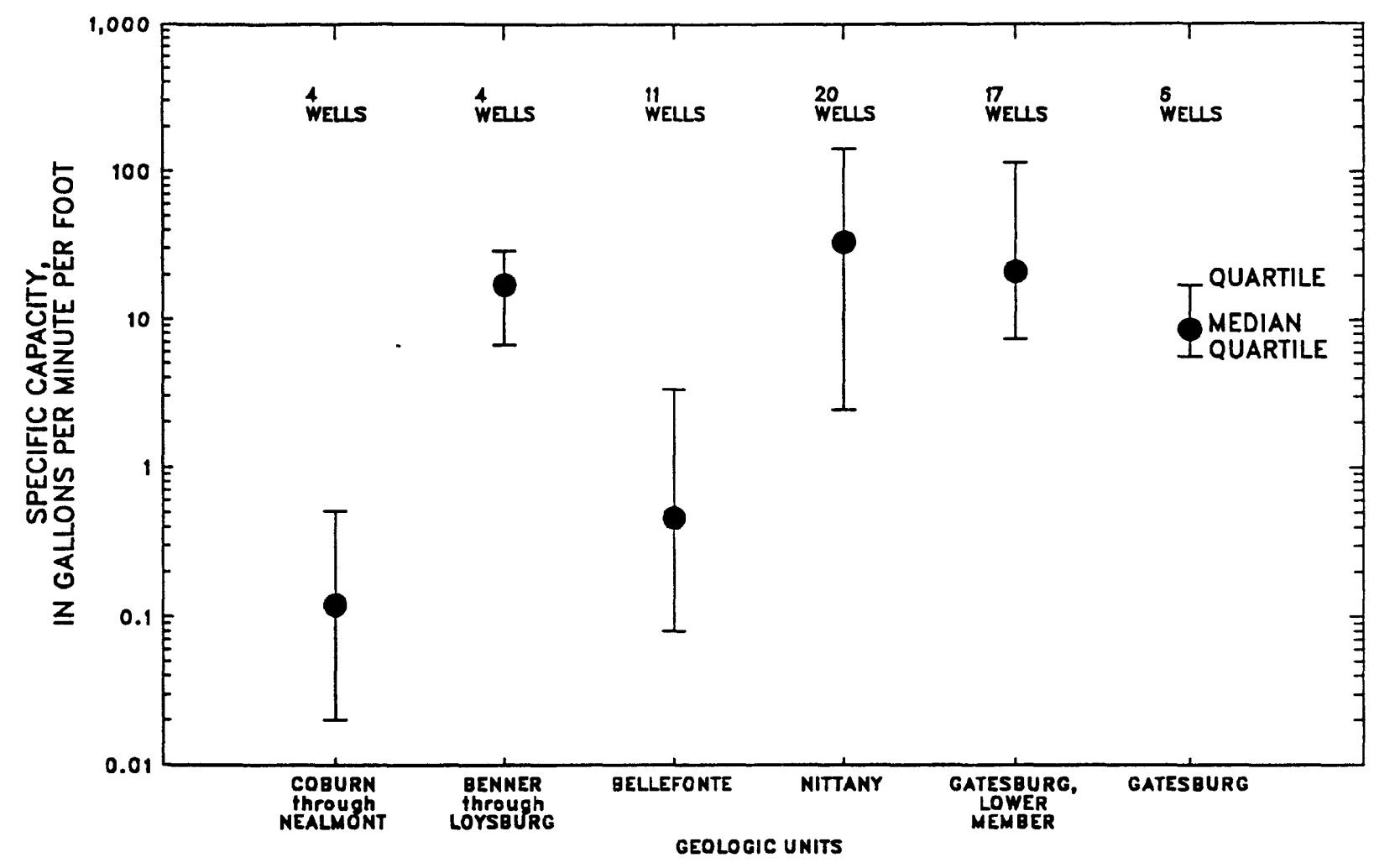

Figure 22a.--Quartile values of the specific capacities of highproduction-use wells, plotted by geologic unit. 
Table 5.--Comparison of yield and specific capacity for high- and low-production-use wells

[gal/min, gallons per minute; [(gal/min)/ft], gallons per minute per foot]

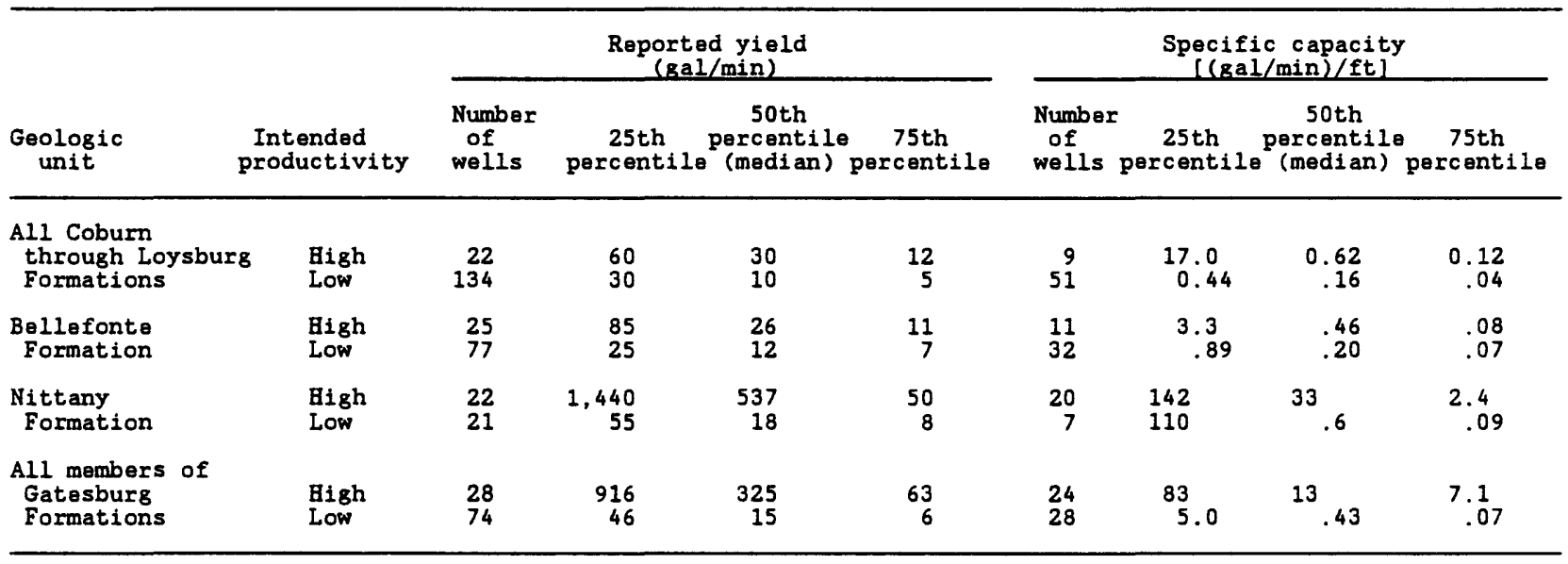

\section{Sustained Yield}

Specific-capacity statistics also can be used to estimate a sustained yield--a quantity more directly useful in selecting areas for development of high production wells. A sustained yield is defined here as the amount of water, in gallons per minute, that can be obtained continuously from a well for 24 hours. It is calculated, for each of the geologic units, by multiplying the median specific capacity for 24 hours of pumping by the available drawdown. The specific capacity after 24 hours was calculated by reducing the median 1 -hour specific capacity by the average decline in specific capacity observed in wells that were pumped for 24 hours. The average decline observed is 30 percent. The available drawdown is the difference between the median depth to water and the bottom of the depth range in which the median WBZ occurs. Table 6 summarizes the data by geologic unit. The median of yields reported by drillers on well-completion reports filed with the Pennsylvania Bureau of Topographical and Geological Survey and from other sources are shown in the last column of the table for comparison with the calculated yields. Calculated well yields equal or exceed median reported yields for all geologic units except the Coburn through Nealmont Formations. Some calculated yields are two or three times the reported median yield, but some are an order of magnitude greater. This suggests that most wells can yield more water than is reported.

The calculated sustained yields for high-production uses from the Nittany and Gatesburg Formations are biased by the preponderance of data for wells located in the vicinity of State College. Therefore, the sustained yield calculated for the Nittany is probably too high. However, high-production-use wells can be developed in other valleys in both these geologic units. 
Table 6.--Calculated sustained yields of wells in selected geologic units [gal/min, gallons per minute; [(gal/min)/ft], galions per minute per foot; ft, feet]

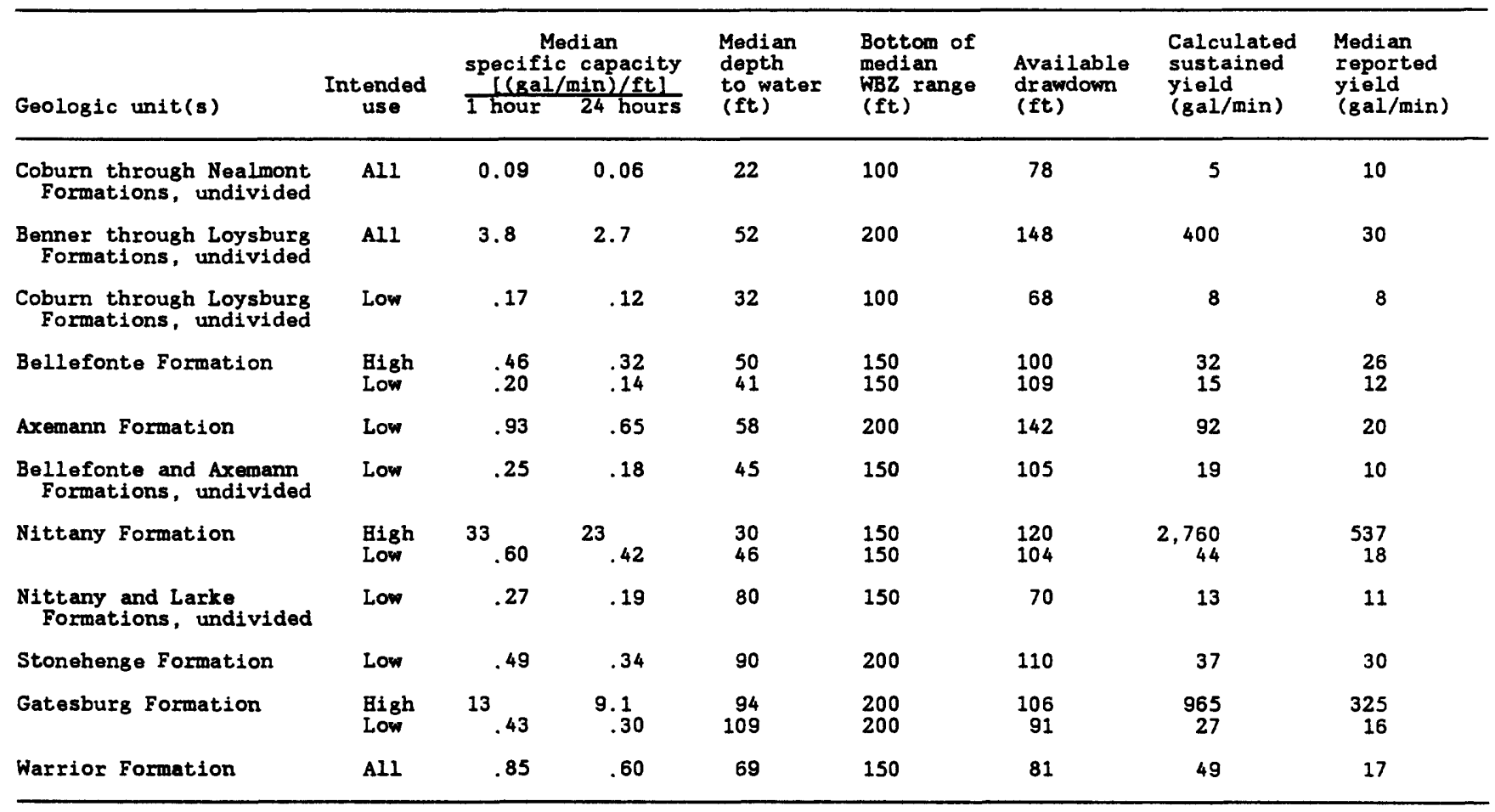

Factors that Influence the Yield of We1ls

\section{Lithology and Structure}

Lithology is the most important of all factors that influence the yield of wells. In carbonate rock, both fracture openings (bedding separations, joints, faults) and the degree of their enlargement are controlled by the type of carbonate mineral, the type and amount of noncarbonate material, rock texture, and contrasts in lithology between adjacent layers of rock. Differences in the spacing, orientation, and interconnection of openings formed by the physical stresses acting on the rocks are related to differences in lithology. Enlargement of the openings is related to both the accessibility of component minerals to water and their relative solubilities. Studies of the influence of lithology and structure on the geohydrology of carbonate rocks have been reported by many workers.

\section{Lithology}

Rauch and White (1970) in a study of cave volumes in the Coburn through Loysburg Formations of the Nittany, Penns, Brush, and Sugar Valleys found that the majority of caves are restricted to several beds in a zone about $450 \mathrm{ft}$ thick. Their study concluded that caves are formed preferentially in limestone and in limestone with low dolomite concentrations or silty streaks but rarely in dolomite. Cavity development is enhanced by small grain size and bulk rock purity. High concentrations of clay and other insolubles inhibit cavity formation. 
The work of Meisler and Becher on the relation between lithology and yield (1971, p. 49) was based on specific capacities of wells in a thick sequence of carbonate rocks in Lancaster County, Pennsylvania. They conclude that limestone has a greater yield capability than does dolomite. They also found that high concentrations of clay, silt, and sand inhibit the yield capability of carbonate rocks. A comparison of the distribution of specific capacities and the gross lithologic character of rock units in this study gives results similar to the Lancaster study, with some exceptions. The Bellefonte and Warrior Formations are dolomite units and many beds in the Coburn through Loysburg Formations contain large amounts of clay. For these formations, the specific capacity distributions are low compared to the distribution for the Axemann Formation (dominantly limestone) as shown in figures 22 and $22 \mathrm{a}$. The larger values of specific capacities in distributions for both the Nittany and Gatesburg Formations appear to be contrary to the Lancaster study findings. However, the Lancaster rocks have mixtures of clay, silt, and sand within a carbonate matrix. Both the Nittany and Gatesburg Formations have beds of carbonate-cemented sandstone interbedded with the purer dolomite beds. Removal of the cement has created a porous fabric and enlarged cavities.

\section{Structure}

Deike (1969) showed that the orientation of joints in limestone of central Pennsylvania correlate with local structure and cave passage orientations. The major and minor trends of passages for caves with more than $300 \mathrm{ft}$ of passageway are shown on cave maps published by the National Speleological Society (Speece and Cullinen, 1972 and 1975; Dayton and white, 1979; and Dayton and others, 1981). The cave locations and passage trends are shown in plates 1 and $2^{3}$. These trends can be correlated with the trends of local fracture traces to aid in selecting the best sites for drilling highproduction wells.

Fracture traces are linear features visible as tonal contrasts on aerial photographs and are attributed to vertical or near vertical fractures or zones of fracture concentration in the subsurface rock (Lattman, 1958, p. 569).

Wells drilled on fracture traces have tended to be more productive than those located at random (Lattman and Parizek, 1964; Parizek and Drew, 1966; Siddiqui, 1969; Siddiqui and Parizek, 1971; Becher and Root, 1981, p. 35-37). Many of the high-production wells used for data collection in this study were located with the aid of fracture traces. Use of fracture traces for the selection of drill sites is done best at the field location with aerial photographs. Geologic knowledge and skill in interpreting aerial photographs are needed to apply this method.

A comparison of the distributions of specific capacity and reported yield for wells located on or near faults with the distributions for all wells does not suggest that faults increase well productivity. The median specific capacities and quartiles for both distributions are virtually identical (median $0.4[(\mathrm{gal} / \mathrm{min}) / \mathrm{ft}])$ and the quartile values for reported yield actually are slightly lower for wells near or on faults than for other wells.

${ }^{3}$ Plates are on file in the U.S. Geological Survey, Pennsylvania District Library. 


\section{Topography}

Many studies (Meisler and Becher, 1971; Wood, 1980; Becher and Taylor, 1982) have evaluated the relation of topography to well yield using specificcapacity data. In general, wells in lower topographic positions have greater yields than wells in higher positions. Valleys and draws tend to form where the rocks are most susceptible to physical or chemical weathering, whereas hills form on the more resistant rocks. Openings such as bedding separations, joints, faults, fracture zones, and enlargements of these features by solution promote rapid lowering of land surface and produce topographic lows. Topographic lows are the collecting areas through which all upgradient water eventually must drain, and therefore, these low areas have the ability to transmit greater amounts of water for each unit volume of rock than do topographically higher areas.

An analysis of the relation between topography and the specific capacities of wells gave results similar to earlier studies and are shown below. The statistics are shown separately for high- and low-production uses. of the 41 high-production-use wells in the distribution, 71 percent are in topographically low areas but, of the 215 low-production-use wells, only 48 percent are in topographically low positions.

Relation of topography to median specific capacity

[No., number; MSC, median specific capacity

in gallons per minute per $\mathrm{ft}$ ]

\begin{tabular}{|c|c|c|c|c|c|c|c|c|c|c|}
\hline \multirow[t]{2}{*}{$\begin{array}{l}\text { Category } \\
\text { of use } 1\end{array}$} & \multicolumn{2}{|c|}{$\begin{array}{l}\text { Hilltop } \\
\text { wells }\end{array}$} & \multicolumn{2}{|c|}{$\begin{array}{l}\text { Hillside } \\
\text { wells }\end{array}$} & \multicolumn{2}{|c|}{$\begin{array}{l}\text { Wells in } \\
\text { undulating } \\
\text { or flat }\end{array}$} & \multicolumn{2}{|c|}{$\begin{array}{l}\text { Wells in } \\
\text { gullies } \\
\text { or draws }\end{array}$} & \multicolumn{2}{|c|}{$\begin{array}{l}\text { Valley } \\
\text { wells }\end{array}$} \\
\hline & No. & $\overline{\text { MSC }}$ & No. & MSC & No. & $\overline{M S C}$ & No. & MSC & No. & $\overline{\text { MSC }}$ \\
\hline High & 2 & 3.0 & 10 & 0.35 & 3 & 6.6 & 2 & 18.0 & 24 & 25.0 \\
\hline Low & 16 & .26 & 96 & .2 & 20 & .25 & 3 & 9.7 & 80 & .56 \\
\hline
\end{tabular}

1 High = high-production-use; Low - low-production-use.

Specific Yield

Specific yield is an estimate of the volume of water that can be obtained from a unit volume of aquifer by gravity drainage. As a unit measure of aquifer storage, it may be used to calculate the effects of ground-water development or drought on water levels. Specific yields were calculated for the zone of water-table fluctuation in the carbonate rocks of the Spring Creek and Kishacoquillas ground-water basins. The calculations were based on discharge of groundwater from the basin and the average change in ground-water levels during periods when no direct runoff was leaving the basin and no snow was on the ground. The average changes in water level were determined from continuous recording instruments on wells in carbonate rocks of the basin. These values were corrected to represent basinwide changes by using the ratio of the spring-to-fall average change in water levels for recorder wells to the average in water levels for all measured wells in the basin. 


\section{Spring Creek Basin}

An average specific yield of 0.015 was calculated for the carbonate rocks in the Spring Creek basin for four periods ranging in duration from 7 to 14 days. Each period began at least 3 days after the last rain. Specific yields for individual periods ranged from 0.013 to 0.016 ; specific yields in fall were higher than those in spring. These values agree well with more elaborate calculations made for the basin by Giddings (1974, p. 71) and the mean value agrees exactly with Giddings' mean value of 0.015 .

\section{Kishacoquillas Creek Basin}

An average specific yield of 0.017 was calculated for the carbonate rocks in the Kishacoquillas basin for eight periods ranging from 6 to 10 days in duration. The values for individual periods ranged from 0.009 to 0.038 ; the higher values prevailed in late winter.

Table 7.--Sumary of hydraulic properties and theoretical drawdowns typical of the aquifer after 180 days of pumping

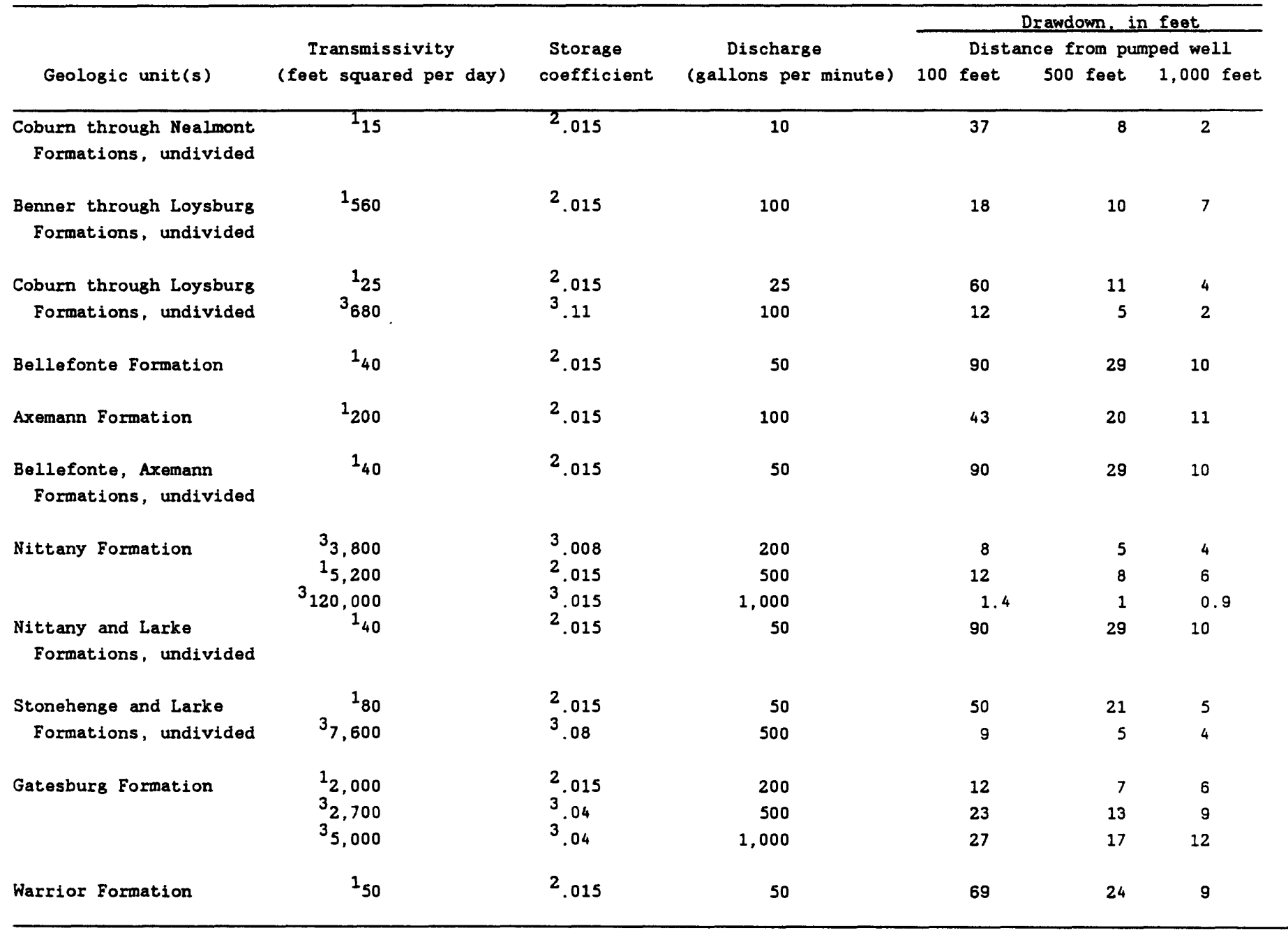

\footnotetext{
1 Based on median specific capacity data. 2 Based on specific yield.
}

3 Based on aquifer-test data at well field. 


\section{Hydraulic Characteristics and Well Interference}

Wells compete for the same water when they are too closely spaced. Overlap in drawdown reduces the yield of any well within the zone influenced by pumping from another well. In general, such well interference increases as the space between wells decreases. Drawdowns in the zone influenced by a pumped well are determined from the hydraulic properties of transmissivity and storativity for the aquifers. Table 7 summarizes transmissivities determined from aquifer tests in well fields (Moody and Assoc., 1967a,b, 1970a; State College Borough Authority, 1982) and transmissivities derived from specificcapacity data. Table 7 also gives theoretical drawdowns, based on the methods presented by Theis (1963, p. 10-15), for several of the geologic units. Storage coefficients shown are the average specific yield of 0.015 determined for the carbonate valleys or calculated from well-field aquifer tests.

Actual drawdown will differ from theoretical drawdown because of the heterogeneous nature of these aquifers and normal recharge from precipitation. In fractured-rock aquifers, interference will be greatest along some preferred direction, commonly parallel to bedding, joints, or solution features, whichever is the dominant direction of interconnection. In the carbonate valleys, the preferred direction is generally parallel to the strike of bedding and therefore to valley orientation. Local orientation can differ significantly. The ratio of strike to cross-strike transmissivity, or the anisotropy of the ground-water systems in these valleys, ranges from about 1.5 to 12 and averages about 5 on the basis of hydraulic gradients on the water table.

Table 7 can be used to estimate the spacing needed to minimize interference between wells or to estimate the effects of sustained pumping during periods of drought. Drawdowns for any discharge rate can be calculated from the table because drawdown is directly proportional to discharge.

Reducing the discharge by half will also reduce the drawdown at the well by half. However, distances calculated from pumping centers will be distorted by the anisotropy of the ground-water system.

\section{Problems Related to Water Availability}

Most problems arising from inadequacy of ground water to meet demands are local and relate generally to the yields of individual wells and not to the capability of the rocks to supply water. Wells that yield from shallow WBZs, especially those WBZs in the zone of water-table fluctuation, will probably be unable to supply demands during periods of drought. Most of these wells are used for domestic supply. Drought commonly causes a flurry of well drilling to replace or deepen such wells. Yields from wells used for public supplies commonly decline when drought lowers the water table. However, these problems can be solved by the addition of extra wells to the system, spaced sufficiently apart to reduce the likelihood of interference. 


\section{Nittany valley}

Water levels contoured on plates 1 and $2^{4}$ show a trough in the water table from pumpage only in the vicinity of Pleasant Gap. However, major well fields in the state College area pump an average of $8.1 \mathrm{Mgal} / \mathrm{d}$. On the basis of the specific yield of 0.8 [(Mgal/d)/ $\left.\mathrm{mi}^{2}\right]$ determined for the Spring Creek basin, water must be pumped from an area of $10 \mathrm{mi}^{2}$ to supply the average demand during normal recharge conditions. In droughts, the specific yield could decline to $0.45\left[(\mathrm{Mgal} / \mathrm{d}) / \mathrm{mi}^{2}\right]$ and the total area needed to supply average demands would then expand to about $18 \mathrm{mi}^{2}$. Although the total area around the several well fields that supply water exceed these area needs, pumpage levels are great enough to warrant concern for long-term effects on ground-water levels.

The hydrograph of well Ce 118, since 1984, suggests that pumpage may affect water levels in the vicinity of state College (fig. 9). This well is about $2 \mathrm{mi}$ southeast and nearly on strike with a new well field (wells Ce 652, 653, and 654) put into production in 1984 by the borough of state college. The gradient on the water-level recession for Ce 118 in 1985 is steeper than that in 1984 and the annual maximum and minimum water levels in 1985 are lower than those in 1984. Further, there was no annual rise in water level in 1986; rather, there was a gradual decline. Data for 1987 (not on graph) shows the normal annual rise and fall, but the summer high and winter low are lower than for both 1984 and 1985. The data indicates a long-term downward trend in water level that may be related to pumping. However, because Ce 118 is in the Gatesburg Formation, this trend could be related to the long lag in recharge reaching the deep ground-water system that was discussed earlier in this report.

\section{Morrison Cove}

Pumpage of about $0.14 \mathrm{Mgal} / \mathrm{d}$ from the Martinsburg Borough Authority wells has had no detectable long term effect on water levels. No trough shows in the spring water table on plate $2^{4}$ in the vicinity of pumped well $\mathrm{Ba} 330$ nor in the fall water table (not shown). The observation well $\mathrm{Ba} 329$, which is located along strike and about $255 \mathrm{ft}$ to the southeast of $\mathrm{Ba} 330$, does show some effects of the intermittent pumping of Ba 330 (fig. 23). However, the general rising trend of water level, shown on the hydrograph during the summer of 1984 for well $\mathrm{Ba} 329$, and caused by the lag in response to recharge typical of the Gatesburg Formation, may counteract the effects of pumping in the surrounding area. The hydrograph of well $\mathrm{Ba} 369$ on figure 23 in the undivided Nittany and Stonehenge Formations, about $4 \mathrm{mi}$ southwest of $\mathrm{Ba} 329$, shows the normal water level response to seasonal recharge.

4 Plates are on file in the U.S. Geological Survey, Pennsylvania District Library. 

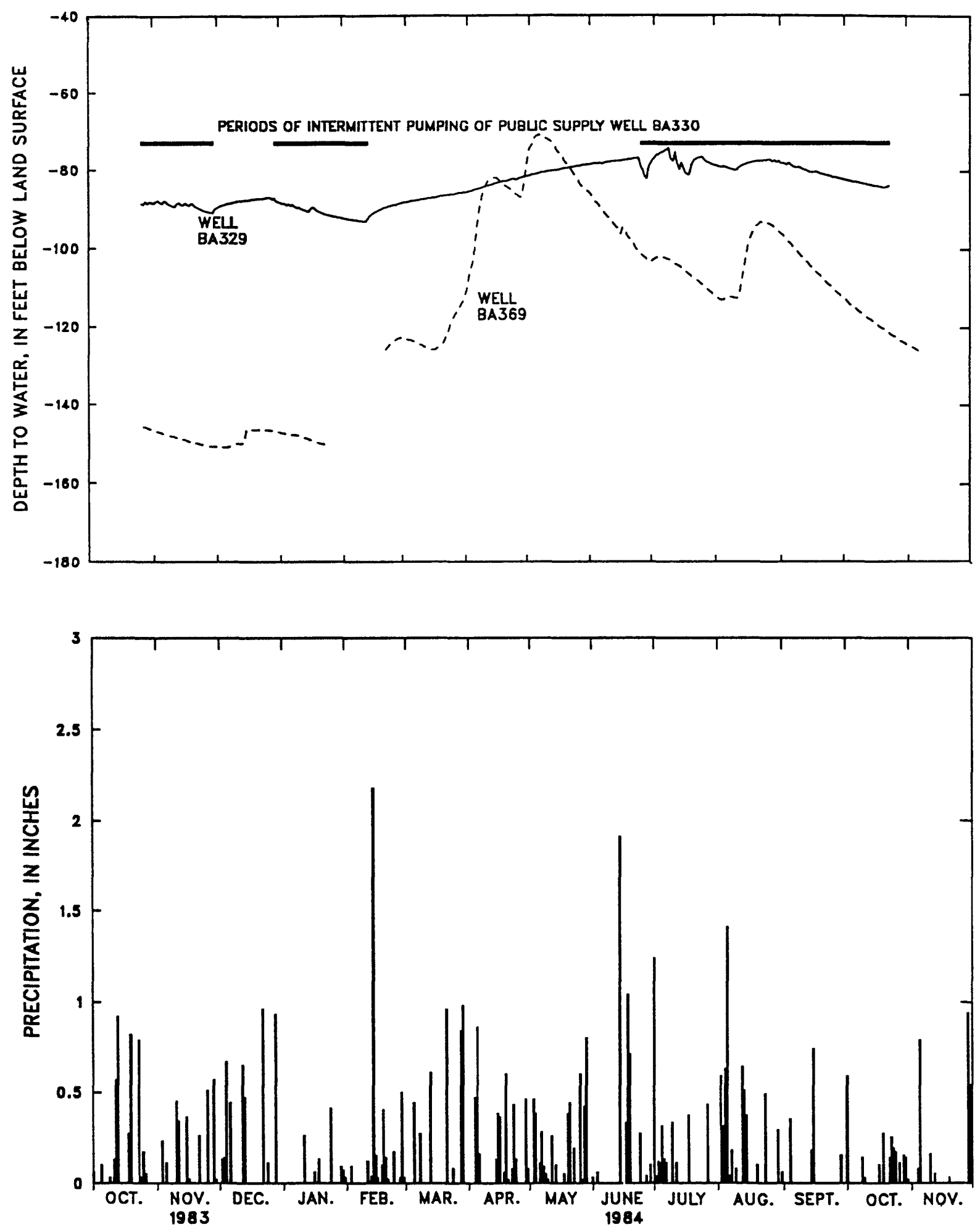

Figure 23. - Water levels in wells Ba 329 in the Gatesburg Formation and Ba 369 in the undivided Nittany and Larke Formations and precipitation at Martinsburg. Pennsylvania, October 1983 to November 1984. 


\section{Rhysical Properties}

Water in the carbonate rocks is suitable for most uses but is hard. Routine field measurements of specific conductance, hardness, and pH of well and spring water are shown in table 1 (Record of Wells) and in table 2 (Record of springs).

\section{Temperature}

Natural water temperatures range from 7 to $16.5^{\circ} \mathrm{C}$ (degrees Celsius) and vary only a few degrees annually. The temperature, its small variability, and plentiful supply in the carbonate rocks make ground water an excellent cooling and air-conditioning agent as well as a good source of geothermal heat.

\section{Specific Conductance}

A direct relation exists between specific conductance and dissolvedsolids concentration (Hem, 1970, p. 96-101). Therefore, to calculate the approximate value of dissolved solids, in milligrams per liter, for ground water in the valleys, the specific conductance can be multiplied by 0.62 . Estimates of specific conductance can be made on the basis of the specificconductance zonation maps in plates 1 and $2^{5}$.

An evaluation of the areal distribution of specific conductance in each of the valleys suggests some chemical characteristics are related to the rock unit and others are related to land use. In general, water from the Gatesburg Formation, in all valleys in which it outcrops, has a specific conductance that ranges from $250 \mu \mathrm{S} / \mathrm{cm}$ to $400 \mu \mathrm{s} / \mathrm{cm}$ (microsiemens per centimeter at $25^{\circ} \mathrm{C}$ ). These are the lowest values of specific conductance found in the carbonate rock units. Water in the Gatesburg Formation is in contact with carbonate minerals to a lesser degree than it is in other units either because much of the water moves through large conduit openings or through residuum and sandstone from which most of the carbonate minerals have been leached. The specific conductance of water from all rocks in sugar valley also is much lower there than in other valleys and ranges from 200 to $400 \mu \mathrm{S} / \mathrm{cm}$, except in one small area where greater values probably are the result of some local anthropogenic activity. Water from other rock units in all valleys has specific conductances ranging from about 400 to $700 \mu \mathrm{s} / \mathrm{cm}$. Higher values are shown on the inset maps of plates 1 and $2^{5}$ where clusters of specific conductance greater than $700 \mu \mathrm{s} / \mathrm{cm}$ were measured. These values suggest that above-normal dissolvedsolids concentrations are present and are related to contaminants entering with recharge to the ground water.

5 Plates are on file in the U.S. Geological Survey, Pennsylvania District Library. 
The more numerous pockets of specific conductance above $700 \mu \mathrm{S} / \mathrm{cm}$ seen in the Nittany Valley probably indicate that human activities are more actively contributing to increases in dissolved-solids concentrations. When human activities of man intensify, zones of elevated specific conductance will tend to coalesce as the general ground-water quality declines. Because the Nittany Valley is the most populated of the valleys in the study area, such effects should be seen there first.

In Big Cove Creek Valley, the specific conductance progressively changes from low values of 250 to $400 \mu \mathrm{S} / \mathrm{cm}$ in the northern part of the valley, and from 400 to $500 \mu \mathrm{S} / \mathrm{cm}$ at the southern end of the valley, to 600 to greater than $700 \mu \mathrm{S} / \mathrm{cm}$ near the point of water discharge from the valley. A similar change can be seen in Locke-Blacklog Valley. The specific conductance of ground water in the Kishacoquillas Valley increases progressively from the sides and ends of the valley toward the central ground-water trough that drains the valley. A zone of elevated specific conductance (greater than 700 $\mu \mathrm{S} / \mathrm{cm}$ ) follows the ground-water trough. The valley is largely agricultural in character, and these elevated values of specific conductance are likely caused by farming practices.

\section{Chemical Characteristics}

$\mathrm{pH}$

The median $\mathrm{pH}$ of ground water (a measure of acidity or alkalinity) is 7.4 , but $\mathrm{pH}$ ranges from 6.2 to 9.5. Most of the ground water has a $\mathrm{pH}$ greater than 7.0 , the value of a neutral water. The higher the $\mathrm{pH}$, the greater the alkalinity of water. The median $\mathrm{pH}$ of 7.6 in water from the Gatesburg Formation is slightly higher than that in other geologic units.

\section{Hardness}

Hardness is a property of water that causes the formation of an insoluble residue when the water is used with soap. It is primarily caused by the presence of calcium and magnesium ions. Durfor and Becker (1964, p. 27) classified the degree of hardness as follows:

\begin{tabular}{ll}
$\begin{array}{l}\text { Hardness range } \\
\text { (milligrams per }\end{array}$ & \\
1iter of $\mathrm{CaCO}_{3}$ ) & Description \\
\hline $0-60$ & Soft \\
$61-120$ & Moderately hard \\
$121-180$ & Hard \\
Greater than 180 & Very hard
\end{tabular}

High hardness is undesirable for some uses of water because it forms scale on pipes and in boilers, and a curd in combination with soap. 
Ground water in the carbonate rocks ranges from moderately hard to very hard. The median hardness of water from 550 wells is $205 \mathrm{mg} / \mathrm{L}$. In general, hardness and specific conductance are directly related in carbonate rocks because calcium and magnesium bicarbonate comprise most of the dissolved mineral content.

The statistical distribution of hardness is shown in figure 24 for each of the geologic units and in figure 25 for all the valleys. Hardness of water changes progressively from the comparatively low values in the younger carbonate formations that border most valleys to the comparatively high values shown in most older carbonate formations that outcrop in central parts of most valleys. However, the median hardness of $137 \mathrm{mg} / \mathrm{L}$ in water from the Gatesburg Formation is the lowest value found in any of the carbonate rocks for reasons given in the discussion of specific conductance. Water moves too quickly through the fracture and conduit openings in the valleys for chemical equilibrium to be attained between solution and precipitation of carbonate minerals. The studies of Langmuir (1971) showed that less than 25 percent of the well and spring water in central Pennsylvania carbonate rocks had reached equilibrium with the host minerals calcite and dolomite.

\section{Major Ions}

Results of laboratory analyses of the major chemical constituents in water from 126 wells and 24 springs in the carbonate rocks are reported in table 8. Of the 150 analyses, 109 were done for this study on samples collected in July and August 1984 and in June, July, and August 1985, and the remainder for reconnaissance studies in 1980 and 1981 by Taylor and others (1982, 1985). Table 9 shows the maximum, minimum, and median values of each chemical constituent from each geologic unit that has at least four analyses. Values reported as < (less than) in table 8 were arbitrarily divided by two for the calculation of medians for iron and manganese distributions in table 9.

The MCLs and SMCLs established by USEPA (1986a and 1986b) for four constituents in drinking water are exceeded in several analyses. The SMCLs for iron, manganese, and dissolved solids are aesthetic goals and do not have health implications, but the MCL for nitrate in public supply systems is related to health. High nitrate content may be life-threatening, as concentrations in excess of $10 \mathrm{mg} / \mathrm{L}$ are known to cause methemoglobinemia, commonly called "blue baby disease", in infants. 

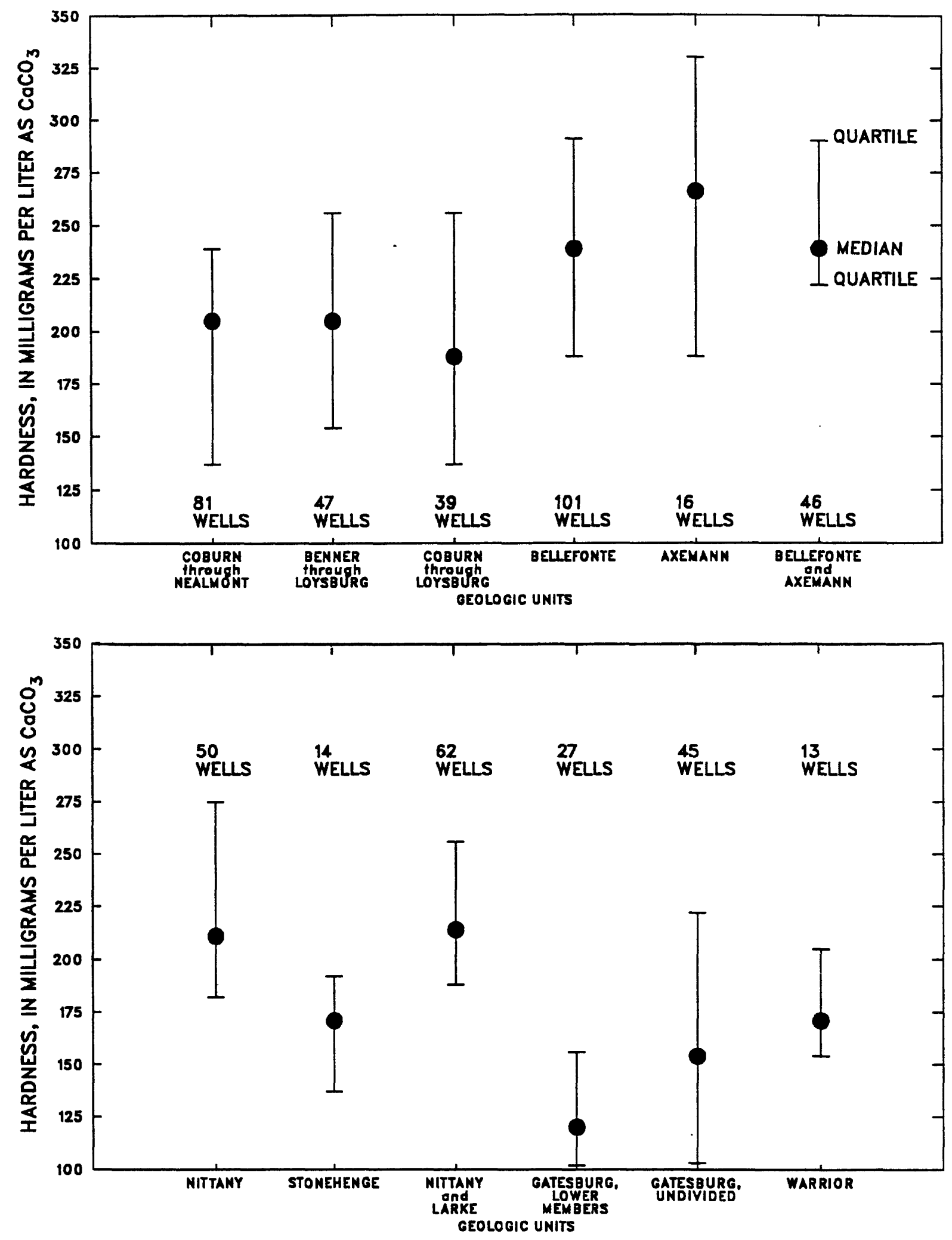

Figure 24.--Quartile values of hardness as $\mathrm{CaCO}_{3}$ in wells, plotted by geologic unit. 


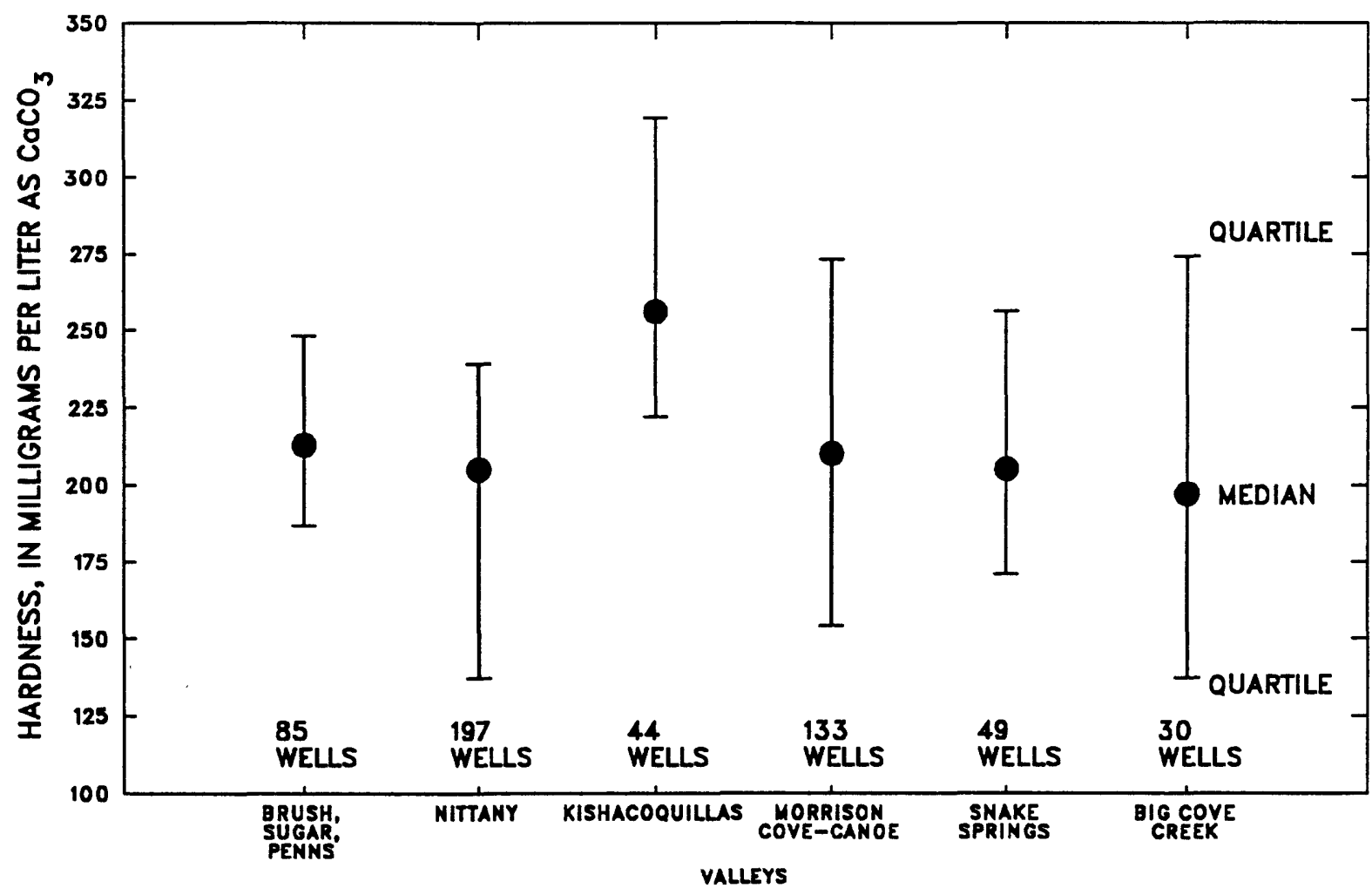

Figure 25.--Quartile values of hardness as $\mathrm{CaCO}_{3}$ in wells, plotted by valley. 
Table 8.--Chemical analyses of major constituents in well and spring water [ $\mu \mathrm{g} / \mathrm{L}$, micrograms per liter; mg/L, milligrams per liter; <, less than; 'C, degrees Celsius; --, no data]

\begin{tabular}{|c|c|c|c|c|c|c|c|c|c|c|c|}
\hline $\begin{array}{l}\text { County } \\
\text { well or } \\
\text { spring } \\
\text { number }\end{array}$ & Date & $\begin{array}{l}\text { Geo- } \\
\text { logiç } \\
\text { unit }\end{array}$ & $\begin{array}{c}\text { Temper- } \\
\text { ature } \\
\left({ }^{\circ} \mathrm{C}\right)\end{array}$ & $\begin{array}{l}\text { Iron, } \\
\text { dis- } \\
\text { solved } \\
(\mu g / L \\
\text { as } \mathrm{Fe})\end{array}$ & $\begin{array}{l}\text { Manga- } \\
\text { nese, } \\
\text { dis- } \\
\text { solved } \\
(\mu g / L \\
\text { as } M \text { ) }\end{array}$ & $\begin{array}{l}\text { Calcium, } \\
\text { dis- } \\
\text { solved } \\
(\mathrm{mg} / \mathrm{L} \\
\text { as } \mathrm{Ca})\end{array}$ & $\begin{array}{l}\text { Magne- } \\
\text { sium, } \\
\text { dis- } \\
\text { solved } \\
\text { (mg/L } \\
\text { as Mg) }\end{array}$ & $\begin{array}{l}\text { Sodium, } \\
\text { dis- } \\
\text { solved } \\
\text { (mg/L } \\
\text { as } \mathrm{Na} \text { ) }\end{array}$ & $\begin{array}{l}\text { Potas- } \\
\text { sium, } \\
\text { dis- } \\
\text { solved } \\
\text { (mg/L } \\
\text { as K) }\end{array}$ & $\begin{array}{l}\text { Alka- } \\
\text { linity, } \\
\text { lab } \\
\text { (mg/L } \\
\text { as } \mathrm{CaCO}_{3} \text { ) }\end{array}$ & $\begin{array}{l}\text { Chlo- } \\
\text { ride, } \\
\text { dis- } \\
\text { solved } \\
\text { (mg/L } \\
\text { as Cl) }\end{array}$ \\
\hline
\end{tabular}

\begin{tabular}{|c|c|c|c|c|c|c|c|c|c|c|c|}
\hline \multirow[b]{2}{*}{$\begin{array}{l}310 \\
314 \\
317 \\
389 \\
489\end{array}$} & \multicolumn{11}{|c|}{ Bedford County } \\
\hline & $\begin{array}{l}08-20-80 \\
08-20-80 \\
08-21-80 \\
08-27-80 \\
09-18-80\end{array}$ & $\begin{array}{l}\text { Oba } \\
\text { Oba } \\
C_{w} \\
C_{g} \\
C_{g}\end{array}$ & $\begin{array}{c}11.5 \\
14.0 \\
-0 \\
14.0 \\
12.0\end{array}$ & $\begin{array}{l}30 \\
20 \\
90 \\
20 \\
10\end{array}$ & $\begin{array}{l}10 \\
10 \\
10 \\
10 \\
10\end{array}$ & $\begin{array}{l}96 \\
70 \\
38 \\
40 \\
51\end{array}$ & $\begin{array}{l}36 \\
21 \\
21 \\
17 \\
28\end{array}$ & $\begin{array}{c}5.7 \\
25 \\
9.0 \\
1.2 \\
0.5\end{array}$ & $\begin{array}{l}5.7 \\
4.3 \\
2.0 \\
1.2 \\
0.8\end{array}$ & $\begin{array}{l}360 \\
290 \\
170 \\
190 \\
240\end{array}$ & $\begin{array}{r}18 \\
33 \\
20 \\
4.0 \\
1.0\end{array}$ \\
\hline $\begin{array}{l}502 \\
508 \\
515 \\
525 \\
530\end{array}$ & $\begin{array}{l}08-14-84 \\
08-13-84 \\
08-14-84 \\
08-15-84 \\
08-13-84\end{array}$ & $\begin{array}{l}\text { Obf } \\
\text { Onl } \\
\text { Ocl } \\
\text { Onl } \\
\text { Obf }\end{array}$ & $\begin{array}{l}12.0 \\
12.0 \\
12.0 \\
11.0 \\
12.5\end{array}$ & $\begin{array}{r}<100 \\
490 \\
<100 \\
<100 \\
<100\end{array}$ & $\begin{array}{l}<50 \\
<50 \\
<50 \\
<50 \\
---\end{array}$ & $\begin{array}{l}61 \\
73 \\
83 \\
26 \\
48\end{array}$ & $\begin{array}{l}36 \\
42 \\
35 \\
25 \\
30\end{array}$ & $\begin{array}{r}5.2 \\
48 \\
3.3 \\
2.5 \\
1.1\end{array}$ & $\begin{array}{r}11 \\
2.1 \\
.9 \\
1.2 \\
1.0\end{array}$ & $\begin{array}{l}258 \\
266 \\
220 \\
168 \\
184\end{array}$ & $\begin{array}{c}14 \\
110 \\
16 \\
7.2 \\
10\end{array}$ \\
\hline $\begin{array}{l}531 \\
539 \\
555 \\
568 \\
574\end{array}$ & $\begin{array}{l}08-15-84 \\
08-14-84 \\
08-15-84 \\
08-14-84 \\
08-15-84\end{array}$ & $\begin{array}{l}\text { Cw } \\
\text { Onl } \\
C_{8} \\
\text { Ocl } \\
\text { Obf }\end{array}$ & $\begin{array}{l}13.0 \\
19.0 \\
12.0 \\
12.0 \\
13.0\end{array}$ & $\begin{array}{r}130 \\
<100 \\
<100 \\
<100 \\
<100\end{array}$ & $\begin{array}{l}<50 \\
<50 \\
<50 \\
<50 \\
<50\end{array}$ & $\begin{array}{l}45 \\
57 \\
69 \\
70 \\
48\end{array}$ & $\begin{array}{c}28 \\
36 \\
33 \\
5.6 \\
30\end{array}$ & $\begin{array}{l}.7 \\
1.9 \\
1.1 \\
7 \cdot 9 \\
2.3\end{array}$ & $\begin{array}{r}1.4 \\
1.1 \\
.9 \\
.9 \\
.9\end{array}$ & $\begin{array}{l}210 \\
272 \\
284 \\
174 \\
204\end{array}$ & $\begin{array}{r}2.8 \\
4.0 \\
4.0 \\
20 \\
8.8\end{array}$ \\
\hline $\begin{array}{l}592 \\
608 \\
621 \\
629 \\
633\end{array}$ & $\begin{array}{l}08-23-84 \\
08-23-84 \\
08-23-84 \\
08-14-84 \\
08-23-84\end{array}$ & $\begin{array}{l}\text { Ocl } 1 \\
\mathrm{Cg}_{\mathrm{g}} \\
\text { Oba } \\
\text { Onl } \\
\mathrm{Cg}_{\mathrm{g}}\end{array}$ & $\begin{array}{l}11.0 \\
12.0 \\
12.0 \\
13.5 \\
14.0\end{array}$ & $\begin{array}{r}150 \\
<100 \\
<100 \\
<100 \\
<100\end{array}$ & $\begin{array}{l}<50 \\
<50 \\
<50 \\
<50 \\
<50\end{array}$ & $\begin{array}{l}-- \\
-- \\
-- \\
56 \\
--\end{array}$ & $\begin{array}{l}-- \\
-- \\
-- \\
29 \\
--\end{array}$ & $\begin{array}{l}-- \\
-- \\
-- \\
2.6 \\
--\end{array}$ & $\begin{array}{l}-- \\
-- \\
-- \\
1.7 \\
--\end{array}$ & $\begin{array}{r}124 \\
224 \\
310 \\
206 \\
96\end{array}$ & $\begin{array}{l}14 \\
7.0 \\
51 \\
11 \\
4.0\end{array}$ \\
\hline \multirow[t]{2}{*}{$\begin{array}{l}640 \\
\text { SP26 } \\
\text { SP27 }\end{array}$} & $\begin{array}{l}08-14-84 \\
07-31-85 \\
08-01-85\end{array}$ & $\begin{array}{l}\text { Ocl } \\
\text { Onl } \\
\epsilon_{8}\end{array}$ & $\begin{array}{l}13.0 \\
11.0 \\
11.0\end{array}$ & $\begin{array}{l}370 \\
<10 \\
<10\end{array}$ & $\begin{array}{l}<50 \\
<10 \\
<10\end{array}$ & $\begin{array}{l}19 \\
41 \\
37\end{array}$ & $\begin{array}{l}9.2 \\
21 \\
18\end{array}$ & $\begin{array}{r}65 \\
1.6 \\
1.0\end{array}$ & $\begin{array}{r}1.4 \\
.59 \\
.64\end{array}$ & $\begin{array}{l}200 \\
164 \\
152\end{array}$ & $\begin{array}{r}20 \\
7.0 \\
5.0\end{array}$ \\
\hline & \multicolumn{11}{|c|}{ Blair County } \\
\hline $\begin{array}{l}150 \\
223 \\
248 \\
254 \\
270\end{array}$ & $\begin{array}{l}06-04-80 \\
06-10-80 \\
06-11-80 \\
06-16-80 \\
07-02-80\end{array}$ & $\begin{array}{l}\mathrm{Cg} \\
\text { Oba } \\
\text { Onl } \\
\text { Cgm } \\
\text { Oba }\end{array}$ & $\begin{array}{l}11.0 \\
11.5 \\
14.0 \\
14.0 \\
13.0\end{array}$ & $\begin{array}{r}30 \\
30 \\
20 \\
340 \\
<10\end{array}$ & $\begin{array}{l}-- \\
-- \\
10 \\
30 \\
--\end{array}$ & $\begin{array}{l}45 \\
60 \\
40 \\
48 \\
78\end{array}$ & $\begin{array}{c}26 \\
36 \\
22 \\
3.6 \\
43\end{array}$ & $\begin{array}{l}5.0 \\
1.7 \\
1.9 \\
1.2 \\
2.2\end{array}$ & $\begin{array}{r}.3 \\
.4 \\
.9 \\
.2 \\
1.0\end{array}$ & $\begin{array}{l}250 \\
260 \\
190 \\
140 \\
320\end{array}$ & $\begin{array}{l}3.0 \\
7.0 \\
7.0 \\
3.0 \\
2.0\end{array}$ \\
\hline $\begin{array}{l}272 \\
297 \\
298 \\
361 \\
362\end{array}$ & $\begin{array}{l}07-02-80 \\
07-08-80 \\
07-08-80 \\
07-09-80 \\
07-09-80\end{array}$ & $\begin{array}{l}\text { Onl } \\
\text { Onl } \\
\text { Oba } \\
\text { Ocl } \\
\mathrm{Cg}_{\mathrm{g}}\end{array}$ & $\begin{array}{l}11.0 \\
18.0 \\
11.0 \\
11.0 \\
11.0\end{array}$ & $\begin{array}{r}130 \\
20 \\
200 \\
40 \\
170\end{array}$ & $\begin{array}{l}-- \\
-- \\
20 \\
10 \\
10\end{array}$ & $\begin{array}{l}46 \\
46 \\
62 \\
56 \\
50\end{array}$ & $\begin{array}{l}26 \\
21 \\
21 \\
1.5 \\
20\end{array}$ & $\begin{array}{r}1.9 \\
.8 \\
2.9 \\
1.7\end{array}$ & $\begin{array}{l}1.0 \\
1.0 \\
1.0 \\
1.0 \\
1.0\end{array}$ & $\begin{array}{l}200 \\
170 \\
250 \\
140 \\
220\end{array}$ & $\begin{array}{r}4.0 \\
12.0 \\
4.0 \\
5.0 \\
5.0\end{array}$ \\
\hline $\begin{array}{l}390 \\
394 \\
402 \\
407 \\
423\end{array}$ & $\begin{array}{l}08-21-84 \\
07-21-84 \\
08-21-84 \\
08-21-84 \\
08-20-84\end{array}$ & $\begin{array}{l}\text { Obf } \\
\text { Oba } \\
\epsilon_{8} \\
C_{g} \\
O n 1\end{array}$ & $\begin{array}{l}11.0 \\
12.5 \\
13.0 \\
14.0 \\
13.0\end{array}$ & $\begin{array}{r}<100 \\
210 \\
280 \\
<100 \\
210\end{array}$ & $\begin{array}{l}<50 \\
<50 \\
<50 \\
<50 \\
<50\end{array}$ & $\begin{array}{l}63 \\
72 \\
13 \\
-- \\
9.0\end{array}$ & $\begin{array}{l}38 \\
45 \\
7.6 \\
-- \\
32\end{array}$ & $\begin{array}{c}2.1 \\
1.9 \\
1.4 \\
27^{---}\end{array}$ & $\begin{array}{r}1.1 \\
1.4 \\
1.2 \\
-. \\
--\end{array}$ & $\begin{array}{r}236 \\
298 \\
56 \\
130 \\
296\end{array}$ & $\begin{array}{r}12 \\
4.0 \\
1.0 \\
3.0 \\
--\end{array}$ \\
\hline $\begin{array}{l}427 \\
430 \\
437 \\
444\end{array}$ & $\begin{array}{l}08-22-84 \\
08-20-84 \\
08-22-84 \\
08-20-84\end{array}$ & $\begin{array}{l}\text { Oba } \\
\text { Onl } \\
\text { Oba } \\
\epsilon_{g}\end{array}$ & $\begin{array}{l}11.5 \\
11.5 \\
12.0 \\
11.0\end{array}$ & $\begin{array}{r}330 \\
<100 \\
300 \\
<100\end{array}$ & $\begin{array}{l}<50 \\
<50 \\
120 \\
<50\end{array}$ & $\begin{array}{l}-- \\
64 \\
-- \\
--\end{array}$ & $\begin{array}{l}-- \\
42 \\
-- \\
--\end{array}$ & $\begin{array}{l}--1 \\
--- \\
---\end{array}$ & $\begin{array}{r}-- \\
1.3 \\
-- \\
--\end{array}$ & $\begin{array}{l}204 \\
274 \\
314 \\
220\end{array}$ & $\begin{array}{l}7.0 \\
10 \\
470 \\
4.0\end{array}$ \\
\hline 459 & $08-22-84$ & Oc1 & 12.0 & $<100$ & $<50$ & -- & -- & --- & -- & 238 & 21 \\
\hline $\begin{array}{l}465 \\
479 \\
485 \\
491 \\
608\end{array}$ & $\begin{array}{l}08-22-84 \\
08-21-84 \\
08-22-84 \\
08-22-84 \\
06-13-85\end{array}$ & $\begin{array}{l}C_{g} \\
\text { Ond } \\
\text { Oc } 1 \\
\text { Ond } \\
\text { Oc } 1\end{array}$ & $\begin{array}{l}11.5 \\
11.0 \\
11.0 \\
11.0 \\
12.5\end{array}$ & $\begin{array}{r}220 \\
750 \\
100 \\
<100 \\
350\end{array}$ & $\begin{array}{r}<50 \\
90 \\
<50 \\
<50 \\
660\end{array}$ & $\begin{array}{c}-- \\
-- \\
-- \\
-- \\
120\end{array}$ & $\begin{array}{l}-- \\
-- \\
-- \\
-- \\
16\end{array}$ & $42^{----}$ & $24^{--}$ & $\begin{array}{r}68 \\
170 \\
220 \\
224 \\
376\end{array}$ & $\begin{array}{r}1.0 \\
7.0 \\
10 \\
10 \\
170\end{array}$ \\
\hline $\begin{array}{l}610 \\
615 \\
619 \\
\text { SP12 } \\
\text { SP17 } \\
\text { SP20 }\end{array}$ & $\begin{array}{l}06-11-85 \\
06-13-85 \\
06-11-85 \\
08-01-85 \\
08-01-85 \\
08-06-85\end{array}$ & $\begin{array}{l}\text { Ocl } \\
\text { Onl } \\
\text { Onl } \\
\epsilon_{8} \\
\text { Onl } 1 \\
\text { Obf }\end{array}$ & $\begin{array}{l}11.5 \\
11.0 \\
11.5 \\
11.5 \\
11.0 \\
11.0\end{array}$ & $\begin{array}{l}<10 \\
<10 \\
<10 \\
<10 \\
<10 \\
<10\end{array}$ & $\begin{array}{l}<10 \\
<10 \\
<10 \\
<10 \\
<10 \\
<10\end{array}$ & $\begin{array}{c}140 \\
60 \\
-- \\
23 \\
34 \\
45\end{array}$ & $\begin{array}{l}6.8 \\
34 \\
-- \\
13 \\
17 \\
25\end{array}$ & $\begin{array}{c}3.4 \\
1.0 \\
-- \\
.34 \\
1.3 \\
1.4\end{array}$ & $\begin{array}{r}2.2 \\
1.0 \\
-- \\
<.13 \\
.26 \\
.55\end{array}$ & $\begin{array}{l}306 \\
238 \\
248 \\
122 \\
152 \\
194\end{array}$ & $\begin{array}{l}19 \\
14 \\
66 \\
2.0 \\
5.0 \\
8.0\end{array}$ \\
\hline
\end{tabular}


Table 8.--Chemical analyses of major constituents in well and spring water--Continued

\begin{tabular}{|c|c|c|c|c|c|c|c|c|c|c|c|}
\hline $\begin{array}{l}\text { Sulfate, } \\
\text { dis- } \\
\text { solved } \\
\left(\mathrm{mg}_{\mathrm{S}} \mathrm{L}\right. \\
\text { as } \mathrm{SO}_{4} \text { ) }\end{array}$ & $\begin{array}{l}\text { Fluo- } \\
\text { ride, } \\
\text { dis- } \\
\text { solved } \\
\text { (mg/L } \\
\text { as F) }\end{array}$ & $\begin{array}{l}\text { Nitro- } \\
\text { gen } \\
\text { ammonia, } \\
\text { dis- } \\
\text { solved } \\
\text { (mg/L } \\
\text { as } N \text { ) }\end{array}$ & $\begin{array}{l}\text { Nitro- } \\
\text { gen } \\
\text { nitrite, } \\
\text { dis- } \\
\text { solved } \\
\text { (mg/L } \\
\text { as } N \text { ) }\end{array}$ & $\begin{array}{l}\text { Nitro- } \\
\text { gen } \\
\text { nitrate, } \\
\text { dis- } \\
\text { solved } \\
\text { (mg/L } \\
\text { as } N \text { ) }\end{array}$ & $\begin{array}{l}\text { Phos- } \\
\text { phorus, } \\
\text { ortho, } \\
\text { dis- } \\
\text { solved } \\
\text { (mg/L } \\
\text { as P) }\end{array}$ & $\begin{array}{l}\text { Hard- } \\
\text { ness } \\
\text { (mg/L } \\
\text { as } \\
\mathrm{CaCO}_{3} \text { ) }\end{array}$ & $\begin{array}{l}\text { Solids, } \\
\text { residue } \\
\text { at } 105 \\
\text { dis, } \\
\text { solved } \\
\text { (mg/L) }\end{array}$ & $\begin{array}{l}\text { Spe- } \\
\text { cific } \\
\text { con- } \\
\text { duct- } \\
\text { ance } \\
(\mu \mathrm{S} / \mathrm{cm})\end{array}$ & $\begin{array}{l}\mathrm{pH} \\
\text { (stand- } \\
\text { ard } \\
\text { units) }\end{array}$ & Date & $\begin{array}{l}\text { County } \\
\text { well or } \\
\text { spring } \\
\text { number }\end{array}$ \\
\hline \multicolumn{12}{|c|}{ Bedford County } \\
\hline $\begin{array}{l}30 \\
25 \\
-- \\
30 \\
10\end{array}$ & $\begin{array}{r}<0.1 \\
<.1 \\
<.1 \\
.2 \\
<.1\end{array}$ & $\begin{array}{r}0.01 \\
.01 \\
.01 \\
.01 \\
.01\end{array}$ & $\begin{array}{r}<0.01 \\
<.01 \\
<.01 \\
<.01 \\
<.01\end{array}$ & $\begin{array}{r}10.0 \\
7.90 \\
0.08 \\
1.50 \\
.04\end{array}$ & $\begin{array}{l}-- \\
-- \\
-- \\
--\end{array}$ & $\begin{array}{l}390 \\
260 \\
180 \\
170 \\
240\end{array}$ & $\begin{array}{l}570 \\
450 \\
300 \\
248 \\
254\end{array}$ & $\begin{array}{r}600 \\
615 \\
-2 \\
365 \\
455\end{array}$ & $\begin{array}{r}7.40 \\
-1- \\
6.80 \\
7.30\end{array}$ & $\begin{array}{l}08-20-80 \\
08-20-80 \\
08-21-80 \\
08-27-80 \\
09-18-80\end{array}$ & $\begin{array}{l}310 \\
314 \\
317 \\
389 \\
489\end{array}$ \\
\hline $\begin{array}{l}29 \\
36 \\
48 \\
14 \\
14\end{array}$ & $\begin{array}{l}.14 \\
.14 \\
.18 \\
.1 \\
.1\end{array}$ & $\begin{array}{l}-- \\
-- \\
-- \\
--\end{array}$ & $\begin{array}{l}<.01 \\
<.01 \\
<.01 \\
<.01 \\
<.01\end{array}$ & $\begin{array}{r}7.59 \\
3.27 \\
17.1 \\
3.29 \\
9.00\end{array}$ & $\begin{array}{r}0.003 \\
.002 \\
.002 \\
.004 \\
.002\end{array}$ & $\begin{array}{l}300 \\
360 \\
350 \\
170 \\
240\end{array}$ & $\begin{array}{l}408 \\
558 \\
480 \\
260 \\
310\end{array}$ & $\begin{array}{l}580 \\
830 \\
685 \\
370 \\
510\end{array}$ & $\begin{array}{l}7.50 \\
7.60 \\
6.95 \\
7.80 \\
7.70\end{array}$ & $\begin{array}{l}08-14-84 \\
08-13-84 \\
08-14-84 \\
08-15-84 \\
08-13-84\end{array}$ & $\begin{array}{l}502 \\
508 \\
515 \\
525 \\
530\end{array}$ \\
\hline $\begin{array}{l}12 \\
12 \\
24 \\
16 \\
16\end{array}$ & $\begin{array}{l}.22 \\
.1 \\
.22 \\
.1 \\
.12\end{array}$ & $\begin{array}{l}-- \\
-- \\
-- \\
--\end{array}$ & $\begin{array}{l}<.001 \\
<.01 \\
<.01 \\
<.01 \\
<.01\end{array}$ & $\begin{array}{l}2.05 \\
3.63 \\
1.73 \\
3.77 \\
6.70\end{array}$ & $\begin{array}{l}.002 \\
.003 \\
.002 \\
.002 \\
.003\end{array}$ & $\begin{array}{l}230 \\
290 \\
310 \\
200 \\
240\end{array}$ & $\begin{array}{l}256 \\
344 \\
346 \\
282 \\
334\end{array}$ & $\begin{array}{l}418 \\
490 \\
550 \\
455 \\
445\end{array}$ & $\begin{array}{l}7.65 \\
7.00 \\
7.45 \\
7.80 \\
7.40\end{array}$ & $\begin{array}{l}08-15-84 \\
08-14-84 \\
08-15-84 \\
08-14-84 \\
08-15-84\end{array}$ & $\begin{array}{l}531 \\
539 \\
555 \\
568 \\
574\end{array}$ \\
\hline $\begin{array}{r}16 \\
29 \\
53 \\
27 \\
<10\end{array}$ & $\begin{array}{l}<.1 \\
<.1 \\
<.1 \\
.14 \\
<.1\end{array}$ & $\begin{array}{l}-- \\
-- \\
-- \\
--\end{array}$ & $\begin{array}{l}<.01 \\
<.01 \\
<.01 \\
<.01 \\
<.01\end{array}$ & $\begin{array}{r}5.83 \\
4.18 \\
.12 \\
8.57 \\
3.19\end{array}$ & $\begin{array}{l}.004 \\
.002 \\
.002 \\
.002 \\
.002\end{array}$ & $\begin{array}{l}-- \\
-- \\
-- \\
260 \\
--\end{array}$ & $\begin{array}{l}256 \\
292 \\
508 \\
348 \\
138\end{array}$ & $\begin{array}{l}360 \\
480 \\
825 \\
495 \\
240\end{array}$ & $\begin{array}{l}7.90 \\
7.55 \\
7.25 \\
7.60 \\
8.40\end{array}$ & $\begin{array}{l}08-23-84 \\
08-23-84 \\
08-23-84 \\
08-14-84 \\
08-23-84\end{array}$ & $\begin{array}{l}592 \\
608 \\
621 \\
629 \\
633\end{array}$ \\
\hline $\begin{array}{l}10 \\
30 \\
28\end{array}$ & $\begin{array}{r}1.3 \\
.1 \\
.1\end{array}$ & -- & $\begin{array}{l}<.1 \\
<.001 \\
<.001\end{array}$ & $\begin{array}{l}.034 \\
5.06 \\
3.30\end{array}$ & $\begin{array}{r}.003 \\
<.002 \\
<.002\end{array}$ & $\begin{array}{r}85 \\
190 \\
160\end{array}$ & $\begin{array}{l}240 \\
268 \\
246\end{array}$ & $\begin{array}{l}465 \\
360 \\
315\end{array}$ & $\begin{array}{l}7.90 \\
7.80 \\
7.80\end{array}$ & $\begin{array}{l}08-14-84 \\
07-31-85 \\
08-01-85\end{array}$ & $\begin{array}{l}640 \\
\text { SP26 } \\
\text { SP27 }\end{array}$ \\
\hline \multicolumn{12}{|c|}{ Blair County } \\
\hline $\begin{array}{c}15 \\
30 \\
10 \\
5.0 \\
30\end{array}$ & $\begin{array}{r}<.1 \\
<.1 \\
<.1 \\
.1 \\
.3\end{array}$ & $\begin{array}{l}.01 \\
.02 \\
.01 \\
.01 \\
.01\end{array}$ & $\begin{array}{l}<.01 \\
<.01 \\
.034 \\
<.01 \\
<.01\end{array}$ & $\begin{array}{l}2.60 \\
5.10 \\
6.40 \\
2.60 \\
5.10\end{array}$ & $\begin{array}{l}-- \\
-- \\
-- \\
-- \\
--\end{array}$ & $\begin{array}{l}220 \\
300 \\
190 \\
130 \\
370\end{array}$ & $\begin{array}{r}306 \\
380 \\
280 \\
96 \\
452\end{array}$ & $\begin{array}{l}509 \\
605 \\
450 \\
305 \\
605\end{array}$ & $\begin{array}{l}-- \\
-- \\
-- \\
--\end{array}$ & $\begin{array}{l}06-04-80 \\
06-10-80 \\
06-11-80 \\
06-16-80 \\
07-02-80\end{array}$ & $\begin{array}{l}150 \\
223 \\
248 \\
254 \\
270\end{array}$ \\
\hline $\begin{array}{l}5.0 \\
20 \\
40 \\
20 \\
20\end{array}$ & $\begin{array}{l}<.1 \\
<.1 \\
<.1 \\
<.1 \\
<.1\end{array}$ & $\begin{array}{l}.01 \\
.01 \\
.01 \\
.01 \\
.01\end{array}$ & $\begin{array}{l}<.01 \\
.01 \\
<.01 \\
<.01 \\
<.01\end{array}$ & $\begin{array}{l}5.70 \\
8.80 \\
1.50 \\
2.60 \\
1.50\end{array}$ & $\begin{array}{l}-- \\
-- \\
-- \\
-- \\
--\end{array}$ & $\begin{array}{l}220 \\
200 \\
240 \\
150 \\
210\end{array}$ & $\begin{array}{l}308 \\
264 \\
328 \\
182 \\
254\end{array}$ & $\begin{array}{l}435 \\
427 \\
605 \\
335 \\
467\end{array}$ & $\begin{array}{l}7 .-10 \\
7.30 \\
7.20 \\
7.30\end{array}$ & $\begin{array}{l}07-02-80 \\
07-08-80 \\
07-08-80 \\
07-09-80 \\
07-09-80\end{array}$ & $\begin{array}{l}272 \\
297 \\
298 \\
361 \\
362\end{array}$ \\
\hline $\begin{array}{r}22 \\
40 \\
<10 \\
<10 \\
67\end{array}$ & $\begin{array}{l}<.1 \\
<.1 \\
<.1 \\
<.1 \\
\quad .15\end{array}$ & $\begin{array}{l}-- \\
-- \\
-- \\
-- \\
--\end{array}$ & $\begin{array}{l}<.01 \\
<.01 \\
<.01 \\
<.01 \\
<.01\end{array}$ & $\begin{array}{r}11.7 \\
4.95 \\
.69 \\
2.20 \\
8.80\end{array}$ & $\begin{array}{l}.002 \\
.002 \\
.002 \\
.004 \\
.002\end{array}$ & $\begin{array}{r}320 \\
370 \\
64 \\
-- \\
150\end{array}$ & $\begin{array}{r}390 \\
422 \\
96 \\
176 \\
518\end{array}$ & $\begin{array}{l}600 \\
620 \\
125 \\
270 \\
845\end{array}$ & $\begin{array}{l}7.70 \\
7.20 \\
8.60 \\
8.20 \\
7.23\end{array}$ & $\begin{array}{l}08-21-84 \\
07-21-84 \\
08-21-84 \\
08-21-84 \\
08-20-84\end{array}$ & $\begin{array}{l}390 \\
394 \\
402 \\
407 \\
423\end{array}$ \\
\hline $\begin{array}{l}22 \\
16 \\
71 \\
10 \\
63\end{array}$ & $\begin{array}{l}<.1 \\
<.1 \\
<.1 \\
<.1 \\
<.1\end{array}$ & $\begin{array}{l}-- \\
-- \\
-- \\
-- \\
--\end{array}$ & $\begin{array}{l}<.01 \\
<.01 \\
<.01 \\
<.01 \\
<.01\end{array}$ & $\begin{array}{r}7.15 \\
6.71 \\
100 \\
4.18 \\
7.59\end{array}$ & $\begin{array}{l}.003 \\
.002 \\
.004 \\
.002 \\
.002\end{array}$ & $\begin{array}{r}-- \\
330 \\
760 \\
-- \\
--\end{array}$ & $\begin{array}{r}324 \\
426 \\
2,390 \\
368 \\
464\end{array}$ & $\begin{array}{r}490 \\
700 \\
>1,000 \\
500 \\
720\end{array}$ & $\begin{array}{l}8.00 \\
7.60 \\
6.40 \\
7.80 \\
7.40\end{array}$ & $\begin{array}{l}08-22-84 \\
08-20-84 \\
08-22-84 \\
08-20-84 \\
08-22-84\end{array}$ & $\begin{array}{l}427 \\
430 \\
437 \\
444 \\
459\end{array}$ \\
\hline $\begin{array}{r}<10 \\
12 \\
22 \\
20 \\
60\end{array}$ & $\begin{array}{l}<.1 \\
<.1 \\
<.1 \\
<.1 \\
.12\end{array}$ & $\begin{array}{l}-- \\
-- \\
-- \\
--\end{array}$ & $\begin{array}{l}<.01 \\
<.01 \\
<.01 \\
-- \\
<.001\end{array}$ & $\begin{array}{c}.88 \\
7.37 \\
7.81 \\
11.0 \\
3.74\end{array}$ & $\begin{array}{l}.002 \\
.003 \\
.003 \\
.002 \\
.006\end{array}$ & $\begin{array}{l}-- \\
-- \\
-- \\
-- \\
370\end{array}$ & $\begin{array}{l}106 \\
272 \\
352 \\
358 \\
758\end{array}$ & $\begin{array}{r}145 \\
410 \\
560 \\
550 \\
>1,000\end{array}$ & $\begin{array}{l}8.40 \\
7.62 \\
7.55 \\
7.90 \\
7.30\end{array}$ & $\begin{array}{l}08-22-84 \\
08-21-84 \\
08-22-84 \\
08-22-84 \\
06-13-85\end{array}$ & $\begin{array}{l}465 \\
479 \\
485 \\
491 \\
608\end{array}$ \\
\hline $\begin{array}{r}26 \\
25 \\
24 \\
28 \\
28 \\
<10\end{array}$ & $\begin{array}{l}<.1 \\
<.1 \\
<.1 \\
<.1 \\
<.1 \\
<.1\end{array}$ & $\begin{array}{l}-- \\
-- \\
-- \\
-- \\
--\end{array}$ & $\begin{array}{l}.004 \\
<.001 \\
<.001 \\
<1.00 \\
<.001 \\
<.001\end{array}$ & $\begin{array}{r}12.3 \\
14.3 \\
17.6 \\
.82 \\
3.08 \\
7.70\end{array}$ & $\begin{array}{r}.003 \\
.003 \\
.004 \\
<.002 \\
<.002 \\
.002\end{array}$ & $\begin{array}{r}370 \\
290 \\
-- \\
110 \\
160 \\
220\end{array}$ & $\begin{array}{l}488 \\
398 \\
480 \\
196 \\
226 \\
342\end{array}$ & $\begin{array}{l}760 \\
625 \\
790 \\
265 \\
350 \\
435\end{array}$ & $\begin{array}{l}7 .- \\
7.40 \\
7.40 \\
8.10 \\
7.60 \\
7.60\end{array}$ & $\begin{array}{l}06-11-85 \\
06-13-85 \\
06-11-85 \\
08-01-85 \\
08-01-85 \\
08-06-85\end{array}$ & $\begin{array}{l}610 \\
615 \\
619 \\
\text { SP12 } \\
\text { SP17 } \\
\text { SP20 }\end{array}$ \\
\hline
\end{tabular}


Table 8.--Chemical analyses of major constituents in well and spring water--Continued

\begin{tabular}{|c|c|c|c|c|c|c|c|c|c|c|c|}
\hline $\begin{array}{l}\text { County } \\
\text { well or } \\
\text { spring } \\
\text { number }\end{array}$ & Date & $\begin{array}{l}\text { Geo- } \\
\text { logig } \\
\text { unit }\end{array}$ & $\begin{array}{c}\text { Temper- } \\
\text { ature } \\
\left({ }^{\circ} \mathrm{C}\right)\end{array}$ & $\begin{array}{l}\text { Iron, } \\
\text { dis- } \\
\text { solved } \\
(\mu g / L \\
\text { as } F \theta)\end{array}$ & $\begin{array}{l}\text { Manga- } \\
\text { nese, } \\
\text { dis- } \\
\text { solved } \\
(\mu \mathrm{g} / \mathrm{L} \\
\text { as } \mathrm{Mn} \text { ) }\end{array}$ & $\begin{array}{l}\text { Calcium, } \\
\text { dis- } \\
\text { solved } \\
\text { (mg/L } \\
\text { as Ca) }\end{array}$ & $\begin{array}{l}\text { Magne- } \\
\text { sium, } \\
\text { dis- } \\
\text { solved } \\
\text { (mg/L } \\
\text { as Mg) }\end{array}$ & $\begin{array}{l}\text { Sodium, } \\
\text { dis- } \\
\text { solved } \\
\text { (mg/L } \\
\text { as } \mathrm{Na} \text { ) }\end{array}$ & $\begin{array}{l}\text { Potas- } \\
\text { sium, } \\
\text { dis- } \\
\text { solved } \\
\text { (mg/L } \\
\text { as K) }\end{array}$ & $\begin{array}{l}\text { Alka- } \\
\text { linity, } \\
\text { lab } \\
\text { (mg/L } \\
\text { as } \mathrm{CaCO}_{3} \text { ) }\end{array}$ & $\begin{array}{l}\text { Chlo- } \\
\text { ride, } \\
\text { dis- } \\
\text { solved } \\
\text { (mg/L } \\
\text { as Cl) }\end{array}$ \\
\hline
\end{tabular}

\begin{tabular}{|c|c|c|c|c|c|c|c|c|c|c|c|}
\hline \multirow[b]{2}{*}{$\begin{array}{l}238 \\
240 \\
247 \\
258 \\
291\end{array}$} & \multicolumn{11}{|c|}{ Centre County } \\
\hline & $\begin{array}{l}07-16-80 \\
07-16-80 \\
08-06-80 \\
10-08-80 \\
10-22-80\end{array}$ & $\begin{array}{l}\text { Os } \\
\text { Os } \\
\text { Obl } \\
\text { On } \\
\text { Obf }\end{array}$ & $\begin{array}{r}1.0 \\
1.5 \\
-- \\
9.5 \\
--\end{array}$ & $\begin{array}{r}10 \\
220 \\
-- \\
30 \\
10\end{array}$ & $\begin{array}{l}-- \\
<-10 \\
10 \\
<10\end{array}$ & $\begin{array}{l}33 \\
52 \\
89 \\
52 \\
33\end{array}$ & $\begin{array}{l}9.6 \\
20 \\
7.8 \\
32 \\
23\end{array}$ & $\begin{array}{l}0.7 \\
1.0 \\
1.8 \\
1.1 \\
2.5\end{array}$ & $\begin{array}{l}-- \\
-\overline{6} \\
0.6 \\
.9 \\
1.0\end{array}$ & $\begin{array}{l}120 \\
200 \\
230 \\
250 \\
170\end{array}$ & $\begin{array}{r}3.0 \\
8.0 \\
4.0 \\
4.0 \\
10\end{array}$ \\
\hline $\begin{array}{l}296 \\
299 \\
358 \\
372\end{array}$ & $\begin{array}{l}10-21-80 \\
06-18-85 \\
10-23-80 \\
11-05-80 \\
06-26-85\end{array}$ & $\begin{array}{l}\text { Obf } \\
\text { Oa } \\
\text { Obf } \\
\text { Ocn } \\
\text { Ocn }\end{array}$ & $\begin{array}{r}1.0 \\
11.0 \\
11.0 \\
11.0\end{array}$ & $\begin{array}{r}60 \\
48 \\
10 \\
70 \\
<10\end{array}$ & $\begin{array}{r}10 \\
<10 \\
10 \\
10 \\
<10\end{array}$ & $\begin{array}{r}64 \\
67 \\
63 \\
99 \\
110\end{array}$ & $\begin{array}{l}39 \\
29 \\
29 \\
4.0 \\
3.9\end{array}$ & $\begin{array}{l}5.1 \\
4.5 \\
3.1 \\
4.6 \\
3.0\end{array}$ & $\begin{array}{l}1.3 \\
1.5 \\
1.0 \\
3.0 \\
1.7\end{array}$ & $\begin{array}{l}260 \\
250 \\
250 \\
240 \\
236\end{array}$ & $\begin{array}{l}16 \\
21 \\
11 \\
21 \\
10\end{array}$ \\
\hline $\begin{array}{l}399 \\
402 \\
403 \\
404 \\
410\end{array}$ & $\begin{array}{l}06-27-85 \\
06-10-85 \\
06-10-85 \\
06-12-85 \\
06-12-85\end{array}$ & $\begin{array}{l}\text { Ocn } \\
C_{g m} \\
O s \\
C_{g 1} \\
C_{g 1}\end{array}$ & $\begin{array}{r}11.0 \\
10.5 \\
1.0 \\
10.5 \\
1.0\end{array}$ & $\begin{array}{r}<10 \\
93 \\
240 \\
<10 \\
30\end{array}$ & $\begin{array}{l}<10 \\
<10 \\
<10 \\
<10 \\
<10\end{array}$ & $\begin{array}{r}140 \\
61 \\
39 \\
25 \\
69\end{array}$ & $\begin{array}{l}14 \\
19 \\
9.1 \\
11 \\
24\end{array}$ & $\begin{array}{r}3.4 \\
15^{3.4} .3 \\
13^{.5}\end{array}$ & $\begin{array}{l}.4 \\
.9 \\
.7 \\
.4 \\
.9\end{array}$ & $\begin{array}{l}328 \\
194 \\
126 \\
106 \\
146\end{array}$ & $\begin{array}{r}12 \\
66 \\
5.0 \\
2.0 \\
4.0\end{array}$ \\
\hline $\begin{array}{l}411 \\
414 \\
418 \\
421 \\
426\end{array}$ & $\begin{array}{l}06-12-85 \\
06-20-85 \\
06-20-85 \\
06-19-85 \\
06-19-85\end{array}$ & $\begin{array}{l}\mathrm{Cgl} \\
\mathrm{Oa} \\
\mathrm{Obf} \\
\mathrm{Ob}_{\mathbf{s}} \\
\mathrm{Obf}\end{array}$ & $\begin{array}{r}1.0 \\
11.0 \\
11.0 \\
11.0 \\
11.0\end{array}$ & $\begin{array}{r}26 \\
<10 \\
51 \\
150 \\
140\end{array}$ & $\begin{array}{l}<10 \\
<10 \\
<10 \\
<10 \\
<10\end{array}$ & $\begin{array}{l}32 \\
67 \\
60 \\
67 \\
65\end{array}$ & $\begin{array}{l}12 \\
23 \\
29 \\
13 \\
29\end{array}$ & $\begin{array}{l}7.4 \\
5.9 \\
1.7 \\
1.5 \\
7.0\end{array}$ & $\begin{array}{r}.9 \\
.3 \\
<.1 \\
.3 \\
.2\end{array}$ & $\begin{array}{l}226 \\
240 \\
260 \\
202 \\
160\end{array}$ & $\begin{array}{c}27 \\
17 \\
5.0 \\
6.0 \\
66\end{array}$ \\
\hline $\begin{array}{l}438 \\
447 \\
485 \\
487 \\
494\end{array}$ & $\begin{array}{l}06-12-85 \\
06-20-85 \\
06-27-85 \\
06-25-85 \\
06-27-85\end{array}$ & $\begin{array}{l}\text { On } \\
\text { Obf } \\
\text { Obl } \\
\text { Obl } \\
\text { Obf }\end{array}$ & $\begin{array}{l}11.0 \\
11.0 \\
11.0 \\
10.5 \\
10.5\end{array}$ & $\begin{array}{r}<10 \\
1,100 \\
<10 \\
<10 \\
<10\end{array}$ & $\begin{array}{l}<10 \\
<10 \\
<10 \\
<10 \\
<10\end{array}$ & $\begin{array}{r}65 \\
46 \\
64 \\
120 \\
70\end{array}$ & $\begin{array}{l}35 \\
5.3 \\
21 \\
25 \\
36\end{array}$ & $\begin{array}{l}13 \\
1.6 \\
5.1 \\
7.8 \\
12\end{array}$ & $\begin{array}{r}1.2 \\
<.1 \\
.6 \\
1.1 \\
.6\end{array}$ & $\begin{array}{l}246 \\
132 \\
232 \\
308 \\
288\end{array}$ & $\begin{array}{l}42 \\
2.0 \\
18 \\
23 \\
30\end{array}$ \\
\hline $\begin{array}{l}498 \\
509 \\
512 \\
518 \\
536\end{array}$ & $\begin{array}{l}06-27-85 \\
06-25-85 \\
06-26-85 \\
06-26-85 \\
06-17-85\end{array}$ & $\begin{array}{l}\text { Ocn } \\
\text { Ob1 } \\
\text { Ob1 } \\
\text { Ocn } \\
\text { Obf }\end{array}$ & $\begin{array}{l}12.0 \\
10.5 \\
10.5 \\
11.0 \\
11.0\end{array}$ & $\begin{array}{r}43 \\
<10 \\
450 \\
23 \\
<10\end{array}$ & $\begin{array}{l}<10 \\
<10 \\
<10 \\
<10 \\
<10\end{array}$ & $\begin{array}{r}110 \\
62 \\
79 \\
66 \\
67\end{array}$ & $\begin{array}{l}7.3 \\
25 \\
4.3 \\
30 \\
29\end{array}$ & $\begin{array}{r}3.0 \\
1.0 \\
9.2 \\
23.8 \\
.8\end{array}$ & $\begin{array}{r}.5 \\
.4 \\
.5 \\
2.0 \\
.8\end{array}$ & $\begin{array}{l}282 \\
242 \\
196 \\
320 \\
290\end{array}$ & $\begin{array}{l}9.0 \\
7.0 \\
43 \\
19 \\
14\end{array}$ \\
\hline $\begin{array}{l}544 \\
546 \\
555 \\
589 \\
603\end{array}$ & $\begin{array}{l}06-17-85 \\
07-11-85 \\
06-24-85 \\
06-18-85 \\
06-26-85\end{array}$ & $\begin{array}{l}\text { On } \\
O b a \\
O n \\
O b f \\
O b l\end{array}$ & $\begin{array}{l}11.0 \\
11.0 \\
12.0 \\
11.5 \\
10.5\end{array}$ & $\begin{array}{r}<10 \\
<10 \\
22 \\
<10 \\
<10\end{array}$ & $\begin{array}{l}<10 \\
<10 \\
<10 \\
<10 \\
<10\end{array}$ & $\begin{array}{r}67 \\
67 \\
49 \\
65 \\
140\end{array}$ & $\begin{array}{l}29 \\
29 \\
20 \\
28 \\
5.2\end{array}$ & $\begin{array}{r}2.6 \\
2.0 \\
10 \\
4.7 \\
6.2\end{array}$ & $\begin{array}{r}8.7 \\
.3 \\
1.3 \\
2.5 \\
.8\end{array}$ & $\begin{array}{l}314 \\
292 \\
192 \\
228 \\
342\end{array}$ & $\begin{array}{l}18 \\
8.0 \\
23 \\
17 \\
14\end{array}$ \\
\hline $\begin{array}{l}609 \\
623 \\
632 \\
640 \\
\text { SP4 } \\
\text { SP11 } \\
\text { SP14 } \\
\text { SP17 } \\
\text { SP18 } \\
\text { SP19 }\end{array}$ & $\begin{array}{l}06-18-85 \\
06-26-85 \\
06-25-85 \\
06-18-85 \\
08-08-85 \\
08-13-85 \\
08-07-85 \\
08-08-85 \\
08-15-85 \\
08-08-85\end{array}$ & $\begin{array}{l}C_{g} \\
O c n \\
C_{g} \\
O b f \\
O b l \\
O b l \\
O b f \\
O b f \\
\text { On } \\
C_{g m} \\
\text { On }\end{array}$ & $\begin{array}{r}11.5 \\
1.0 \\
10.5 \\
11.0 \\
17.0 \\
11.0 \\
12.0 \\
12.0 \\
12.0 \\
12.0\end{array}$ & $\begin{array}{r}<10 \\
<10 \\
170 \\
370 \\
190 \\
27 \\
<10 \\
<10 \\
<10 \\
<10\end{array}$ & $\begin{array}{l}<10 \\
<10 \\
<10 \\
<10 \\
15 \\
<10 \\
<10 \\
<10 \\
<10 \\
<10\end{array}$ & $\begin{array}{l}67 \\
20 \\
37 \\
67 \\
40 \\
65 \\
41 \\
67 \\
40 \\
29\end{array}$ & $\begin{array}{l}29 \\
1.9 \\
22 \\
29 \\
7.9 \\
12 \\
6.3 \\
31 \\
17 \\
14\end{array}$ & $\begin{array}{l}12 \\
.7 \\
1.2 \\
1.4 \\
3.6 \\
4.4 \\
2.0 \\
4.3 \\
3.8 \\
3.3\end{array}$ & $\begin{array}{r}1.3 \\
.5 \\
.7 \\
.7 \\
1.9 \\
.72 \\
.53 \\
.63 \\
.63 \\
.4\end{array}$ & $\begin{array}{r}250 \\
58 \\
172 \\
288 \\
118 \\
172 \\
110 \\
242 \\
156 \\
132\end{array}$ & $\begin{array}{c}34 \\
2.0 \\
4.0 \\
10 \\
10 \\
13 \\
6.0 \\
16 . \\
14 \\
10\end{array}$ \\
\hline \multirow[t]{2}{*}{$\begin{array}{l}\text { SP23 } \\
\text { SP24 } \\
\text { SP25 } \\
\text { SP32 }\end{array}$} & $\begin{array}{l}08-14-85 \\
08-15-85 \\
08-14-85 \\
08-07-85\end{array}$ & $\begin{array}{l}\text { Obl } \\
\text { Obl } \\
\text { Ocn } \\
\text { Ocn }\end{array}$ & $\begin{array}{r}1.5 \\
11.5 \\
11.0 \\
12.0\end{array}$ & $\begin{array}{l}<10 \\
<10 \\
<10 \\
<10\end{array}$ & $\begin{array}{l}<10 \\
<10 \\
<10 \\
<10\end{array}$ & $\begin{array}{l}88 \\
74 \\
50 \\
57\end{array}$ & $\begin{array}{c}9.8 \\
18 \\
6.2 \\
19\end{array}$ & $\begin{array}{l}3.0 \\
2.1 \\
1.5 \\
1.5\end{array}$ & $\begin{array}{l}.78 \\
.43 \\
.7 \\
.33\end{array}$ & $\begin{array}{l}232 \\
192 \\
150 \\
198\end{array}$ & $\begin{array}{r}11 \\
7.0 \\
5.0 \\
8.0\end{array}$ \\
\hline & \multicolumn{11}{|c|}{ Clinton County } \\
\hline $\begin{array}{l}156 \\
157 \\
159 \\
162 \\
167\end{array}$ & $\begin{array}{l}06-09-81 \\
06-08-81 \\
06-08-81 \\
06-09-81 \\
06-07-81\end{array}$ & $\begin{array}{l}\text { Obf } \\
\text { Obl } \\
\text { Obl } \\
\text { Obf } \\
\text { Obf }\end{array}$ & $\begin{array}{l}-- \\
-- \\
-- \\
--\end{array}$ & $\begin{array}{l}1 \\
<1 \\
<1 \\
<1 \\
<1\end{array}$ & $\begin{array}{l}<1 \\
<1 \\
<1 \\
<1 \\
<1\end{array}$ & $\begin{array}{l}36 \\
52 \\
45 \\
80 \\
58\end{array}$ & $\begin{array}{c}15 \\
2.3 \\
4.7 \\
41 \\
34\end{array}$ & $\begin{array}{l}5.1 \\
6.3 \\
6.5 \\
20 \\
14\end{array}$ & $\begin{array}{l}.64 \\
.5 \\
.4 \\
1.8 \\
1.2\end{array}$ & $\begin{array}{l}128 \\
124 \\
110 \\
288 \\
246\end{array}$ & $\begin{array}{l}8.0 \\
5.0 \\
9.0 \\
26 \\
37\end{array}$ \\
\hline $\begin{array}{l}169 \\
172 \\
277 \\
283 \\
284\end{array}$ & $\begin{array}{l}06-09-81 \\
06-10-81 \\
06-16-81 \\
06-17-81 \\
06-17-81\end{array}$ & $\begin{array}{l}\text { Obf } \\
\text { Ocn } \\
\text { Ob1 } \\
\text { Ocn } \\
\text { Ocn }\end{array}$ & $\begin{array}{l}-- \\
=- \\
-- \\
--\end{array}$ & $\begin{array}{l}<1 \\
<1 \\
<1 \\
<1 \\
<1\end{array}$ & $\begin{array}{l}<1 \\
<1 \\
<1 \\
<1 \\
<1\end{array}$ & $\begin{array}{r}54 \\
110 \\
35 \\
52 \\
100\end{array}$ & $\begin{array}{l}29 \\
17 \\
13 \\
2.5 \\
4.1\end{array}$ & $\begin{array}{r}5.5 \\
8.2 \\
3.6 \\
1.7 \\
10\end{array}$ & $\begin{array}{l}.64 \\
.58 \\
1.0 \\
1.4 \\
.92\end{array}$ & $\begin{array}{l}230 \\
308 \\
130 \\
130 \\
230\end{array}$ & $\begin{array}{c}6.0 \\
6.0 \\
14 \\
4.0 \\
31\end{array}$ \\
\hline
\end{tabular}


Table 8.--Chemical analyses of major constituents in well and spring water--Continued

\begin{tabular}{|c|c|c|c|c|c|c|c|c|c|c|c|}
\hline $\begin{array}{l}\text { Sulfate, } \\
\text { dis- } \\
\text { solved } \\
\text { (ms/L } \\
\text { as } \mathrm{SO}_{4} \text { ) }\end{array}$ & $\begin{array}{l}\text { Fluo- } \\
\text { ride, } \\
\text { dis- } \\
\text { solved } \\
\text { (ms/L } \\
\text { as F) }\end{array}$ & $\begin{array}{l}\text { Nitro- } \\
\text { gen } \\
\text { ammonia, } \\
\text { dis- } \\
\text { solved } \\
\text { (mg/L } \\
\text { as N) }\end{array}$ & $\begin{array}{l}\text { Nitro- } \\
\text { gen } \\
\text { nitrite, } \\
\text { dis- } \\
\text { solved } \\
\text { (mg/L } \\
\text { as } N \text { ) }\end{array}$ & $\begin{array}{l}\text { Nitro- } \\
\text { gen } \\
\text { nitrate, } \\
\text { dis- } \\
\text { solved } \\
\text { (ms/L } \\
\text { as } N \text { ) }\end{array}$ & $\begin{array}{l}\text { Phos- } \\
\text { phorus, } \\
\text { ortho, } \\
\text { dis- } \\
\text { solved } \\
\text { (mg/L } \\
\text { as P) }\end{array}$ & $\begin{array}{l}\text { Bard- } \\
\text { ness } \\
(m g / L \\
\text { as } \\
\left(\mathrm{aCO}_{3}\right)\end{array}$ & $\begin{array}{l}\text { Solids, } \\
\text { residue } \\
\text { at } 105 \\
{ }^{\circ} \mathrm{C}, \\
\text { dis- } \\
\text { solved } \\
\text { (mg/L) }\end{array}$ & $\begin{array}{l}\text { Spe- } \\
\text { cific } \\
\text { con- } \\
\text { duct- } \\
\text { ance } \\
(\mu S / c m)\end{array}$ & $\begin{array}{l}\mathrm{pH} \\
\text { (stand- } \\
\text { ard } \\
\text { units) }\end{array}$ & Date & $\begin{array}{l}\text { County } \\
\text { well or } \\
\text { spring } \\
\text { number }\end{array}$ \\
\hline
\end{tabular}

\begin{tabular}{|c|c|c|c|c|c|c|c|c|c|c|c|}
\hline \multicolumn{12}{|c|}{ Centre County } \\
\hline $\begin{array}{l}10 \\
20 \\
25 \\
10 \\
10\end{array}$ & $\begin{array}{r}<0.1 \\
<.1 \\
.1 \\
<.1 \\
.2\end{array}$ & $\begin{array}{l}0.02 \\
.01 \\
.01 \\
.01 \\
.01\end{array}$ & $\begin{array}{l}<0.01 \\
<.01 \\
<.01 \\
<.01 \\
<.01\end{array}$ & $\begin{array}{l}4.00 \\
5.10 \\
2.80 \\
1.90 \\
2.00\end{array}$ & $\begin{array}{l}-- \\
-- \\
-- \\
-- \\
--\end{array}$ & $\begin{array}{l}120 \\
210 \\
250 \\
260 \\
180\end{array}$ & $\begin{array}{l}226 \\
342 \\
314 \\
232 \\
248\end{array}$ & $\begin{array}{l}290 \\
420 \\
390 \\
310 \\
430\end{array}$ & $\begin{array}{l}7.70 \\
7.80 \\
7.50 \\
7.40 \\
7.40\end{array}$ & $\begin{array}{l}07-16-80 \\
07-16-80 \\
08-06-80 \\
10-08-80 \\
10-22-80\end{array}$ & $\begin{array}{l}238 \\
240 \\
247 \\
258 \\
291\end{array}$ \\
\hline $\begin{array}{l}15 \\
32 \\
15 \\
20 \\
36\end{array}$ & $\begin{array}{l}.3 \\
.2 \\
.1 \\
.2 \\
.1\end{array}$ & $\begin{array}{c}.01 \\
-- \\
.01 \\
.04 \\
--\end{array}$ & $\begin{array}{l}<.01 \\
<.001 \\
<.01 \\
<.01 \\
<.001\end{array}$ & $\begin{array}{l}5.90 \\
6.60 \\
3.10 \\
8.40 \\
7.30\end{array}$ & $\begin{array}{r}-- \\
0.003 \\
-- \\
-- \\
.025\end{array}$ & $\begin{array}{l}320 \\
290 \\
280 \\
260 \\
300\end{array}$ & $\begin{array}{l}374 \\
440 \\
302 \\
400 \\
376\end{array}$ & $\begin{array}{l}650 \\
610 \\
590 \\
565 \\
580\end{array}$ & $\begin{array}{l}7.70 \\
7.50 \\
7.70 \\
7.70 \\
7.10\end{array}$ & $\begin{array}{l}10-21-80 \\
06-18-85 \\
10-23-80 \\
11-05-80 \\
06-26-85\end{array}$ & $\begin{array}{l}296 \\
299 \\
358 \\
372\end{array}$ \\
\hline $\begin{array}{r}68 \\
<10 \\
<10 \\
<10 \\
<10\end{array}$ & $\begin{array}{l}<.1 \\
<.1 \\
.1 \\
<.1 \\
.1\end{array}$ & $\begin{array}{l}-- \\
-- \\
-- \\
-- \\
--\end{array}$ & $\begin{array}{l}<.001 \\
<.001 \\
<.001 \\
<.001 \\
<.001\end{array}$ & $\begin{array}{c}6.80 \\
10.3 \\
8.40 \\
2.90 \\
1.40\end{array}$ & $\begin{array}{l}.007 \\
.003 \\
.003 \\
.002 \\
.002\end{array}$ & $\begin{array}{l}400 \\
230 \\
140 \\
110 \\
270\end{array}$ & $\begin{array}{l}484 \\
406 \\
196 \\
148 \\
184\end{array}$ & $\begin{array}{l}780 \\
640 \\
320 \\
250 \\
308\end{array}$ & $\begin{array}{l}7.10 \\
7.40 \\
8.50 \\
8.20 \\
7.90\end{array}$ & $\begin{array}{l}06-27-85 \\
06-10-85 \\
06-10-85 \\
06-12-85 \\
06-12-85\end{array}$ & $\begin{array}{l}399 \\
402 \\
403 \\
404 \\
410\end{array}$ \\
\hline $\begin{array}{l}17 \\
31 \\
27 \\
28 \\
59\end{array}$ & $\begin{array}{r}<.1 \\
.1 \\
.2 \\
<.1 \\
.1\end{array}$ & $\begin{array}{l}-- \\
-- \\
-- \\
-- \\
--\end{array}$ & $\begin{array}{l}<.001 \\
<.001 \\
<.001 \\
<.001 \\
<.001\end{array}$ & $\begin{array}{l}5.50 \\
3.50 \\
1.30 \\
3.50 \\
1.50\end{array}$ & $\begin{array}{r}.002 \\
.002 \\
.002 \\
<.002 \\
<.002\end{array}$ & $\begin{array}{l}130 \\
260 \\
270 \\
220 \\
280\end{array}$ & $\begin{array}{l}348 \\
380 \\
410 \\
310 \\
516\end{array}$ & $\begin{array}{l}565 \\
575 \\
515 \\
455 \\
620\end{array}$ & $\begin{array}{l}7.50 \\
7.50 \\
7.40 \\
7.50 \\
7.70\end{array}$ & $\begin{array}{l}06-12-85 \\
06-20-85 \\
06-20-85 \\
06-19-85 \\
06-19-85\end{array}$ & $\begin{array}{l}411 \\
414 \\
418 \\
421 \\
426\end{array}$ \\
\hline $\begin{array}{l}37 \\
22 \\
35 \\
31 \\
38\end{array}$ & $\begin{array}{r}.1 \\
.1 \\
.1 \\
<.1 \\
.1\end{array}$ & $\begin{array}{l}-- \\
-- \\
-- \\
-- \\
--\end{array}$ & $\begin{array}{l}<.001 \\
<.001 \\
<.001 \\
<.001 \\
<.001\end{array}$ & $\begin{array}{l}5.06 \\
1.10 \\
5.50 \\
5.70 \\
3.70\end{array}$ & $\begin{array}{l}.003 \\
.002 \\
.006 \\
.006 \\
.005\end{array}$ & $\begin{array}{l}300 \\
140 \\
250 \\
400 \\
330\end{array}$ & $\begin{array}{l}434 \\
200 \\
428 \\
444 \\
440\end{array}$ & $\begin{array}{l}670 \\
285 \\
560 \\
725 \\
690\end{array}$ & $\begin{array}{l}7.50 \\
7.70 \\
7.40 \\
7.10 \\
7.30\end{array}$ & $\begin{array}{l}06-12-85 \\
06-20-85 \\
06-27-85 \\
06-25-85 \\
06-27-85\end{array}$ & $\begin{array}{l}438 \\
447 \\
485 \\
487 \\
494\end{array}$ \\
\hline $\begin{array}{l}58 \\
35 \\
28 \\
37 \\
98\end{array}$ & $\begin{array}{r}.1 \\
.2 \\
<.1 \\
.4 \\
.2\end{array}$ & $\begin{array}{l}-- \\
-- \\
-- \\
-- \\
--\end{array}$ & $\begin{array}{l}<.001 \\
<.001 \\
<.001 \\
<.001 \\
<.001\end{array}$ & $\begin{array}{r}2.30 \\
4.80 \\
1.40 \\
<0.04 \\
.70\end{array}$ & $\begin{array}{l}.007 \\
.006 \\
.007 \\
.01 \\
.003\end{array}$ & $\begin{array}{l}300 \\
260 \\
210 \\
290 \\
290\end{array}$ & $\begin{array}{l}420 \\
334 \\
376 \\
408 \\
536\end{array}$ & $\begin{array}{l}625 \\
515 \\
480 \\
660 \\
665\end{array}$ & $\begin{array}{l}7.10 \\
7.50 \\
7.30 \\
7.30 \\
7.40\end{array}$ & $\begin{array}{l}06-27-85 \\
06-25-85 \\
06-26-85 \\
06-26-85 \\
06-17-85\end{array}$ & $\begin{array}{l}498 \\
509 \\
512 \\
518 \\
536\end{array}$ \\
\hline $\begin{array}{l}26 \\
30 \\
35 \\
33 \\
32\end{array}$ & $\begin{array}{l}<.1 \\
<.1 \\
<.1 \\
.2 \\
<.1\end{array}$ & $\begin{array}{l}-- \\
-- \\
-- \\
-- \\
--\end{array}$ & $\begin{array}{l}<.001 \\
<.001 \\
<.001 \\
<.001 \\
<.001\end{array}$ & $\begin{array}{r}12.7 \\
7.50 \\
5.70 \\
4.40 \\
9.90\end{array}$ & $\begin{array}{r}.003 \\
.007 \\
.008 \\
<.002 \\
.036\end{array}$ & $\begin{array}{l}290 \\
290 \\
200 \\
280 \\
380\end{array}$ & $\begin{array}{l}524 \\
450 \\
328 \\
382 \\
468\end{array}$ & $\begin{array}{l}750 \\
540 \\
515 \\
540 \\
750\end{array}$ & $\begin{array}{l}7.20 \\
7.20 \\
7.50 \\
7.70 \\
6.80\end{array}$ & $\begin{array}{l}06-17-85 \\
07-11-85 \\
06-24-85 \\
06-18-85 \\
06-26-85\end{array}$ & $\begin{array}{l}544 \\
546 \\
555 \\
589 \\
603\end{array}$ \\
\hline $\begin{array}{r}38 \\
18 \\
16 \\
50 \\
<10\end{array}$ & $\begin{array}{l}.2 \\
<.1 \\
<.1 \\
.2 \\
<.1\end{array}$ & $\begin{array}{l}-- \\
-- \\
-- \\
-- \\
--\end{array}$ & $\begin{array}{l}<.001 \\
<.001 \\
<.001 \\
<.001 \\
<.001\end{array}$ & $\begin{array}{r}7.00 \\
.40 \\
1.90 \\
7.90 \\
1.76\end{array}$ & $\begin{array}{r}.002 \\
.007 \\
.005 \\
<.002 \\
.019\end{array}$ & $\begin{array}{r}290 \\
57 \\
180 \\
290 \\
130\end{array}$ & $\begin{array}{r}482 \\
82 \\
230 \\
550 \\
256\end{array}$ & $\begin{array}{l}670 \\
123 \\
360 \\
660 \\
305\end{array}$ & $\begin{array}{l}7.40 \\
8.00 \\
7.50 \\
7.50 \\
7.60\end{array}$ & $\begin{array}{l}06-18-85 \\
06-26-85 \\
06-25-85 \\
06-18-85 \\
08-08-85\end{array}$ & $\begin{array}{l}609 \\
623 \\
632 \\
640 \\
S P 4\end{array}$ \\
\hline $\begin{array}{r}26 \\
<10 \\
28 \\
<10 \\
<10\end{array}$ & $\begin{array}{l}<.1 \\
<.1 \\
<.1 \\
<.1 \\
<.1\end{array}$ & $\begin{array}{l}-- \\
-- \\
-- \\
-- \\
--\end{array}$ & $\begin{array}{l}<.001 \\
<.001 \\
<.001 \\
<.001 \\
<.001\end{array}$ & $\begin{array}{l}5.46 \\
3.74 \\
7.92 \\
4.20 \\
1.88\end{array}$ & $\begin{array}{l}.002 \\
.003 \\
.002 \\
.004 \\
.002\end{array}$ & $\begin{array}{l}210 \\
130 \\
290 \\
170 \\
130\end{array}$ & $\begin{array}{l}274 \\
218 \\
252 \\
218 \\
452\end{array}$ & $\begin{array}{l}450 \\
290 \\
600 \\
395 \\
310\end{array}$ & $\begin{array}{l}7.50 \\
7.40 \\
7.40 \\
7.50 \\
8.00\end{array}$ & $\begin{array}{l}08-13-85 \\
08-07-85 \\
08-08-85 \\
08-15-85 \\
08-08-85\end{array}$ & $\begin{array}{l}\text { SP11 } \\
\text { SP14 } \\
\text { SP17 } \\
\text { SP18 } \\
\text { SP19 }\end{array}$ \\
\hline $\begin{array}{r}11 \\
57 \\
<10 \\
<10\end{array}$ & $\begin{array}{l}<.1 \\
<.17 \\
<.1 \\
<.1\end{array}$ & $\begin{array}{l}-- \\
-- \\
-- \\
--\end{array}$ & $\begin{array}{l}.001 \\
<.001 \\
<.001 \\
<.001\end{array}$ & $\begin{array}{l}5.72 \\
2.86 \\
3.74 \\
5.06\end{array}$ & $\begin{array}{l}.002 \\
.004 \\
.003 \\
.002\end{array}$ & $\begin{array}{l}260 \\
260 \\
150 \\
220\end{array}$ & $\begin{array}{l}352 \\
308 \\
184 \\
366\end{array}$ & $\begin{array}{l}525 \\
525 \\
345 \\
475\end{array}$ & $\begin{array}{l}7.10 \\
7.40 \\
7.50 \\
7.60\end{array}$ & $\begin{array}{l}08-14-85 \\
08-15-85 \\
08-14-85 \\
08-07-85\end{array}$ & $\begin{array}{l}\text { SP23 } \\
\text { SP24 } \\
\text { SP25 } \\
\text { SP32 }\end{array}$ \\
\hline - & \multicolumn{11}{|c|}{ Clinton County } \\
\hline $\begin{array}{l}20 \\
5.0 \\
5.0 \\
45 \\
25\end{array}$ & $\begin{array}{l}<.1 \\
<.1 \\
<.1 \\
<.1 \\
<.1\end{array}$ & $\begin{array}{l}.08 \\
.01 \\
.08 \\
.08 \\
.08\end{array}$ & $\begin{array}{l}.002 \\
.002 \\
.002 \\
.002 \\
.002\end{array}$ & $\begin{array}{c}1.44 \\
5.06 \\
3.74 \\
26.5 \\
3.96\end{array}$ & $\begin{array}{l}-- \\
-- \\
-- \\
-- \\
--\end{array}$ & $\begin{array}{l}150 \\
140 \\
130 \\
370 \\
290\end{array}$ & $\begin{array}{l}240 \\
220 \\
200 \\
580 \\
438\end{array}$ & $\begin{array}{l}-- \\
-- \\
-- \\
-- \\
--\end{array}$ & $\begin{array}{l}-- \\
-- \\
-- \\
-- \\
--\end{array}$ & $\begin{array}{l}06-09-81 \\
06-08-81 \\
06-08-81 \\
06-09-81 \\
06-07-81\end{array}$ & $\begin{array}{l}156 \\
157 \\
159 \\
162 \\
167\end{array}$ \\
\hline $\begin{array}{c}25 \\
60 \\
10 \\
9.0 \\
13\end{array}$ & $\begin{array}{l}<.1 \\
<.1 \\
<.1 \\
<.1 \\
<.1\end{array}$ & $\begin{array}{l}.08 \\
.13 \\
.01 \\
.01 \\
.01\end{array}$ & $\begin{array}{l}.002 \\
.02 \\
.002 \\
.004 \\
.002\end{array}$ & $\begin{array}{r}3.08 \\
.94 \\
1.32 \\
4.18 \\
4.18\end{array}$ & $\begin{array}{l}-- \\
-- \\
-- \\
--\end{array}$ & $\begin{array}{l}250 \\
340 \\
140 \\
140 \\
270\end{array}$ & $\begin{array}{l}322 \\
464 \\
222 \\
176 \\
378\end{array}$ & $\begin{array}{l}-- \\
-- \\
-- \\
-- \\
--\end{array}$ & $\begin{array}{l}-- \\
-- \\
-- \\
-- \\
--\end{array}$ & $\begin{array}{l}06-09-81 \\
06-10-81 \\
06-16-81 \\
06-17-81 \\
06-17-81\end{array}$ & $\begin{array}{l}169 \\
172 \\
277 \\
283 \\
284\end{array}$ \\
\hline
\end{tabular}


Table 8.--Chemical analyses of major constituents in well and spring water--Continued

\begin{tabular}{|c|c|c|c|c|c|c|c|c|c|c|c|}
\hline $\begin{array}{l}\text { County } \\
\text { well or } \\
\text { spring } \\
\text { number }\end{array}$ & Date & $\begin{array}{l}\text { Geo- } \\
\text { logic } \\
\text { unit }\end{array}$ & $\begin{array}{c}\text { Temper- } \\
\text { ature } \\
\text { (*C) }\end{array}$ & $\begin{array}{l}\text { Iron, } \\
\text { dis- } \\
\text { solved } \\
(\mu 8 / L \\
\left.\text { as } F_{\theta}\right)\end{array}$ & $\begin{array}{l}\text { Manga- } \\
\text { nese, } \\
\text { dis- } \\
\text { solved } \\
(\mu g / L \\
\text { as Mn) }\end{array}$ & $\begin{array}{l}\text { Calcium, } \\
\text { dis- } \\
\text { solved } \\
\text { (ms/L } \\
\text { as } \mathrm{Ca} \text { ) }\end{array}$ & $\begin{array}{l}\text { Magne- } \\
\text { sium, } \\
\text { dis- } \\
\text { solved } \\
\text { (mg/L } \\
\text { as } M 8 \text { ) }\end{array}$ & $\begin{array}{l}\text { Sodium, } \\
\text { dis- } \\
\text { solved } \\
\text { (mg/L } \\
\text { as } \mathrm{Na} \text { ) }\end{array}$ & $\begin{array}{l}\text { Potas- } \\
\text { sium, } \\
\text { dis- } \\
\text { solved } \\
(\mathrm{mg} / \mathrm{L} \\
\text { as } K \text { ) }\end{array}$ & $\begin{array}{l}\text { Alka- } \\
\text { linity } \\
\text { lab } \\
(\mathrm{mg} / \mathrm{L} \\
\text { as } \mathrm{CaCO}_{3} \text { ) }\end{array}$ & $\begin{array}{l}\text { Chlo- } \\
\text { ride, } \\
\text { dis- } \\
\text { solved } \\
\text { (mg/L } \\
\text { as Cl) }\end{array}$ \\
\hline \multicolumn{12}{|c|}{ Clinton County--Continued } \\
\hline $\begin{array}{l}285 \\
297 \\
298 \\
353\end{array}$ & $\begin{array}{l}06-17-81 \\
06-23-81 \\
06-23-81 \\
06-25-85\end{array}$ & $\begin{array}{l}\text { Obf } \\
\text { Ocn } \\
\text { Obl } \\
\text { Obl }\end{array}$ & $\begin{array}{l}-- \\
-- \\
-5\end{array}$ & $\begin{array}{r}<1 \\
<1 \\
1 \\
31\end{array}$ & $\begin{array}{r}<1 \\
<1 \\
<1 \\
<10\end{array}$ & $\begin{array}{l}69 \\
65 \\
38 \\
35\end{array}$ & $\begin{array}{l}30 \\
3.6 \\
11 \\
2.7\end{array}$ & $\begin{array}{l}1.1 \\
5.6 \\
0.6 \\
4.9\end{array}$ & $\begin{array}{l}0.8 \\
1.0 \\
.52 \\
1.0\end{array}$ & $\begin{array}{l}256 \\
150 \\
128 \\
100\end{array}$ & $\begin{array}{r}4.0 \\
8.0 \\
2.0 \\
21\end{array}$ \\
\hline $\begin{array}{l}354 \\
359 \\
375 \\
376 \\
\text { SP2 }\end{array}$ & $\begin{array}{l}06-25-85 \\
06-25-85 \\
06-24-85 \\
06-25-85 \\
08-13-85\end{array}$ & $\begin{array}{l}\text { Obf } \\
\text { Obf } \\
\text { Obf } \\
\text { Oa } \\
\text { Obf }\end{array}$ & $\begin{array}{l}11.5 \\
12.5 \\
12.0 \\
13.0 \\
15.0\end{array}$ & $\begin{array}{r}<10 \\
<10 \\
<10 \\
25 \\
34\end{array}$ & $\begin{array}{r}<10 \\
<10 \\
14 \\
<10 \\
<10\end{array}$ & $\begin{array}{r}66 \\
130 \\
54 \\
29 \\
35\end{array}$ & $\begin{array}{c}37 \\
6.7 \\
28 \\
17 \\
11\end{array}$ & $\begin{array}{r}7.0 \\
6.8 \\
8.9 \\
.5 \\
2.9\end{array}$ & $\begin{array}{c}2.2 \\
49^{.7} \\
.7 \\
.66\end{array}$ & $\begin{array}{l}274 \\
314 \\
418 \\
154 \\
114\end{array}$ & $\begin{array}{r}19 \\
22 \\
68 \\
4.0 \\
9.0\end{array}$ \\
\hline $\begin{array}{l}\text { SP12 } \\
\text { SP17 } \\
\text { SP21 }\end{array}$ & $\begin{array}{l}08-12-85 \\
08-14-85 \\
08-14-85\end{array}$ & $\begin{array}{l}\text { Oa-Obf } \\
\text { Och } \\
\text { Obl }\end{array}$ & $\begin{array}{l}13.0 \\
14.0 \\
14.0\end{array}$ & $\begin{array}{l}<10 \\
<10 \\
<10\end{array}$ & $\begin{array}{l}<10 \\
<10 \\
<10\end{array}$ & $\begin{array}{l}30 \\
36 \\
40\end{array}$ & $\begin{array}{l}14 \\
10 \\
12\end{array}$ & $\begin{array}{l}.99 \\
3.2 \\
3.5\end{array}$ & $\begin{array}{l}.54 \\
.5 \\
.54\end{array}$ & $\begin{array}{l}124 \\
118 \\
126\end{array}$ & $\begin{array}{l}4.0 \\
10^{4}\end{array}$ \\
\hline \multicolumn{12}{|c|}{ Buntingdon County } \\
\hline $\begin{array}{l}119 \\
200 \\
263 \\
275 \\
350\end{array}$ & $\begin{array}{l}06-05-80 \\
07-15-80 \\
07-16-80 \\
06-17-85 \\
06-19-85\end{array}$ & $\begin{array}{l}\text { On } \\
\text { Os } \\
\text { Ocl } \\
\text { Os } \\
\text { C } 1\end{array}$ & $\begin{array}{r}-- \\
14.0 \\
14.0 \\
1.0 \\
1.5\end{array}$ & $\begin{array}{r}110 \\
10 \\
190 \\
<10 \\
1,300\end{array}$ & $\begin{array}{r}10 \\
-- \\
10 \\
<10 \\
<10\end{array}$ & $\begin{array}{l}35 \\
41 \\
36 \\
56 \\
42\end{array}$ & $\begin{array}{l}20 \\
23 \\
22 \\
20 \\
23\end{array}$ & $\begin{array}{r}4.5 \\
4.5 \\
29 \\
1.1 \\
1.6\end{array}$ & $\begin{array}{l}.4 \\
-- \\
-8 \\
.2\end{array}$ & $\begin{array}{l}180 \\
180 \\
260 \\
192 \\
186\end{array}$ & $\begin{array}{r}2.0 \\
8.0 \\
16 \\
6.0 \\
6.0\end{array}$ \\
\hline $\begin{array}{l}357 \\
394 \\
\text { SP1 } \\
\text { SP2 } \\
\text { SP13 }\end{array}$ & $\begin{array}{l}06-19-85 \\
06-11-85 \\
08-06-85 \\
08-09-85 \\
08-09-85\end{array}$ & $\begin{array}{l}\text { On } \\
\text { Oba } \\
\text { Obf } \\
\text { Cgm } \\
\text { Obl }\end{array}$ & $\begin{array}{r}1.0 \\
13.5 \\
12.0 \\
11.0 \\
12.0\end{array}$ & $\begin{array}{r}86 \\
<10 \\
82 \\
<10 \\
<10\end{array}$ & $\begin{array}{r}<10 \\
<10 \\
28 \\
<10 \\
10\end{array}$ & $\begin{array}{l}49 \\
46 \\
28 \\
33 \\
60\end{array}$ & $\begin{array}{r}27 \\
28 \\
16 \\
17 \\
4.3\end{array}$ & $\begin{array}{l}1.0 \\
1.2 \\
1.0 \\
.59 \\
1.5\end{array}$ & $\begin{array}{l}1.4 \\
1.0 \\
.48 \\
.43 \\
.68\end{array}$ & $\begin{array}{l}198 \\
206 \\
124 \\
142 \\
146\end{array}$ & $\begin{array}{r}10 \\
6.0 \\
4.0 \\
3.0 \\
5.0\end{array}$ \\
\hline \multicolumn{12}{|c|}{ Mifflin County } \\
\hline $\begin{array}{l}241 \\
272 \\
273 \\
275 \\
321\end{array}$ & $\begin{array}{l}07-23-80 \\
07-19-84 \\
07-16-84 \\
07-30-80 \\
07-17-84\end{array}$ & $\begin{array}{l}\text { Obf } \\
\text { Obf } \\
\text { Obf } \\
\text { Obf } \\
\text { obf }\end{array}$ & $\begin{array}{l}15.0 \\
14.0 \\
12.0 \\
13.0 \\
13.0\end{array}$ & $\begin{array}{r}20 \\
2,700 \\
100 \\
30 \\
<100\end{array}$ & $\begin{array}{r}500 \\
<50 \\
20 \\
<100\end{array}$ & $\begin{array}{l}58 \\
96 \\
71 \\
76 \\
58\end{array}$ & $\begin{array}{l}28 \\
36 \\
28 \\
35 \\
31\end{array}$ & $\begin{array}{r}6.4 \\
26 \\
27 \\
7.5 \\
.7\end{array}$ & $\begin{array}{l}1.0 \\
4.9 \\
3.1 \\
2.0 \\
1.3\end{array}$ & $\begin{array}{l}200 \\
348 \\
226 \\
350 \\
234\end{array}$ & $\begin{array}{r}20 \\
42 \\
41 \\
24 \\
5.0\end{array}$ \\
\hline $\begin{array}{l}329 \\
339 \\
349 \\
353 \\
362\end{array}$ & $\begin{array}{l}07-23-84 \\
07-23-84 \\
07-17-84 \\
07-18-84 \\
07-17-84\end{array}$ & $\begin{array}{l}\text { Obl } \\
\text { Obf } \\
\text { Obf } \\
\text { Ocn } \\
\text { Obl }\end{array}$ & $\begin{array}{l}11.5 \\
11.5 \\
12.0 \\
12.0 \\
13.5\end{array}$ & $\begin{array}{r}1,500 \\
<100 \\
<100 \\
100 \\
<100\end{array}$ & $\begin{array}{l}<50 \\
<50 \\
<100 \\
<100 \\
<100\end{array}$ & $\begin{array}{l}89 \\
66 \\
86 \\
90 \\
78\end{array}$ & $\begin{array}{c}17 \\
35 \\
34 \\
7.4 \\
28\end{array}$ & $\begin{array}{r}2.9 \\
6.3 \\
13 \\
1.2 \\
4.9\end{array}$ & $\begin{array}{r}.9 \\
1.4 \\
6.3 \\
.5 \\
1.1\end{array}$ & $\begin{array}{l}226 \\
232 \\
266 \\
238 \\
248\end{array}$ & $\begin{array}{l}5.0 \\
19 \\
30 \\
3.0 \\
13\end{array}$ \\
\hline $\begin{array}{l}367 \\
389 \\
394 \\
\text { SP2 } \\
\text { SP3 }\end{array}$ & $\begin{array}{l}07-17-84 \\
07-18-84 \\
07-18-84 \\
08-22-85 \\
08-22-85\end{array}$ & $\begin{array}{l}O b l \\
O b f \\
O b 1 \\
O a \\
O b l\end{array}$ & $\begin{array}{l}12.0 \\
11.5 \\
13.0 \\
11.0 \\
16.5\end{array}$ & $\begin{array}{r}300 \\
<100 \\
100 \\
120 \\
210\end{array}$ & $\begin{array}{r}300 \\
<100 \\
100 \\
<10 \\
19\end{array}$ & $\begin{array}{r}120 \\
87 \\
150 \\
71 \\
34\end{array}$ & $\begin{array}{r}7.7 \\
48 \\
17 \\
0.8 \\
.8\end{array}$ & $\begin{array}{r}34 \\
4.1 \\
9.8 \\
2.0 \\
1.5\end{array}$ & $\begin{array}{l}1.0 \\
2.8 \\
5.4 \\
.82 \\
.76\end{array}$ & $\begin{array}{r}260 \\
332 \\
362 \\
194 \\
86\end{array}$ & $\begin{array}{r}94 \\
10 \\
34 \\
9.0 \\
8.0\end{array}$ \\
\hline
\end{tabular}

1 Och: Coburn, Salona, and Nealmont Formations; Obl: Benner, Snyder, Hatter, and Loysburg Formations; Oc1: Coburn through Loysburg Formations; Obf: Bellefonte Formation; Oa: Axemann Formation; Oba: Bellefonte and Axemann Formations; On: Nittany Formation; Onl: Nittany and Larke Formations; Os: Stonehenge Formation; $C_{8}$ : Gatesburg Formation; Cgm: Mines Member of Gatesburg Formation; $C_{8} 1$ : lower members of Gatesburg Formation; $C_{w}$ : Warrior Formation 
Table 8.--Chemical analyses of major constituents in well and spring water--Continued

\begin{tabular}{|c|c|c|c|c|c|c|c|c|c|c|c|}
\hline $\begin{array}{l}\text { Sulfate, } \\
\text { dis- } \\
\text { solved } \\
\text { (mg/L } \\
\text { as } \mathrm{SO}_{4} \text { ) }\end{array}$ & $\begin{array}{l}\text { Fluo- } \\
\text { ride, } \\
\text { dis- } \\
\text { solved } \\
\text { (mg/L } \\
\text { as F) }\end{array}$ & $\begin{array}{l}\text { Nitro- } \\
\text { gen, } \\
\text { ammonia } \\
\text { dis- } \\
\text { solved } \\
\text { (mg/L } \\
\text { as N) }\end{array}$ & $\begin{array}{l}\text { Nitro- } \\
\text { gen, } \\
\text { nitrite } \\
\text { dis- } \\
\text { solved } \\
\text { (mg/L } \\
\text { as } N \text { ) }\end{array}$ & $\begin{array}{l}\text { Nitro- } \\
\text { gen, } \\
\text { nitrate } \\
\text { dis- } \\
\text { solved } \\
\text { (mg/L } \\
\text { as } N \text { ) }\end{array}$ & $\begin{array}{l}\text { Phos- } \\
\text { phorus, } \\
\text { ortho, } \\
\text { dis- } \\
\text { solved } \\
\text { (mg/L } \\
\text { as } P \text { ) }\end{array}$ & $\begin{array}{l}\text { Hard- } \\
\text { ness } \\
\text { (mg/L } \\
\text { as } \\
\mathrm{CaCO}_{3} \text { ) }\end{array}$ & $\begin{array}{l}\text { Solids, } \\
\text { residdue } \\
\text { at. } 105 \\
\text { dis- } \\
\text { dis- } \\
\text { solved } \\
\text { (mg/L) }\end{array}$ & $\begin{array}{l}\text { Spe- } \\
\text { cific } \\
\text { con- } \\
\text { duct- } \\
\text { ance } \\
(\mu \mathrm{S} / \mathrm{cm})\end{array}$ & $\begin{array}{l}\mathrm{pH} \\
\text { (stand- } \\
\text { ard } \\
\text { units) }\end{array}$ & Date & $\begin{array}{l}\text { County } \\
\text { well or } \\
\text { spring } \\
\text { number }\end{array}$ \\
\hline \multicolumn{12}{|c|}{ Clinton County--Continued } \\
\hline $\begin{array}{r}33 \\
5.0 \\
5.0 \\
13\end{array}$ & $\begin{array}{c}0.1 \\
.13 \\
.1 \\
<.1\end{array}$ & $\begin{array}{r}0.01 \\
.08 \\
.01 \\
--\end{array}$ & $\begin{array}{r}0.002 \\
.002 \\
.002 \\
<.001\end{array}$ & $\begin{array}{r}0.16 \\
5.94 \\
.32 \\
3.50\end{array}$ & $\begin{array}{r}=- \\
\overline{-} \\
0.006\end{array}$ & $\begin{array}{r}290 \\
180 \\
140 \\
99\end{array}$ & $\begin{array}{l}346 \\
240 \\
174 \\
216\end{array}$ & $\begin{array}{l}-- \\
-- \\
295\end{array}$ & $\begin{array}{l}-- \\
\overline{--} \\
7.50\end{array}$ & $\begin{array}{l}06-17-81 \\
06-23-81 \\
06-23-81 \\
06-25-85\end{array}$ & $\begin{array}{l}285 \\
297 \\
298 \\
353\end{array}$ \\
\hline $\begin{array}{l}41 \\
33 \\
77 \\
13 \\
11\end{array}$ & $\begin{array}{l}<.1 \\
.1 \\
<.1 \\
<.1 \\
<.1\end{array}$ & $\begin{array}{l}-- \\
-- \\
-- \\
--\end{array}$ & $\begin{array}{l}<.001 \\
<.001 \\
<.001 \\
<.001 \\
<.001\end{array}$ & $\begin{array}{c}14.3 \\
8.10 \\
18.3 \\
2.50 \\
1.88\end{array}$ & $\begin{array}{l}.006 \\
.008 \\
.015 \\
.007 \\
.002\end{array}$ & $\begin{array}{l}320 \\
340 \\
250 \\
150 \\
130\end{array}$ & $\begin{array}{l}540 \\
484 \\
776 \\
194 \\
172\end{array}$ & $\begin{array}{r}705 \\
725 \\
>1,000 \\
320 \\
290\end{array}$ & $\begin{array}{l}7.20 \\
7.00 \\
7.00 \\
7.90 \\
7.70\end{array}$ & $\begin{array}{l}06-25-85 \\
06-25-85 \\
06-24-85 \\
06-25-85 \\
08-13-85\end{array}$ & $\begin{array}{l}354 \\
359 \\
375 \\
376 \\
\text { SP2 }\end{array}$ \\
\hline $\begin{array}{r}<10 \\
14 \\
14\end{array}$ & $\begin{array}{l}<.1 \\
<.1 \\
<.1\end{array}$ & $\begin{array}{l}-- \\
--\end{array}$ & $\begin{array}{l}<.001 \\
<.001 \\
<.001\end{array}$ & $\begin{array}{l}1.76 \\
2.64 \\
3.30\end{array}$ & $\begin{array}{l}.003 \\
.002 \\
.002\end{array}$ & $\begin{array}{l}130 \\
130 \\
150\end{array}$ & $\begin{array}{l}154 \\
180 \\
202\end{array}$ & $\begin{array}{l}275 \\
315 \\
350\end{array}$ & $\begin{array}{l}8.00 \\
7.80 \\
7.70\end{array}$ & $\begin{array}{l}08-12-85 \\
08-14-85 \\
08-14-85\end{array}$ & $\begin{array}{l}\text { SP12 } \\
\text { SP17 } \\
\text { SP21 }\end{array}$ \\
\hline \multicolumn{12}{|c|}{ Huntingdon County } \\
\hline $\begin{array}{l}20 \\
10 \\
30 \\
20 \\
23\end{array}$ & $\begin{array}{r}<.1 \\
<.1 \\
1.5 \\
.1 \\
.1\end{array}$ & $\begin{array}{r}.01 \\
.02 \\
1.70 \\
-- \\
--\end{array}$ & $\begin{array}{l}<.01 \\
<.01 \\
<.01 \\
<.001 \\
<.001\end{array}$ & $\begin{array}{l}1.60 \\
7.60 \\
.01 \\
5.50 \\
5.30\end{array}$ & $\begin{array}{r}-- \\
-- \\
.002 \\
<.002\end{array}$ & $\begin{array}{l}170 \\
200 \\
180 \\
220 \\
200\end{array}$ & $\begin{array}{l}204 \\
248 \\
406 \\
280 \\
290\end{array}$ & $\begin{array}{l}320 \\
420 \\
415 \\
400\end{array}$ & $\begin{array}{r}-- \\
-- \\
8.90 \\
7.60 \\
7.70\end{array}$ & $\begin{array}{l}06-05-80 \\
07-15-80 \\
07-16-80 \\
06-17-85 \\
06-19-85\end{array}$ & $\begin{array}{l}119 \\
200 \\
263 \\
275 \\
350\end{array}$ \\
\hline $\begin{array}{r}22 \\
17 \\
<10 \\
<10 \\
14\end{array}$ & $\begin{array}{l}<.1 \\
<.1 \\
<.1 \\
<.1 \\
<.1\end{array}$ & $\begin{array}{l}-- \\
-- \\
-- \\
--\end{array}$ & $\begin{array}{l}<.001 \\
<.001 \\
<.001 \\
<.001 \\
<.001\end{array}$ & $\begin{array}{l}6.80 \\
9.00 \\
2.86 \\
3.74 \\
4.40\end{array}$ & $\begin{array}{l}.002 \\
.003 \\
.003 \\
.002 \\
.02\end{array}$ & $\begin{array}{l}230 \\
230 \\
130 \\
150 \\
170\end{array}$ & $\begin{array}{l}358 \\
298 \\
256 \\
268 \\
304\end{array}$ & $\begin{array}{l}450 \\
480 \\
280 \\
157 \\
360\end{array}$ & $\begin{array}{l}7.60 \\
7.50 \\
7.90 \\
7.80 \\
7.40\end{array}$ & $\begin{array}{l}06-19-85 \\
06-11-85 \\
08-06-85 \\
08-09-85 \\
08-09-85\end{array}$ & $\begin{array}{l}357 \\
394 \\
\text { SP1 } \\
\text { SP2 } \\
\text { SP13 }\end{array}$ \\
\hline \multicolumn{12}{|c|}{ Mifflin County } \\
\hline $\begin{array}{l}20 \\
50 \\
75 \\
30 \\
33\end{array}$ & $\begin{array}{l}<.1 \\
.08 \\
.08 \\
.5 \\
.14\end{array}$ & $\begin{array}{l}.02 \\
-- \\
-01 \\
.01\end{array}$ & $\begin{array}{l}<.01 \\
<.01 \\
<.01 \\
<.01 \\
.01\end{array}$ & $\begin{array}{l}.066 \\
-. \\
3.60 \\
8.40 \\
3.72\end{array}$ & $\begin{array}{l}.009 \\
.00 \\
.18 \\
-\overline{002}\end{array}$ & $\begin{array}{l}260 \\
390 \\
290 \\
330 \\
270\end{array}$ & $\begin{array}{l}506 \\
478 \\
536 \\
336\end{array}$ & $\begin{array}{l}480 \\
920 \\
650 \\
810 \\
530\end{array}$ & $\begin{array}{r}7.20 \\
6.90 \\
7.30 \\
-- \\
7.20\end{array}$ & $\begin{array}{l}07-23-80 \\
07-19-84 \\
07-16-84 \\
07-30-80 \\
07-17-84\end{array}$ & $\begin{array}{l}241 \\
272 \\
273 \\
275 \\
321\end{array}$ \\
\hline $\begin{array}{l}85 \\
43 \\
63 \\
50 \\
55\end{array}$ & $\begin{array}{c}.01 \\
<.01 \\
.1 \\
.07 \\
.2\end{array}$ & $\begin{array}{l}-- \\
-- \\
-- \\
--\end{array}$ & $\begin{array}{l}<.01 \\
<.01 \\
<.01 \\
<.01 \\
<.01\end{array}$ & $\begin{array}{c}1.75 \\
11.0 \\
15.1 \\
4.18 \\
1.8\end{array}$ & $\begin{array}{r}.001 \\
<.001 \\
.002 \\
.003 \\
.006\end{array}$ & $\begin{array}{l}290 \\
310 \\
360 \\
250 \\
310\end{array}$ & $\begin{array}{l}368 \\
424 \\
568 \\
364 \\
484\end{array}$ & $\begin{array}{l}520 \\
560 \\
745 \\
510 \\
615\end{array}$ & $\begin{array}{l}7.80 \\
7.40 \\
7.00 \\
7.20 \\
6.90\end{array}$ & $\begin{array}{l}07-23-84 \\
07-23-84 \\
07-17-84 \\
07-18-84 \\
07-17-84\end{array}$ & $\begin{array}{l}329 \\
339 \\
349 \\
353 \\
362\end{array}$ \\
\hline $\begin{array}{l}50 \\
63 \\
70 \\
20 \\
12\end{array}$ & $\begin{array}{r}.08 \\
.09 \\
.09 \\
<.1 \\
<.1\end{array}$ & $\begin{array}{l}-- \\
-- \\
-- \\
--\end{array}$ & $\begin{array}{l}<.01 \\
<.01 \\
<.01 \\
<.001 \\
<.001\end{array}$ & $\begin{array}{r}11.9 \\
9.90 \\
8.14 \\
7.55 \\
.95\end{array}$ & $\begin{array}{l}.003 \\
.015 \\
.008 \\
.01 \\
.006\end{array}$ & $\begin{array}{r}340 \\
410 \\
430 \\
180 \\
89\end{array}$ & $\begin{array}{l}642 \\
552 \\
614 \\
298 \\
132\end{array}$ & $\begin{array}{l}790 \\
710 \\
845 \\
460 \\
215\end{array}$ & $\begin{array}{l}6.80 \\
7.40 \\
6.90 \\
7.70 \\
7.80\end{array}$ & $\begin{array}{l}07-17-84 \\
07-18-84 \\
07-18-84 \\
08-22-85 \\
08-22-85\end{array}$ & $\begin{array}{l}367 \\
389 \\
394 \\
\text { SP2 } \\
\text { SP3 }\end{array}$ \\
\hline
\end{tabular}




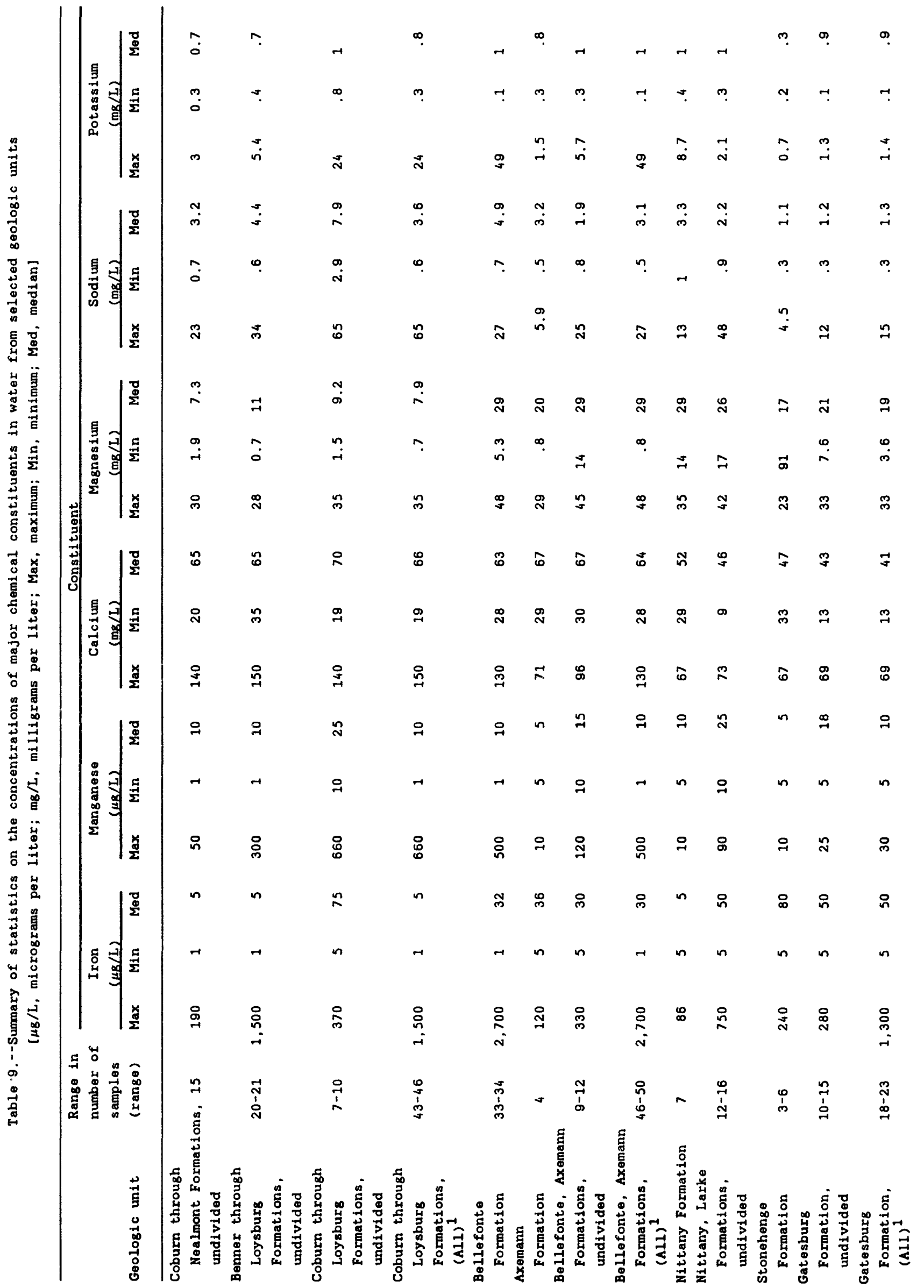




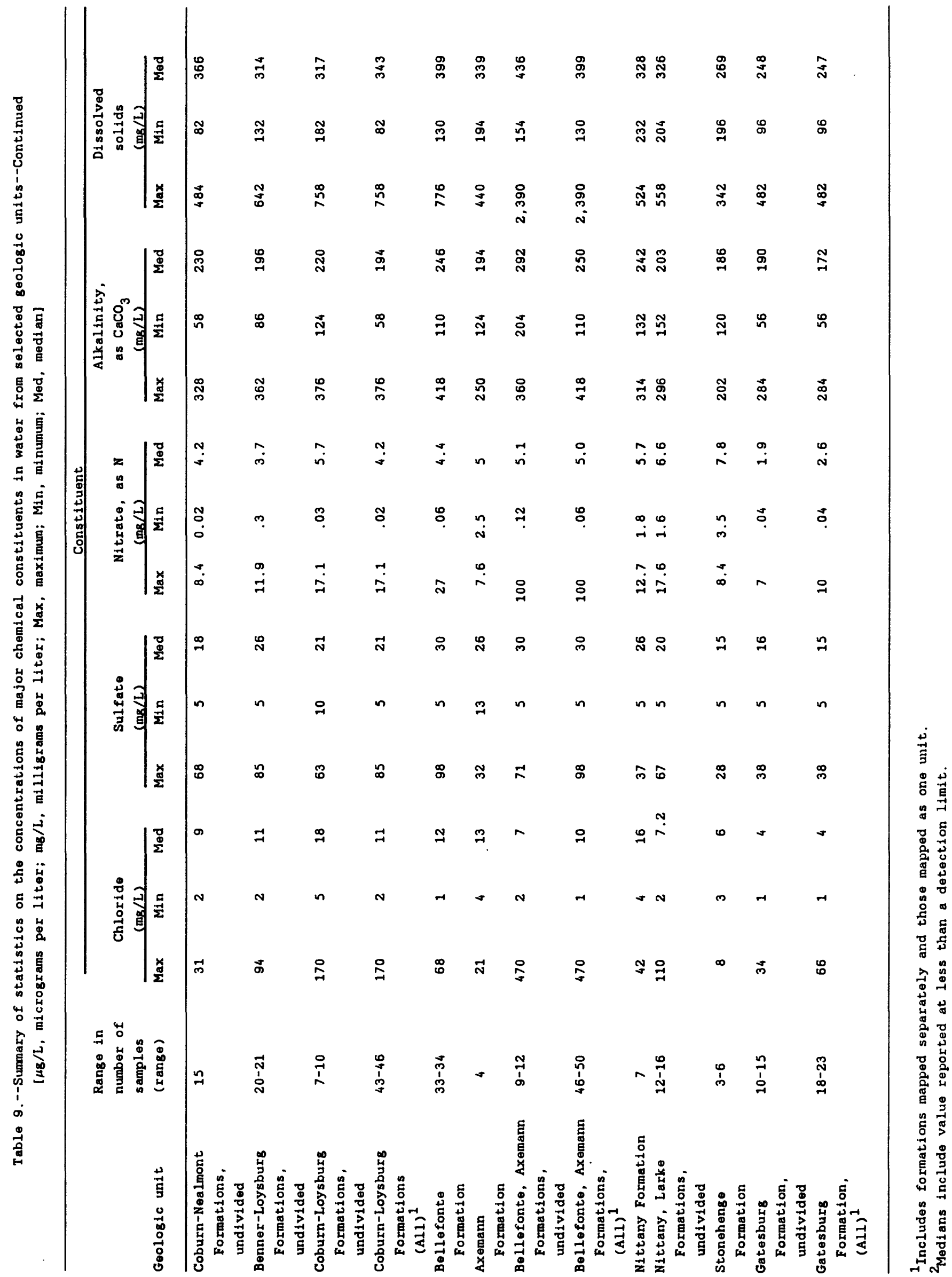




\section{Iron and Manganese}

The concentration of iron exceeds the USEPA's SMCL of $300 \mu \mathrm{g} / \mathrm{L}(0.3 \mathrm{mg} / \mathrm{L})$ in 12 of 148 sample analyses. Manganese concentrations exceed the SMCL of 50 $\mu \mathrm{g} / \mathrm{L}(0.05 \mathrm{mg} / \mathrm{L})$ in 6 of 141 samples analyzed. Iron and manganese are similar geochemically in the ground-water environment. They are leached from rock and soil under acidic conditions, but iron also is commonly stripped from pipes in water-distribution systems. Although not toxic at SMCL levels, both impart an unpleasant taste to water and stain clothing, dishes, and porcelain.

Concentrations in most samples that exceed SMCLs exceed them only slightly. One of the four samples that greatly exceeded the SMCL for iron is from a well that is contaminated by a leaking gasoline tank (Mf 272). Water from soil that has been leached by gasoline is known to contain elevated levels of iron and manganese (Becher and Root, 1981). Of the remaining samples, two (Ce 447, Cn 350) are from wells on the flank of a mountain ridge and probably receive iron dissolved by acidic water percolating through sandstone. Iron in the fourth sample (Mf 329) is of local origin and may be coming from a waterdistribution system.

\section{Dissolved solids}

Nineteen of the 146 samples analyzed contained dissolved solids greater than the $500 \mathrm{mg} / \mathrm{L}$ SMCL recommended by the USEPA (1977b). Elevated concentrations do not pose any health problems and are acceptable if water with dissolved-solid concentrations that meet the SMCL is not available. Most samples containing elevated concentrations of dissolved solids also have elevated concentrations of chloride, sulfate, and nitrate. A few samples were from wells known to have been contaminated by gasoline or pesticides. The average dissolved-solids concentration in natural water in carbonate rocks of these valleys probably is slightly less than $400 \mathrm{mg} / \mathrm{L}$. Therefore, little additional mineral matter need be dissolved to increase the total above the SMCL for dissolved solids. 
Elevated concentrations of nitrate in ground water of agricultural areas are largely caused by fertilizers, although septic tank effluents upgradient from wells may also be contributors. Concentrations of nitrate in 17 of 146 sample analyses exceed the MCL of $10 \mathrm{mg} / \mathrm{L}$ (nitrate as $\mathrm{N}$ ) for drinking water. Water from the Gatesburg Formation has the lowest concentration of nitrate; the median is $2 \mathrm{mg} / \mathrm{L}$. Gatesburg Formation terrane also has the least amount of cropland. The median values of all other geologic units range from a low of 3.7 in the Coburn through Nealmont Formations (carbonate unit bordering the noncarbonate terrane) to a high of $7.1 \mathrm{mg} / \mathrm{L}$ in the undivided Bellefonte and Axemann Formations. Ground-water from Kishacoquillas Valley has the highest nitrate concentration of all the valleys. The median here is $5.9 \mathrm{mg} / \mathrm{L}$, but 25 percent of the samples have nitrate concentrations that exceeded $10 \mathrm{mg} / \mathrm{L}$. Median nitrate concentrations for the southern part of the Nittany Valley (south of the Huntingdon-Centre County line) and the Morrison Cove and Canoe Valley are 5.3 and $4.9 \mathrm{mg} / \mathrm{L}$, respectively. In contrast, the median concentration of nitrate in the northern part of the Nittany, Penns, Brush, and Sugar Valleys combined is only $3.3 \mathrm{mg} / \mathrm{L}$. The median concentration of nitrate in Snake Spring Valley is only $3.8 \mathrm{mg} / \mathrm{L}$.

\section{Trace Elements}

Ground-water samples were analyzed for selected elements, normally found in trace amounts only, to determine natural concentrations and areas of anomalously elevated concentrations. Of the 122 trace-element analyses shown in table 10, 41 were for samples collected in 1980 and 1981 for an earlier study (Taylor and others, 1982) and 81 were for samples collected during this study. The metals selected for analysis are arsenic, barium, cadmium, chromium, lead, nickel, strontium, zinc, and aluminum.

None of the samples contained concentrations in excess of the MCL set by the USEPA (1986a) of $1,000 \mu \mathrm{g} / \mathrm{L}$ for barium and $10 \mu \mathrm{g} / \mathrm{L}$ for cadmium. The concentration of lead in one sample slightly exceeds the MCL of $50 \mu \mathrm{g} / \mathrm{L}$. Although no health-related standards exist for strontium and aluminum, a concentration of $2,500 \mu \mathrm{g} / \mathrm{L}$ of strontium was found in one sample and a concentration of $2,500 \mu \mathrm{g} / \mathrm{L}$ of aluminum in another sample. The recommended SMCL (USEPA, 1986b) of $5,000 \mu \mathrm{g} / \mathrm{L}$ for zinc was exceeded in one sample. Arsenic and chromium were not found in concentrations that exceed the USEPA MCL of $50 \mu \mathrm{g} / \mathrm{L}$ (1986a). Some concentrations were reported as $<500$ or $<1,000$ $\mu \mathrm{g} / \mathrm{L}$ for arsenic and $<70 \mu \mathrm{g} / \mathrm{L}$ for chromium because of the detection limits of the laboratory equipment used.

Zinc and lead were not detected in water from the two wells ( $\mathrm{Ba} 608$ and 610) near the southern end of the Nittany Valley, where noneconomic deposits of these metals have been found (R.C. Smith, 1977). A detailed study, based on more extensive sampling, both areally and temporally (Cravotta, 1986), revealed low levels of $\mathrm{zinc}$ and lead, well below the MCLs for these metals in potable water, in all water samples. 
Table 10.--Chemical analyses of trace metals in well and spring water

[ $\mu \mathrm{g} / \mathrm{L}$, micrograms per liter; <, less than; --, no data]

\begin{tabular}{|c|c|c|c|c|c|c|c|c|c|c|c|}
\hline $\begin{array}{l}\text { County } \\
\text { well or } \\
\text { spring } \\
\text { number }\end{array}$ & Date & $\underset{\text { unit }^{\text {Geologic }}}{c}$ & $\begin{array}{l}\text { Arsentc, } \\
\text { dis- } \\
\text { solved } \\
\text { ( } \mu g / L \\
\text { as As ) }\end{array}$ & $\begin{array}{l}\text { Barium, } \\
\text { dis- } \\
\text { solvad } \\
(\mu \mathrm{g} / \mathrm{L} \\
\text { as } \mathrm{Ba})\end{array}$ & $\begin{array}{c}\text { Cadmium, } \\
\text { dis- } \\
\text { solvad } \\
\text { ( } \mu \mathrm{g} / \mathrm{L} \\
\text { as Cd) }\end{array}$ & $\begin{array}{l}\text { Chro- } \\
\text { mium, } \\
\text { dis- } \\
\text { solved } \\
\text { ( } \mu g / L \\
\text { as } \mathrm{Cr})\end{array}$ & $\begin{array}{l}\text { Lead, } \\
\text { dis- } \\
\text { solved } \\
(\mu \mathrm{g} / \mathrm{L} \\
\text { as } \mathrm{Pb})\end{array}$ & $\begin{array}{l}\text { Nickel, } \\
\text { dis- } \\
\text { solved } \\
(\mu 8 / L \\
\text { as Ni) }\end{array}$ & $\begin{array}{l}\text { Stron- } \\
\text { tium, } \\
\text { dis- } \\
\text { solved } \\
(\mu g / L \\
\text { as } \mathrm{Sr})\end{array}$ & $\begin{array}{l}\text { Zinc, } \\
\text { dis- } \\
\text { solved } \\
(\mu g / L \\
\text { as } Z n)\end{array}$ & $\begin{array}{l}\text { Alumi- } \\
\text { num, } \\
\text { dis- } \\
\text { solved } \\
\text { ( } \mu 8 / L \\
\text { as } A l)\end{array}$ \\
\hline
\end{tabular}

\begin{tabular}{|c|c|c|c|c|c|c|c|c|c|c|c|}
\hline \multicolumn{12}{|c|}{ Bedford County } \\
\hline $\begin{array}{l}310 \\
314 \\
317 \\
389 \\
489 \\
508 \\
515 \\
531 \\
555 \\
608 \\
\text { SP26 } \\
\text { SP27 }\end{array}$ & $\begin{array}{l}08-20-80 \\
08-20-80 \\
08-21-80 \\
08-27-80 \\
09-18-80 \\
08-13-84 \\
08-14-84 \\
08-15-84 \\
08-15-84 \\
08-23-84 \\
07-31-85 \\
08-01-85\end{array}$ & $\begin{array}{l}\text { Oba } \\
O b a \\
C_{W} \\
C_{8} \\
C_{8} \\
\text { Ons } \\
\text { Ocn } \\
C_{W} \\
C_{8} \\
C_{8} \\
\text { Ons } \\
C_{8}\end{array}$ & $\begin{array}{r}-- \\
-- \\
-- \\
-- \\
<1 \\
<4 \\
<4 \\
<4 \\
<4 \\
-- \\
<1,000 \\
<1,000\end{array}$ & $\begin{array}{r}-- \\
-- \\
-- \\
-- \\
-- \\
110 \\
70 \\
230 \\
300 \\
200 \\
39 \\
41\end{array}$ & $\begin{array}{r}-- \\
-- \\
-- \\
-- \\
<1 \\
<1 \\
<1 \\
<1 \\
<- \\
<10 \\
<10\end{array}$ & $\begin{aligned} & 50 \\
& 40 \\
& 50 \\
&-- \\
& 10 \\
&<70 \\
&<70 \\
&<70 \\
&<70 \\
&<70 \\
&<50 \\
&<50\end{aligned}$ & $\begin{array}{r}-- \\
-- \\
-- \\
-- \\
\overline{28} \\
21 \\
<4 \\
8 \\
-- \\
<45 \\
<45\end{array}$ & $\begin{array}{r}20 \\
10 \\
-- \\
10 \\
10 \\
<140 \\
<140 \\
<140 \\
<140 \\
<140 \\
<25 \\
<25\end{array}$ & $\begin{array}{r}-- \\
-- \\
-- \\
-- \\
\overline{--} \\
70 \\
110 \\
50 \\
50 \\
330 \\
<10 \\
<10\end{array}$ & $\begin{array}{r}10 \\
20 \\
10 \\
620 \\
20 \\
70 \\
70 \\
10 \\
780 \\
950 \\
<10 \\
<10\end{array}$ & $\begin{array}{r}40 \\
40 \\
30 \\
30 \\
30 \\
<100 \\
100 \\
100 \\
100 \\
100 \\
<40 \\
<40\end{array}$ \\
\hline & \multicolumn{11}{|c|}{ Blair County } \\
\hline $\begin{array}{l}150 \\
223 \\
248 \\
254 \\
270 \\
272 \\
297 \\
298 \\
361 \\
362 \\
402 \\
423 \\
437 \\
444 \\
465 \\
479 \\
608 \\
610 \\
615 \\
519 \\
\text { SP12 } \\
\text { SP17 } \\
\text { SP20 }\end{array}$ & $\begin{array}{l}06-04-80 \\
06-10-80 \\
06-11-80 \\
06-16-80 \\
07-02-80 \\
07-02-80 \\
07-08-80 \\
07-08-80 \\
07-09-80 \\
07-09-80 \\
08-21-84 \\
08-20-84 \\
08-22-84 \\
08-20-84 \\
08-22-84 \\
08-21-84 \\
06-13-85 \\
06-11-85 \\
06-13-85 \\
06-11-85 \\
08-01-85 \\
08-01-85 \\
08-06-85\end{array}$ & $\begin{array}{l}C_{8} \\
\text { Oba } \\
\text { Ons } \\
C_{8 m} \\
\text { Oba } \\
\text { Ons } \\
\text { Ons } \\
\text { Oba } \\
\text { Ocl } \\
C_{8} \\
C_{8} \\
\text { Ons } \\
\text { Oba } \\
C_{8} \\
C_{8} \\
\text { Ons } \\
\text { Ocl } \\
\text { Ocl } \\
\text { Ons } \\
\text { Ons } \\
C_{8} \\
\text { On } \\
\text { Obf }\end{array}$ & $\begin{array}{r}-- \\
-- \\
-- \\
-- \\
-- \\
-- \\
<4 \\
-- \\
<4 \\
-- \\
<4 \\
<500 \\
<500 \\
<500 \\
<500 \\
<1,000 \\
<1,000 \\
<1,000\end{array}$ & $\begin{array}{r}-- \\
-- \\
-- \\
-- \\
-- \\
-- \\
-- \\
-- \\
-- \\
-- \\
<60 \\
80 \\
140 \\
<60 \\
<60 \\
60 \\
150 \\
45 \\
28 \\
10 \\
14 \\
22 \\
26\end{array}$ & $\begin{array}{r}-- \\
-- \\
-- \\
- \\
-- \\
-- \\
-- \\
-- \\
<1 \\
<1 \\
-- \\
<1 \\
- \\
3 \\
<10 \\
<10 \\
<10 \\
<10 \\
<10 \\
<10 \\
<10\end{array}$ & $\begin{array}{r}10 \\
-- \\
-- \\
-- \\
-- \\
-- \\
-- \\
-- \\
10 \\
<70 \\
<70 \\
<70 \\
<70 \\
<70 \\
<70 \\
<50 \\
<50 \\
<4 \\
<50 \\
<50 \\
<50 \\
<50\end{array}$ & $\begin{array}{r}-- \\
-- \\
-- \\
-- \\
-- \\
-- \\
-- \\
-- \\
-- \\
-- \\
5 \\
4 \\
-- \\
<4 \\
-- \\
31 \\
<45 \\
<45 \\
<45 \\
<45 \\
<45 \\
<45 \\
<45\end{array}$ & $\begin{array}{r}-- \\
-- \\
10 \\
-- \\
-- \\
-- \\
-- \\
-- \\
10 \\
10 \\
<140 \\
<140 \\
<140 \\
<140 \\
<140 \\
<140 \\
<25 \\
<25 \\
<25 \\
<25 \\
<25 \\
<25 \\
<25\end{array}$ & $\begin{array}{r}-- \\
-- \\
-- \\
-- \\
-- \\
-- \\
-- \\
-- \\
-- \\
-- \\
<10 \\
150 \\
220 \\
20 \\
10 \\
40 \\
<10 \\
<10 \\
<10 \\
<10 \\
<10 \\
<10 \\
<10\end{array}$ & $\begin{array}{r}890 \\
20 \\
610 \\
130 \\
6,000 \\
<10 \\
280 \\
1,400 \\
120 \\
10 \\
200 \\
40 \\
30 \\
20 \\
10 \\
150 \\
68 \\
<10 \\
<10 \\
<10 \\
<10 \\
<10 \\
<10\end{array}$ & $\begin{array}{r}20 \\
<10 \\
20 \\
100 \\
30 \\
20 \\
40 \\
30 \\
20 \\
30 \\
<100 \\
100 \\
100 \\
<100 \\
100 \\
200 \\
<40 \\
<40 \\
<40 \\
<40 \\
<40 \\
<40 \\
<40\end{array}$ \\
\hline \multicolumn{12}{|c|}{ Centre County } \\
\hline $\begin{array}{l}238 \\
240 \\
247 \\
258 \\
251 \\
296 \\
299 \\
358 \\
372 \\
372 \\
399 \\
402 \\
403 \\
404 \\
410 \\
411 \\
414 \\
418 \\
421 \\
426 \\
438 \\
447 \\
485 \\
487 \\
494 \\
498 \\
509\end{array}$ & $\begin{array}{l}07-16-80 \\
07-16-80 \\
08-06-80 \\
10-08-80 \\
10-22-80 \\
10-21-80 \\
06-18-85 \\
10-23-80 \\
11-05-80 \\
06-26-85 \\
06-27-85 \\
06-10-85 \\
06-10-85 \\
06-12-85 \\
06-12-85 \\
06-12-85 \\
06-20-85 \\
06-20-85 \\
06-19-85 \\
06-19-85 \\
06-12-85 \\
06-20-85 \\
06-27-85 \\
06-25-85 \\
06-27-85 \\
06-27-85 \\
06-25-85\end{array}$ & $\begin{array}{l}\text { Os } \\
\text { Os } \\
\text { Obl } \\
\text { On } \\
\text { Obf } \\
\text { Obf } \\
\text { Oa } \\
\text { Obf } \\
\text { Ocn } \\
\text { Ocn } \\
\text { Ocn } \\
\text { Cgm } \\
\text { Os } \\
C_{g 1} \\
C_{81} \\
C_{81} \\
\text { Oa } \\
\text { Obf } \\
\text { Os } \\
\text { Obf } \\
\text { On } \\
\text { Obf } \\
\text { Obl } \\
\text { Obl } \\
\text { Obf } \\
\text { Ocn } \\
\text { Obl }\end{array}$ & $\begin{array}{r}r- \\
<10 \\
-- \\
<5 \\
-- \\
<500 \\
-- \\
<5 \\
<500 \\
<500 \\
<500 \\
<500 \\
<500 \\
<500 \\
\quad 9 \\
<500 \\
<500 \\
<500 \\
<500 \\
<500 \\
<500 \\
<500 \\
<500 \\
<500 \\
<500 \\
<500\end{array}$ & $\begin{array}{l}-- \\
-- \\
-- \\
-- \\
-- \\
-- \\
53 \\
-- \\
-- \\
33 \\
81 \\
22 \\
16 \\
23 \\
65 \\
63 \\
47 \\
53 \\
12 \\
67 \\
30 \\
26 \\
51 \\
90 \\
83 \\
89 \\
45\end{array}$ & $\begin{array}{r}-- \\
<3 \\
<1 \\
<1 \\
<1 \\
<10 \\
<1 \\
<1 \\
<10 \\
<10 \\
<10 \\
<10 \\
<10 \\
10 \\
3 \\
<10 \\
<10 \\
<10 \\
<10 \\
<10 \\
<10 \\
<10 \\
<10 \\
<10 \\
10 \\
<10\end{array}$ & $\begin{array}{l}\quad-- \\
10 \\
-- \\
<10 \\
550 \\
-- \\
<10 \\
<50 \\
<50 \\
<50 \\
<50 \\
<50 \\
<50 \\
<50 \\
<50 \\
<50 \\
<50 \\
<50 \\
<50 \\
<50 \\
<50 \\
<50 \\
<50 \\
<50 \\
<50\end{array}$ & $\begin{array}{r}-- \\
-- \\
<50 \\
-- \\
<5 \\
-- \\
<45 \\
-- \\
<5 \\
<45 \\
<45 \\
<45 \\
<45 \\
<45 \\
<45 \\
17 \\
<45 \\
<45 \\
<45 \\
<45 \\
<45 \\
<45 \\
<45 \\
<45 \\
<45 \\
<45 \\
<45\end{array}$ & $\begin{array}{r}-- \\
-- \\
<10 \\
--- \\
20 \\
20 \\
<25 \\
-- \\
10 \\
<25 \\
<25 \\
<25 \\
<25 \\
<25 \\
<25 \\
43 \\
<25 \\
<25 \\
<25 \\
<25 \\
<25 \\
<25 \\
<25 \\
<24 \\
<25 \\
<25 \\
<25\end{array}$ & $\begin{array}{r}r- \\
-- \\
-- \\
-- \\
-- \\
-- \\
<10 \\
-- \\
-- \\
170 \\
480 \\
<10 \\
<10 \\
<10 \\
<10 \\
<10 \\
<10 \\
<10 \\
<10 \\
<10 \\
<10 \\
<10 \\
220 \\
320 \\
440 \\
490 \\
290\end{array}$ & $\begin{array}{r}15 \\
30 \\
30 \\
<10 \\
10 \\
140 \\
<10 \\
30 \\
90 \\
40 \\
<10 \\
<10 \\
<10 \\
<10 \\
<10 \\
24 \\
<10 \\
<10 \\
<10 \\
<10 \\
<10 \\
<10 \\
<10 \\
<10 \\
<10 \\
<10 \\
<10 \\
<10\end{array}$ & $\begin{array}{r}10 \\
10 \\
60 \\
60 \\
80 \\
-- \\
<40 \\
80 \\
90 \\
<40 \\
<40 \\
<40 \\
<40 \\
<40 \\
<40 \\
<40 \\
<40 \\
<40 \\
<40 \\
<40 \\
<40 \\
<40 \\
<40 \\
<40 \\
<40 \\
<40 \\
<40\end{array}$ \\
\hline
\end{tabular}


Table 10.--Chemical analyses of trace metals in well and spring water--Continued $[\mu \mathrm{g} / \mathrm{L}$, micrograms per liter; <, less than; --, no data]

\begin{tabular}{|c|c|c|c|c|c|c|c|c|c|c|c|}
\hline $\begin{array}{l}\text { County } \\
\text { well or } \\
\text { spring } \\
\text { number }\end{array}$ & Date & $\begin{array}{c}\text { Geologic } \\
\text { unit }\end{array}$ & $\begin{array}{l}\text { Arsentc, } \\
\text { dis - } \\
\text { solved } \\
\text { ( } \mu 8 / L \\
\text { as As) }\end{array}$ & $\begin{array}{l}\text { Barium, } \\
\text { dis- } \\
\text { solved } \\
(\mu 8 / L \\
\text { as } B a)\end{array}$ & $\begin{array}{c}\text { Cadmium, } \\
\text { dis - } \\
\text { solved } \\
\text { ( } \mu g / L \\
\text { as Cd) }\end{array}$ & $\begin{array}{l}\text { Chro- } \\
\text { mium, } \\
\text { dis- } \\
\text { solved } \\
(\mu 8 / L \\
\text { as Cr) }\end{array}$ & $\begin{array}{l}\text { Lead, } \\
\text { dis- } \\
\text { solved } \\
(\mu g / L \\
\text { as } \mathrm{Pb})\end{array}$ & $\begin{array}{l}\text { Nickel, } \\
\text { dis- } \\
\text { solved } \\
(\mu \mathrm{g} / \mathrm{L} \\
\text { as Ni) }\end{array}$ & $\begin{array}{l}\text { Stron- } \\
\text { tium, } \\
\text { dis- } \\
\text { solved } \\
\text { ( } \mu \text { g/L } \\
\text { as Sr) }\end{array}$ & $\begin{array}{l}\text { Zinc, } \\
\text { dis- } \\
\text { solved } \\
(\mu g / L \\
\text { as } \mathrm{Zn})\end{array}$ & $\begin{array}{l}\text { Alumi- } \\
\text { num, } \\
\text { dis- } \\
\text { solved } \\
\text { ( } \mu \text { g/L } \\
\text { as } A I)\end{array}$ \\
\hline
\end{tabular}

$\begin{array}{ll} & \\ 512 & 06-26-85 \\ 518 & 06-26-85 \\ 536 & 06-17-85 \\ 544 & 06-17-85 \\ 546 & 07-11-85 \\ 555 & 06-24-85 \\ 589 & 06-18-85 \\ 603 & 06-26-85 \\ 609 & 06-18-85 \\ 623 & 06-26-85 \\ 632 & 06-25-85 \\ 640 & 06-18-85 \\ \text { SP4 } & 08-08-85 \\ \text { SP11 } & 08-13-85 \\ \text { SP14 } & 08-07-85 \\ \text { SP17 } & 08-08-85 \\ \text { SP18 } & 08-15-85 \\ \text { SP19 } & 08-08-85 \\ \text { SP23 } & 08-14-85 \\ \text { SP24 } & 08-15-85 \\ \text { SP25 } & 08-14-85 \\ \text { SP32 } & 08-07-85 \\ & \end{array}$

\section{Centre County--Continued}

$\begin{array}{lr}\text { Obl } & <500 \\ \text { Ocn } & <500 \\ \text { Obf } & <500 \\ \text { On } & <500 \\ \text { Oba } & <500 \\ \text { On } & <500 \\ \text { Obf } & <500 \\ \text { Ob1 } & <500 \\ C_{8} & <500 \\ \text { Ocn } & <500 \\ C_{8} & <500 \\ \text { Obf } & <500 \\ \text { Ob1 } & <1,000 \\ \text { Ob1 } & <1,000 \\ \text { Cg } & <1,000 \\ \text { On } & <1,000 \\ C g m & <1,000 \\ \text { On } & <1,000 \\ \text { Ob1 } & <1,000 \\ \text { Obl } & <1,000 \\ \text { Ocn } & <1,000 \\ \text { Ocn } & <1,000\end{array}$

30
310
45
49
32
41
66
54
20
16
14
33
38
48
42
32
22
23
37
36
32
39

$<10$
$<10$
$<10$
$<10$
$<10$
$<10$
$<10$
$<10$
$<10$
$<10$
$<10$
$<10$
$<10$
$<10$
$<10$
$<10$
$<10$
$<10$
$<10$
$<10$
$<10$
$<10$

$\begin{array}{ll}<50 & <45 \\ <50 & <45 \\ <50 & <45 \\ <50 & <45 \\ <50 & <45 \\ <50 & <45 \\ <50 & <45 \\ <50 & <45 \\ <50 & <45 \\ <50 & <45 \\ <50 & <45 \\ <50 & <45 \\ <50 & <45 \\ <50 & <45 \\ <50 & <45 \\ <50 & <45 \\ <50 & <45 \\ <50 & <45 \\ <50 & <45 \\ <50 & <45 \\ <50 & <45 \\ <50 & <45\end{array}$

$<25$
$<25$
$<25$
$<25$
$<25$
$<25$
$<25$
$<25$
$<25$
$<25$
$<25$
$<25$
$<25$
$<25$
$<25$
$<25$
$<25$
$<25$
$<25$
$<25$
$<25$
$<25$

150
2,500
$<10$
$<10$
$<10$
25
$<10$
120
$<10$
140
$<10$
$<10$
41
210
38
31
$<10$
$<10$
230
860
110
87

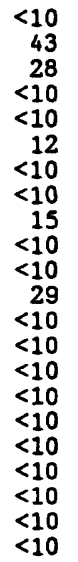

$<40$
$<40$
$<40$
$<40$
$<40$
$<40$
$<40$
210
$<40$
$<40$
$<40$
$<40$
650
$<40$
$<40$
$<40$
$<40$
$<40$
$<40$
$<40$
$<40$
$<40$

\section{Clinton County}

$\begin{array}{ll}156 & 06-09-81 \\ 157 & 06-08-81 \\ 159 & 06-08-81 \\ 162 & 06-09-81 \\ 167 & 06-07-81 \\ 169 & 06-09-81 \\ 172 & 06-10-81 \\ 277 & 06-16-81 \\ 283 & 06-17-81 \\ 284 & 06-17-81 \\ 285 & 06-17-81 \\ 297 & 06-23-81 \\ 298 & 06-23-81 \\ 353 & 06-25-85 \\ 354 & 06-25-85 \\ 359 & 06-25-85 \\ 375 & 06-24-85 \\ 376 & 06-25-85 \\ \text { SP2 } & 08-13-85 \\ \text { SP12 } & 08-12-85 \\ \text { SP17 } & 08-14-85 \\ \text { SP21 } & 08-14-85 \\ & \end{array}$

$\begin{array}{lrr}\text { Obf } & <1 & - \\ \text { Obl } & <1 & - \\ \text { Obl } & <1 & - \\ \text { Obf } & <1 & - \\ \text { Obf } & <1 & - \\ \text { Obf } & <1 & - \\ \text { Ocn } & <1 & - \\ \text { Ob1 } & <1 & - \\ \text { Ocn } & <1 & - \\ \text { Ocn } & <1 & - \\ \text { Obf } & <1 & - \\ \text { Ocn } & <1 & - \\ \text { Ob1 } & <1 & - \\ \text { Ob1 } & <500 & 27 \\ \text { Obf } & <500 & 7 \\ \text { Obf } & <500 & 4 \\ \text { Obf } & <500 & 60 \\ \text { Oa } & <500 & 2 \\ \text { Obf } & <1,000 & 3 \\ C p h & <1,000 & 27 \\ C p h & <1,000 & 31 \\ \text { Ob1 } & <1,000 & 35\end{array}$

$\begin{array}{lll}-- & <1 & <1 \\ -- & <1 & <1 \\ -- & <1 & <1 \\ -- & <1 & <1 \\ -- & <1 & <1 \\ -- & <1 & <1 \\ -- & <1 & <1 \\ -- & <1 & <1 \\ -- & <1 & <1 \\ -- & <1 & <1 \\ -- & <1 & <1 \\ -- & <1 & <1 \\ 27 & <10 & <50 \\ 78 & <10 & <50 \\ 49 & <10 & <50 \\ 60 & <10 & <50 \\ 26 & <10 & <50 \\ 38 & <10 & <50 \\ 27 & <10 & <50 \\ 31 & <10 & <50 \\ 35 & <10 & <50\end{array}$

$<1$
$<1$
$<1$
$<1$
$<1$
$<1$
$<1$
$<1$
$<1$
$<1$
$<1$
$<1$
$<1$
$<45$
$<45$
$<45$
$<9$
$<45$
$<45$
$<45$
$<<5$
$<45$

$<1$
$<1$
$<1$
$<1$
$<1$
$<1$
$<1$
$<1$
$<1$
$<1$
$<1$
$<1$
$<1$
$<25$
$<25$
$<25$
$<25$
$<25$
$<25$
$<25$
$<25$
$<25$

$\begin{array}{rr}-- & <1 \\ -- & <1 \\ -- & <1 \\ -- & <1 \\ -- & <1 \\ -- & <1 \\ -- & <1 \\ -- & <1 \\ -- & <1 \\ - & <1 \\ - & <1 \\ -- & <1 \\ <10 & <10 \\ 110 & <10 \\ 100 & <10 \\ 12 & 24 \\ <10 & 340 \\ 110 & <10 \\ <10 & <10 \\ 140 & <10 \\ 170 & <10\end{array}$

$<1$
$<1$
$<1$
$<1$
$<1$
$<1$
$<1$
$<1$
$<1$
$<1$
$<1$
$<1$
$<1$
$<40$
$<40$
$<40$
$<40$
$<40$
$<40$
$<40$
$<40$
$<40$

\section{Buntingdon County}

$\begin{array}{lrlrr}119 & 06-05-80 & \text { On } & -- & - \\ 200 & 07-15-80 & \text { Os } & -- & - \\ 263 & 07-16-80 & \text { Oc1 } & -- & - \\ 275 & 06-17-85 & \text { Os } & <500 & 21 \\ 350 & 06-19-85 & \text { C81 } & <500 & 1 \\ 357 & 06-19-85 & \text { On } & <500 & 15 \\ 394 & 06-11-85 & \text { Oba } & <500 & 19 \\ \text { SP1 } & 08-06-85 & \text { Obf } & <1,000 & 57 \\ \text { SP2 } & 08-09-85 & \text { On } & <1,000 & \\ \text { SP13 } & 08-09-85 & \text { Ob1 } & <1,000 & 39\end{array}$

$\begin{array}{llll}-- & -- & -- & \\ -- & -- & -- & \\ -- & -- & -- & \\ 21 & <10 & <50 & <45 \\ 16 & <10 & <50 & <45 \\ 15 & <10 & <50 & <45 \\ 19 & <10 & <50 & <4 \\ 57 & <10 & <50 & < \\ 19 & <10 & <50 & <4 \\ 39 & <10 & \\ & \end{array}$

$\begin{array}{rrrrr}-- & 20 & -- & 100 & 50 \\ -- & -- & -- & 450 & 40 \\ -- & -- & -- & 10 & 70 \\ <45 & <25 & <10 & <10 & <40 \\ <45 & <25 & <10 & 390 & <40 \\ <45 & <25 & <10 & <10 & <40 \\ <45 & <25 & <10 & 240 & <40 \\ <45 & <25 & 11 & <10 & <40 \\ <45 & <25 & <10 & <10 & <40 \\ <45 & <25 & 48 & <10 & 40\end{array}$

\begin{tabular}{|c|c|c|c|c|c|c|c|c|c|c|c|}
\hline $\begin{array}{l}241 \\
273 \\
275 \\
329 \\
\text { SP2 } \\
\text { SP3 }\end{array}$ & $\begin{array}{l}07-23-80 \\
07-16-84 \\
07-30-80 \\
07-23-84 \\
08-22-85 \\
08-22-85\end{array}$ & $\begin{array}{l}\text { Obf } \\
\text { Obf } \\
\text { Obf } \\
\text { Obl } \\
\text { Oa } \\
\text { Ocn }\end{array}$ & $\begin{array}{r}-- \\
<4 \\
-- \\
<4 \\
<1,000 \\
<1,000\end{array}$ & $\begin{array}{r}-- \\
70 \\
-- \\
<60 \\
45 \\
33\end{array}$ & $\begin{array}{l}<- \\
<-\overline{-} \\
<10 \\
<10 \\
<10\end{array}$ & $\begin{array}{r}20 \\
<70 \\
110 \\
<70 \\
<50 \\
<50\end{array}$ & $\begin{array}{r}-- \\
<4 \\
-- \\
8 \\
<45 \\
<45\end{array}$ & $\begin{array}{r}r- \\
<140 \\
<-- \\
<140 \\
<25 \\
<25\end{array}$ & $\begin{array}{l}-- \\
130 \\
-- \\
280 \\
<10 \\
<10\end{array}$ & $\begin{array}{r}10 \\
80 \\
30 \\
20 \\
<10 \\
<10\end{array}$ & $\begin{array}{r}<10 \\
<100 \\
50 \\
2,500 \\
<40 \\
180\end{array}$ \\
\hline
\end{tabular}

1 Och: Coburn, Salona, and Nealmont Formations; Obl: Benner, Snyder, Hatter, and Loysburg Formations; Ocl: Coburn through Loysburg Formations; Obf: Bellefonte Formation; Oa: Axemann Formation; Oba: Bellefonte and Axemann Formations; On: Nittany Formation; Ons: Nittany and Larke Formations; Os: Stonehenge Formation; Cg: Gatesburg Formation; Cgm: Mines Member of Gatesburg Formation; Cgl: lower members of Gatesburg Formation; Cw: Warrior Formation; Cph: Pleasant Bill Formation. 


\section{Herbicides}

Ground-water samples were analyzed for organic compounds that are commonly used to control weeds in crop areas of these valleys. These compounds are in a group of related organic chemicals generally called herbicides. They include propazine, simazine, metolachlor, toxaphene, atrazine, alachlor, and cyanazine. All of these chemicals were designed to be biodegradable in the environment, to prevent harm to lifeforms other than the pests to be controlled, and to avoid contamination of water resources.

The laboratory results from 10 wells and from 10 of the larger springs are reported in table 11 . All of the samples were collected during the summer after the pesticides were applied and residues conceivably could have percolated into the ground water. Only simazine, atrazine, and alachlor were found in samples. No standards for drinking water have been established by the USEPA for these pesticides, but it is worthwhile to report their common occurrence in ground water. Four of the wells sampled contained simazine, five contained atrazine, and three contained alachlor. Water from two springs contained atrazine but no other herbicide. The exceptionally elevated concentrations of atrazine $(11 \mu \mathrm{g} / \mathrm{L})$ and alachlor $(20 \mu \mathrm{g} / \mathrm{L})$ in water from well Ba 437 probably came from a nearby point source where unused mixtures of fertilizer and pesticides were disposed of improperly. Nitrates in water from this well also were exceptionally high (100 $\mathrm{mg} / \mathrm{L}$ as $\mathrm{N}$ ).

Table 11.--Chemical analyses of pesticides in well and spring water $[\mu \mathrm{g} / \mathrm{L}$, micrograms per liter; <, less than]

\begin{tabular}{|c|c|c|c|c|c|c|c|c|c|}
\hline $\begin{array}{l}\text { County } \\
\text { well or } \\
\text { spring } \\
\text { number }\end{array}$ & Date & $\begin{array}{l}\text { Geologic } \\
\text { unit }\end{array}$ & $\begin{array}{l}\text { Propazine, } \\
\text { total } \\
(\mu g / L)\end{array}$ & $\begin{array}{l}\text { Simazine, } \\
\text { total } \\
(\mu \mathrm{L} / \mathrm{L})\end{array}$ & $\begin{array}{l}\text { Metachlor } \\
\text { in whole } \\
\text { water } \\
(\mu \mathrm{L} / \mathrm{L})\end{array}$ & $\begin{array}{l}\text { Toxaphene, } \\
\text { cota1 } \\
(\mu g / L)\end{array}$ & $\begin{array}{l}\text { Atrazine, } \\
\text { total } \\
(\mu g / L)\end{array}$ & $\begin{array}{l}\text { Alachlor. } \\
\text { total } \\
\text { recover } \\
(\mu g / L)\end{array}$ & $\begin{array}{l}\text { Cyanazine, } \\
\text { total } \\
(\mu \mathrm{L} / \mathrm{L})\end{array}$ \\
\hline \multicolumn{10}{|c|}{ Bedford County } \\
\hline $\begin{array}{l}502 \\
508 \\
629 \\
633 \\
\text { SP26 } \\
\text { SP27 }\end{array}$ & $\begin{array}{l}08-14-84 \\
08-13-84 \\
08-14-84 \\
08-23-84 \\
07-31-85 \\
08-01-85\end{array}$ & $\begin{array}{l}\text { Obf } \\
\text { On1 } \\
\text { On1 } \\
\mathrm{Cg}_{8} \\
\text { On1 } \\
\mathrm{Cg}_{8}\end{array}$ & $\begin{array}{l}<0.2 \\
<.2 \\
<.2 \\
<.2 \\
<.2 \\
<.2\end{array}$ & $\begin{array}{r}0.18 \\
.37 \\
.22 \\
<.2 \\
<.2 \\
<.2\end{array}$ & $\begin{array}{l}<0.1 \\
<.1 \\
<.1 \\
<.1 \\
<.1 \\
<.1\end{array}$ & $\begin{array}{l}<1 \\
<1 \\
<1 \\
<1 \\
<1 \\
<1\end{array}$ & $\begin{array}{l}0.14 \\
<.2 \\
.21 \\
<.2 \\
<.2 \\
<.2\end{array}$ & $\begin{array}{l}<0.05 \\
<.05 \\
<.05 \\
.08 \\
<.05 \\
<.05\end{array}$ & $\begin{array}{l}<0.2 \\
<.2 \\
<.2 \\
<.2 \\
<.2 \\
<.2\end{array}$ \\
\hline \multicolumn{10}{|c|}{ Blair County } \\
\hline $\begin{array}{l}394 \\
437 \\
459\end{array}$ & $\begin{array}{l}07-21-84 \\
08-22-84 \\
08-22-84\end{array}$ & $\begin{array}{l}\text { Oba } \\
\text { Oba } \\
\text { Ocl }\end{array}$ & $\begin{array}{l}<.2 \\
<.2 \\
<.2\end{array}$ & $\begin{array}{l}<.2 \\
<.2 \\
<.2\end{array}$ & $\begin{array}{l}<.1 \\
<.1 \\
<.1\end{array}$ & $\begin{array}{l}<1 \\
<1 \\
<1\end{array}$ & $\begin{array}{r}11 \\
.3\end{array}$ & $\begin{array}{l}<.05 \\
20.0 \\
<.05\end{array}$ & $\begin{array}{l}<.2 \\
<.2 \\
<.2\end{array}$ \\
\hline \multicolumn{10}{|c|}{ Centre County } \\
\hline $\begin{array}{l}\text { SP17 } \\
\text { SP24 } \\
\text { SP25 } \\
\text { SP32 }\end{array}$ & $\begin{array}{l}08-08-85 \\
08-15-85 \\
08-14-85 \\
08-07-85\end{array}$ & $\begin{array}{l}\text { Ons } \\
\text { Obl } \\
\text { Ocn } \\
\text { Ocn }\end{array}$ & $\begin{array}{l}<.2 \\
<.2 \\
<.2 \\
<.2\end{array}$ & $\begin{array}{l}<.2 \\
<.2 \\
<.2 \\
<.2\end{array}$ & $\begin{array}{l}<.1 \\
<.1 \\
<.1 \\
<.1\end{array}$ & $\begin{array}{l}<1 \\
<1 \\
<1 \\
<1\end{array}$ & $\begin{array}{l}.3 \\
.11 \\
<.2 \\
.11\end{array}$ & $\begin{array}{l}.05 \\
<.05 \\
<.05 \\
<.05\end{array}$ & $\begin{array}{l}<.2 \\
<.2 \\
<.2 \\
<.2\end{array}$ \\
\hline \multicolumn{10}{|c|}{ Clinton County } \\
\hline $\begin{array}{l}\text { SP2 } \\
\text { SP12 }\end{array}$ & $\begin{array}{l}08-13-85 \\
08-12-85\end{array}$ & $\begin{array}{l}\text { Oa-Obf } \\
\text { Cph }\end{array}$ & $\begin{array}{l}<.2 \\
<.2\end{array}$ & $\begin{array}{l}<.2 \\
<.2\end{array}$ & $\begin{array}{l}<.1 \\
<.1\end{array}$ & $\begin{array}{l}<1 \\
<1\end{array}$ & $\begin{array}{l}<.2 \\
<.2\end{array}$ & $\begin{array}{l}<.05 \\
<.05\end{array}$ & $\begin{array}{l}<.2 \\
<.2\end{array}$ \\
\hline \multicolumn{10}{|c|}{ Mifflin County } \\
\hline $\begin{array}{l}339 \\
362 \\
389 \\
\text { SP2 } \\
\text { SP3 }\end{array}$ & $\begin{array}{l}07-23-84 \\
07-17-84 \\
07-18-84 \\
08-22-85 \\
08-22-85\end{array}$ & $\begin{array}{l}\text { Obf } \\
\text { Obl } 1 \\
\text { Obf } \\
O a \\
O b 1\end{array}$ & $\begin{array}{l}<.2 \\
<.2 \\
<.2 \\
<.2 \\
<.2\end{array}$ & $\begin{array}{l}<.2 \\
<.32 \\
<.2 \\
<.2 \\
<.2\end{array}$ & $\begin{array}{l}<.1 \\
<.1 \\
<.1 \\
<.1 \\
<.1\end{array}$ & $\begin{array}{l}<1 \\
<1 \\
<1 \\
<1 \\
<1\end{array}$ & $\begin{array}{l}<.2 \\
.28 \\
<.2 \\
.1 \\
<.2\end{array}$ & $\begin{array}{l}<.05 \\
<.05 \\
<.05 \\
<.05 \\
<.05\end{array}$ & $\begin{array}{l}<.2 \\
<.2 \\
<.2 \\
<.2 \\
<.2\end{array}$ \\
\hline
\end{tabular}

1 Ocn: Coburn, Salona, and Nealmont Formations; Obl: Benner, Snyder, Hatter, and Loysburg Formations; Oc1: Coburn through Loysburg Formations; Obf: Bellefonte Formation; Oa: Axemann Formation; Oba: Bellefonte and Axemann Formations; Ons: Nittany and Larke Formations; Os: Stonehenge Formation; C 8 : Gatesburg Formation; Cph: Pleasant Hill Formation. 


\section{Problems Related to Ground-Water Quality}

Although the quality of ground water in all the valleys is generally suitable for most uses, the data indicate some problems are developing and problems that currently are confined to local areas could become more widespread. These are problems related to the activities of man in contrast to the scattered individual problems caused by natural processes on native minerals or distribution-system materials.

The greatest concern is the increasing nitrate concentrations in ground water. Most of the nitrate is derived from manure and artificial fertilizers applied to agricultural lands. Small amounts also come from both natural sources and septic-tank effluent. The median nitrate concentration in well water from carbonate rocks of Centre County, based on 19 analyses prior to 1971 , is $2.1 \mathrm{mg} / \mathrm{L}$ (Wood, 1980, table 7). The median for 63 analyses used in this study from the same area is twice that of the earlier results, or 4.2 $\mathrm{mg} / \mathrm{L}$.

Nitrate exceeded $10 \mathrm{mg} / \mathrm{L}$ in 10 percent of the residential wells of the Nittany Valley in 1967 (Langmuir, 1971), and in 13 percent of well water analyses from the Nittany Valley used in this study. The finding of at least one herbicide in 11 of the 20 samples that were analyzed for herbicides supports an agricultural source for the nitrate problem. Both are spread widely, often simultaneously, over the cropland. The data show a trend of increasing nitrate contamination in ground water, through time, that clearly is related to agricultural practices.

A common local problem is the leakage of petroleum products into the carbonate aquifer. At least nine sites where petroleum or other organic contaminants were detected were being monitored or were undergoing clean-up during the 2 years that data were being collected for this study.

Ground-water is contaminated at several waste storage or disposal sites or is believed to be in danger of being contaminated from current or proposed future storage and disposal sites in the valleys. These include liquid waste lagoons and landfills.

Elevated concentrations of iron and manganese are sufficiently common in ground water to warrant mention. Pyritic minerals in the rocks are the likely natural source of these metals. Iron and manganese may become more prominent if acid contaminants or acid rain increase the rate these metals are leached from soil horizons. 


\section{CONCLUSIONS}

Large supplies of good quality ground water are available in the 10 anticlinal valleys of central Pennsylvania that are floored by Cambrian and Ordovician carbonate rocks. The total annual withdrawals of water from all valleys is about $43 \mathrm{Mgal} / \mathrm{d}$. Ground water supplies about $38 \mathrm{Mgal} / \mathrm{d}$ of this amount; consumptive use is estimated to be $8 \mathrm{Mgal} / \mathrm{d}$. Current development of these water resources has tapped only a small part of the available supply in most valleys. However, pumpage of $8.1 \mathrm{Mgal} / \mathrm{d}$ in the vicinity of State College could lower water levels significantly in the area; accordingly, monitoring of water levels in that area would be prudent.

The carbonate-rock units form a heterogeneous aquifer system in each of the valleys. Heterogeneity in the yielding characteristics of the aquifer system is chiefly a function of lithologic variability. Differences in lithology directly affect the rate of solution of the carbonate rock mass. Insoluble clay, silt, and sand materials in the carbonate rocks inhibit solution, reducing the size and number of openings formed to store and transmit water. Indirectly, lithology has modified the response of the carbonate rocks to stress resulting in differences in the number, distribution, and size of fracture and bedding openings. These openings provide the network in which caves and water-bearing conduits develop. Fracture traces, visible on aerial photographs, that are oriented parallel to local cave passages can help in the selection of sites for high-production-use we11s.

Large differences exist within and between the several carbonate rock units in their ability to yield water to wells. The median 1-hour specific capacities of wells, in $[(\mathrm{gal} / \mathrm{min}) / \mathrm{ft}]$, range from 0.08 (Coburn through Nealmont Formations, undivided) to 0.93 (Axemann Formation) for low-production uses and from 0.12 (Coburn through Nealmont Formations, undivided) to 33 (Nittany Formation) for high-production uses.

An ideally located well is capable of producing about $1,000 \mathrm{gal} / \mathrm{min}$ from the Gatesburg and Nittany Formations; at least $500 \mathrm{gal} / \mathrm{min}$ from the Bellefonte and Axemann Formations; at least $100 \mathrm{gal} / \mathrm{min}$ from the undivided Benner through Loysburg, undivided Coburn through Loysburg, undivided Bellefonte and Axemann, undivided Nittany and Larke, Stonehenge and Warrior Formations; and $50 \mathrm{gal} / \mathrm{min}$ or more from the undivided Coburn through Nealmont, and Rockdale Run and Shadygrove Formations. Wells located in valleys or on fracture traces have the greatest yield potential. Wells located on hilltops have the lowest yield potential. 
More than 40 large springs discharge water from the carbonate rocks in these valleys. Arch Spring in the Nittany Valley and Mammoth Spring in the Kishacoquillas Valley have measured discharges more than $10,000 \mathrm{gal} / \mathrm{min}$. About 60 percent of the large springs flow more than 1,000 gal/min.

Water-budgets for two ground-water basins, generally representative of the two types of geohydrologic systems in these valleys, show that the average ground-water discharge is $0.62\left[(\mathrm{Mgal} / \mathrm{d}) / \mathrm{mi}^{2}\right]$ from the Kishacoquillas basin and $0.80\left[(\mathrm{Mgal} / \mathrm{d}) / \mathrm{mi}^{2}\right]$ from the Spring Creek basin. The Spring Creek basin is representative of the westernmost valleys whose centers are underlain by the Gatesburg Formation, and the Kishacoquillas basin is representative of the other valleys. These discharges are available for consumptive use in each of the basins. However, water not returned to the basin may deplete streamflow. During drought periods, the ground-water discharge declines to 0.34 $\left[(\mathrm{Mgal} / \mathrm{d}) / \mathrm{mi}^{2}\right]$ and $0.45\left[(\mathrm{Mgal} / \mathrm{d}) / \mathrm{mi}^{2}\right]$ in the Kishacoquillas and Spring Creek basins, respectively.

The most pervasive and growing water-quality problem is the increased concentration of nitrate in ground water largely caused by agricultural practices. About 12 percent of the samples analyzed contain nitrate concentrations that exceed the USEPA's MCL of $10 \mathrm{mg} / \mathrm{L}$. Median concentrations of nitrate range from $3.3 \mathrm{mg} / \mathrm{L}$ in the Penns, Brush, Sugar, and northern Nittany Valleys to $5.9 \mathrm{mg} / \mathrm{L}$ in the Kishacoquillas Valley. The presence of biodegradable herbicides in more than half the samples analyzed is related to the nitrate problem and the widespread application of these chemicals to cropland. Locally, water-quality problems are caused by accidental spills or leaks of petroleum products and other toxic liquid contaminants. At least nine of these local problems were discovered, were being monitored, or were undergoing cleanup in the valleys during the 2 years of field study for this project.

Iron and manganese slightly exceed the USEPA's SMCL in less than 10 percent of the analyzed samples. These metals, although aesthetically undesirable, pose no health threat for potable supplies. Solution of calcium and manganesium carbonate minerals, which comprise the bulk of the rocks in these valleys, cause the water to be alkaline and hard to very hard. 
Becher, A.E., and Root, S.I., 1981, Groundwater and geology of the Cumberland Valley, Cumberland County, Pennsylvania: Pennsylvania Geological Survey, Fourth Series, Water Resource Report 50, 95 p.

Becher, A.E., and Taylor, L.E., 1982, Groundwater resources in the Cumberland and contiguous valleys of Franklin County, Pennsylvania: Pennsylvania Geological Survey, Fourth Series, Water Resource Report 53, 67 p.

Berg, T.M., and Dodge, C.M., 1981, Atlas of preliminary geologic quadrangle maps of Pennsylvania Map 61: Pennsylvania Geological Survey, Fourth Series, $636 \mathrm{p}$.

Berg, T.M., Edmunds, W.E., Geyer, A.R., and others, 1980, Geologic map of Pennsylvania: Pennsylvania Geological Survey, Fourth Series, map 1, 3 sheets, scale $1: 250,000$.

Berg, T.M., McInerney, M.K., Way, J.H., and MacLachlan, D.B., 1983, Stratigraphic correlation chart of Pennsylvania: Pennsylvania Geological Survey, Fourth Series, General Geology Report 75.

Butts, Charles, 1918, Geologic section of Blair and Huntingdon Counties, Pennsylvania, American Journal of Science, v. 46, p. 523-537.

-.-1939, Tyrone quadrangle, Pennsylvania: Pennsylvania Geological Survey, Fourth Series, Atlas 96, 118 p.

-.-1945, Hollidaysburg - Huntingdon folio, Pennsylvania: U.S. Geological Survey, Geologic Atlas, Folio 227.

Butts, Charles, and Moore, E.S., 1936, Geology and mineral resources of the Bellefonte quadrangle, Pennsylvania: U.S. Geological Survey Bulletin $855,111 \mathrm{p}$.

Carrucio, F.T., 1963, The hydrogeology of the sewage disposal experiment area northwest of State College, Pennsylvania: University Park, Pennsylvania, Pennsylvania State University, unpublished M.S. thesis, $132 \mathrm{p}$.

Clark, J.H., 1965, The geology of the Ordovician carbonate formations in the State College, Pennsylvania, area and their relationships to the general occurrence and movement of ground water: University Park, Pennsylvania, Pennsylvania State University, unpublished M.S. thesis, $114 \mathrm{p}$.

-..-1970, Geology of the carbonate rocks in western Franklin County, Pennsylvania: Pennsylvania Geological Survey, Fourth Series, Progress Report 180, 1 sheet.

Council, K.A., 1979, SAS users guide; SAS Institute, 494 p. 
Cravotta, C.A., 1986, Spatial and temporal variations of ground-water chemistry in the vicinity of carbonate-hosted zinc-lead occurrences, Sinking Valley, Blair County, Pennsylvania: University Park, Pennsylvania, Pennsylvania State University, unpublished M.S. thesis, 405 p.

Dayton, G.O., and White, W.B., 1979, The caves of Centre County, Pennsylvania: Mid-Appalachian Region of the National Speleological Society, Bulletin $11,126 \mathrm{p}$.

Dayton, G.O., White, W.B., and White, E.L., 1981, The caves of Mifflin County, Pennsylvania: Mid-Appalachian Region of the National Speleological Society, Bulletin 12, 76 p.

Deike, R.G., 1969, Relations of jointing to orientation of solution cavities in limestones in central Pennsylvania: American Journal of Science, v. 267, p. $1230-1248$.

Deines, Peter, Langmuir, Donald, and Harmon, R.S., 1974, Stable carbon isotope ratios and the existence of a gas phase in the evolution of carbonate ground waters: Geochimica et Cosmochimica Acta. v. 38, p. 1147-1164.

Drake, J.J., and Wigley, T.M.L., 1975, The effect of climate on the chemistry of carbonate groundwater: Water Resources Research, v. 11, n. 6, p. 958-962.

Durfor, C.N., and Becker, Edith, 1964, Public water supplies of the 100 largest cities in the United States, 1962, U.S. Geological Survey WaterSupply Paper 1812, 364 p.

Eby, J.R., 1975, The geology and water resources for land-use planning, of Potter Township, Centre County, Pennsylvania: University Park, Pennsylvania, Pennsylvania State University, unpublished M.S. thesis, $169 \mathrm{p}$.

Flippo, H.N., Jr., 1974, Springs of Pennsylvania: Department of Environmental Resources, Office of Resources Management, Water Resources Bulletin 10, $46 \mathrm{p}$.

Flueckinger, L.A., 1969, Geology of a portion of the Allensville quadrangle, Centre and Huntingdon Counties, Pennsylvania: Pennsylvania Geological Survey, Fourth Series, Progress Report 176, map 1, scale 1:24,000.

Geyer, A.R., and Wilhusen, J.P., 1982, Engineering characteristics of the rocks of Pennsylvania: Environmental Geology Report 1, 300 p.

Giddings, T.M., Jr., 1974, Hydrologic budget of Spring Creek drainage basin, Pennsylvania: University Park, Pennsylvania, Pennsylvania State University, unpublished Ph.D. thesis, $76 \mathrm{p}$. 
Heath, R.C., 1984, Basic ground-water hydrology: U.S. Geological Survey Water-Supply Paper 2220, 84 p.

Hem, J.D., 1985, Study and interpretation of the chemical characteristics of natural water: U.S. Geological Survey Water-Supply Paper 2254, 264 p.

Hunter, P.M., 1977, The environmental geology of the Pine Grove MillsStormstown area, central Pennsylvania, with emphasis on the bedrock geology and ground water resources: University Park, Pennsylvania, Pennsylvania State University, unpublished M.S. thesis, 319 p.

Jacobson, R.L., 1973, Controls on the quality of some carbonate ground waters, dissociation constants of calcite and calcium bicarbonate from zero to fifty degrees Celsius: University Park, Pennsylvania, Pennsylvania State University, unpublished $\mathrm{Ph} . \mathrm{D}$. thesis, $132 \mathrm{p}$.

Jacobson, R.L., and Langmuir, Donald, 1970, The chemical history of some spring waters in carbonate rocks: Ground Water, v. 8, no. 3, p. 5-9.

Kay, G.M., 1944, Middle Ordovician of central Pennsylvania: Journal of Geology, v. 52, p. 1-23, 97-116.

Knowles, R.R., 1966, Geology of a portion of the Everett 15-minute quadrangle, Bedford County, Pennsylvania: Pennsylvania Geological Survey, Fourth Series, Progress Report 170, 90 p.

Konikow, L.F., 1969, Mountain runoff and its relation to precipitation, groundwater, and recharge to the carbonate aquifers of Nittany Valley, Pennsylvania: University Park, Pennsylvania, Pennsylvania State University, unpublished M.S. thesis, $128 \mathrm{p}$.

Krothe, N.C., 1976, Factors controlling the water chemistry beneath a floodplain in a carbonate terrane, central Pennsylvania: University Park, Pennsylvania, Pennsylvania State University, unpublished Ph.D. thesis, $233 \mathrm{p}$.

Lamoureaux, P.E., and Powe11, W.J., 1966, Stratigraphic and structural guides to the development of water wells and well fields in a limestone terrane: International Association of Scientific Hydrology: Commission of Subterranean Waters, no. 52, p. 363-375.

Landon, R.A., 1963, The geology of the Gatesburg Formation in the Bellefonte quadrangle, Pennsylvania, and its relation to the general occurrence and movement of ground water: University Park, Pennsylvania, Pennsylvania State University, unpublished M.S. thesis, 88 p.

Langmuir, Donald, 1971, The geochemistry of some carbonate groundwaters in central Pennsylvania: Geochimica et Cosmochimica Acta., v. 35, p. 10231045 . 
Lattman, L.H., 1958, Technique of mapping geologic fracture traces and lineaments on aerial photographs: Photogrammetric Engineering, v. 24, p. $568-576$.

Lattman, L.H., and Parizek, R.R., 1964, Relationship between fracture traces and the occurrence of ground water in carbonate rocks: Journal of Hydrology, v. 2, p. 73-91.

LeGrand, H.E., and Stringfield, V.T., 1971, Water levels in carbonate rock terranes: Ground Water, v. 9, no. 3, p. 4-10.

Linsley, R.K. Jr., Kohler, M.A., and Paulhus, J.L., 1958, Hydrology for engineers: New York, McGraw-Hill Book Company, 340 p.

Lohman, S.W., 1938, Groundwater in south-central Pennsylvania: Pennsylvania Geological Survey, Fourth Series, Water Resource Report 5, 315 p.

Meiser, E.W., 1971, The geology and water resources of the BellefonteMingoville area, Pennsylvania: University Park, Pennsylvania, Pennsylvania State University, unpublished M.S. thesis, $113 \mathrm{p}$.

Meiser and Ear1/hydrogeologists, 1977, Ground-water study in the vicinity of Nease Chemical Company, State College, Pennsylvania: unpublished consultant summary report, $21 \mathrm{p}$.

Meisler, Harold, and Becher, A.E., 1971, Hydrogeology of the carbonate rocks of the Lancaster 15-minute quadrangle, southeastern Pennsylvania, Pennsylvania Geological Survey, Fourth Series, Water Resource Report 26, $149 \mathrm{p}$.

Meyer, R.R., 1963, A chart relating well diameter, specific capacity, and the coefficients of transmissibility and storage, in Bentall, Ray, compiler, Methods of determining permeability, transmissibility, and drawdown:

U.S. Geological Survey Water-Supply Paper 1536-I, p. 338-340.

Moody and Associates, Inc., 1967a, Technical report of the hydrogeological conditions in the vicinity of Martinsburg, Pennsylvania, $27 \mathrm{p}$.

-1967b, Technical report of the hydrogeological conditions in the vicinity of Williamsburg, Pennsylvania, $26 \mathrm{p}$.

-.-1970a, Hydrogeologic report on the Harter well field: 25 p.

-.-1970b, Scotia test well No. 1: Pennsylvania Game Commission, 9 p.

Mooreshead, Frank, 1975, An investigation of stream infiltration of the carbonate Nittany Valley of south-central Pennsylvania: University Park, Pennsylvania, Pennsylvania State University, unpublished M.S. thesis, $95 \mathrm{p}$. 
Parizek, R.R., and Drew, L.J., 1966, Random drilling for water in carbonate rocks: Pennsylvania State University, Mineral Industries Experiment Station Special Publication 2-65, v. 3, 22 p.

Parizek, R.R., 1976, Lineaments and groundwater: in interdisciplinary applications and interpretations of EREP data within the Susquehanna River Basin: Office for Remote Sensing of Earth Resources - Space Science and Engineering Laboratory, Pennsylvania State University, p. 4981.

Parizek, R.R., 1979, Carbonate hydrogeological environments: their relationship to land-use, Water Resources Development and Management, Final report to: Office of Water Resources Technology: Pennsylvania State University, $95 \mathrm{p}$.

Parizek, R.R., and Siddiqui, S.H., 1970, Determining the sustained yields in carbonate and fractured aquifers: Ground Water, v. 8, no. 5, 9 p.

Parizek, R.R., White, W.B., and Langmuir, Donald, 1971, Hydrogeology and geochemistry of folded and faulted carbonate rocks of the central Appalachian type and related land use problems: Geological Society of America Guidebook, 210 p.

Pelto, R.C., 1942, Petrology of the Gatesburg Formation of central Pennsylvania: University Park, Pennsylvania, Pennsylvania State University, unpublished M.S. thesis, $60 \mathrm{p}$.

Pennsylvania Department of Environmental Resources, Bureau of Resources Programming, 1979, Subbasin 12 (lower Juniata River): State Water Plan $12,127 \mathrm{p}$.

-..-1980, Subbasin 11 (upper Juniata River): State Water Plan 12, 147 p.

Pennypacker, S.P., Sopper, W.E., and Kardos, L.T., 1967, Renovation of wastewater effluent by irrigation of forest land: Journal of Water Pollution Control Federation, v. 39, no. 2, p. 285-296.

Pettyjohn, W.A., and Henning, R., 1979, Preliminary estimate of ground-water recharge rates, related streamflow and water quality in Ohio: The Ohio State University Department of Geology and Mineralogy project completion report number $552,323 \mathrm{p}$.

Pierce, K.L., 1966, Bedrock and surficial geology of the McConnellsburg quadrangle, Pennsylvania: Pennsylvania Geological Survey, Fourth Series, Atlas 109a., 111 p.

Rauch, H.W., 1972, The effects of 1ithology and other hydrologic factors on the development of solution porosity in the Middle Ordovician carbonates of central Pennsylvania: University Park, Pennsylvania, Pennsylvania State University, unpublished Ph.D. thesis, $530 \mathrm{p}$. 
Rauch, H.W., and White, W.B., 1970, Lithologic controls on the development of solution porosity in carbonate aquifers: Water Resources Research, v. 6 , no. 4, p. $1175-1192$.

Rones, Morris, 1969, A 1ithostratigraphic, petrographic, and chemical investigation of the lower Middle Ordovician carbonate rocks in central Pennsylvania: Pennsylvania Geological Survey, Fourth Series, General Geology Report 53, 224 p.

Root, S.I., 1968, Geology and mineral resources of southeastern Franklin County, Pennsylvania: Pennsylvania Geological Survey, Fourth Series, Atlas $119 \mathrm{~cd}$., $118 \mathrm{p}$.

Sando, W.J., 1957, Beekmantown Group (lower Ordovician) of Maryland: Geological Society of America Memoir 68, 143 p.

Seaber, P.R., and Hollyday, E.F., 1966, An appraisal of the ground water resources of the Juniata River basin: U.S. Geological Survey Open-File Report, $58 \mathrm{p}$.

Shuster, E.T., 1970, Seasonal variations in carbonate spring water chemistry related to ground-water flow: University Park, Pennsylvania, Pennsylvania State University, unpublished M.S. thesis, $148 \mathrm{p}$.

Shuster, E.T., and White, W.B., 1971, Seasonal fluctuations in the chemistry of limestone springs: a possible means for characterizing carbonate aquifers: Journal of Hydrology, v. 14, p. 93-128.

-.-1972, Source areas and climatic effects in carbonate groundwaters determined by saturation indices and carbon dioxide pressures: Water Resources Research, v. 8, p. 1067-1073.

Siddiqui, S.H., 1969, Hydrogeologic factors influencing well yields and aquifer hydraulic properties of folded and faulted carbonate rocks in central Pennsylvania: University Park, Pennsylvania, Pennsylvania State University, unpublished $\mathrm{Ph} . \mathrm{D}$. thesis, $502 \mathrm{p}$.

Siddiqui, S.H., and Parizek, R.R., 1971, Hydrologic factors influencing well yields in folded and faulted rocks in central Pennsylvania: Water Resource Research, v. 7, no. 5, p. 1295-1312.

-..-1972, Application of nonparametric statistical tests in hydrology: Ground Water, v. 10, no. 2, p. 1-6.

-.-1974, An application of parametric statistical tests to well-yield data from carbonates of central Pennsylvania: Journal of Hydrology, v. 21 , p. $1-14$.

Smith, R.C., 1977, Zinc and lead occurrences in Pennsylvania: Pennsylvania Geological Survey, Fourth Series, Mineral Resource Report 72, 318 p. 
Smith, R.E., 1966, Petrographic properties influencing porosity and permeability in the carbonate-quartz system as represented by the Gatesburg Formation: University Park, Pennsylvania, Pennsylvania State University, unpublished Ph.D. thesis, 196 p.

Speece, Jack, and Cullinan, Mike, 1972, The caves of Blair County, Pennsylvania: Mid-Appalachian Region of the National Speleological Society, bull. $8,90 \mathrm{p}$.

-..-1975, The caves of Huntingdon County, Pennsylvania: Mid-Appalachian Region of the National Speleological Society, bull. 9, $113 \mathrm{p}$.

Spelman, A.R., 1966, Stratigraphy of lower-Ordovician Nittany Dolomite in central Pennsylvania: Pennsylvania Geological Survey, Fourth Series, General Geology Report 47, 187 p.

Stallman, R.W., 1965, Effects of water table conditions on water level changes near pumping wells: Water Resource Research, v. 1, no. 2, p. 295-312.

State College Borough Water Authority, 1982, Hydrogeologic report Nixon well field, Gilbert Associates, W.0. 06-6769-005, 24 p.

Taylor, L.E., Werkheiser, W.E., and Kriz, M.L., 1983, Groundwater resources of the West Branch Susquehanna River basin, Pennsylvania: Pennsylvania Geological Survey, Fourth Series, Water Resource Report 56, 143 p.

Taylor, L.E., Werkheiser, W.E., duPont, N.S., and Kriz, M.L., 1982, Groundwater resources of the Juniata River basin, Pennsylvania: Pennsylvania Geological Survey, Fourth Series, Water Resource Report 54, $131 \mathrm{p}$.

Theis, C.V., 1935, The relation between the lowering of the piezometric surface and the rate and duration of discharge of a well using ground water storage: American Geophysical Union Transactions, v. 16, p. 519 525 .

-...1963, Chart for the computation of drawdowns in the vicinity of a discharging well, in Bentall, Ray, compiler, Shortcuts and special problems in aquifer tests: U.S. Geological Survey Water-Supply Paper $1545-C$, p. $10-15$.

Trainer, F.W., and Watkins, F.A., Jr., 1975, Geohydrologic reconnaissance of the upper Potomac River basin: U.S. Geological Survey Water-Supply Paper 2035,68 p.

U.S. Department of Commerce, Bureau of the Census, 1971, 1970 census of population, Pennsylvania; $33 \mathrm{p}$.

$-1981,1980$ Census of population, Number of inhabitants, Pennsylvania, series PC80-1A40. 
U.S. Department of Commerce, Environmental Data Service (published annually, 1941-1986), Climatological data, Pennsylvania.

U.S. Environmental Protection Agency, 1986a, National primary drinking water regulations: Code of Federal Regulations, Federal Register, v. 40, Part 141, July 1, 1986, p. 521-528.

-1986b, National secondary drinking water regulations: Code of Federal Regulations, Federal Register, v. 42, Part 143, July 1, 1986b, p. 587590.

U.S. Geological Survey (1961-1974, published annually), Water resource data for Pennsylvania-Part 1: Surface water records: Harrisburg,

Pennsylvania, Water Resources Division.

---(1964-1974, published annually), Water resource data for Pennsylvania, Part 2: Water quality records, Harrisburg, Pennsylvania, Water Resources Division.

--.-(1975-1985, published annual1y), Water resources data for Pennsylvania, Volume 2, Harrisburg, Pennsylvania, Water Resources Division.

Wagner, W.R., 1966, Stratigraphy of the Cambrian to Middle Ordovician rocks of central and western Pennsylvania: Pennsylvania Geological Survey, Fourth Series, General Geology Report 49, 156 p.

White, E.L., 1977, Sustained flow in small Appalachian watersheds underlain by carbonate rocks: Journal of Hydrology, v. 32, n. 1/2, p. 71-86.

Wilson, J.L., 1952, Upper Cambrian stratigraphy in the central Appalachians, Geological Society of America Bulletin, v. 63, p. 275-322.

Wood, C.R., 1980, Summary groundwater resources of Centre County, Pennsylvania: Pennsylvania Geological Survey, Fourth Series, Water Resource Report 48, 60 p. 


\section{GLOSSARY}

Anticline.--A fold in layered rocks that is convex upward.

Aquifer.--A formation, group of formations, or a part of a formation that contains sufficient saturated, permeable material to yield significant quantities of water to wells and springs.

Argillaceous.--Pertaining to rocks composed of clay or having a notable proportion of clay in their composition.

Base flow.--Discharge entering stream channels as effluent from the groundwater reservoir.

Carbonate rocks.--Rocks composed dominantly of carbonate minerals. Limestone and dolomite are the most common rocks of this type.

Calcareous.--Containing calcium carbonate.

Consumptive use.-- The quantity of water withdrawn for use that is not returned to ground-water or streamflow.

Direct runoff.--The water that moves directly over the land surface to streams promptly after rainfall or snowmelt.

Discharge, groundwater.--The process by which water is removed from the saturated zone; also the quantity of water removed.

Dolomite.--A sedimentary rock composed chiefly of the mineral dolomite, $\mathrm{CaMg}\left(\mathrm{CO}_{3}\right)_{2}$.

Drawdown.--The lowering of the water table or potentiometric surface caused by pumping.

Evapotranspiration.--Water withdrawn from a land area by direct evaporation from water surfaces and moist soil and by plant transpiration.

Fault.--A fracture or fracture zone along which there has been displacement of the two sides relative to each other. The displacement may range from a few inches to many miles.

Formation.--A fundamental unit in rock stratigraphic classification. It is a body of rock characterized by uniform rock characteristics; it is generally tabular and is mappable at the earth's surface, or traceable in the subsurface through borings.

Fracture.--A break in rocks.

Head, static. - The height above a standard datum of the surface of a column of water that can be supported by the static pressure. 


\section{GLOSSARY - - Continued}

High-production use. - Includes wells used for air conditioning, dewatering, irrigation, industry, institutions, fish hatchery, and public supply purposes.

Hydraulic gradient.--Change in static head per unit of distance in a given direction.

Limestone.--A sedimentary rock composed chiefly of the mineral calcite, $\mathrm{CaCO}_{3}$.

Low-production-use.--Includes wells used for homes, commerce, farms, and recreation purposes.

Median.--The middle value in an ordered sequence.

Perched ground water. --Ground water separated from an underlying body of ground water by a low-permeability or impermeable, unsaturated zone.

Permeability. - The capacity of a material to transmit a fluid.

Porosity.-- The ratio of the total volume of openings in a rock to the total volume of the rock, expressed as a percentage.

Potentiometric surface.--The surface that represents the static ground water head; the potentiometric surface for an unconfined aquifer is the water table.

Recharge, ground water.--The process by which water is added to the saturated zone; also the quantity of water added.

Runoff.- That part of the precipitation that appears in streams. It is the same as streamflow unaffected by artificial diversions, storage, or other works of man in or on the stream channels.

Saturated zone.--The zone in which interconnected openings are saturated with water.

Soil tonal alignments. - - The linear arrangement of similar tones or shades of color observable on aerial photographs; believed to be due to a similarity in the properties of the soil.

Specific capacity.--The yield (in gallons per minute) of a well divided by the drawdown (in feet) of water level in the well.

Specific conductance.--A measure of the capacity of water to conduct an electrical current. It varies with concentration and degree of ionization of the constituents.

Sinkhole.--A circular depression at land surface in cavernous areas underlain by carbonate bedrock. 


\section{GLOSSARY - - Continued}

Storage coefficient. - The volume of water an aquifer releases from or takes into storage per unit surface area of the aquifer per unit change in head. In an unconfined aquifer this value is about equal to specific yield.

Strike.--The direction of the line of intersection between a tilted surface (for example, a layer of rock) and a horizontal plane.

Swallow hole.--A sinkhole into which all or part of a stream disappears underground.

Stream-gaging station.--A gaging station where a record of discharge of a stream is obtained. Within the U.S. Geological Survey this term is used only for those gaging stations where a continuous record of discharge is obtained.

Surface water. - Water on the surface of the earth.

Transpiration.--The process by which vapor escapes from the living plant, principally the leaves, and enters the atmosphere.

Unconformity.--A surface of erosion that separates younger strata above older rocks.

Vadose water. - - Water in the zone of aeration above the water table.

Water table. - The upper surface of an unconfined subsurface water body where the pressure is equal to that of one atmosphere.

Water year. - The 12 -month period beginning October 1 and ending September 30 . It is designated by the calendar year in which it ends. 
Table 1.--Record of wells

Wel1 location: The number is that assigned to identify the well. It is prefixed by a two-letter abbreviation of the county. The lat-long is the coordinates, in degree and minutes, of the southeast corner of a 1 -minute quadrangle within which the well is located.

Use: C, commercial; D, dewater; H, domestic and small commercial; I, irrigation; $N$, industrial; 0 , observation; $P$, public supply; $Q$, agriculture; $R$, recreation; S, stock; $T$, institution; $U$, unused; $Z$, fish hatchery.

Topographic setting: D, depression; F, flat; H, hilltop; S, hillside; T, terrace; V, valley flat; W, upland draw; U, undulating.

Aquifer: Or: Reedsville Formation; Ocn: Coburn, Salona, and Nealmont

Formations; Ob1: Benner, Snyder, Hatter, and Loysburg Formations; Ocl:

Coburn through Loysburg Formations; Obf: Bellefonte Formation; Oa:

Axemann Formation; Oba: Bellefont and Axemann Formations; Orr:

Rockdale Run Formation; On: Nittany Formation; Onl: Nittany and Larke

Formations; Os: Stonehenge Formation; $\epsilon_{s g}$ : Shadygrove Formation; $\epsilon_{g}$ :

Gatesburg Formation; $\mathrm{Egm:} \mathrm{Mines} \mathrm{Member} \mathrm{of} \mathrm{Gatesburg} \mathrm{Formation;} \mathrm{Cgl}$ :

lower members of Gatesburg Formation; $C_{w}$ : Warrior Formation; $\epsilon_{p h}$ :

Pleasant Hill Formation; Wwb: Waynesboro Formation.

Lithology: dlmt, dolomite; lmsn, limestone; snds, sandstone; shle, shale; lmdm, limestone and dolomite; lmsh, limestone and shale.

Static water level: Date--month/last two digits of year.

Reported vield: gal/min, gallons per minute.

Specific capacity: [(gal/min)/ft], gallons per minute per foot of drawdown.

Rate: gal/min, gallons per minute.

Hardness: $\mathrm{mg} / \mathrm{L}$, milligrams per liter.

Specific conductance: $\mu \mathrm{S} / \mathrm{cm}$ at $25^{\circ} \mathrm{C}$, microsiemens per centimeter at 25 degrees Celsius. 
Table 1.--Record of wells

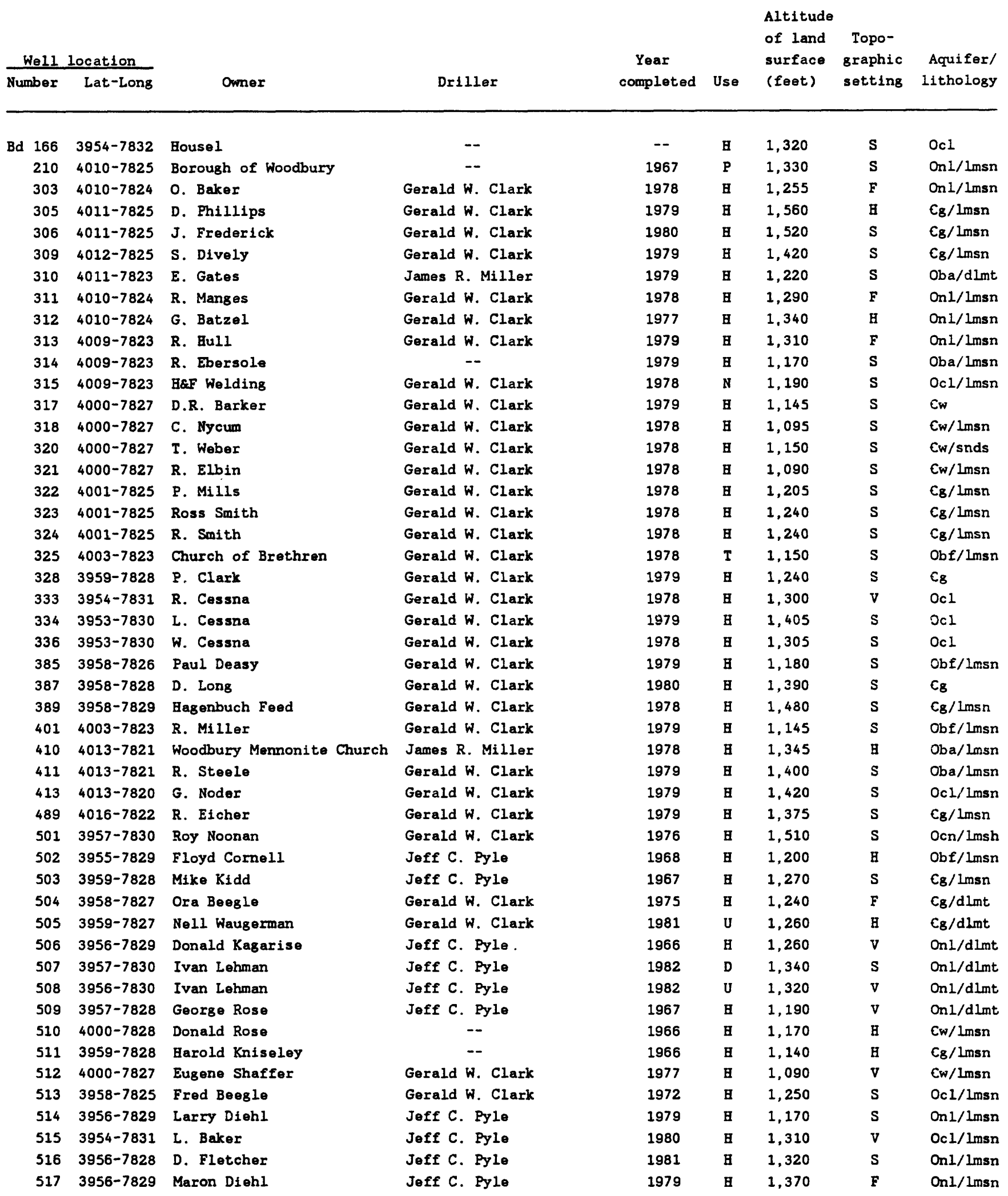


Well depth below land surface (feet)

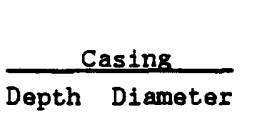

(feet) (inches)
Depths to Static water level

water-bear- Depth below Date Reported Specific

capacity/ Bar

land surface measured yield

(mo/yr) (gal/min) Rate
Specific

conduc-

(mg/L) $(\mu \mathrm{S} / \mathrm{cm})$ pH number

\begin{tabular}{|c|c|c|c|c|c|c|c|c|c|c|c|}
\hline 40 & -- & -- & -- & 27 & $10 / 84$ & 5 & -- & -- & -- & -- & 166 \\
\hline 165 & 92 & 6 & -- & 70 & $08 / 67$ & 150 & -- & 228 & -- & 7.4 & 210 \\
\hline 70 & 21 & 6 & $17 / 25 / 55$ & 10 & $08 / 80$ & 20 & $0.63 / 20$ & 171 & 265 & -- & 303 \\
\hline 441 & 256 & 6 & $355 / 430 / 436$ & 311 & $12 / 79$ & 5 & $.06 / 5$ & -- & -- & -- & 305 \\
\hline 366 & 181 & 6 & $301 / 357$ & 200 & $01 / 80$ & 30 & $.21 / 30$ & -- & -- & -- & 306 \\
\hline 366 & 47 & 6 & $260 / 320 / 335$ & 100 & $02 / 79$ & 5 & $.01 / 5$ & -- & -- & -- & 309 \\
\hline 101 & 97 & 6 & 98 & 36 & $08 / 80$ & -- & -- & 393 & 600 & -- & 310 \\
\hline 140 & 110 & 6 & $98 / 118$ & 80 & $05 / 78$ & 20 & $.66 / 20$ & -- & -- & -- & 311 \\
\hline 158 & 141 & 6 & $139 / 148$ & 75 & $11 / 77$ & 15 & $.24 / 15$ & -- & -- & -- & 312 \\
\hline 326 & 20 & 6 & $140 / 280$ & 113 & $08 / 80$ & 3 & $.02 / 3$ & 274 & 565 & -- & 313 \\
\hline 103 & 82 & 6 & 87 & 64 & $08 / 80$ & 40 & $2.0 / 40$ & 222 & 615 & -- & 314 \\
\hline 162 & 21 & 6 & -- & 35 & $08 / 80$ & 5 & -- & 274 & 600 & -- & 315 \\
\hline 182 & 141 & 6 & $139 / 169$ & 120 & $07 / 79$ & 17 & $1.00 / 17$ & 171 & 360 & 6.9 & 317 \\
\hline 325 & 107 & 6 & $200 / 265 / 304$ & 78 & $08 / 80$ & 50 & $.21 / 50$ & 103 & 265 & -- & 318 \\
\hline 182 & 164 & 6 & 163 & 70 & $08 / 78$ & 16 & $.23 / 16$ & -- & - & -- & 320 \\
\hline 182 & 21 & 6 & $60 / 176$ & 20 & $05 / 78$ & 150 & $1.1 / 150$ & -- & -- & -- & 321 \\
\hline 102 & 44 & 6 & 80 & 69 & $08 / 80$ & 8 & $.13 / 8$ & 274 & 555 & -- & 322 \\
\hline 264 & 61 & 6 & $140 / 194$ & 100 & $09 / 78$ & 6 & $.07 / 6$ & -- & -- & -- & 323 \\
\hline 571 & 21 & 6 & $115 / 184$ & 150 & $10 / 78$ & -- & $.07 / 150$ & -- & -- & -- & 324 \\
\hline 243 & 21 & 6 & $98 / 108 / 209$ & 50 & $10 / 78$ & 10 & $.07 / 10$ & -- & -- & -- & 325 \\
\hline 100 & 20 & 6 & $68 / 77$ & 40 & $10 / 79$ & 10 & $.40 / 10$ & -- & -- & -- & 328 \\
\hline 285 & 34 & 6 & $32 / 80 / 182 / 237$ & 30 & $03 / 80$ & 5 & $.04 / 5$ & 188 & 365 & -- & 333 \\
\hline 200 & 67 & 6 & 71 & 54 & $08 / 80$ & 4 & $.03 / 4$ & 171 & 365 & -- & 334 \\
\hline 202 & 61 & 6 & 191 & 39 & $08 / 80$ & 4 & $.03 / 4$ & -- & -- & -- & 336 \\
\hline 117 & 81 & 6 & 78 & 55 & $08 / 80$ & 17 & $1.3 / 17$ & 171 & 280 & -- & 385 \\
\hline 326 & 50 & 6 & $74 / 285$ & 40 & $05 / 80$ & 5 & $.02 / 5$ & -- & -- & -- & 387 \\
\hline 332 & 50 & 6 & 245 & 180 & $08 / 80$ & 15 & -- & 171 & 265 & 6.8 & 389 \\
\hline 79 & 20 & 6 & $60 / 71$ & 30 & $04 / 79$ & 12 & $.50 / 12$ & -- & -- & -- & 401 \\
\hline 150 & 136 & 6 & 136 & 117 & $08 / 80$ & 30 & -- & 274 & 420 & -- & 410 \\
\hline 346 & 20 & 6 & $90 / 109 / 244$ & 50 & $09 / 79$ & -- & $.03 / 5$ & -- & -- & -- & 411 \\
\hline 120 & 21 & 6 & $52 / 58 / 100$ & 40 & $03 / 79$ & 12 & $.30 / 12$ & -- & -- & -- & 413 \\
\hline 244 & 20 & 6 & $120 / 151$ & 116 & $09 / 80$ & 4 & $.10 / 4$ & 239 & 455 & 7.3 & 489 \\
\hline 223 & 50 & 6 & $45 / 55 / 180$ & 20 & $01 / 76$ & 5 & $.03 / 5$ & -- & -- & -- & 501 \\
\hline 120 & 25 & 6 & 60 & 26 & $08 / 83$ & 20 & -- & 188 & 540 & 7.7 & 502 \\
\hline 185 & 21 & 6 & 75 & 40 & $08 / 67$ & 2 & -- & 205 & 650 & 7.2 & 503 \\
\hline 198 & 85 & 6 & $158 / 165 / 177 / 188$ & 150 & $03 / 75$ & 18 & -- & -- & -- & -- & 504 \\
\hline 188 & 188 & 6 & 183 & 138 & $08 / 83$ & 15 & $.67 / 15$ & -- & -- & -- & 505 \\
\hline 133 & 40 & 6 & $100 / 105$ & -- & -- & 20 & -- & 188 & 450 & 7.1 & 506 \\
\hline 305 & 42 & 6 & 250 & 114 & $08 / 83$ & -- & -- & 324 & 850 & 6.9 & 507 \\
\hline 266 & -- & -- & -- & 57 & $08 / 83$ & -- & $.13 / 3$ & 393 & 830 & 7.6 & 508 \\
\hline 63 & 41 & 6 & $42 / 50$ & 15 & $11 / 67$ & -- & -- & 188 & 440 & 7.3 & 509 \\
\hline 182 & 28 & 6 & $100 / 155 / 165$ & 80 & $06 / 66$ & -- & -- & 376 & 1,000 & 7.2 & 510 \\
\hline 283 & 22 & 6 & $195 / 280$ & 95 & $04 / 66$ & 2 & -- & -- & -- & -- & 511 \\
\hline 103 & 97 & 6 & $35 / 96$ & 12 & $08 / 83$ & 20 & $.29 / 20$ & 239 & 675 & 7.4 & 512 \\
\hline 123 & 70 & 6 & 110 & -- & -- & -- & -- & 273 & 600 & 7.2 & 513 \\
\hline 105 & 42 & 6 & 75 & -- & -- & 20 & -- & -- & -- & -- & 514 \\
\hline 85 & 20 & 6 & $40 / 58$ & 16 & $09 / 83$ & 8 & -- & 256 & 660 & 7.3 & 515 \\
\hline 205 & 63 & 6 & 125 & 112 & $09 / 83$ & 3 & -- & 188 & 460 & 8.3 & 516 \\
\hline 105 & 63 & 6 & 75 & -- & -- & 15 & - & -- & -- & -- & 517 \\
\hline
\end{tabular}




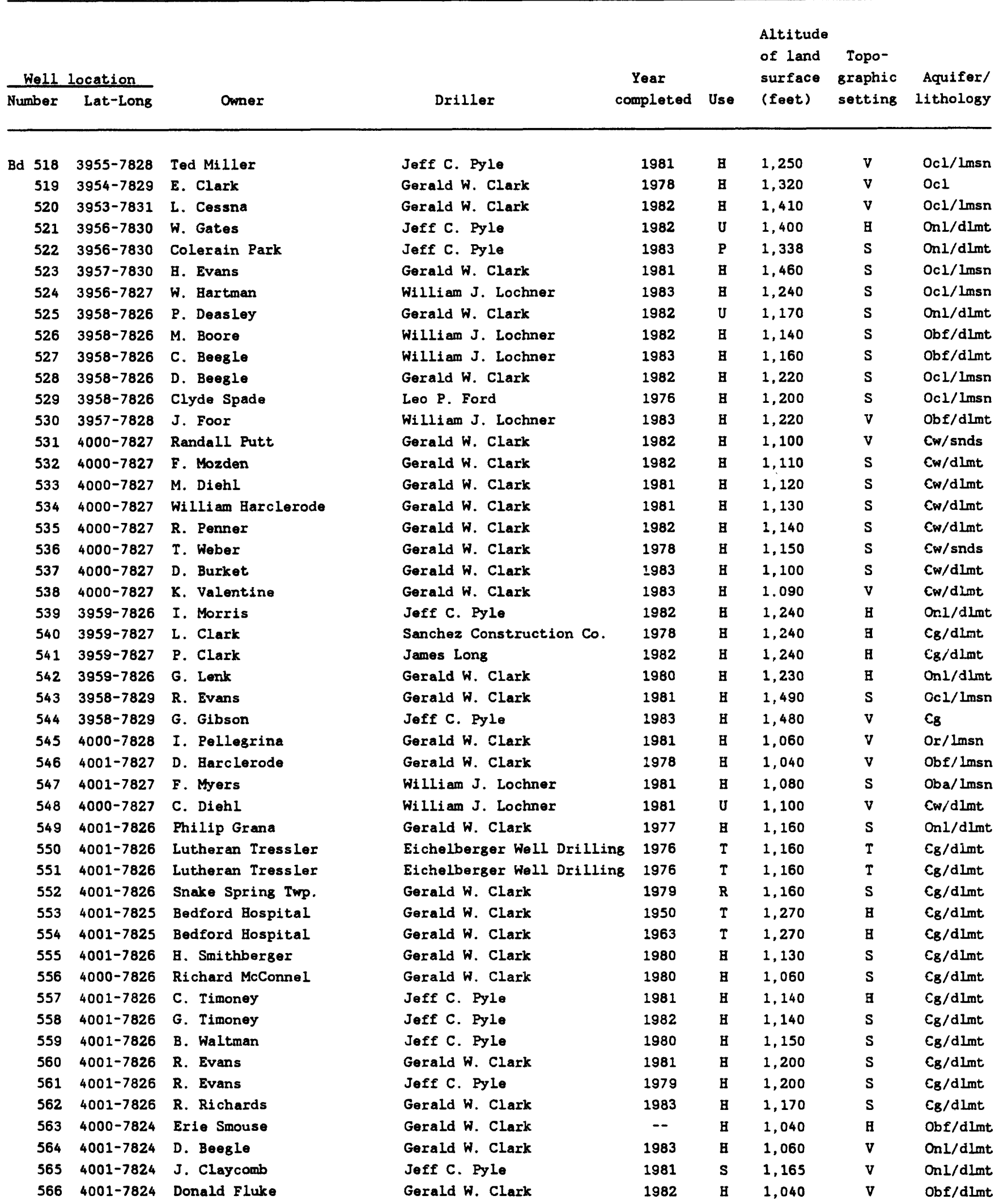




\begin{tabular}{|c|c|c|c|c|c|c|c|c|c|c|c|}
\hline \multirow{3}{*}{$\begin{array}{l}\text { Well depth } \\
\text { below land } \\
\text { surface } \\
\text { (feet) }\end{array}$} & \multirow{2}{*}{\multicolumn{2}{|c|}{ Casing }} & \multirow{3}{*}{$\begin{array}{l}\text { Depths to } \\
\text { water-bear- } \\
\text { ing zones } \\
\text { (feet) }\end{array}$} & \multicolumn{2}{|c|}{ Static water level } & \multirow{3}{*}{$\begin{array}{l}\text { Reported } \\
\text { yield } \\
(\mathrm{gal} / \mathrm{min})\end{array}$} & \multirow{3}{*}{$\begin{array}{l}\text { Specific } \\
\text { capacity/ } \\
\text { Rate }\end{array}$} & \multirow{2}{*}{\multicolumn{4}{|c|}{$\begin{array}{l}\text { Specific } \\
\text { conduc- }\end{array}$}} \\
\hline & & & & Depth below & Date & & & & & & \\
\hline & $\begin{array}{l}\text { Depth } \\
\text { (feet) }\end{array}$ & $\begin{array}{l}\text { Diameter } \\
\text { (inches) }\end{array}$ & & $\begin{array}{c}\text { land surface } \\
\text { (feet) }\end{array}$ & $\begin{array}{l}\text { measured } \\
\text { (mo/yr) }\end{array}$ & & & $\begin{array}{l}\text { Hardness } \\
\text { (mg/L) }\end{array}$ & $\begin{array}{c}\operatorname{tance} \\
(\mu \mathrm{S} / \mathrm{cm})\end{array}$ & $\mathrm{pH}$ & $\begin{array}{c}\text { Well } \\
\text { number }\end{array}$ \\
\hline
\end{tabular}

\begin{tabular}{|c|c|c|c|c|c|c|c|c|c|c|c|}
\hline 165 & 42 & -- & $70 / 150$ & 36 & $03 / 81$ & 30 & -- & -- & -- & -- & $518 \mathrm{Bd}$ \\
\hline 43 & 33 & 6 & 33 & 15 & $12 / 78$ & 20 & $0.80 / 20$ & -- & -- & -- & 519 \\
\hline 325 & 20 & 6 & 220 & 29 & $09 / 83$ & 1 & -- & -- & -- & -- & 520 \\
\hline 305 & 72 & -- & -- & 54 & $09 / 83$ & -- & -- & -- & -- & -- & 521 \\
\hline 405 & 35 & 6 & $70 / 170$ & -- & -- & -- & -- & -- & -- & -- & 522 \\
\hline 120 & 32 & 6 & $36 / 90 / 100$ & 22 & $08 / 81$ & 50 & $.86 / 50$ & 171 & 480 & 7.3 & 523 \\
\hline 118 & 111 & 6 & 115 & 50 & $07 / 83$ & 20 & -- & 68 & 165 & 7.2 & 524 \\
\hline 100 & 21 & -- & -- & 52 & $09 / 83$ & -- & $74 / 20$ & 222 & 370 & -- & 525 \\
\hline 80 & 35 & 6 & 77 & 40 & $09 / 83$ & -- & -- & 205 & 590 & 7.9 & 526 \\
\hline 200 & 52 & 6 & $100 / 140 / 180$ & -- & -- & 4 & -- & -- & -- & -- & 527 \\
\hline 240 & 25 & 6 & 195 & 75 & $07 / 82$ & 4 & $.03 / 4$ & -- & -- & -- & 528 \\
\hline 123 & 23 & 6 & -- & 47 & $09 / 83$ & -- & -- & 205 & 570 & 7.4 & 529 \\
\hline 100 & 28 & 6 & $35 / 45 / 65$ & 28 & $09 / 83$ & 9 & -- & 188 & 490 & 7.6 & 530 \\
\hline 100 & 96 & 8 & $77 / 94$ & 46 & $09 / 83$ & 50 & $2.0 / 50$ & 170 & 420 & 7.8 & 531 \\
\hline 117 & 108 & 6 & $100 / 110$ & 80 & $02 / 82$ & 20 & $1.00 / 20$ & -- & -- & -- & 532 \\
\hline 150 & 130 & 6 & $137 / 148$ & 70 & $08 / 81$ & 30 & $.49 / 30$ & -- & -- & -- & 533 \\
\hline 141 & 126 & 8 & $85 / 120 / 138$ & 75 & $10 / 81$ & 50 & $1.1 / 50$ & -- & -- & -- & 534 \\
\hline 303 & 20 & 6 & $194 / 205 / 265$ & 180 & $10 / 82$ & 8 & $.08 / 8$ & -- & -- & -- & 535 \\
\hline 243 & 224 & 6 & $223 / 235 / 243$ & 100 & $12 / 78$ & 35 & -- & -- & -- & -- & 536 \\
\hline 97 & 87 & 8 & 85 & 50 & $02 / 83$ & 15 & -- & -- & -- & -- & 537 \\
\hline 71 & 21 & 6 & $57 / 63$ & 11 & $09 / 83$ & 75 & -- & 171 & 575 & 7.4 & 538 \\
\hline 240 & 16 & 8 & $150 / 230$ & 107 & $09 / 83$ & 4 & -- & 205 & 540 & 7.4 & 539 \\
\hline 300 & 21 & 6 & $187 / 190 / 280$ & 150 & $06 / 78$ & 10 & -- & 119 & 300 & 7.5 & 540 \\
\hline 181 & 181 & 6 & -- & 135 & $09 / 83$ & -- & -- & -- & -- & -- & 541 \\
\hline 254 & 40 & 6 & $141 / 242$ & 150 & $10 / 80$ & 20 & $.28 / 20$ & -- & -- & -- & 542 \\
\hline 328 & 25 & 6 & $142 / 305$ & 25 & $09 / 83$ & 2 & -- & 68 & 200 & 7.6 & 543 \\
\hline 305 & 42 & 6 & 172 & 204 & $09 / 83$ & 20 & -- & 68 & 215 & 7.4 & 544 \\
\hline 100 & 26 & 8 & 43 & 10 & $01 / 81$ & 8 & $.08 / 8$ & -- & -- & -- & 545 \\
\hline 182 & 20 & 6 & $40 / 60$ & 40 & $04 / 78$ & 3 & $.15 / 3$ & -- & -- & -- & 546 \\
\hline 96 & 20 & 8 & 83 & -- & -- & 12 & -- & -- & -- & -- & 547 \\
\hline 70 & 20 & 8 & $40 / 60$ & 29 & $09 / 83$ & 6 & -- & -- & -- & -- & 548 \\
\hline 243 & 21 & 6 & $50 / 120 / 165 / 200$ & 40 & $06 / 77$ & 2 & $.01 / 2$ & -- & -- & -- & 549 \\
\hline 475 & 50 & 8 & $209 / 217$ & 142 & $10 / 83$ & 35 & -- & -- & -- & -- & 550 \\
\hline 425 & 40 & 8 & $146 / 342$ & 134 & $10 / 83$ & 60 & -- & -- & -- & -- & 551 \\
\hline 203 & 21 & 8 & $40 / 59 / 100 / 197$ & 100 & $04 / 79$ & 23 & $.46 / 23$ & -- & -- & -- & 552 \\
\hline 250 & -- & -- & -- & -- & -- & -- & -- & 205 & 530 & 7.1 & 553 \\
\hline 473 & -- & -- & -- & -- & -- & -- & -- & -- & -- & -- & 554 \\
\hline 387 & 37 & 6 & -- & 143 & $10 / 83$ & 6 & $.03 / 6$ & 226 & 620 & 7.6 & 555 \\
\hline 100 & 21 & 6 & $69 / 80$ & 26 & $10 / 83$ & 30 & $.75 / 30$ & 188 & 460 & 7.6 & 556 \\
\hline 165 & 32 & 8 & 140 & -- & -- & 20 & -- & -- & -- & -- & 557 \\
\hline 165 & 31 & 8 & $115 / 150$ & 100 & $09 / 82$ & 10 & -- & -- & -- & -- & 558 \\
\hline 145 & 111 & 8 & 135 & -- & -- & 20 & -- & -- & -- & -- & 559 \\
\hline 408 & 147 & 8 & $171 / 246$ & 159 & $10 / 83$ & 5 & $.04 / 5$ & 256 & 440 & 7.6 & 560 \\
\hline 225 & 61 & 6 & $167 / 190$ & -- & -- & 4 & -- & -- & -- & -- & 561 \\
\hline 151 & 132 & 4 & 136 & 120 & $06 / 83$ & 15 & $1.00 / 15$ & -- & -- & -- & 562 \\
\hline 725 & -- & -- & 200 & -- & -- & -- & -- & -- & -- & -- & 563 \\
\hline 59 & 40 & 8 & 42 & 30 & $10 / 79$ & 5 & $.50 / 5$ & 225 & 530 & 7.8 & 564 \\
\hline 125 & 105 & 8 & $100 / 123$ & 91 & $06 / 81$ & 20 & -- & -- & -- & -- & 565 \\
\hline 59 & 47 & 6 & $34 / 45$ & 27 & $10 / 83$ & 100 & $17 / 100$ & 258 & 580 & 7.4 & 566 \\
\hline
\end{tabular}




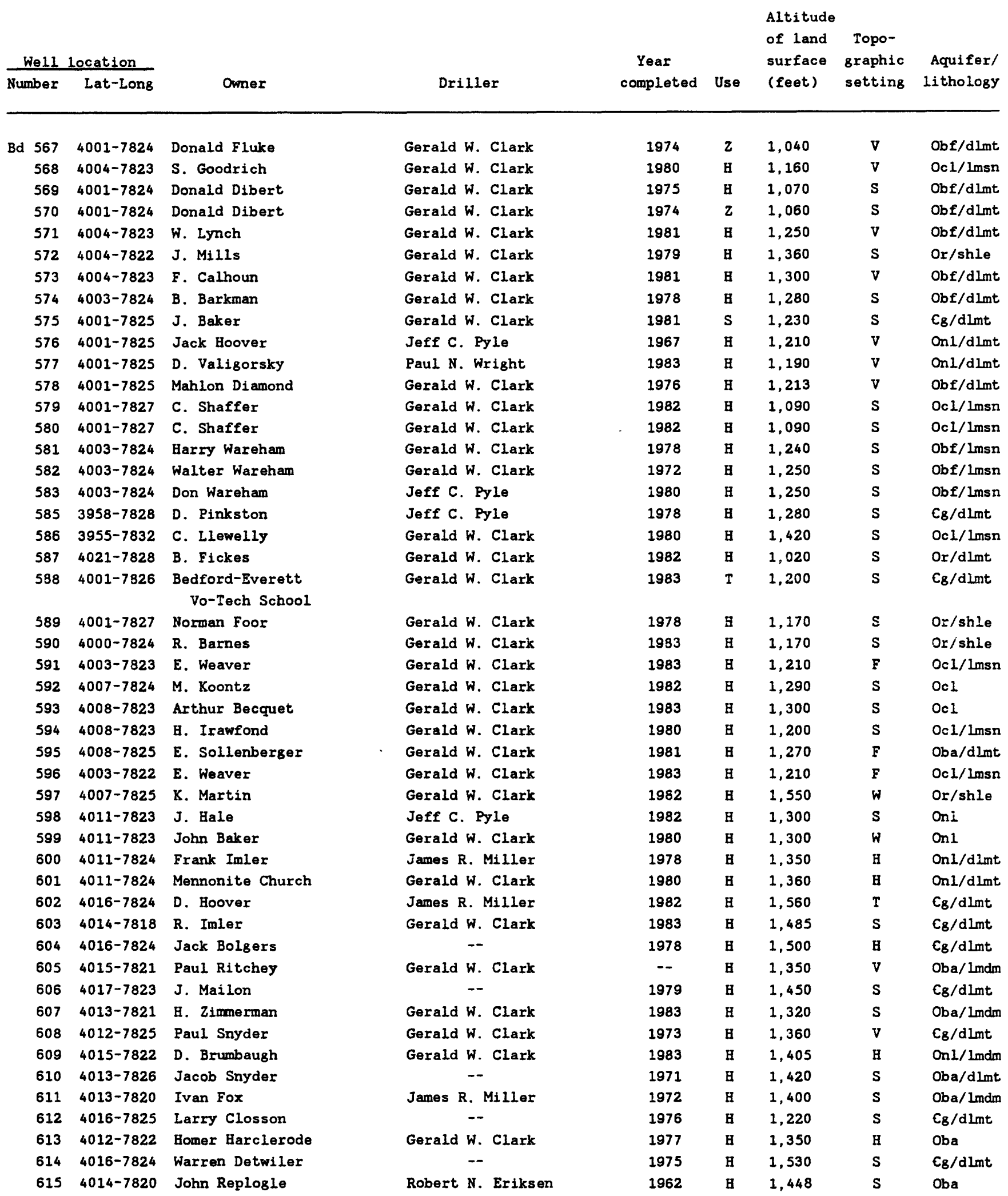




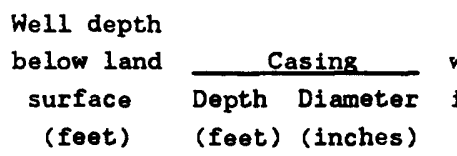

Depths to
water-bear-
ing zones

(feet)
Static water level

Depth below Date Reported Specific

land surface measured yield

(mo/yr) (gal/mi

capacity/ Hardness

Specific

conduc -

\begin{tabular}{|c|c|c|c|c|c|c|c|c|c|c|c|}
\hline 43 & 20 & 6 & 34 & 12 & $04 / 74$ & 75 & -- & -- & -- & -- & 567 \\
\hline 75 & 45 & 6 & $28 / 41 / 60$ & 45 & $10 / 83$ & 25 & $1.3 / 25$ & 111 & 480 & 7.7 & 568 \\
\hline 103 & 103 & 4 & 83 & 51 & $10 / 83$ & 10 & $0.20 / 10$ & -- & $\cdots$ & -- & 569 \\
\hline 163 & 24 & 6 & 96 & 96 & $11 / 74$ & 8 & -- & - & -- & -- & 570 \\
\hline 228 & 212 & 4 & 100 & 80 & $11 / 81$ & 7 & $.30 / 7$ & -- & -- & -- & 571 \\
\hline 83 & 20 & 6 & $58 / 63$ & 21 & $10 / 83$ & 20 & $.50 / 20$ & 103 & 250 & 7.7 & 572 \\
\hline 290 & 69 & 6 & $95 / 180 / 285$ & 80 & $01 / 81$ & 15 & $.07 / 15$ & -- & -- & -- & 573 \\
\hline 383 & 40 & 6 & $242 / 284 / 320$ & 62 & $10 / 83$ & 15 & $.06 / 15$ & 205 & 570 & 7.4 & 574 \\
\hline 182 & 148 & 6 & 162 & 141 & $07 / 81$ & 10 & $1.1 / 10$ & -- & -- & -- & 575 \\
\hline 283 & 45 & 6 & $100 / 180$ & 80 & $03 / 67$ & 3 & $.02 / 3$ & 273 & 700 & 7.2 & 576 \\
\hline 346 & 53 & 6 & $50 / 142 / 262 / 285$ & 71 & $10 / 83$ & 3 & $.01 / 3$ & -- & -- & $\cdots$ & 577 \\
\hline 243 & 17 & 6 & $54 / 210$ & 28 & $10 / 83$ & 2 & -- & 273 & 600 & 7.1 & 578 \\
\hline 113 & -- & 5 & 90 & 30 & $11 / 82$ & 30 & $.44 / 30$ & -- & - & -- & 579 \\
\hline 173 & 22 & 6 & $83 / 150$ & 36 & $10 / 83$ & 12 & $.12 / 12$ & -- & -- & -- & 580 \\
\hline 383 & 21 & 6 & $100 / 168 / 320$ & 70 & $11 / 78$ & 4 & $.01 / 4$ & -- & -- & -- & 581 \\
\hline 90 & 21 & 6 & 73 & 20 & $05 / 72$ & 12 & $.16 / 12$ & -- & -- & -- & 582 \\
\hline 105 & 71 & 6 & 90 & 32 & $10 / 83$ & 20 & -- & -- & -- & -- & 583 \\
\hline 245 & 21 & 6 & $120 / 135$ & 99 & $05 / 84$ & -- & $\cdots$ & 256 & 625 & -- & 585 \\
\hline 180 & 27 & 6 & $80 / 160$ & 41 & $04 / 83$ & 5 & $.03 / 5$ & 222 & 480 & 7.1 & 586 \\
\hline 141 & 43 & 6 & $78 / 130$ & 22 & $04 / 84$ & 7 & -- & 85 & 230 & 7.8 & 587 \\
\hline 244 & 95 & 6 & $151 / 201 / 213 / 223$ & 154 & $10 / 84$ & 50 & -- & -- & -- & -- & 588 \\
\hline 79 & 21 & 6 & $17 / 30 / 59$ & 8 & $01 / 78$ & 50 & -- & -- & -- & -- & 589 \\
\hline-- & 25 & 6 & $19 / 59 / 70$ & 25 & $04 / 84$ & 35 & $\cdots$ & 68 & 200 & 7.0 & 590 \\
\hline-- & 21 & 6 & $80 / 257 / 290 / 365$ & 53 & $04 / 84$ & 9 & -- & 188 & 490 & 7.1 & 591 \\
\hline 59 & 49 & 4 & $38 / 43$ & 5 & $04 / 84$ & 20 & -- & 102 & 360 & 6.8 & 592 \\
\hline 325 & 2 & 6 & $55 / 75$ & 49 & $04 / 84$ & 2 & -- & 119 & 350 & 6.6 & 593 \\
\hline 121 & 82 & 6 & $34 / 78 / 90 / 100$ & 23 & $04 / 84$ & 100 & -- & 102 & 300 & 7.1 & 594 \\
\hline 480 & 21 & 6 & $134 / 315 / 465$ & 28 & $04 / 84$ & - & - & 171 & 420 & 7.3 & 595 \\
\hline 180 & -- & $-\infty$ & -- & 2 & $04 / 84$ & -- & -- & -- & -- & -- & 596 \\
\hline 162 & 22 & 6 & $40 / 50 / 138$ & 12 & $04 / 84$ & 6 & $.09 / 6$ & 68 & 220 & 7.7 & 597 \\
\hline 105 & 31 & -- & 72 & -- & - & 10 & -- & -- & -- & -- & 598 \\
\hline 305 & 31 & 6 & $121 / 158 / 280$ & 150 & $11 / 80$ & 50 & -- & -- & -- & -- & 599 \\
\hline 177 & -- & -- & -- & 109 & $04 / 84$ & - & -- & 188 & 430 & 7.1 & 600 \\
\hline 160 & 66 & 6 & $127 / 137 / 142$ & 115 & $08 / 80$ & 18 & $.72 / 18$ & -- & -- & -- & 601 \\
\hline-- & -- & -- & -- & -- & -- & -- & -- & 68 & 110 & 7.9 & 602 \\
\hline 121 & 73 & 6 & $100 / 106 / 112$ & 53 & $05 / 84$ & 25 & $.80 / 25$ & 171 & 305 & - & 603 \\
\hline 390 & -- & -- & -- & -- & - & - & -- & 119 & 260 & 7.8 & 604 \\
\hline-- & $\cdots$ & -- & -- & 10 & $05 / 84$ & - & $\cdots$ & 290 & 615 & -- & 605 \\
\hline 221 & -- & -- & -- & -- & - & -- & $\ldots$ & 68 & 200 & 7.7 & 606 \\
\hline 408 & 21 & 6 & $8 / 25 / 230$ & 9 & $06 / 84$ & -- & $.03 / 4$ & - & -- & -- & 607 \\
\hline-- & -- & - & $\cdots$ & 17 & $05 / 84$ & -- & -- & 290 & 415 & 7.5 & 608 \\
\hline 241 & 225 & 4 & $217 / 230$ & 124 & $06 / 84$ & -- & -- & 188 & 410 & - & 609 \\
\hline 155 & 106 & 6 & 140 & 34 & $05 / 84$ & 15 & -- & 153 & 460 & 7.9 & 610 \\
\hline 66 & 20 & 6 & $20 / 50 / 60$ & 10 & $06 / 84$ & 18 & -- & 290 & 660 & - & 611 \\
\hline-- & 150 & 6 & -- & 65 & $05 / 84$ & -- & -- & 17 & 60 & 6.4 & 612 \\
\hline 418 & 21 & 6 & $120 / 278 / 318 / 398$ & 200 & $07 / 77$ & 6 & $.04 / 6$ & -- & - & - & 613 \\
\hline- & -- & -- & -- & -- & -- & -- & -- & 188 & 420 & 7.2 & 614 \\
\hline 126 & -- & -- & -- & 43 & $06 / 84$ & -- & -- & 239 & 490 & -- & 615 \\
\hline
\end{tabular}




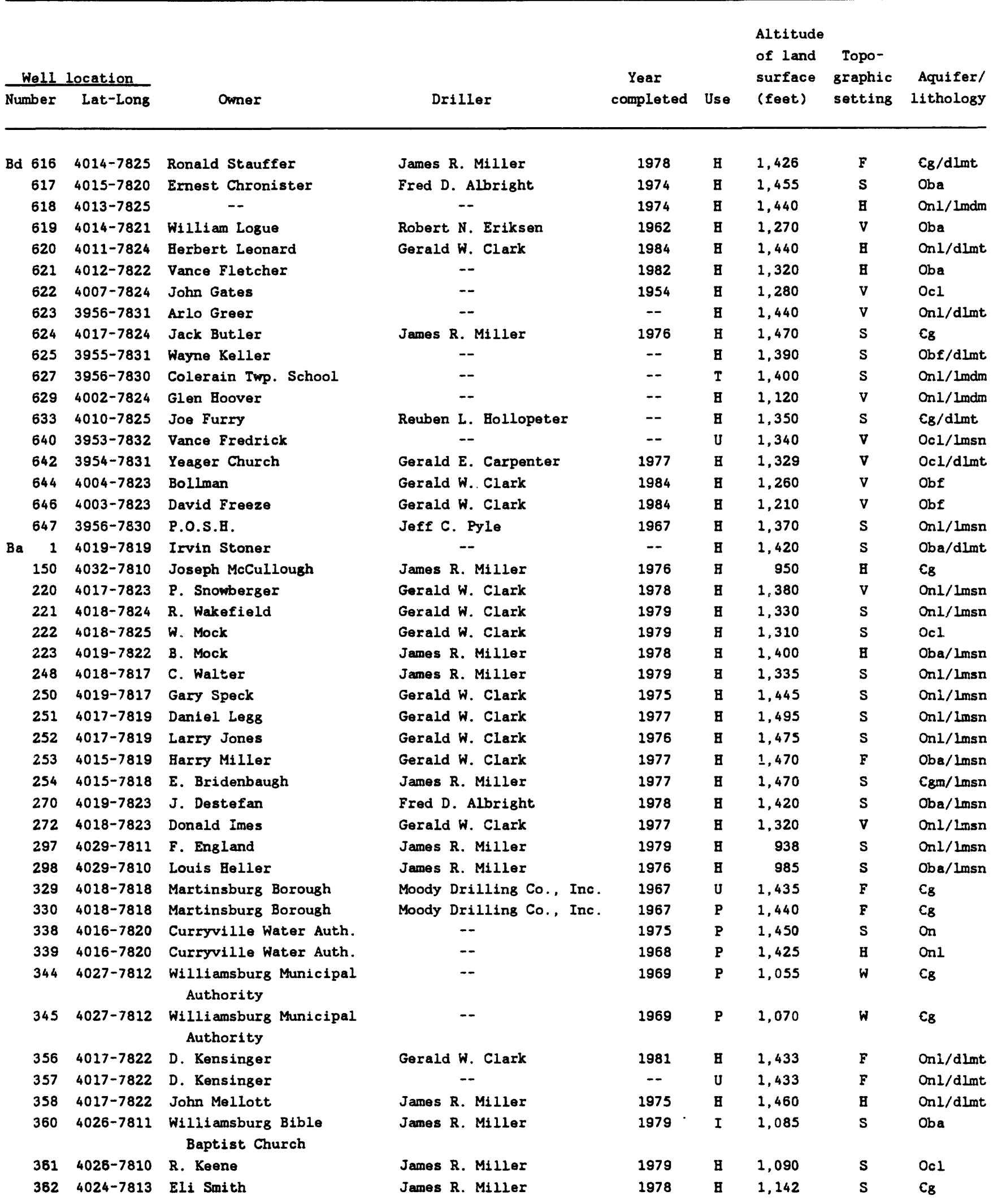


Well depth below land surface (feet) $\frac{\text { Casing }}{\text { Depth Diameter }}$ (feet) (inches)
Depths to Static water level water-bear- Depth below Date Reported Specific

ing zones land surface measured yield capacity/

(mo/yr) (gal/min) Rate
Specific

conduc-

$(\mathrm{mg} / \mathrm{L}) \quad(\mu \mathrm{S} / \mathrm{cm}) \quad \mathrm{pH}$ number

\begin{tabular}{|c|c|c|c|c|c|c|c|c|c|c|c|}
\hline 285 & -- & -- & -- & 46 & $05 / 84$ & -- & -- & 17 & 300 & 8.6 & $616 \mathrm{Bd}$ \\
\hline 148 & 46 & 6 & 140 & 46 & $06 / 84$ & 7 & -- & -- & -- & -- & 617 \\
\hline 400 & -- & -- & -- & -- & -- & -- & -- & 188 & 600 & 7.7 & 618 \\
\hline 50 & -- & -- & -- & 9 & $06 / 84$ & -- & -- & 256 & 520 & -- & 619 \\
\hline 162 & 21 & 6 & $74 / 121 / 135$ & 91 & $05 / 84$ & 7 & $0.30 / 7$ & 290 & 760 & 7.4 & 620 \\
\hline 250 & -- & 6 & -- & 59 & $06 / 84$ & 6 & $.20 / 4.2$ & 427 & 1,050 & -- & 621 \\
\hline 130 & -- & -- & -- & 40 & $05 / 84$ & -- & -- & 307 & 725 & 7.5 & 622 \\
\hline 325 & -- & -- & -- & 166 & $07 / 84$ & -- & -- & 273 & 565 & -- & 623 \\
\hline 510 & 201 & 6 & 300 & -- & -- & -- & -- & 205 & 540 & 7.3 & 624 \\
\hline 50 & -- & -- & -- & 23 & $07 / 84$ & -- & -- & 342 & 650 & -- & 625 \\
\hline-- & -- & -- & -- & 100 & $07 / 84$ & -- & -- & -- & -- & -- & 627 \\
\hline-- & -- & -- & -- & 16 & $07 / 84$ & 50 & -- & 256 & 520 & 7.7 & 629 \\
\hline 110 & -- & -- & -- & 72 & $07 / 84$ & 50 & -- & 102 & 240 & -- & 633 \\
\hline-- & -- & -- & $=-$ & 13 & $08 / 84$ & -- & -- & -- & 465 & 7.9 & 640 \\
\hline 248 & 42 & 6 & 90 & 35 & $10 / 84$ & 75 & -- & -- & -- & -- & 642 \\
\hline-- & -- & -- & -- & 59 & $10 / 84$ & -- & -- & -- & -- & -- & 644 \\
\hline 480 & -- & -- & -- & 71 & $10 / 84$ & -- & -- & -- & -- & -- & 646 \\
\hline 63 & 21 & 6 & 40 & 32 & $02 / 67$ & 15 & -- & -- & -- & -- & 647 \\
\hline 180 & 12 & 5 & -- & 50 & $08 / 33$ & 9 & $.90 / 9$ & -- & -- & -- & $1 \mathrm{Ba}$ \\
\hline 223 & -- & -- & -- & -- & -- & 1 & -- & 256 & 509 & -- & 150 \\
\hline 162 & 93 & 6 & $141 / 158$ & 100 & $11 / 78$ & 15 & $.50 / 15$ & -- & -- & -- & 220 \\
\hline 326 & 54 & 6 & $200 / 280 / 315$ & 80 & $08 / 79$ & 15 & $.07 / 15$ & -- & -- & -- & 221 \\
\hline 264 & 20 & 6 & $58 / 223 / 264$ & 100 & $10 / 79$ & 6 & $.06 / 6$ & -- & -- & -- & 222 \\
\hline 182 & 102 & 5 & $137 / 150$ & 121 & $06 / 80$ & 9 & -- & 340 & 605 & -- & 223 \\
\hline 145 & 60 & 6 & 135 & 58 & $06 / 80$ & 8 & -- & 188 & 450 & -- & 248 \\
\hline 261 & 66 & 6 & $143 / 235 / 250 / 258$ & 100 & $07 / 75$ & 15 & $.07 / 15$ & 120 & 250 & -- & 250 \\
\hline 152 & -- & 6 & 133 & 120 & $03 / 77$ & 8 & $.62 / 8$ & -- & -- & -- & 251 \\
\hline 261 & 107 & 6 & $122 / 230$ & 100 & $03 / 76$ & 6 & $.05 / 6$ & -- & -- & -- & 252 \\
\hline 123 & 19 & 6 & 113 & 83 & $03 / 77$ & 6 & $.30 / 6$ & -- & -- & -- & 253 \\
\hline 285 & 175 & 6 & $240 / 275$ & 169 & $06 / 80$ & 60 & -- & 137 & 305 & -- & 254 \\
\hline 360 & 46 & 6 & $350 / 355$ & 118 & $07 / 80$ & 12 & -- & 291 & 605 & -- & 270 \\
\hline 143 & 116 & 6 & $120 / 126 / 130$ & 89 & $07 / 80$ & 12 & $40 / 12$ & 154 & 435 & -- & 272 \\
\hline 247 & 57 & 6 & $222 / 230$ & -- & -- & 2 & -- & 205 & 427 & 7.0 & 297 \\
\hline 500 & 21 & 6 & $105 / 215 / 433$ & -- & -- & 8 & -- & 308 & 605 & 7.3 & 298 \\
\hline 296 & 223 & 6 & 140 & 97 & $05 / 67$ & -- & $10.0 / 230$ & -- & -- & -- & 329 \\
\hline 350 & 145 & 6 & 162 & 94 & $03 / 67$ & -- & $13 / 230$ & -- & -- & -- & 330 \\
\hline 396 & -- & -- & -- & 49 & $03 / 75$ & -- & $.04 / 12$ & -- & -- & -- & 338 \\
\hline 223 & 45 & 6 & -- & -- & -- & 150 & -- & -- & -- & -- & 339 \\
\hline 487 & 116 & 8 & -- & 210 & $01 / 69$ & 300 & $7.1 / 300$ & -- & -- & -- & 344 \\
\hline 417 & 264 & 8 & -- & 219 & $01 / 69$ & 300 & $30 / 300$ & -- & -- & -- & 345 \\
\hline 525 & 123 & 6 & $223 / 302 / 420$ & 136 & $10 / 83$ & 15 & $.05 / 15$ & 153 & 400 & 1.0 & 356 \\
\hline 225 & -- & -- & -- & 124 & $10 / 83$ & -- & -- & -- & -- & -- & 357 \\
\hline 240 & 58 & 6 & $218 / 230$ & -- & -- & -- & -- & -- & -- & -- & 358 \\
\hline 217 & 211 & 4 & $95 / 200$ & -- & -- & 10 & -- & 391 & 813 & -- & 360 \\
\hline 400 & 111 & 6 & $350 / 390$ & -- & -- & 3 & -- & 154 & 335 & 7.2 & 361 \\
\hline 125 & 115 & 4 & 98 & -- & -- & 18 & -- & 240 & 467 & -- & 362 \\
\hline
\end{tabular}




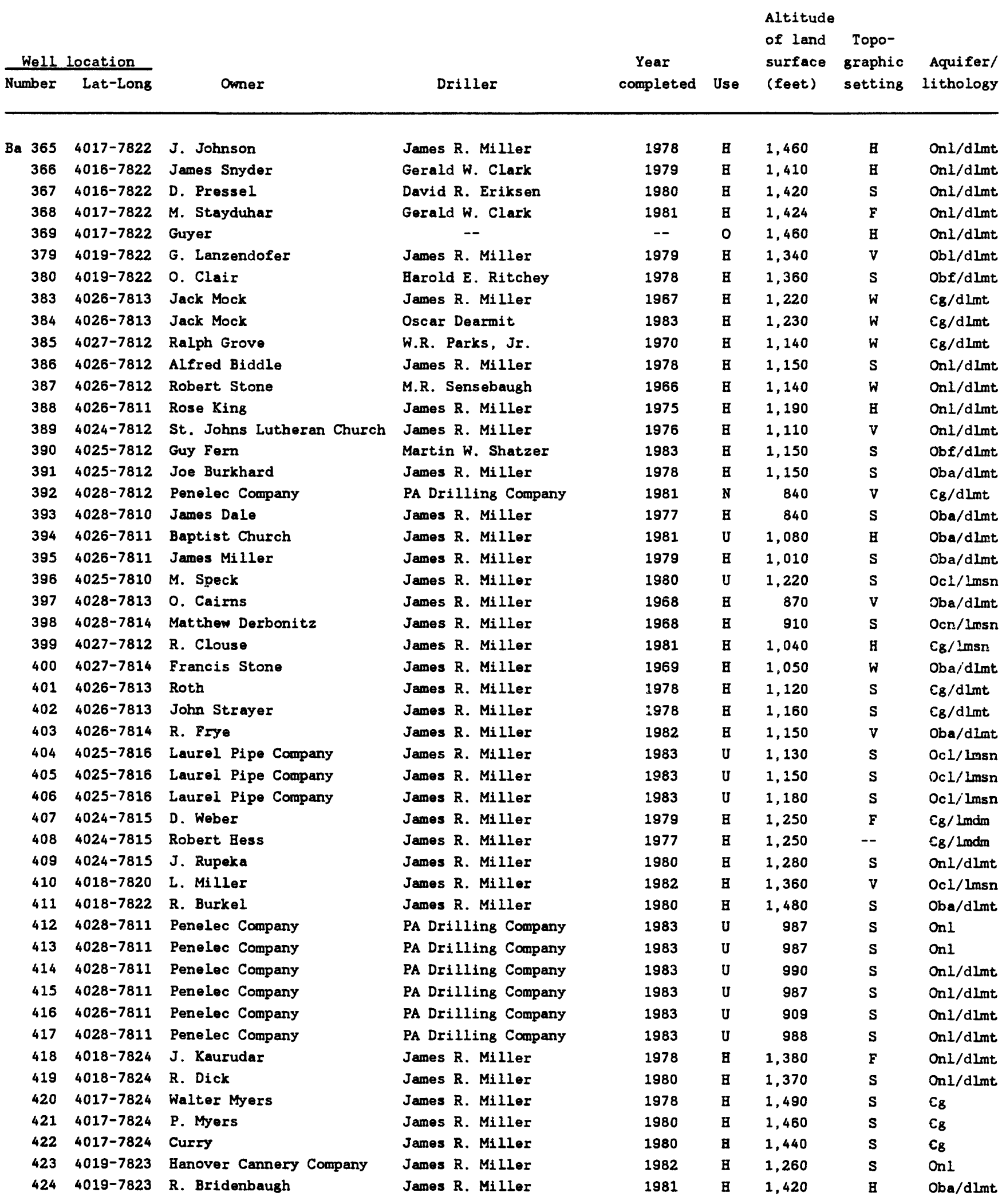


Well depth below land surface (fe日t)

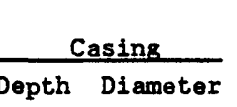

(feet) (inches)
Depths to

water-bear- Depth below Date Reported Specific

ing zones land surface measured yield

(feet)

(feet) (mo/yr) (gal/min)
Rate
Specific

conduc-

capacity/ Hardness tance

$(\mathrm{mg} / \mathrm{L}) \quad(\mu \mathrm{S} / \mathrm{cm}) \quad \mathrm{pH}$ number

\begin{tabular}{|c|c|c|c|c|c|c|c|c|c|c|c|}
\hline 205 & 200 & 4 & $180 / 188$ & -- & -- & 21 & -- & -- & -- & -- & 365 \\
\hline 187 & 177 & 4 & $135 / 165$ & -- & -- & 15 & $0.88 / 15$ & -- & -- & -- & 366 \\
\hline 225 & 15 & 6 & $125 / 205 / 210$ & 129 & $10 / 83$ & 7 & -- & -- & -- & -- & 367 \\
\hline 285 & 138 & 5 & $195 / 223 / 257$ & 110 & $12 / 81$ & 20 & $.14 / 20$ & -- & -- & -- & 368 \\
\hline 329 & -- & -- & -- & 146 & $10 / 83$ & -- & -- & -- & -- & -- & 369 \\
\hline 145 & 132 & 4 & $110 / 130$ & 110 & $12 / 81$ & 36 & -- & -- & -- & -- & 379 \\
\hline 270 & 21 & 6 & 252 & 112 & $10 / 83$ & 3 & -- & 308 & 975 & 6.9 & 380 \\
\hline 272 & 62 & 6 & $225 / 262$ & 250 & $10 / 67$ & 10 & -- & -- & -- & -- & 383 \\
\hline 329 & -- & -- & -- & 248 & $04 / 84$ & -- & -- & -- & -- & -- & 384 \\
\hline 143 & -- & -- & -- & 124 & $01 / 70$ & 6 & -- & -- & -- & -- & 385 \\
\hline 225 & 220 & 4 & 192 & -- & -- & 9 & -- & 188 & 370 & 7.4 & 386 \\
\hline 170 & 62 & 6 & 157 & 147 & $12 / 66$ & 15 & -- & -- & -- & -- & 387 \\
\hline 325 & 21 & 6 & 210 & 150 & $07 / 75$ & 5 & -- & 307 & 810 & 6.8 & 388 \\
\hline 105 & 46 & 6 & $70 / 100$ & 54 & $04 / 84$ & 18 & -- & 205 & 480 & 7.2 & 389 \\
\hline 180 & -- & -- & -- & 105 & $04 / 84$ & 18 & $2.6 / 6$ & 273 & 600 & 6.6 & 390 \\
\hline 185 & 180 & 4 & $140 / 160$ & -- & -- & 12 & -- & -- & -- & -- & 391 \\
\hline 357 & 57 & 8 & $92 / 117 / 157$ & 6 & $04 / 84$ & 100 & $2.0 / 100$ & -- & -- & -- & 392 \\
\hline 165 & 85 & 6 & 103 & -- & -- & 36 & -- & -- & -- & -- & 393 \\
\hline 386 & 21 & 6 & $151 / 355 / 375$ & 28 & $04 / 84$ & -- & $.004 / 2.0$ & 307 & 620 & 7.2 & 394 \\
\hline 260 & 21 & 6 & 245 & -- & -- & -- & -- & 307 & 750 & 6.9 & 395 \\
\hline 411 & 36 & 6 & 309 & 15 & $04 / 84$ & 1 & -- & -- & -- & -- & 396 \\
\hline 152 & 20 & 6 & $20 / 64 / 134$ & 20 & $10 / 68$ & 3 & $.03 / 3$ & 256 & 1,200 & 6.9 & 397 \\
\hline 68 & 20 & 6 & 42 & 18 & $09 / 68$ & 2 & $.08 / 2$ & 376 & 775 & 6.8 & 398 \\
\hline 349 & 21 & 6 & $100 / 320$ & 150 & $04 / 84$ & 1 & -- & 171 & 490 & 7.0 & 399 \\
\hline 128 & 70 & 6 & 122 & 92 & $08 / 69$ & 15 & $.50 / 15$ & 307 & 700 & 6.7 & 400 \\
\hline 355 & 208 & 6 & $295 / 335$ & 215 & $04 / 84$ & -- & -- & 135 & 290 & 7.3 & 401 \\
\hline-- & 300 & 4 & $217 / 320$ & -- & -- & 6 & -- & 51 & 140 & 7.1 & 402 \\
\hline 206 & 206 & 4 & 196 & 103 & $04 / 84$ & 12 & -- & 239 & 650 & 7.1 & 403 \\
\hline 107 & 57 & 12 & 58 & -- & -- & 75 & -- & -- & -- & -- & 404 \\
\hline 112 & 44 & 6 & $70 / 101$ & 49 & $10 / 83$ & 30 & -- & -- & -- & -- & 405 \\
\hline 87 & 64 & 6 & 67 & 86 & $10 / 83$ & 1 & -- & -- & -- & -- & 406 \\
\hline 217 & 164 & 6 & 190 & 117 & $04 / 84$ & 4 & -- & 119 & 250 & 7.5 & 407 \\
\hline 450 & 45 & 6 & -- & -- & -- & 1 & -- & -- & -- & -- & 408 \\
\hline 305 & 148 & 6 & $200 / 246$ & 114 & $11 / 80$ & 3 & -- & 205 & 490 & 7.2 & 409 \\
\hline 83 & 20 & 6 & 64 & -- & -- & 40 & -- & 290 & 710 & 7.0 & 410 \\
\hline 267 & 37 & 6 & $236 / 256$ & -- & -- & 4 & -- & -- & -- & -- & 411 \\
\hline 160 & 156 & 4 & -- & 123 & $03 / 84$ & -- & -- & -- & 430 & 7.2 & 412 \\
\hline 158 & 153 & 4 & -- & 119 & $03 / 84$ & 3 & -- & -- & 330 & 7.4 & 413 \\
\hline 164 & 164 & 4 & -- & 125 & $03 / 84$ & -- & -- & -- & 310 & 7.5 & 414 \\
\hline-- & 156 & 4 & -- & 124 & $03 / 84$ & 1 & -- & -- & 390 & 7.5 & 415 \\
\hline 90 & 83 & 4 & -- & 48 & $03 / 84$ & 4 & $3.1 / 4$ & -- & 307 & 7.4 & 416 \\
\hline 160 & 155 & 4 & -- & 120 & $04 / 84$ & -- & -- & -- & 580 & 7.3 & 417 \\
\hline 185 & 175 & 4 & -- & -- & -- & 10 & -- & -- & -- & -- & 418 \\
\hline 400 & 400 & 4 & 145 & 30 & $10 / 80$ & 1 & -- & 342 & 900 & 6.8 & 419 \\
\hline 305 & 131 & 5 & -- & 246 & $04 / 84$ & 5 & -- & 119 & 320 & 7.3 & 420 \\
\hline 322 & 169 & 6 & -- & 234 & $04 / 84$ & 16 & -- & 153 & 350 & 7.6 & 421 \\
\hline 225 & 195 & 6 & 198 & -- & -- & 18 & -- & -- & -- & -- & 422 \\
\hline 206 & 20 & 6 & 123 & 79 & $04 / 84$ & 2 & $.08 / 5.3$ & 307 & 975 & 7.1 & 423 \\
\hline 400 & 21 & 6 & $252 / 390$ & 120 & $04 / 84$ & 12 & -- & 239 & 510 & 7.2 & 424 \\
\hline
\end{tabular}




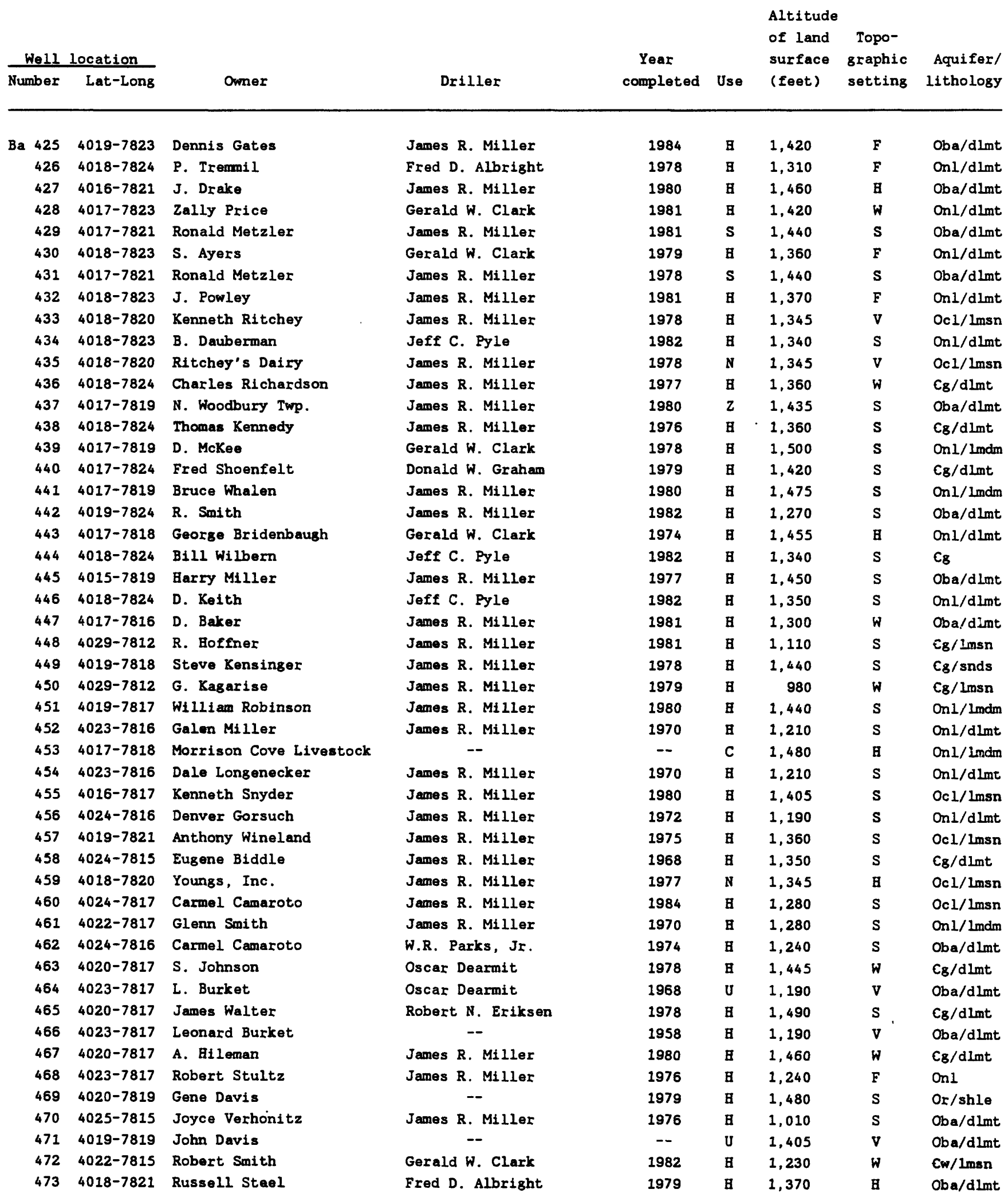




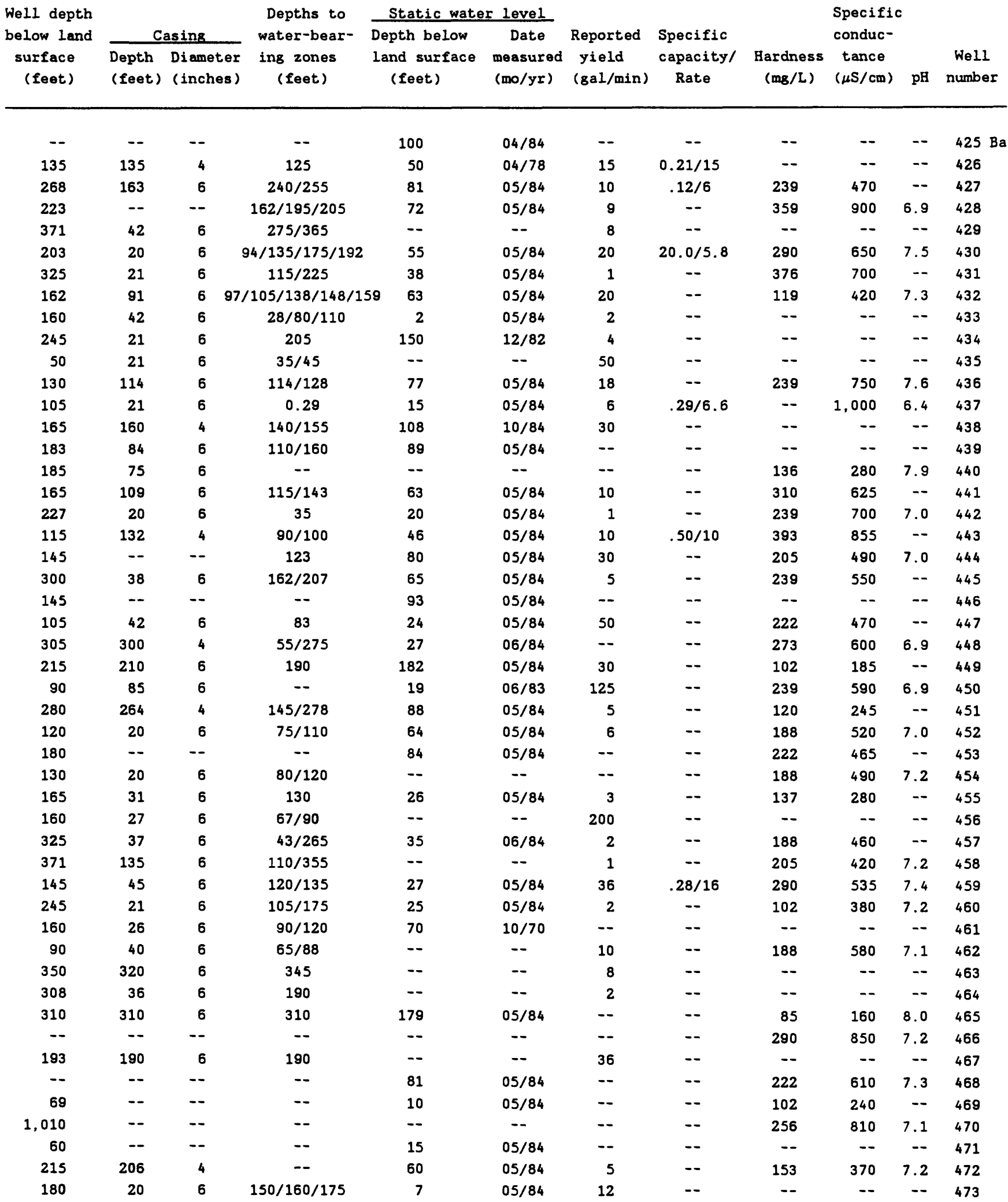




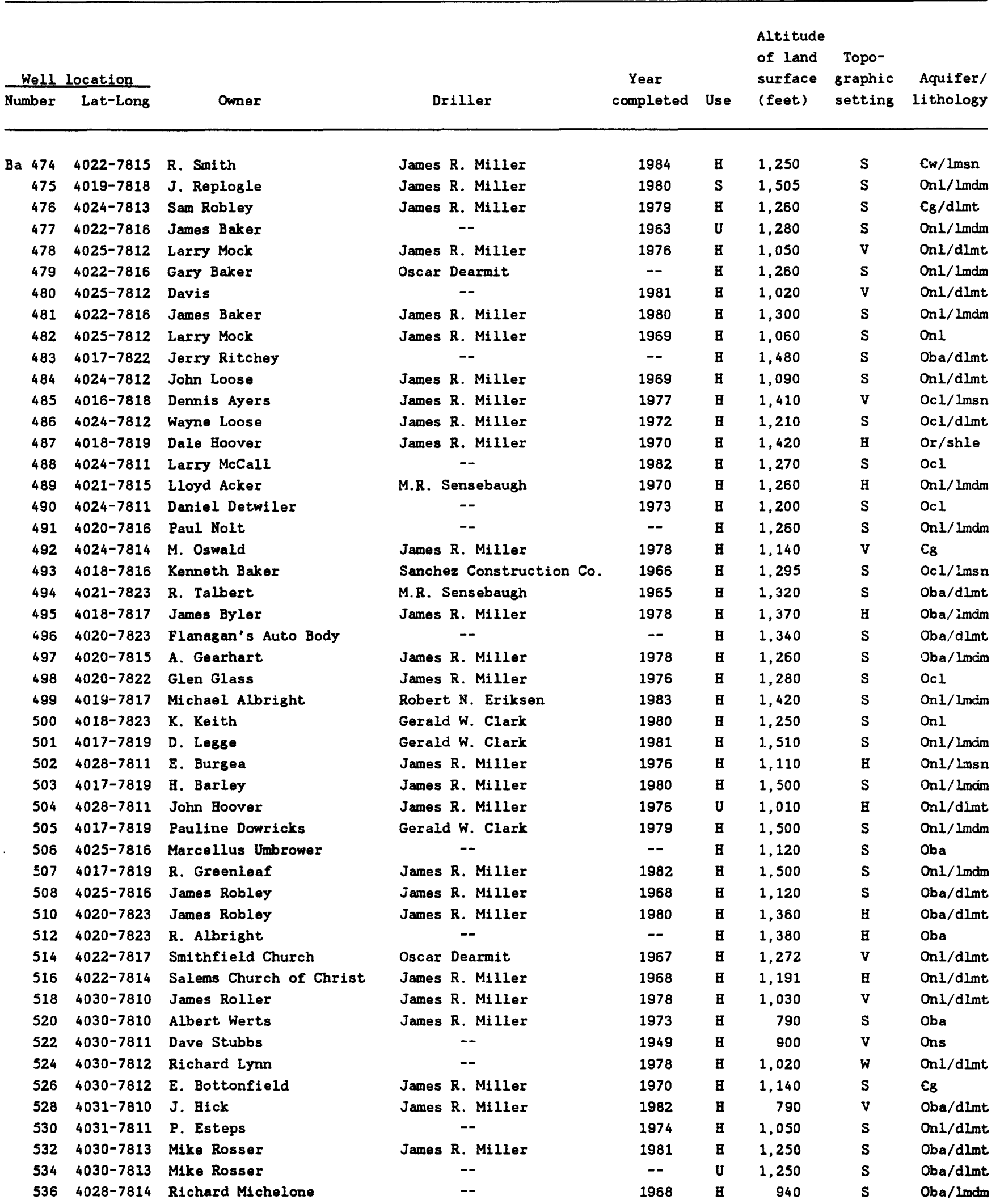


Well depth

surface

(feet)

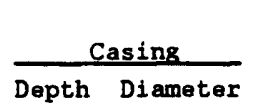

(feet) (inches)
Depths to

ing zones

(feet)

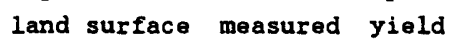

(feet)
Specific

conduc-

capacity/ Hardness tance

(mg/L) $(\mu \mathrm{S} / \mathrm{cm})$ pH number

\begin{tabular}{|c|c|c|c|c|c|c|c|c|c|c|c|}
\hline 182 & 38 & 6 & $100 / 150 / 160$ & 90 & $05 / 84$ & 12 & -- & 136 & 350 & 7.2 & 474 \\
\hline 195 & 186 & 4 & $153 / 185$ & 138 & $05 / 84$ & 7 & -- & 205 & 500 & -- & 475 \\
\hline-- & -- & -- & -- & 186 & $05 / 84$ & -- & -- & 119 & 280 & 7.2 & 476 \\
\hline 400 & -- & -- & -- & 16 & $05 / 84$ & -- & -- & -- & -- & -- & 477 \\
\hline 125 & 20 & 6 & $70 / 120$ & 41 & $05 / 84$ & 4 & -- & -- & -- & -- & 478 \\
\hline-- & -- & -- & 30 & 18 & $05 / 84$ & -- & $0.17 / 10$ & 222 & 410 & 7.6 & 479 \\
\hline 65 & -- & -- & -- & -- & -- & 26 & -- & -- & -- & -- & 480 \\
\hline-- & -- & 6 & -- & 76 & $05 / 84$ & -- & -- & 137 & 300 & -- & 481 \\
\hline 87 & 82 & 6 & $74 / 85$ & 40 & $10 / 84$ & 30 & -- & 239 & 675 & 7.1 & 482 \\
\hline 203 & -- & 6 & -- & 99 & $05 / 84$ & 15 & $.30 / 15$ & 256 & 560 & -- & 483 \\
\hline 122 & 18 & 6 & $95 / 118$ & 37 & $05 / 84$ & 100 & -- & 188 & 420 & 7.4 & 484 \\
\hline 90 & 87 & 6 & 89 & 44 & $06 / 84$ & 20 & $2.30 / 8.0$ & 239 & 540 & 7.8 & 485 \\
\hline 190 & 35 & 6 & $138 / 178$ & 40 & $01 / 72$ & 5 & -- & 119 & 300 & 7.6 & 486 \\
\hline 107 & 19 & 6 & -- & 11 & $06 / 84$ & 6 & $.07 / 6$ & -- & -- & -- & 487 \\
\hline 350 & -- & -- & -- & 58 & $05 / 84$ & -- & -- & 205 & 525 & 7.2 & 488 \\
\hline 123 & 118 & 6 & 118 & 83 & $06 / 84$ & 15 & -- & 239 & 495 & -- & 489 \\
\hline 270 & -- & -- & -- & -- & -- & 1 & -- & 256 & 740 & 7.1 & 490 \\
\hline 70 & -- & -- & -- & 31 & $06 / 84$ & -- & -- & -- & 550 & 7.9 & 491 \\
\hline 145 & 145 & 4 & $115 / 132$ & -- & -- & 30 & -- & -- & -- & -- & 492 \\
\hline 100 & 28 & 6 & $40 / 60 / 75$ & 17 & $06 / 84$ & 3 & $.04 / 3$ & 154 & 360 & 7.5 & 493 \\
\hline 210 & -- & -- & -- & 98 & $05 / 84$ & -- & -- & 205 & 510 & 7.6 & 494 \\
\hline 180 & 80 & -- & -- & 90 & $06 / 84$ & -- & -- & -- & 760 & 7.6 & 495 \\
\hline 55 & -- & -- & -- & 29 & $05 / 84$ & -- & -- & 239 & 520 & 7.3 & 496 \\
\hline 90 & 20 & 6 & $65 / 81$ & -- & -- & 10 & -- & -- & -- & -- & 497 \\
\hline 105 & 22 & 6 & -- & 51 & $05 / 83$ & -- & -- & 205 & 510 & 7.6 & 498 \\
\hline 170 & 135 & 6 & -- & 71 & $05 / 84$ & -- & -- & 171 & 330 & 7.7 & 499 \\
\hline 141 & 120 & 6 & 135 & 90 & $01 / 80$ & 15 & -- & -- & -- & -- & 500 \\
\hline 223 & 67 & 4 & -- & -- & -- & 13 & $.29 / 13$ & -- & -- & -- & 501 \\
\hline 240 & 240 & 6 & $200 / 232$ & -- & -- & -- & -- & -- & -- & -- & 502 \\
\hline 185 & 152 & 6 & 160 & -- & -- & 8 & -- & -- & -- & -- & 503 \\
\hline 245 & 246 & 4 & $215 / 230$ & 170 & $06 / 84$ & -- & -- & -- & -- & -- & 504 \\
\hline 141 & 127 & 4 & $91 / 111$ & -- & -- & 8 & $.40 / 8$ & -- & -- & -- & 505 \\
\hline-- & -- & -- & -- & 40 & $06 / 84$ & -- & -- & 342 & 900 & 7.2 & 506 \\
\hline 145 & 51 & 6 & $103 / 119 / 120$ & -- & -- & 30 & -- & -- & -- & -- & 507 \\
\hline 68 & 21 & 6 & -- & 39 & $06 / 84$ & 20 & -- & 239 & 600 & 7.2 & 508 \\
\hline 308 & 40 & 6 & $215 / 287$ & -- & -- & 8 & -- & -- & -- & -- & 510 \\
\hline-- & -- & -- & -- & 204 & $10 / 84$ & -- & -- & -- & -- & -- & 512 \\
\hline 126 & 30 & 6 & 123 & -- & -- & 13 & -- & -- & -- & -- & 514 \\
\hline 107 & 93 & 6 & $77 / 92 / 103$ & 61 & $06 / 84$ & 65 & -- & -- & 490 & 7.2 & 516 \\
\hline 221 & 39 & 6 & $99 / 210$ & -- & -- & 8 & -- & 239 & 675 & 7.2 & 518 \\
\hline 125 & -- & -- & -- & 47 & $06 / 84$ & -- & -- & 376 & 775 & 7.0 & 520 \\
\hline 88 & -- & -- & -- & 23 & $01 / 83$ & -- & -- & 239 & 560 & 7.0 & 522 \\
\hline 115 & -- & -- & -- & 26 & $06 / 84$ & 80 & -- & 205 & 540 & 7.5 & 524 \\
\hline-- & -- & -- & -- & -- & -- & -- & -- & 203 & 590 & 7.4 & 526 \\
\hline 125 & 33 & 6 & $49 / 111$ & 21 & $06 / 84$ & -- & -- & -- & -- & -- & 528 \\
\hline-- & -- & -- & -- & 82 & $06 / 84$ & -- & -- & 393 & 850 & 6.9 & 530 \\
\hline 167 & -- & -- & -- & 44 & $06 / 84$ & -- & -- & 85 & 280 & 7.4 & 532 \\
\hline-- & -- & -- & -- & 44 & $06 / 84$ & -- & -- & -- & -- & -- & 534 \\
\hline 110 & -- & -- & -- & -- & -- & 1 & -- & -- & -- & -- & 536 \\
\hline
\end{tabular}




\begin{tabular}{|c|c|c|c|c|c|c|c|c|}
\hline We11 & location & \multirow[b]{2}{*}{ Owner } & \multirow[b]{2}{*}{ Driller } & \multirow{2}{*}{$\begin{array}{c}\text { Year } \\
\text { completed }\end{array}$} & \multirow[b]{2}{*}{ Use } & \multirow{2}{*}{$\begin{array}{l}\text { Altitude } \\
\text { of land } \\
\text { surface } \\
\text { (feet) }\end{array}$} & \multirow{2}{*}{$\begin{array}{l}\text { Topo- } \\
\text { graphic } \\
\text { setting }\end{array}$} & \multirow{2}{*}{$\begin{array}{l}\text { Aquifer/ } \\
\text { lithology }\end{array}$} \\
\hline Number & Lat-Long & & & & & & & \\
\hline $\mathrm{Ba} 538$ & $4016-7821$ & P. Fox & James R. Miller & 1980 & H & 1,450 & $\mathbf{F}$ & Oba \\
\hline 541 & $4059-7827$ & -- & -- & -- & $\mathbf{E}$ & -- & E & Cg/dlmt \\
\hline 600 & $4037-7815$ & Harry Briggs & $-\infty$ & 1981 & E & 1,095 & $\mathbf{s}$ & Oba/Imsh \\
\hline 601 & $4039-7812$ & John Updike & -- & -- & U & 830 & $\mathbf{v}$ & Oba/Imdm \\
\hline 602 & $4032-7816$ & Dave Alberter & Barold E. Ritchey & 1972 & E & 1,170 & $\mathbf{v}$ & Ocl/1msh \\
\hline 603 & $4034-7815$ & Wiggers & W.R. Parks, Jr. & 1975 & E & 1,120 & V & Ocl/lmsh \\
\hline 604 & $4033-7815$ & Glenn Allbright & -- & -- & $\mathbf{S}$ & 1,080 & $\mathbf{V}$ & Ocl/lmsh \\
\hline 605 & $4033-7816$ & John Rizzo & Fred D. Albright & 1976 & E & 1,140 & $\mathbf{v}$ & Ocl/lmsh \\
\hline 606 & $4035-7816$ & Byron Kirkum & Wiley L. Gray & 1974 & E & 1,130 & V & Oc1/Imsh \\
\hline 607 & $4034-7815$ & Robert Black & -- & 1972 & E & 1,050 & $\mathbf{v}$ & Oba/Imdm \\
\hline 608 & $4036-7815$ & J. McCutchern & James R. Miller & 1976 & E & 1,185 & $\mathbf{v}$ & Ocl/Imsn \\
\hline 609 & $4035-7815$ & Frank Fleck & James R. Miller & 1974 & E & 1,160 & $\mathbf{V}$ & On 1/lmsn \\
\hline 610 & $4035-7813$ & Albert Schoenberger & - & 1979 & $\mathbf{B}$ & 950 & $\mathrm{U}$ & Ocl/Imsh \\
\hline 611 & $4037-7811$ & Torrence Yothers & James R. Miller & -- & E & 1,105 & $\mathbf{v}$ & Oba/lmdm \\
\hline 612 & $4036-7812$ & William Black & -- & -- & $\mathbf{U}$ & 1,140 & $\mathbf{v}$ & Oba/Imdm \\
\hline 613 & $4037-7813$ & Charlie Robison & Harold E. Ritchey & 1983 & E & 1,140 & $\mathbf{v}$ & On1/lmdm \\
\hline 614 & $4035-7816$ & Sinking Valley & -- & -- & $\mathbf{B}$ & 1,120 & $\mathbf{v}$ & $\mathrm{Oba} / 1$ mdm \\
\hline 615 & $4036-7814$ & Tom Crawford & -- & 1930 & $\mathbf{E}$ & 1,100 & $\mathbf{U}$ & Onl/Imsn \\
\hline 616 & $4035-7814$ & Senberg & -- & 1972 & E & 1,040 & $\mathbf{v}$ & Ocl/1mdm \\
\hline 617 & $4036-7812$ & W. Adams & $-\infty$ & -- & E & 900 & $\mathbf{v}$ & Ocl/Imsh \\
\hline 618 & $4031-7811$ & Vincent Leibal & -- & 1979 & E & 1,040 & $\mathbf{U}$ & Oba/Imdn \\
\hline 619 & $4030-7813$ & William Bigelow & -- & -- & $\mathbf{s}$ & 1,140 & $\mathbf{v}$ & Onl/lmsn \\
\hline 620 & $4030-7812$ & James Saylor & Barold E. Ritchey & 1964 & $\mathbf{S}$ & 1.060 & $\mathbf{U}$ & Onl/Imsn \\
\hline 621 & $4030-7810$ & R. Fischer & William Diehl & -- & $\mathbf{S}$ & 1,010 & $\mathbf{v}$ & Oba/Imdm \\
\hline 623 & $4037-7812$ & Charles Hoover & -- & -- & $\mathbf{U}$ & 1,150 & V & Onl \\
\hline 624 & $4038-7811$ & Michael Yeaton & Donald W. Graham & 1978 & E & 840 & $\mathbf{v}$ & Ocl/Imsh \\
\hline 625 & $4038-7814$ & Richard Koch & James P. Miller, II & -- & $\mathbf{B}$ & 1,140 & $\mathbf{s}$ & Oba/Imdn \\
\hline 626 & $4038-7813$ & Joe Smith & -- & -- & $\mathbf{U}$ & 1,095 & $\mathbf{v}$ & Onl/lmsn \\
\hline 627 & $4037-7813$ & Mabel Blacd & -- & -- & $\mathbf{U}$ & 1,070 & $\mathbf{S}$ & onl/Imam \\
\hline 628 & $4038-7814$ & Richard Koch & James P. Miller, II & 1985 & $\mathbf{B}$ & 1,140 & $\mathbf{s}$ & Oba/Imsm \\
\hline $\mathrm{Ce} \quad 94$ & $4042-7756$ & Penn State University & -- & 1961 & $\mathbf{H}$ & 1,226 & $\mathbf{v}$ & Ocl/Imsn \\
\hline 95 & $4048-7752$ & Penn State University & -- & 1962 & $\mathbf{U}$ & 1,092 & $\mathbf{v}$ & Ggl/dlmt \\
\hline 96 & $4048-7751$ & Penn State University & -- & 1962 & $\mathbf{U}$ & 1,130 & 旦 & On/dImt \\
\hline 97 & $4051-7750$ & Penn State University & -- & 1962 & $\mathbf{P}$ & 1,240 & 且 & Egm/dImt \\
\hline 98 & $4050-7752$ & Penn State University & -- & 1962 & $\mathbf{P}$ & 1,208 & $\mathbf{B}$ & Cgm/dImt \\
\hline 99 & $4049-7752$ & Penn State University & -- & 1963 & $\mathbf{B}$ & 1,038 & $\mathbf{v}$ & $\epsilon_{g 1 / d I m t}$ \\
\hline 101 & $4048-7752$ & Penn State University & -- & 1965 & $\mathbf{P}$ & 1,080 & $\mathbf{v}$ & $C_{g m / d I m t}$ \\
\hline 102 & $4048-7752$ & Penn State University & -- & 1938 & $\mathbf{P}$ & 1,065 & $\mathbf{V}$ & Egl/dlmt \\
\hline 103 & $4047-7752$ & Penn State University & PA Drilling Company & 1972 & $\mathbf{U}$ & 1,190 & $\mathbf{v}$ & On/dlmt \\
\hline 106 & $4047-7751$ & Penn State University & -- & 1938 & $\mathbf{P}$ & 1,161 & $\mathbf{S}$ & on/dlmt \\
\hline 107 & $4047-7751$ & Penn State University & -- & 1938 & $\mathbf{U}$ & 1,161 & $\mathbf{S}$ & On/dlmt \\
\hline 114 & $4049-7751$ & Penn State University & $-\infty$ & 1948 & $\mathbf{P}$ & 1,042 & V & $C_{g 1 / d} \operatorname{lm} t$ \\
\hline 116 & $4049-7752$ & Penn State University & $-\infty$ & 1948 & $\mathbf{U}$ & 1,092 & $\mathbf{v}$ & $\mathrm{Cgl/dlmt}$ \\
\hline 117 & $4049-7752$ & Penn State University & -- & 1949 & $\mathbf{P}$ & 1,076 & $\mathbf{v}$ & $C_{g 1 / d} \operatorname{lmt}$ \\
\hline 118 & $4045-7757$ & U.S. Geological Survey & Russe11 R. Brooks & 1967 & 0 & 1,150 & $\mathbf{v}$ & $\mathrm{Cg} 1 / \mathrm{dlm} t$ \\
\hline 119 & $4046-7757$ & PA Game Commission & Moody Drilling Co., Inc. & 1970 & $\mathbf{R}$ & 1,215 & $\mathbf{v}$ & $C_{g 1 / d l m t}$ \\
\hline 129 & $4049-7740$ & Centre Hall Borough & -- & 1973 & $\mathbf{U}$ & 1,275 & $\mathbf{v}$ & Obf/dlmt \\
\hline 132 & $4045-7754$ & Kenneth Bennet & -- & 1960 & 目 & 1,225 & $\mathbf{v}$ & $\epsilon_{g m} / \mathrm{d} \operatorname{lm} t$ \\
\hline 133 & $4049-7757$ & Centre Co. Assoc. & -- & 1958 & $\mathbf{P}$ & 1,320 & E & Obf $/ d \ln t$ \\
\hline
\end{tabular}


Well depth

below land surface

(feet)

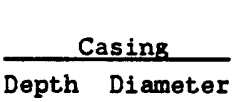

(feet) (inches)
Depths to Static water level

water-bear- Depth below Date Reported Specific

ing zones land surface measured yield capacity/ Hardness tance

Specific

conduc-

(feet) (feet)
Rate
(mg/L)
Well

$(\mu \mathrm{S} / \mathrm{cm})$ pH number

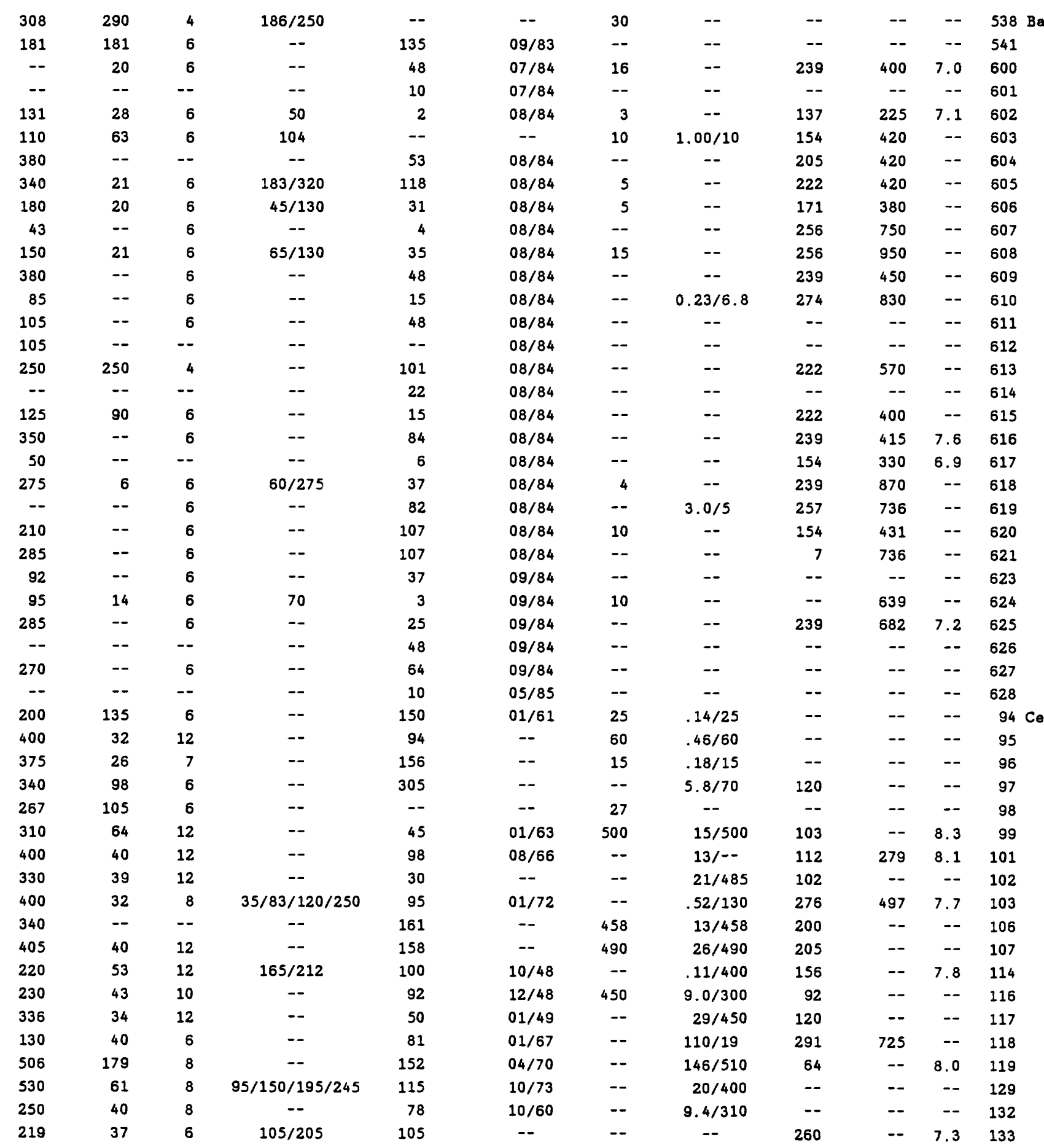




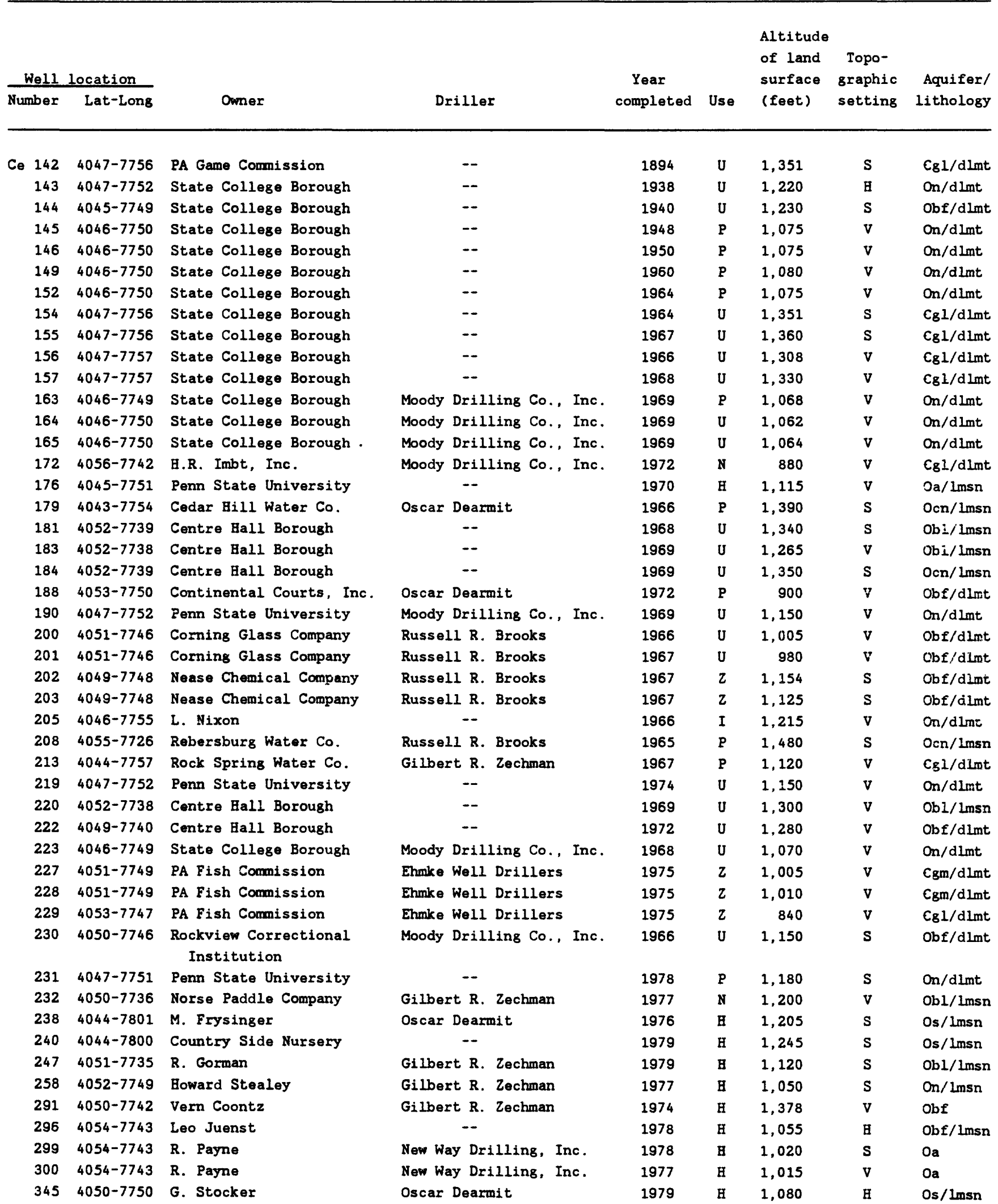




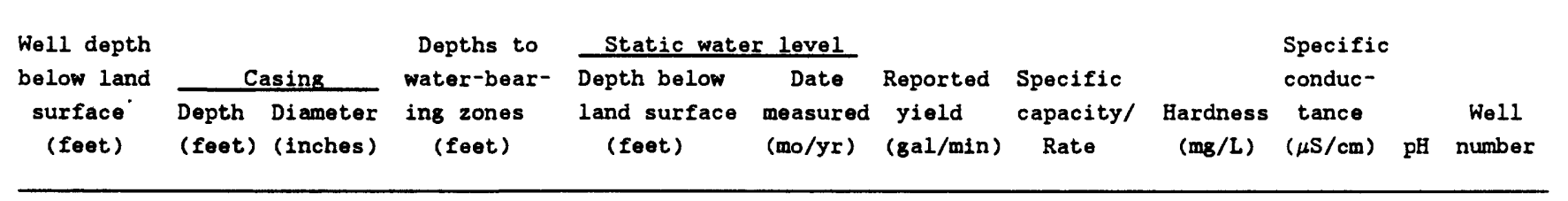

\begin{tabular}{|c|c|c|c|c|c|c|c|c|c|c|c|}
\hline 366 & 284 & 10 & $-\infty$ & 322 & -- & -- & $79 / 140$ & -- & -- & -- & $142 \mathrm{Ce}$ \\
\hline 603 & 10 & 16 & -- & 195 & $12 / 38$ & 575 & $19 / 575$ & 190 & -- & 7.6 & 143 \\
\hline 264 & 174 & 6 & -- & 25 & $06 / 40$ & 350 & $18 / 350$ & 78 & -- & -- & 144 \\
\hline 165 & 72 & 12 & 130 & 9 & -- & -- & $143 /--$ & 190 & -- & 8.0 & 145 \\
\hline 165 & 72 & 12 & -- & 11 & $11 / 50$ & -- & $600 / 200$ & 215 & -- & 7.6 & 146 \\
\hline 155 & 83 & 14 & -- & 13 & -- & -- & $236 / 650$ & 203 & 383 & 7.6 & 149 \\
\hline 142 & 82 & 12 & -- & 30 & $11 / 64$ & -- & $109 / 420$ & 208 & -- & 7.4 & 152 \\
\hline 453 & 286 & 8 & -- & 362 & -- & 350 & $136 / 350$ & -- & -- & -- & 154 \\
\hline 450 & 297 & 10 & -- & 404 & -- & 7 & $0.13 / 7$ & -- & -- & -- & 155 \\
\hline 500 & 359 & 10 & $340 / 362$ & 350 & -- & -- & $192 / 725$ & -- & -- & -- & 156 \\
\hline 505 & 434 & 16 & $379 / 400$ & 369 & $01 / 68$ & -- & $144 / 495$ & -- & -- & -- & 157 \\
\hline 228 & -- & -- & -- & 14 & $09 / 70$ & -- & $69 / 500$ & 206 & 372 & 7.7 & 163 \\
\hline 280 & -- & -- & -- & 8 & $09 / 70$ & -- & $152 / 500$ & 192 & 378 & 7.9 & 164 \\
\hline 260 & -- & -- & -- & 6 & $01 / 69$ & -- & $525 / 200$ & 194 & 382 & 7.9 & 165 \\
\hline 304 & 164 & 8 & -- & 25 & $07 / 72$ & -- & $9.4 / 980$ & -- & -- & -- & 172 \\
\hline 88 & 20 & 8 & $56 / 72 / 84$ & 52 & $05 / 70$ & -- & $.93 / 20$ & -- & -- & -- & 176 \\
\hline 185 & 22 & 6 & $19 / 103 / 175$ & 40 & $11 / 66$ & 10 & $.07 / 10$ & -- & -- & -- & 179 \\
\hline 300 & 110 & 6 & $220 / 235$ & 160 & $11 / 68$ & 2 & $.02 / 2$ & -- & -- & -- & 181 \\
\hline 338 & 74 & 6 & $160 / 235$ & 160 & $01 / 69$ & 30 & $.17 / 30$ & -- & -- & -- & 183 \\
\hline 350 & 80 & 6 & $220 / 260 / 320$ & 150 & $09 / 69$ & 7 & $.04 / 7$ & -- & -- & -- & 184 \\
\hline 40 & 29 & 6 & 30 & 10 & $01 / 72$ & 100 & $3.3 / 100$ & -- & -- & -- & 188 \\
\hline 275 & 165 & 12 & $20 / 60 / 100$ & 114 & $06 / 69$ & -- & $7.8 / 500$ & 216 & -- & 7.4 & 190 \\
\hline 175 & 36 & 6 & $140 / 168$ & 62 & $09 / 66$ & 15 & $.13 / 15$ & -- & -- & -- & 200 \\
\hline 250 & 25 & 6 & $133 / 196 / 242$ & 18 & $01 / 67$ & 10 & $.04 / 10$ & -- & -- & -- & 201 \\
\hline 150 & 74 & 6 & $99 / 126$ & 70 & $04 / 67$ & 6 & $.08 / 6$ & -- & -- & -- & 202 \\
\hline 70 & 38 & 6 & 50 & 14 & $04 / 67$ & 130 & $2.4 / 130$ & -- & -- & -- & 203 \\
\hline 325 & 217 & 6 & -- & 111 & $09 / 66$ & 56 & $.66 / 56$ & -- & -- & -- & 205 \\
\hline 350 & 72 & 6 & -- & 23 & $08 / 65$ & $=-$ & $.62 / 60$ & -- & -- & -- & 208 \\
\hline 322 & 60 & 8 & -- & 25 & $01 / 67$ & 100 & $10.0 / 100$ & 80 & -- & 7.9 & 213 \\
\hline 399 & 170 & 18 & $176 / 200 / 208$ & 118 & $01 / 74$ & -- & $11 / 600$ & -- & -- & -- & 219 \\
\hline 300 & 69 & 6 & $80 / 130$ & 190 & $05 / 69$ & 2 & $.02 / 2$ & -- & -- & -- & 220 \\
\hline 415 & 75 & 12 & -- & 152 & $02 / 72$ & 50 & $.25 / 50$ & 213 & -- & 7.7 & 222 \\
\hline 242 & 22 & 8 & $30 / 62 / 195$ & 12 & $01 / 69$ & -- & $110 / 500$ & 186 & -- & 7.8 & 223 \\
\hline 100 & 37 & 18 & -- & 5 & $05 / 75$ & 1,600 & $53 / 600$ & -- & -- & -- & 227 \\
\hline 100 & 24 & 18 & $41 / 85$ & 14 & $06 / 75$ & -- & $93 / 956$ & -- & -- & -- & 228 \\
\hline 125 & 36 & 16 & -- & 10 & $04 / 75$ & -- & $380 /--$ & -- & -- & -- & 229 \\
\hline 420 & 125 & 6 & -- & 105 & $01 / 68$ & 12 & -- & -- & -- & -- & 230 \\
\hline 405 & 118 & 8 & -- & 65 & $01 / 78$ & 600 & $40 / 600$ & -- & -- & -- & 231 \\
\hline 201 & 130 & 6 & $148 / 196$ & 70 & $05 / 77$ & 30 & -- & -- & -- & -- & 232 \\
\hline 125 & 100 & 6 & 120 & 6 & $07 / 80$ & 10 & -- & 137 & 290 & 7.7 & 238 \\
\hline 210 & 174 & 6 & 205 & 115 & $07 / 80$ & 40 & -- & 171 & 420 & 7.8 & 240 \\
\hline 201 & 40 & 6 & $74 / 190$ & 57 & $08 / 80$ & 35 & -- & 205 & 390 & 7.5 & 247 \\
\hline 326 & 130 & 6 & $262 / 320$ & 152 & $10 / 80$ & 7 & -- & 239 & 310 & 7.4 & 258 \\
\hline 326 & 60 & 6 & $97 / 280 / 320$ & 159 & $10 / 80$ & 5 & -- & 430 & 222 & 7.4 & 291 \\
\hline 210 & 25 & 6 & -- & 131 & $10 / 80$ & 7 & -- & 291 & 650 & 7.7 & 296 \\
\hline 180 & 106 & 6 & $156 / 174$ & 125 & $11 / 78$ & 10 & $1.4 / 5.5$ & 274 & 590 & -- & 299 \\
\hline 120 & 55 & 6 & 118 & 90 & $11 / 77$ & 10 & $.50 / 10$ & -- & -- & -- & 300 \\
\hline 230 & 168 & 6 & 220 & 190 & $11 / 80$ & 8 & -- & -- & -- & -- & 345 \\
\hline
\end{tabular}




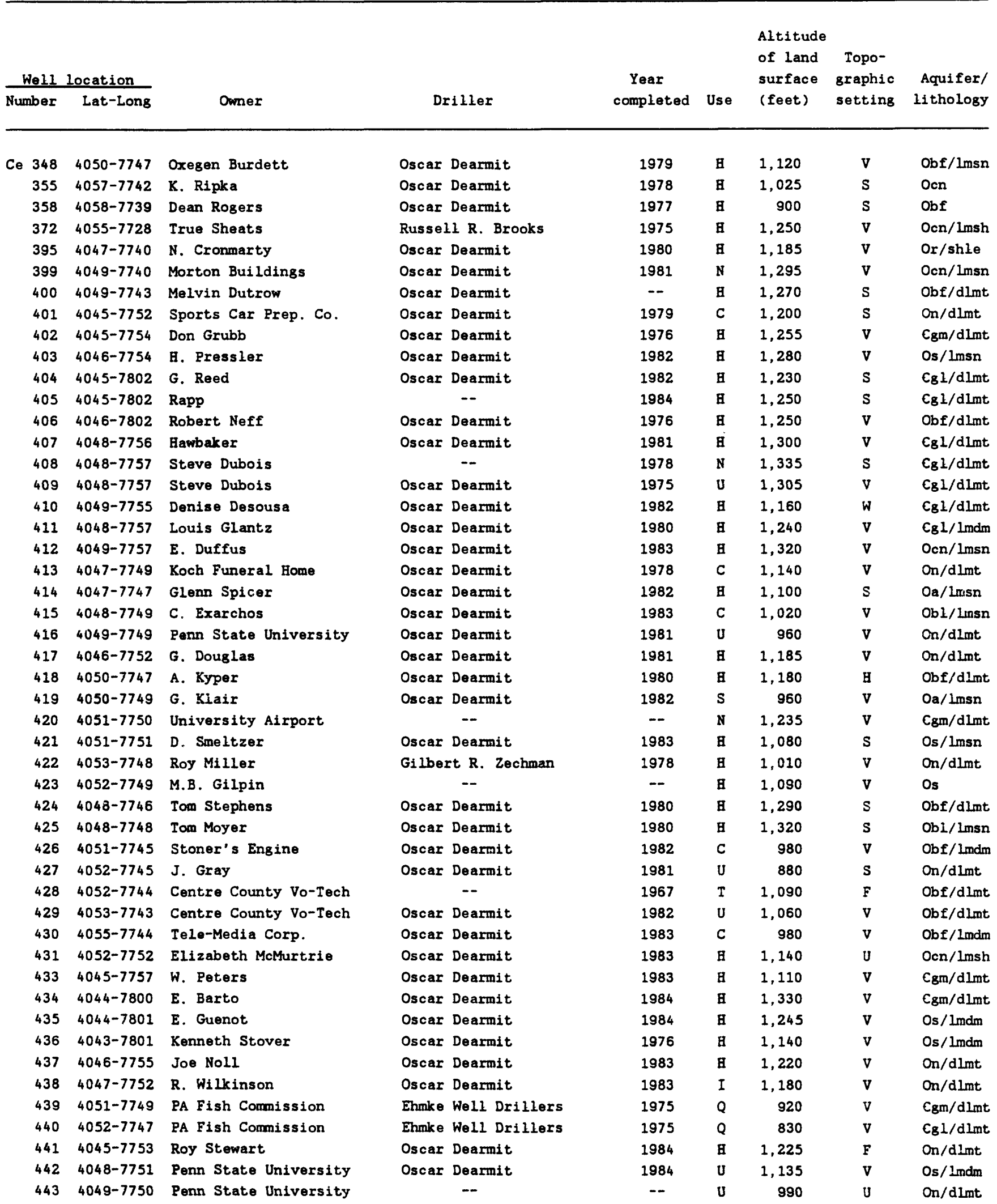


Well depth below land surface (feet)

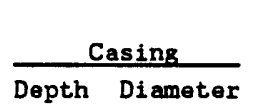
(feet) (inches)
Depths to Static water level

water-bear- Depth below Date Reported Specific

ing zones

land surface

measured yield

capacity/

(mo/yr) (gal/min) Rate
Specific

conduc-

Hardness tance

$(\mathrm{mg} / \mathrm{L}) \quad(\mu \mathrm{S} / \mathrm{cm})$ pH number

\begin{tabular}{|c|c|c|c|c|c|c|c|c|c|c|c|}
\hline 290 & 120 & 6 & 280 & 117 & $11 / 80$ & 20 & -- & 205 & 470 & -- & $348 \mathrm{Ce}$ \\
\hline 317 & 137 & 5 & 212 & 139 & $10 / 80$ & 15 & -- & 205 & 430 & -- & 355 \\
\hline 65 & 48 & 6 & 62 & 56 & $10 / 80$ & 30 & -- & 291 & 605 & 7.7 & 358 \\
\hline 101 & 48 & 6 & $62 / 84$ & 32 & $07 / 84$ & 20 & $0.30 / 20$ & 205 & 660 & 7.4 & 372 \\
\hline 126 & 40 & 6 & -- & 25 & $05 / 84$ & 25 & -- & 290 & 570 & 7.4 & 395 \\
\hline 175 & 60 & 6 & -- & 61 & $05 / 84$ & 12 & $.18 / 4.0$ & 410 & 778 & 7.2 & 399 \\
\hline 300 & 20 & 6 & -- & 134 & $05 / 84$ & -- & -- & 324 & 658 & 7.5 & 400 \\
\hline 146 & 111 & 6 & 136 & 87 & $06 / 84$ & 15 & -- & 325 & 848 & -- & 401 \\
\hline 210 & 100 & 6 & 210 & 95 & $06 / 84$ & 45 & $2.3 / 10$ & 308 & 975 & 7.6 & 402 \\
\hline 270 & 233 & 6 & 260 & 125 & $04 / 82$ & 30 & $.49 / 8$ & 171 & 328 & 8.0 & 403 \\
\hline 297 & 307 & 6 & 300 & 92 & $06 / 84$ & 150 & $7.0 / 7$ & 137 & 249 & 8.1 & 404 \\
\hline-- & -- & -- & -- & 109 & $06 / 84$ & -- & -- & -- & -- & -- & 405 \\
\hline 182 & 20 & 6 & 80 & 18 & $06 / 84$ & 3 & -- & 274 & 800 & -- & 406 \\
\hline 325 & 316 & 6 & 315 & 254 & $06 / 84$ & 60 & -- & 103 & 190 & 7.5 & 407 \\
\hline 325 & 45 & 6 & -- & 142 & $06 / 84$ & -- & -- & 137 & 308 & -- & 408 \\
\hline 65 & -- & -- & -- & 4 & $06 / 84$ & 13 & -- & -- & -- & -- & 409 \\
\hline 218 & 213 & 6 & 208 & 124 & $06 / 84$ & 60 & $9.7 / 8.9$ & 171 & 325 & -- & 410 \\
\hline 145 & 137 & 8 & 135 & -- & -- & 75 & -- & 205 & 430 & 7.6 & 411 \\
\hline 284 & 106 & 6 & 280 & 79 & $06 / 84$ & 6 & - & 103 & 308 & -- & 412 \\
\hline 165 & 51 & 6 & 160 & 86 & $06 / 84$ & 30 & -- & -- & -- & -- & 413 \\
\hline 125 & 100 & 6 & 115 & 84 & $06 / 84$ & 50 & $16 / 7.7$ & 257 & 590 & 7.7 & 414 \\
\hline 175 & 90 & 6 & 170 & 46 & $06 / 84$ & 55 & $1.5 / 55$ & 274 & 650 & 7.2 & 415 \\
\hline 209 & 71 & 10 & $53 / 61 / 82 / 102$ & 25 & $06 / 84$ & 1,700 & $137 / 100$ & 68 & 326 & 7.4 & 416 \\
\hline 300 & 248 & 6 & 290 & 81 & $06 / 84$ & 80 & -- & 205 & 420 & 7.1 & 417 \\
\hline 300 & 315 & 6 & 290 & 162 & $06 / 84$ & 30 & $11 / 4.4$ & 188 & 635 & 6.6 & 418 \\
\hline 110 & 100 & 6 & 100 & 19 & $06 / 84$ & 120 & -- & 274 & 658 & 6.7 & 419 \\
\hline 299 & -- & -- & -- & 234 & $06 / 84$ & -- & -- & 205 & 285 & -- & 420 \\
\hline 173 & 151 & 6 & 163 & 129 & $06 / 84$ & 15 & -- & 205 & 475 & -- & 421 \\
\hline 451 & 247 & 6 & $405 / 440$ & 86 & $06 / 84$ & 5 & -- & 239 & 475 & 6.6 & 422 \\
\hline-- & -- & -- & -- & 178 & $06 / 84$ & -- & -- & 188 & 529 & 6.9 & 423 \\
\hline 105 & 57 & 6 & 95 & 60 & $06 / 84$ & 6 & -- & 222 & 466 & 7.7 & 424 \\
\hline 229 & 42 & 6 & 219 & 73 & $06 / 84$ & 5 & -- & 222 & -- & -- & 425 \\
\hline 166 & 110 & -- & 156 & 41 & $06 / 84$ & 60 & -- & 291 & 628 & -- & 426 \\
\hline 250 & 86 & -- & 240 & 138 & $06 / 84$ & 50 & -- & -- & -- & -- & 427 \\
\hline 225 & 79 & 6 & $175 / 197 / 202$ & 133 & $06 / 84$ & 15 & -- & 274 & 608 & -- & 428 \\
\hline 150 & 140 & 6 & 140 & 92 & $06 / 84$ & 30 & -- & -- & -- & -- & 429 \\
\hline 600 & 61 & 6 & 590 & 14 & $06 / 84$ & 1 & -- & -- & -- & -- & 430 \\
\hline 575 & 25 & 6 & 565 & 22 & $06 / 84$ & -- & -- & 120 & 860 & -- & 431 \\
\hline 60 & 51 & 6 & 50 & 21 & $06 / 84$ & 60 & - & 137 & 360 & 7.6 & 433 \\
\hline 300 & 294 & 6 & -- & 195 & $06 / 84$ & 30 & -- & 120 & 515 & 7.2 & 434 \\
\hline 181 & 158 & 6 & $156 / 162 / 180$ & 123 & $06 / 84$ & 30 & -- & -- & -- & -- & 435 \\
\hline 97 & 91 & 6 & $50 / 91$ & 76 & $06 / 84$ & -- & -- & 137 & 660 & 7.0 & 436 \\
\hline 525 & 111 & 6 & 515 & 82 & $06 / 84$ & 3 & -- & 291 & 685 & 7.5 & 437 \\
\hline 150 & 106 & 6 & 146 & 60 & $06 / 84$ & 6 & $.33 / 8.7$ & 291 & 610 & 7.9 & 438 \\
\hline 125 & 36 & 16 & $42 / 74 / 104$ & 19 & $06 / 84$ & -- & $380 /--$ & 171 & 773 & -- & 439 \\
\hline 100 & 37 & 18 & $45 / 70$ & 84 & $06 / 84$ & -- & $53 / 600$ & 120 & 560 & 7.3 & 440 \\
\hline 225 & 154 & 6 & $212 / 224$ & 90 & $06 / 84$ & 60 & -- & -- & -- & -- & 441 \\
\hline 135 & 43 & 6 & 110 & 30 & $06 / 84$ & 6 & -- & -- & -- & -- & 442 \\
\hline 405 & 405 & 8 & -- & 53 & $06 / 84$ & 800 & - & 309 & -- & 7.5 & 443 \\
\hline
\end{tabular}




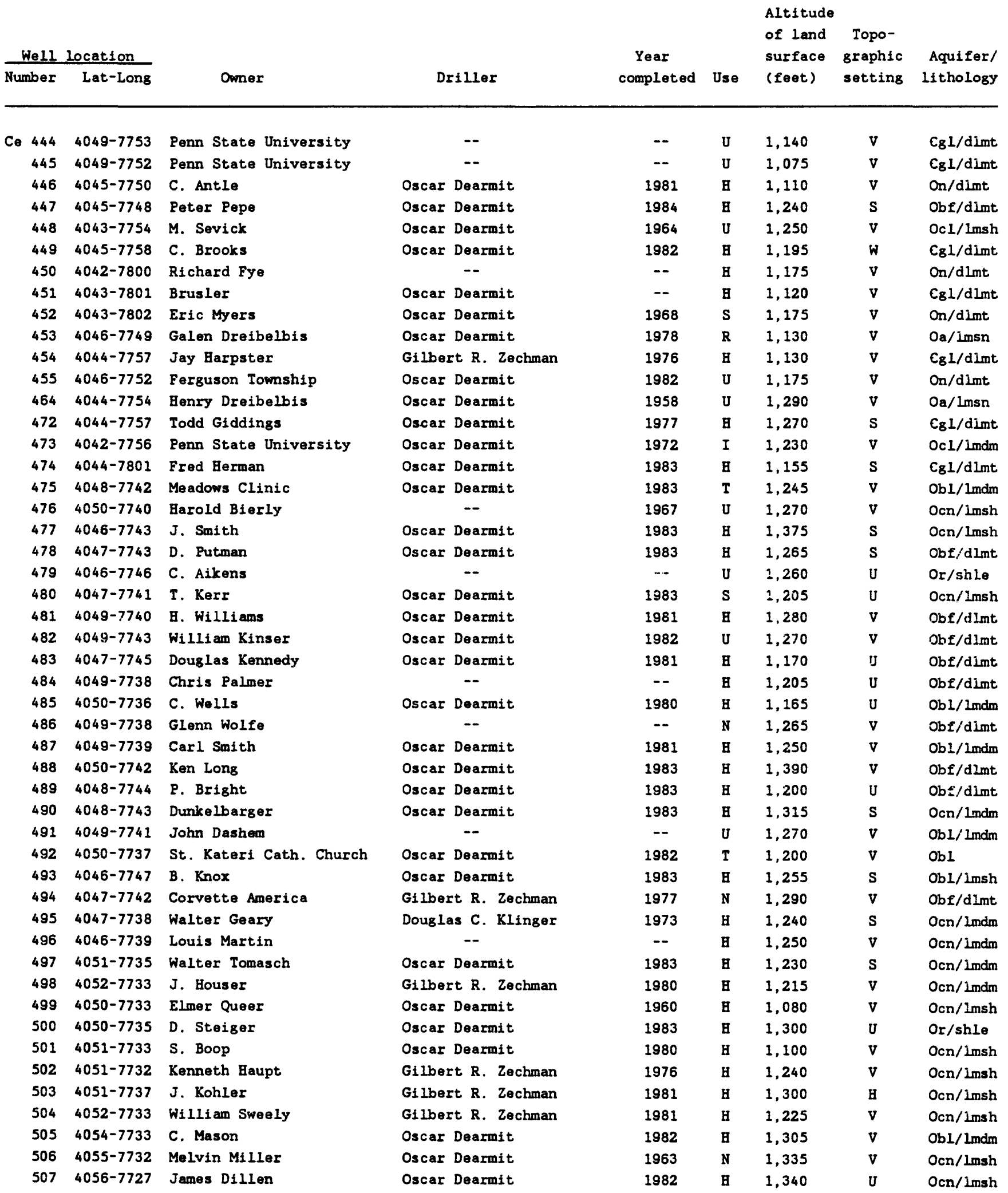


Well depth

surface

(feet)

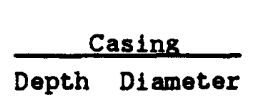

(feet) (Inches)
Depths to Static water level

water-bear- Depth below Date Reported Specific

ing zones land surface measured yield

capacity/

(mo/yr) (gal/min) Rate
Specific

conduc-

Hardness tance

$(\mathrm{mg} / \mathrm{L}) \quad(\mu \mathrm{S} / \mathrm{cm})$ pH number

\begin{tabular}{|c|c|c|c|c|c|c|c|c|c|c|c|}
\hline 289 & -- & 4 & -- & 97 & $06 / 84$ & -- & -- & 70 & -- & 8.4 & $444 \mathrm{Ce}$ \\
\hline 200 & 89 & 6 & -- & 61 & $06 / 84$ & -- & -- & 110 & -- & 7.6 & 445 \\
\hline 150 & 128 & 6 & 140 & 46 & $06 / 84$ & 70 & -- & 137 & 785 & 7.1 & 446 \\
\hline 150 & 127 & 6 & 140 & 85 & $06 / 84$ & 10 & $0.2 / 4$ & -- & 538 & 7.1 & 447 \\
\hline 50 & 50 & 6 & -- & 6 & $06 / 84$ & -- & -- & -- & -- & -- & 448 \\
\hline 365 & -- & 6 & -- & 190 & $06 / 84$ & -- & -- & 86 & 300 & 7.2 & 449 \\
\hline 115 & -- & -- & -- & 79 & $06 / 84$ & -- & -- & 222 & 398 & 6.8 & 450 \\
\hline 23 & -- & -- & -- & 14 & $07 / 84$ & -- & -- & 274 & 720 & -- & 451 \\
\hline 330 & -- & -- & -- & 111 & $07 / 84$ & -- & -- & 154 & 790 & 7.2 & 452 \\
\hline 95 & 80 & 6 & 90 & 38 & $06 / 84$ & 80 & -- & 188 & 622 & -- & 453 \\
\hline 160 & 125 & 6 & 145 & 1 & $06 / 84$ & 50 & -- & -- & -- & -- & 454 \\
\hline 110 & 49 & 6 & 100 & 82 & $06 / 84$ & -- & -- & -- & -- & -- & 455 \\
\hline 217 & 25 & 6 & -- & 71 & $06 / 84$ & -- & -- & -- & -- & -- & 464 \\
\hline 285 & 82 & 6 & $180 / 282$ & 154 & $06 / 84$ & 15 & -- & 68 & 155 & -- & 472 \\
\hline-- & -- & -- & -- & 35 & $07 / 84$ & -- & -- & 205 & 550 & -- & 473 \\
\hline 64 & 54 & 6 & 60 & 22 & $07 / 84$ & 10 & -- & 171 & 710 & 7.3 & 474 \\
\hline 225 & 141 & 6 & $197 / 224$ & 73 & $07 / 84$ & -- & $7.0 / 60$ & -- & -- & -- & 475 \\
\hline 179 & 15 & -- & 93 & 91 & $07 / 84$ & 32 & -- & -- & -- & -- & 476 \\
\hline 158 & 135 & 6 & 150 & 75 & $07 / 84$ & 12 & -- & 137 & 495 & -- & 477 \\
\hline 230 & 57 & 6 & 220 & 86 & $07 / 84$ & 60 & -- & 256 & 600 & 7.6 & 478 \\
\hline 35 & -- & -- & -- & 3 & $07 / 84$ & -- & -- & -- & -- & -- & 479 \\
\hline 250 & 196 & 6 & $200 / 240$ & 90 & $07 / 84$ & 6 & -- & 120 & 330 & -- & 480 \\
\hline 175 & 1,562 & 6 & 165 & 57 & $07 / 84$ & 60 & -- & 222 & 632 & 7.2 & 481 \\
\hline 250 & 68 & 6 & 240 & 90 & $07 / 84$ & 120 & -- & -- & -- & -- & 482 \\
\hline 150 & 86 & 6 & 140 & 57 & $07 / 84$ & 17 & -- & -- & -- & -- & 483 \\
\hline-- & -- & -- & -- & 99 & $07 / 84$ & -- & -- & 222 & 632 & 7.1 & 484 \\
\hline 150 & 95 & 6 & 140 & 60 & $07 / 84$ & 8 & $.58 / 9.9$ & 222 & 682 & -- & 485 \\
\hline 180 & -- & -- & -- & 80 & $07 / 84$ & -- & -- & 359 & 850 & 7.3 & 486 \\
\hline 150 & 60 & 6 & 140 & 24 & $07 / 84$ & 30 & $.96 / 6$ & 256 & 783 & -- & 487 \\
\hline 332 & 225 & 6 & 250 & 80 & $07 / 84$ & 15 & -- & 171 & 448 & 7.3 & 488 \\
\hline 168 & 101 & 6 & 158 & 35 & $07 / 84$ & 8 & -- & 205 & 500 & 7.1 & 489 \\
\hline 265 & 50 & 6 & -- & 34 & $07 / 84$ & 5 & -- & 256 & 527 & 7.3 & 490 \\
\hline 100 & -- & -- & -- & 62 & $07 / 84$ & -- & -- & -- & -- & -- & 491 \\
\hline 183 & 175 & 6 & 173 & 99 & $07 / 84$ & 60 & -- & -- & -- & -- & 492 \\
\hline 450 & 38 & 6 & 440 & 145 & $07 / 84$ & 20 & -- & 137 & 441 & 7.0 & 493 \\
\hline 201 & 106 & 6 & $122 / 200$ & 23 & $07 / 84$ & 25 & $.95 / 9$ & 274 & 673 & -- & 494 \\
\hline 115 & -- & -- & -- & 45 & $07 / 84$ & 30 & -- & 256 & -- & 6.9 & 495 \\
\hline-- & -- & -- & -- & 25 & $07 / 84$ & -- & -- & 153 & 570 & -- & 496 \\
\hline 450 & 100 & & $252 / 274 / 343 / 447$ & 144 & $07 / 84$ & 7 & -- & -- & -- & -- & 497 \\
\hline 101 & 40 & 6 & $81 / 89$ & 11 & $07 / 84$ & 9 & $.09 / 4.5$ & 239 & 682 & -- & 498 \\
\hline 127 & 20 & 4 & -- & 7 & $07 / 84$ & -- & -- & 239 & 660 & -- & 499 \\
\hline 298 & 20 & 6 & 240 & -- & -- & -- & -- & 68 & 315 & -- & 500 \\
\hline 251 & 40 & 6 & $140 / 226$ & 11 & $07 / 84$ & 3 & -- & 222 & 723 & -- & 501 \\
\hline 251 & 41 & 6 & $88 / 242$ & 66 & $07 / 84$ & 10 & -- & 274 & 830 & 7.5 & 502 \\
\hline 500 & 40 & 6 & $322 / 409 / 465 / 484$ & 178 & $07 / 84$ & 6 & -- & 188 & 880 & 7.3 & 503 \\
\hline 128 & 40 & 6 & -- & 39 & $07 / 84$ & 20 & -- & 188 & 683 & 7.3 & 504 \\
\hline 250 & 246 & 6 & 240 & 132 & $07 / 84$ & 60 & -- & 239 & -- & 7.6 & 505 \\
\hline 525 & 12 & 6 & -- & 46 & $07 / 84$ & -- & -- & 222 & 660 & -- & 506 \\
\hline 175 & 74 & 6 & 165 & 104 & $07 / 84$ & 30 & -- & 120 & 550 & -- & 507 \\
\hline
\end{tabular}




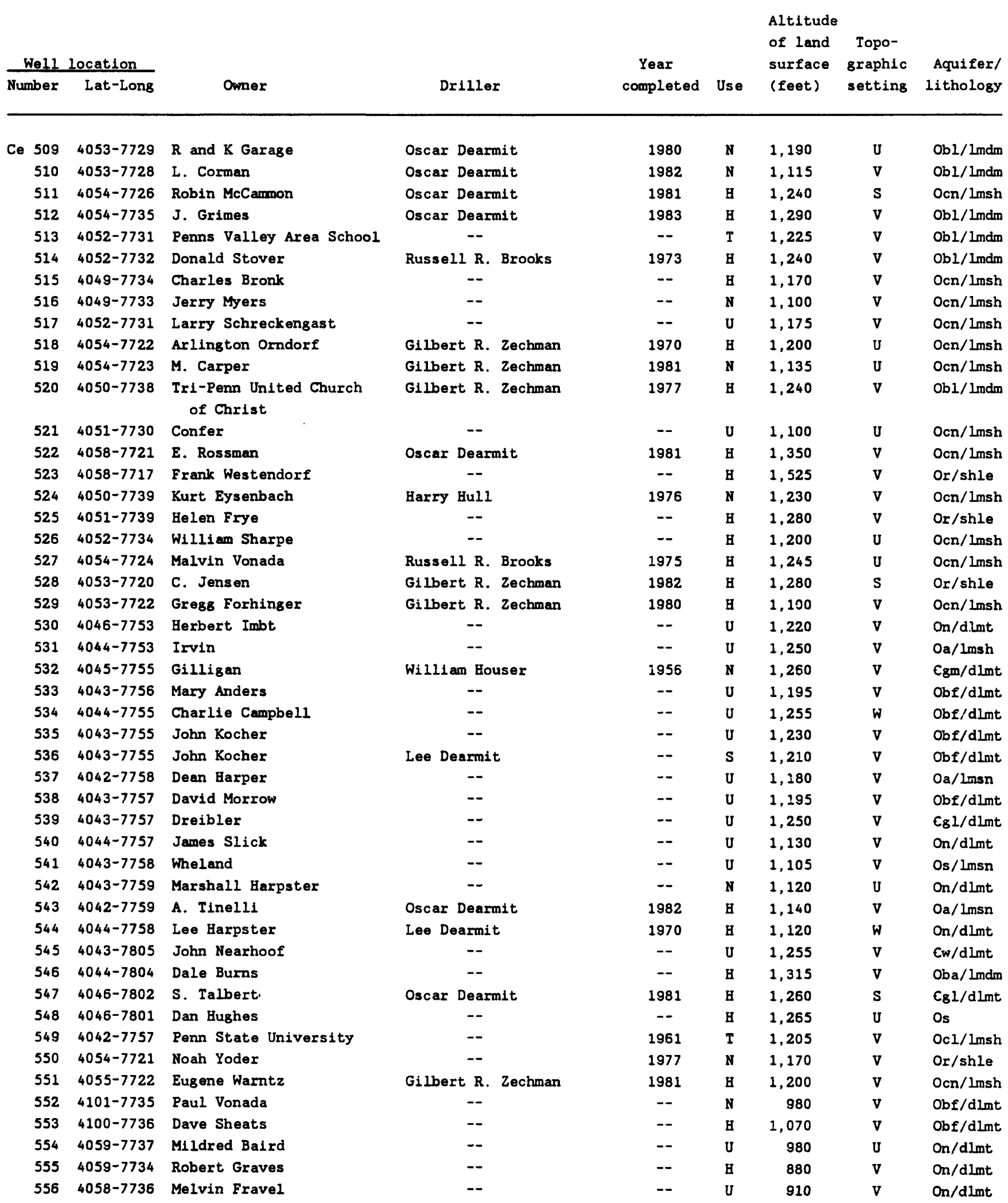


Well depth

below land

surface

(feet)
Depths to Static water level

water-bear- Depth below Date Reported Specific

Casing

Depth Diameter ing zones

(feet) land surface measured yield

(feet) (mo/yr) (gal/min) capacity/

conduc-

Rate (mg/L) $(\mu \mathrm{S} / \mathrm{cm}) \quad \mathrm{pH}$ number

\begin{tabular}{|c|c|c|c|c|c|c|c|c|c|c|c|}
\hline 165 & 128 & 6 & 155 & 87 & $07 / 84$ & 20 & $6.6 / 7.9$ & 239 & 620 & -- & 509 \\
\hline 272 & 130 & 6 & 262 & 20 & $07 / 84$ & 8 & -- & 256 & 705 & -- & 510 \\
\hline 250 & 43 & 6 & 240 & 32 & $07 / 84$ & 4 & -- & -- & -- & -- & 511 \\
\hline 167 & 149 & 6 & 165 & 81 & $07 / 84$ & 6 & $0.26 / 7.0$ & 171 & 560 & -- & 512 \\
\hline 500 & -- & 8 & -- & -- & -- & 50 & -- & 188 & 878 & -- & 513 \\
\hline 225 & 60 & 6 & -- & 92 & $07 / 84$ & 60 & -- & 205 & 878 & 6.8 & 514 \\
\hline-- & -- & -- & -- & 2 & $07 / 84$ & -- & -- & 205 & 808 & -- & 515 \\
\hline-- & -- & -- & -- & 7 & $07 / 84$ & -- & -- & 239 & 605 & -- & 516 \\
\hline-- & -- & -- & - & 2 & $07 / 84$ & -- & -- & -- & -- & -- & 517 \\
\hline 494 & 41 & 6 & $25 / 170 / 450$ & 65 & $07 / 84$ & 5 & $.15 / 9.8$ & 222 & 665 & 6.7 & 518 \\
\hline 85 & 40 & 6 & $54 / 60 / 73$ & 8 & $07 / 84$ & 12 & -- & 239 & 735 & -- & 519 \\
\hline 401 & 40 & 6 & $170 / 370$ & 105 & $07 / 84$ & 6 & -- & 274 & -- & -- & 520 \\
\hline 15 & -- & -- & $-\infty$ & 11 & $07 / 84$ & -- & -- & -- & -- & -- & 521 \\
\hline 198 & 43 & 6 & 188 & 21 & $07 / 84$ & 10 & - & 239 & 370 & -- & 522 \\
\hline 145 & -- & - & -- & 32 & $07 / 84$ & - & - & -- & 120 & -- & 523 \\
\hline 210 & 20 & 6 & -- & 66 & $07 / 84$ & 30 & -- & 256 & 450 & - & 524 \\
\hline 95 & -- & -- & -- & 18 & $07 / 84$ & -- & -- & 222 & 400 & 6.9 & 525 \\
\hline 85 & -- & -- & -- & 11 & $07 / 84$ & -- & -- & 256 & 350 & 7.2 & 526 \\
\hline 152 & 28 & 6 & $75 / 141 / 150$ & 40 & $07 / 84$ & 12 & $.11 / 12$ & 188 & 375 & - & 527 \\
\hline 101 & 60 & 6 & $64 / 74 / 89$ & 21 & $07 / 84$ & 13 & -- & 34 & 100 & 8.0 & 528 \\
\hline 110 & 52 & 6 & 58 & 43 & $07 / 84$ & 45 & -- & -- & - & $-\infty$ & 529 \\
\hline-- & -- & -- & $-\infty$ & 95 & $07 / 84$ & -- & -- & -- & - & -- & 530 \\
\hline 187 & 50 & 6 & -- & 52 & $07 / 84$ & -- & -- & - & $-\infty$ & - & 531 \\
\hline 205 & 50 & 6 & -- & 97 & $07 / 84$ & - & -- & 154 & 310 & -- & 532 \\
\hline 135 & - & 6 & - & 17 & $07 / 84$ & -- & -- & -- & -- & -- & 533 \\
\hline 75 & $-\infty$ & - & -- & 37 & $07 / 84$ & -- & -- & - & -- & -- & 534 \\
\hline 160 & -- & -- & - & 32 & $07 / 84$ & $\cdots$ & -- & -- & - & - & 535 \\
\hline 112 & -- & 6 & $-\infty$ & 12 & $07 / 84$ & -- & -- & 291 & 670 & -- & 536 \\
\hline 105 & -- & -- & - & 32 & $07 / 84$ & -- & - & -- & -- & -- & 537 \\
\hline-- & -- & -- & -- & 8 & $07 / 84$ & -- & - & -- & -- & $-\infty$ & 538 \\
\hline-- & -- & -- & - & 1 & $07 / 84$ & - & -- & -- & -- & -- & 539 \\
\hline-- & - & - & -- & 9 & $07 / 84$ & -- & - & -- & -- & -- & 540 \\
\hline 17 & -- & -- & -- & 4 & $07 / 84$ & - & - & 120 & 275 & -- & 541 \\
\hline 74 & -- & -- & $-\infty$ & 21 & $07 / 84$ & 25 & -- & 205 & 385 & 7.7 & 542 \\
\hline 422 & 14 & 6 & 412 & 14 & $07 / 84$ & 35 & - & 120 & 240 & 7.1 & 543 \\
\hline 65 & 20 & 6 & -- & 13 & $07 / 84$ & 45 & $16 / 30.9$ & 274 & 450 & 7.5 & 544 \\
\hline 14 & -- & -- & -- & 8 & $07 / 84$ & -- & -- & - & -- & -- & 545 \\
\hline 100 & 21 & 6 & - & 23 & $07 / 84$ & -- & - & 239 & 455 & - & 546 \\
\hline 215 & 110 & 6 & 205 & 69 & $07 / 84$ & 200 & -- & 137 & 245 & -- & 547 \\
\hline 170 & -- & -- & -- & 58 & $07 / 84$ & -- & -- & 120 & 230 & -- & 548 \\
\hline 200 & -- & -- & -- & 52 & $07 / 84$ & 25 & - & 291 & 660 & -- & 549 \\
\hline 80 & 75 & 6 & -- & 16 & $07 / 84$ & -- & - & 103 & 265 & -- & 550 \\
\hline 140 & 80 & 6 & 140 & 7 & $07 / 84$ & 30 & -- & 154 & 370 & 7.6 & 551 \\
\hline-- & -- & - & -- & 69 & $08 / 84$ & -- & -- & 256 & 730 & - & 552 \\
\hline 300 & - & 6 & -- & 14 & $08 / 84$ & 2 & -- & 308 & 710 & -- & 553 \\
\hline- & -- & -- & -- & 1 & $08 / 84$ & -- & -- & -- & -- & -- & 554 \\
\hline 52 & -- & -- & - & 14 & $08 / 84$ & - & $10 / 3.7$ & 154 & 320 & -- & 555 \\
\hline 35 & -- & - & -- & 8 & $08 / 84$ & -- & $\cdots$ & 85 & 190 & $-\infty$ & 556 \\
\hline
\end{tabular}




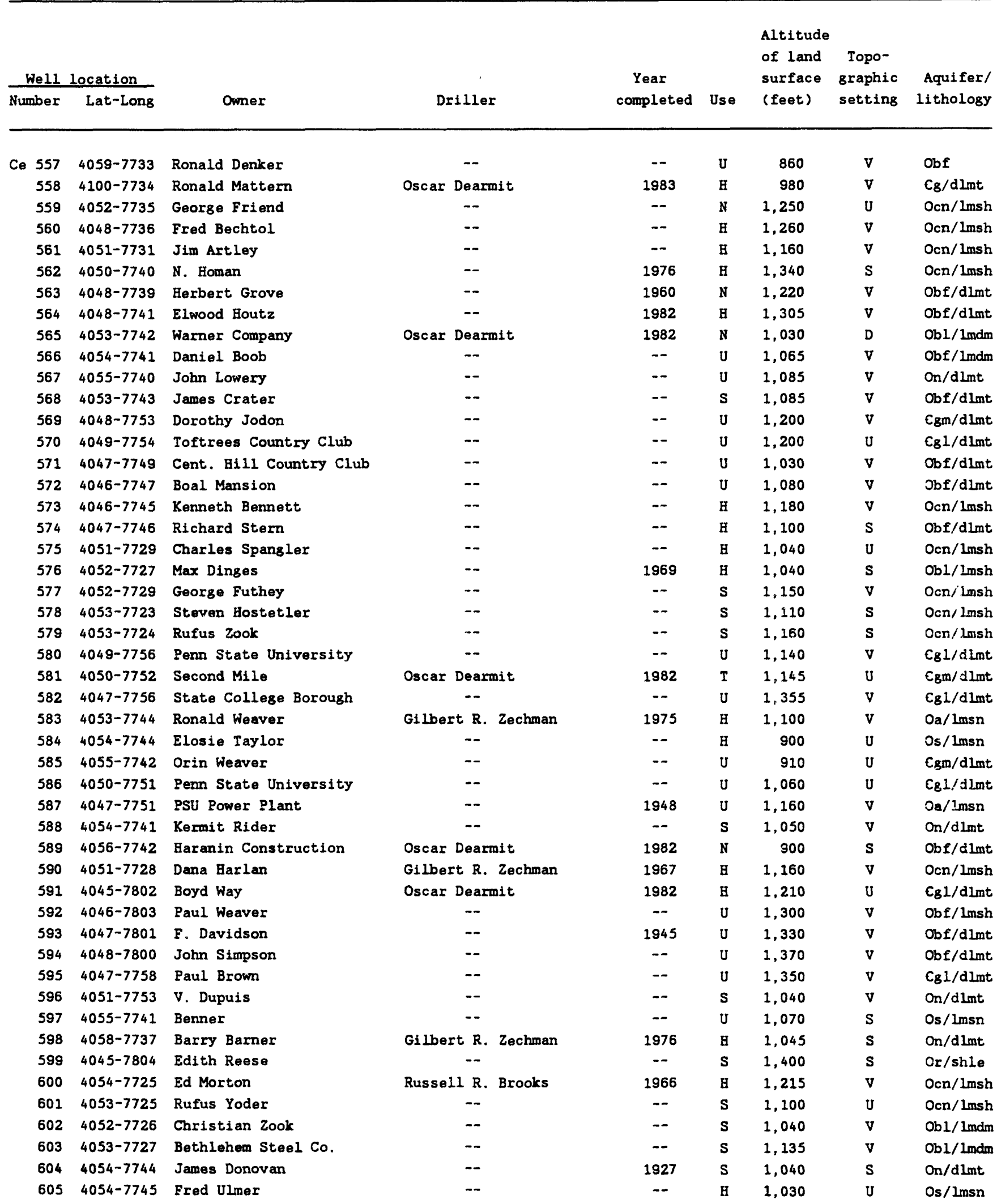




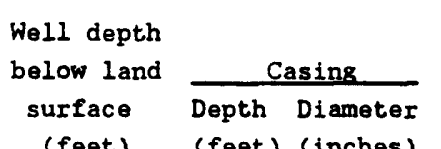

(feet)
Depths to

Depth below Date Reported Specific

land surface measured yield
Specific

conduc- capacity

(feet) (feet) (mo/yr) (gal/min) Rate (mg/L) ( $\mu S / \mathrm{cm}$ ) $\mathrm{pH}$ number

(feet) (feet) (mo/yr) (gal/min) Rate (mg/L) ( $\mu S / \mathrm{cm}$ ) $\mathrm{pH}$ number

Well

\begin{tabular}{|c|c|c|c|c|c|c|c|c|c|c|c|}
\hline 60 & -- & -- & - & 9 & $08 / 84$ & -- & -- & -- & -- & -- & $557 \mathrm{Ce}$ \\
\hline 298 & 140 & 6 & 288 & 83 & $08 / 84$ & 2 & -- & 58 & 170 & -- & 558 \\
\hline-- & -- & 6 & -- & & -- & -- & -- & 222 & 670 & -- & 559 \\
\hline 73 & 60 & 6 & -- & 10 & $08 / 84$ & -- & -- & 68 & 150 & -- & 560 \\
\hline 35 & -- & -- & -- & 10 & $08 / 84$ & -- & -- & 274 & 660 & -- & 561 \\
\hline 342 & 40 & 6 & $50 / 320$ & 17 & $08 / 84$ & 2 & -- & 205 & 450 & -- & 562 \\
\hline 205 & 20 & 6 & - & 38 & $08 / 84$ & -- & -- & -- & 460 & 2.0 & 563 \\
\hline 150 & 95 & 6 & -- & 40 & $08 / 84$ & -- & -- & 188 & 330 & -- & 564 \\
\hline 225 & 155 & 6 & $170 / 200 / 215$ & 54 & $08 / 84$ & 60 & -- & 256 & 620 & -- & 565 \\
\hline-- & -- & -- & -- & 8 & $08 / 84$ & -- & -- & -- & -- & -- & 566 \\
\hline-- & -- & -- & -- & 2 & $08 / 84$ & -- & -- & -- & -- & -- & 567 \\
\hline 256 & -- & 6 & -- & 40 & $08 / 84$ & -- & -- & 308 & 955 & 7.5 & 568 \\
\hline-- & -- & 6 & -- & 98 & $09 / 84$ & -- & -- & -- & -- & -- & 569 \\
\hline 280 & - & 8 & -- & 23 & $09 / 84$ & -- & -- & -- & -- & -- & 570 \\
\hline 300 & - & 10 & -- & 3 & $09 / 84$ & -- & -- & - & -- & -- & 571 \\
\hline-- & -- & -- & -- & 16 & $09 / 84$ & -- & -- & -- & -- & -- & 572 \\
\hline 105 & -- & 6 & -- & 12 & $09 / 84$ & -- & -- & 257 & 665 & 7.3 & 573 \\
\hline-- & -- & 6 & -- & 29 & $09 / 84$ & -- & -- & 205 & 573 & 7.4 & 574 \\
\hline 13 & -- & -- & -- & 9 & $10 / 84$ & -- & - & 120 & 593 & -- & 575 \\
\hline 75 & 50 & 6 & -- & 23 & $10 / 84$ & 25 & -- & 171 & 539 & -- & 576 \\
\hline-- & -- & 6 & -- & 17 & $10 / 84$ & -- & - & 222 & 763 & 7.1 & 577 \\
\hline 52 & 20 & 6 & -- & 19 & $10 / 84$ & 20 & -- & 205 & 647 & -- & 578 \\
\hline 100 & -- & 6 & -- & 52 & $10 / 84$ & -- & -- & 188 & 638 & 7.1 & 579 \\
\hline 744 & 450 & 6 & -- & 40 & $10 / 84$ & -- & -- & -- & -- & -- & 580 \\
\hline 220 & 198 & 6 & 210 & 149 & $10 / 84$ & 60 & -- & -- & -- & -- & 581 \\
\hline- & -- & 6 & -- & 306 & $10 / 84$ & -- & -- & -- & -- & -- & 582 \\
\hline 425 & 69 & 6 & $212 / 300 / 345$ & 202 & $10 / 84$ & 6 & -- & 256 & 946 & -- & 583 \\
\hline 101 & - & 6 & -- & 30 & $10 / 84$ & -- & -- & 205 & 539 & -- & 584 \\
\hline 100 & -- & 6 & -- & 12 & $10 / 84$ & -- & -- & -- & -- & -- & 585 \\
\hline 150 & -- & -- & -- & 51 & $10 / 84$ & -- & -- & -- & -- & -- & 586 \\
\hline 357 & -- & 8 & -- & 154 & $10 / 84$ & 700 & -- & -- & -- & -- & 587 \\
\hline 170 & -- & 6 & -- & 37 & $10 / 84$ & -- & -- & 274 & -- & 7.0 & 588 \\
\hline 100 & 81 & 6 & -- & 34 & $10 / 84$ & 60 & -- & 188 & 610 & -- & 589 \\
\hline 201 & 40 & 6 & 153 & 153 & $10 / 84$ & 3 & -- & 222 & 682 & 7.3 & 590 \\
\hline 123 & 116 & 6 & 113 & 35 & $09 / 84$ & 60 & -- & 103 & 363 & 7.9 & 591 \\
\hline-- & -- & 6 & -- & 16 & $09 / 84$ & -- & -- & -- & - & -- & 592 \\
\hline 37 & -- & 6 & -- & 13 & $09 / 84$ & 50 & -- & -- & -- & -- & 593 \\
\hline-- & -- & -- & - & 20 & $10 / 84$ & -- & -- & -- & -- & -- & 594 \\
\hline-- & -- & -- & -- & 7 & $10 / 84$ & -- & -- & -- & -- & -- & 595 \\
\hline 74 & 43 & 6 & -- & 15 & $10 / 84$ & -- & -- & 154 & 460 & 7.7 & 596 \\
\hline 91 & -- & 6 & - & 86 & $10 / 84$ & -- & -- & -- & -- & -- & 597 \\
\hline 326 & 75 & 6 & $200 / 309$ & 75 & $10 / 84$ & 60 & -- & 205 & 647 & 7.5 & 598 \\
\hline 60 & -- & 6 & -- & 19 & $10 / 84$ & -- & -- & 68 & 228 & -- & 599 \\
\hline 245 & 245 & 6 & -- & 151 & $10 / 84$ & -- & -- & 171 & 638 & 6.9 & 600 \\
\hline 71 & -- & 6 & -- & 7 & $10 / 84$ & -- & -- & 222 & 557 & -- & 601 \\
\hline 43 & -- & 6 & -- & 11 & $10 / 84$ & -- & -- & 137 & 430 & 7.4 & 602 \\
\hline-- & -- & 6 & -- & 87 & $10 / 84$ & -- & -- & 291 & 910 & -- & 603 \\
\hline 265 & 225 & 6 & -- & 84 & $10 / 84$ & -- & -- & 410 & 953 & 7.4 & 604 \\
\hline 300 & -- & 6 & -- & 187 & $10 / 84$ & -- & - & 308 & 830 & -- & 605 \\
\hline
\end{tabular}




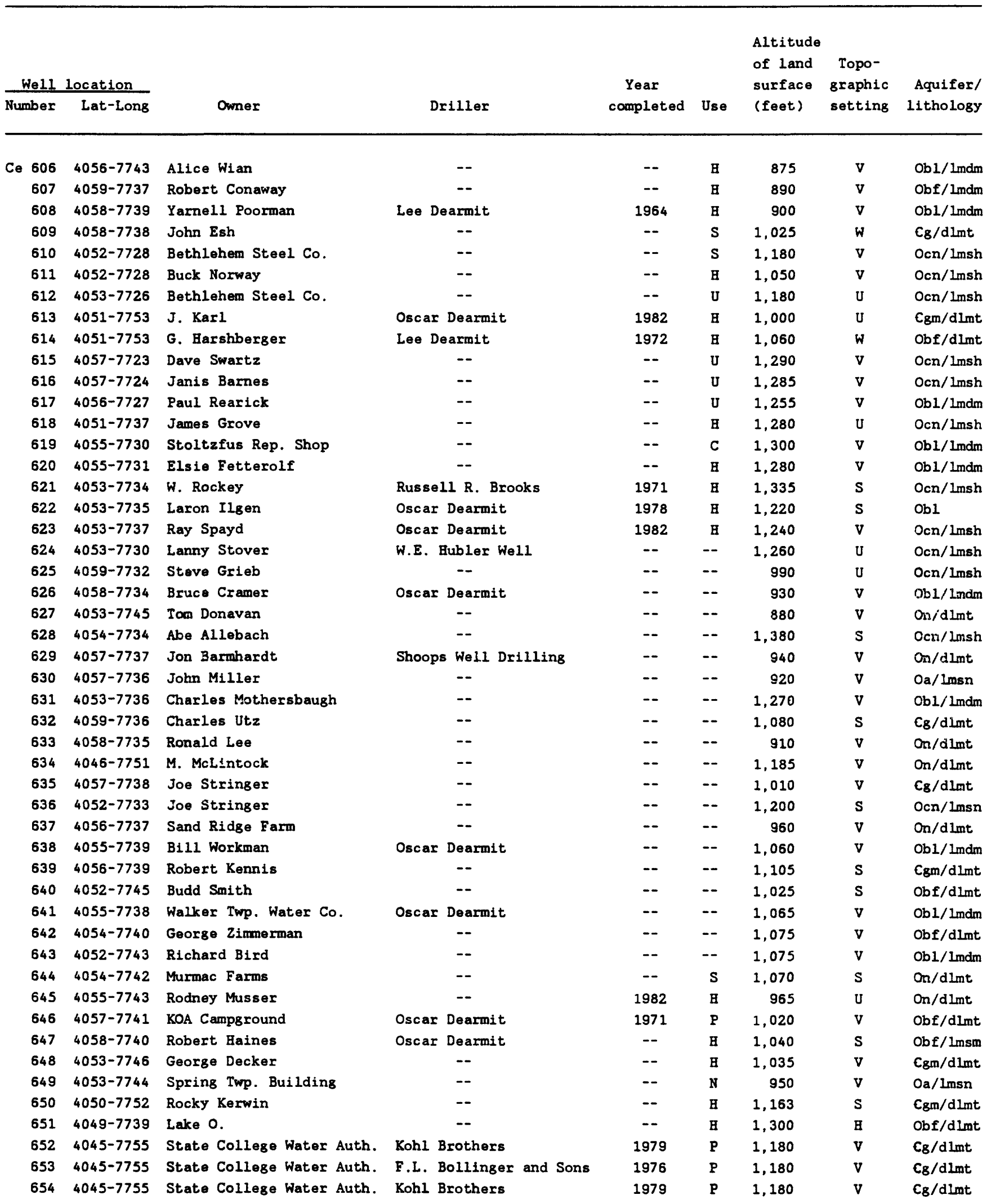




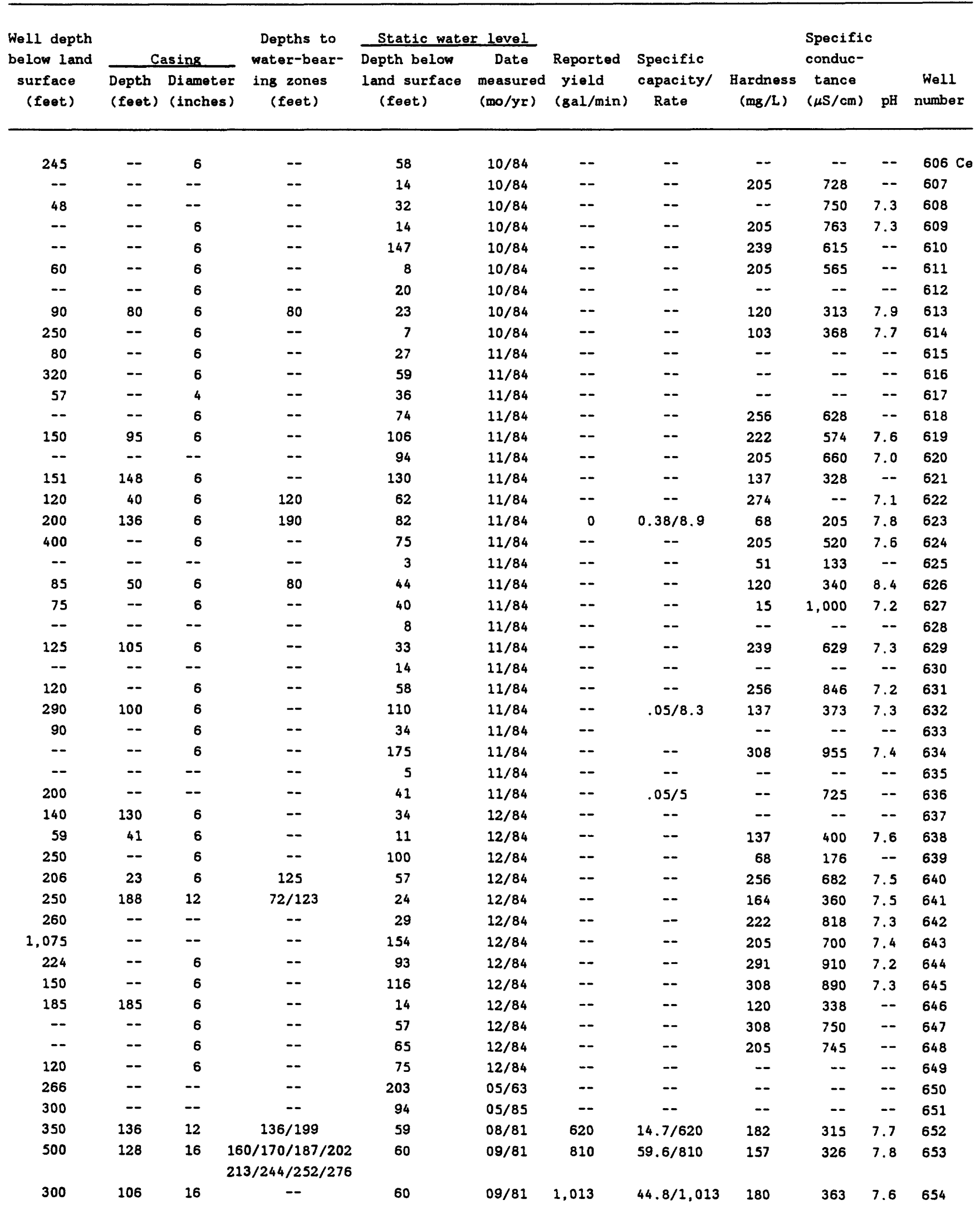




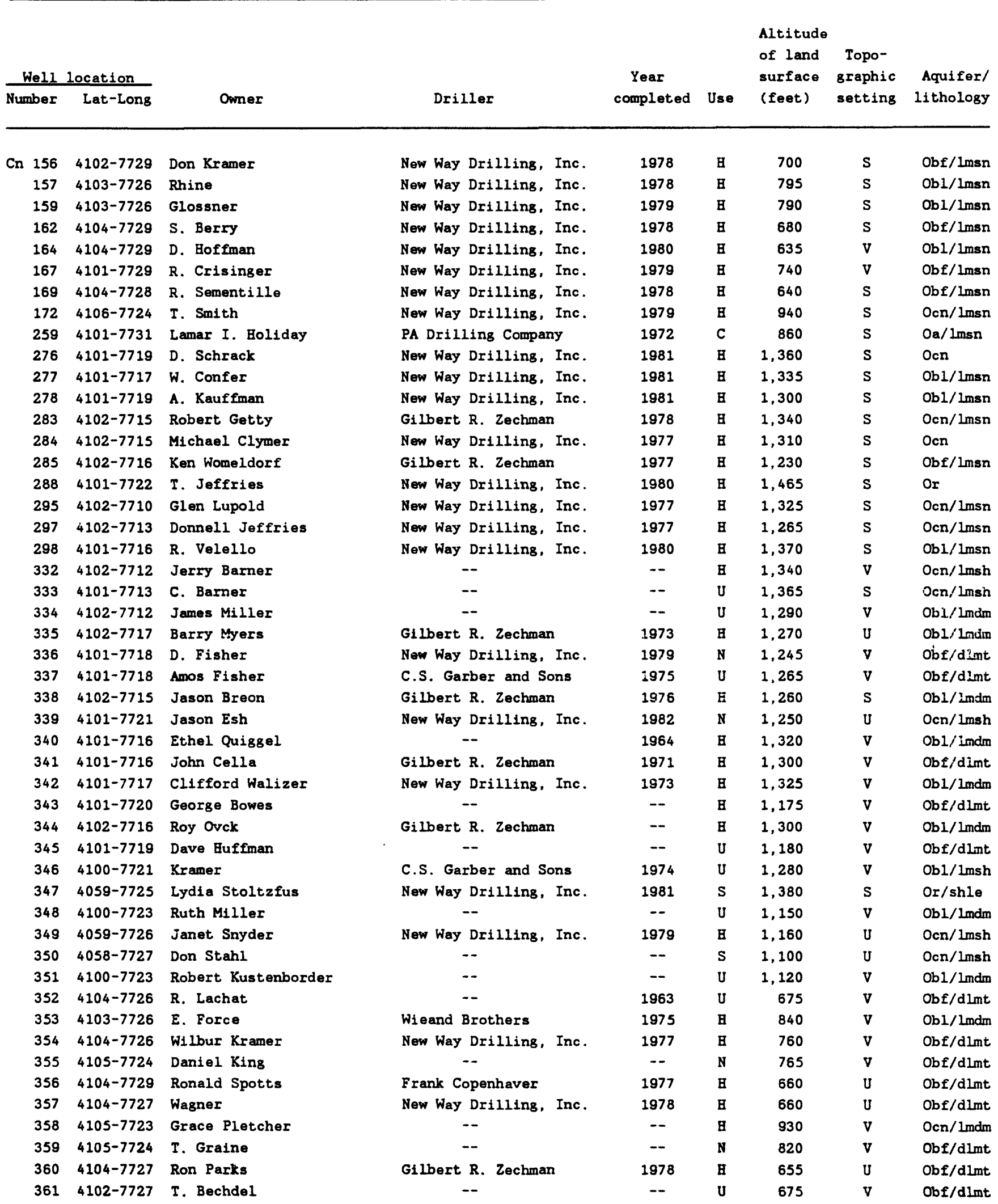




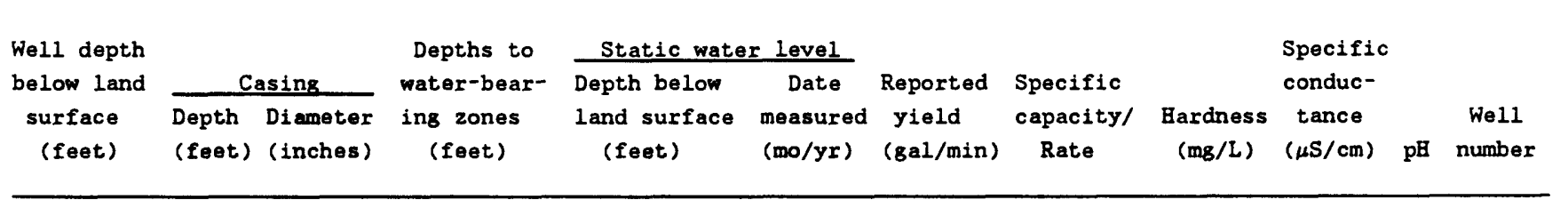

\begin{tabular}{|c|c|c|c|c|c|c|c|c|c|c|c|}
\hline 200 & 30 & 6 & $86 / 186$ & 78 & $07 / 78$ & 4 & $0.03 / 4$ & 188 & 325 & 8.0 & $156 \mathrm{Cn}$ \\
\hline 160 & 65 & 6 & 140 & 70 & $07 / 78$ & 30 & $.33 / 30$ & 154 & 270 & -- & 157 \\
\hline 290 & 70 & 6 & $160 / 284$ & 140 & $06 / 79$ & 60 & $.40 / 60$ & 154 & 280 & -- & 159 \\
\hline 140 & 66 & 6 & 100 & 70 & $01 / 78$ & 7 & $.10 / 7$ & 408 & 600 & -- & 162 \\
\hline 60 & 33 & 6 & $36 / 48$ & 20 & $08 / 80$ & 60 & $1.5 / 60$ & -- & -- & -- & 164 \\
\hline 100 & 77 & 6 & $80 / 96$ & 40 & $10 / 79$ & 60 & $1.00 / 60$ & 307 & 600 & 7.2 & 167 \\
\hline 140 & 21 & 6 & $80 / 120$ & 60 & $04 / 78$ & 15 & $.18 / 15$ & 290 & 520 & 8.2 & 169 \\
\hline 400 & 21 & 6 & $35 / 194$ & 30 & $07 / 79$ & -- & $.01 / 1--$ & 357 & 520 & 8.0 & 172 \\
\hline 250 & 103 & 6 & $79 / 126 / 157 / 204$ & 65 & $09 / 72$ & -- & $6.9 / 83$ & 298 & 106 & 7.6 & 259 \\
\hline 240 & 24 & 6 & $50 / 81 / 153$ & 19 & $06 / 81$ & 12 & $.06 / 12$ & -- & -- & -- & 276 \\
\hline 160 & 120 & 6 & 152 & 41 & $06 / 81$ & 8 & $.09 / 8$ & 188 & 260 & 8.0 & 277 \\
\hline 130 & 100 & 6 & 115 & 40 & $01 / 81$ & 45 & $.50 / 45$ & -- & -- & -- & 278 \\
\hline 201 & 82 & 6 & $95 / 180$ & 77 & $06 / 81$ & 10 & -- & 171 & 260 & 7.7 & 283 \\
\hline 260 & 22 & 6 & 120 & 87 & $06 / 77$ & 4 & $.02 / 4$ & 291 & 500 & 7.3 & 284 \\
\hline 201 & 120 & 6 & $174 / 197$ & 58 & $06 / 81$ & 10 & -- & 291 & 580 & 7.5 & 285 \\
\hline 60 & 23 & 6 & 40 & 2 & $06 / 81$ & 15 & $.50 / 15$ & 103 & 220 & 7.5 & 288 \\
\hline 40 & 4 & 6 & 40 & 10 & $06 / 77$ & 60 & $2.0 / 60$ & -- & -- & -- & 295 \\
\hline 320 & 105 & 6 & $220 / 305$ & 130 & $02 / 77$ & 30 & $.16 / 30$ & 188 & 310 & 7.6 & 297 \\
\hline 100 & 41 & 6 & -- & 70 & $05 / 80$ & 60 & $2.0 / 60$ & 137 & 260 & -- & 298 \\
\hline-- & -- & -- & - & 7 & $07 / 84$ & -- & -- & 154 & 285 & -- & 332 \\
\hline 32 & -- & -- & -- & 3 & $07 / 84$ & -- & -- & 34 & 70 & -- & 333 \\
\hline-- & -- & -- & -- & 63 & $07 / 84$ & -- & -- & -- & -- & -- & 334 \\
\hline 231 & 39 & 6 & $115 / 140 / 212 / 221$ & 56 & $07 / 84$ & 50 & -- & 205 & 380 & 7.3 & 335 \\
\hline 120 & 42 & 6 & $94 / 107$ & 51 & $07 / 84$ & -- & $.46 / 30$ & 205 & 375 & 7.0 & 336 \\
\hline 135 & 127 & 6 & $80 / 130$ & 17 & $07 / 84$ & 30 & $.50 / 30$ & -- & -- & -- & 337 \\
\hline 176 & 124 & 6 & -- & 52 & $07 / 84$ & 30 & -- & 205 & 370 & -- & 338 \\
\hline 275 & 174 & 6 & $189 / 260$ & 43 & $07 / 84$ & 12 & $.01 / 12$ & 171 & 340 & 7.2 & 339 \\
\hline 150 & 130 & 6 & -- & -- & -- & 10 & -- & 137 & 239 & -- & 340 \\
\hline 207 & 176 & 6 & $130 / 180 / 195$ & 84 & $07 / 84$ & 30 & -- & 205 & 295 & 7.4 & 341 \\
\hline 160 & 30 & 6 & -- & 42 & $07 / 84$ & 8 & -- & 68 & 115 & 7.3 & 342 \\
\hline-- & -- & -- & -- & 10 & $07 / 84$ & -- & -- & 120 & 255 & 7.3 & 343 \\
\hline 222 & 56 & 6 & 200 & 65 & $07 / 84$ & 42 & -- & 205 & 760 & -- & 344 \\
\hline 18 & -- & -- & -- & 9 & $07 / 84$ & -- & -- & -- & -- & -- & 345 \\
\hline 320 & 142 & 6 & 315 & 152 & $07 / 84$ & 60 & $.36 / 60$ & -- & -- & -- & 346 \\
\hline 60 & 33 & 6 & 54 & 24 & $07 / 84$ & 60 & $2.0 / 60$ & -- & -- & -- & 347 \\
\hline 9 & -- & -- & -- & 8 & $07 / 84$ & -- & -- & -- & -- & -- & 348 \\
\hline 80 & 47 & 6 & 60 & 5 & $07 / 84$ & 15 & $.20 / 15$ & 137 & 235 & 7.3 & 349 \\
\hline-- & -- & -- & -- & 59 & $07 / 84$ & -- & -- & -- & 108 & 8.0 & 350 \\
\hline-- & -- & -- & -- & 12 & $07 / 84$ & -- & -- & 68 & 140 & 7.5 & 351 \\
\hline 152 & 13 & 6 & -- & 12 & $07 / 84$ & -- & -- & -- & -- & -- & 352 \\
\hline 223 & 166 & 6 & 205 & 153 & $07 / 84$ & 30 & -- & 103 & 202 & 7.4 & 353 \\
\hline 400 & 65 & 6 & 398 & 100 & $07 / 84$ & 30 & $.10 / 30$ & 274 & 575 & 7.8 & 354 \\
\hline-- & -- & -- & -- & 99 & $07 / 84$ & -- & -- & 274 & 740 & -- & 355 \\
\hline 78 & 13 & 6 & $42 / 76$ & 38 & $07 / 84$ & 4 & $.09 / 4$ & 205 & 370 & -- & 356 \\
\hline 220 & 22 & 6 & $116 / 204$ & 64 & $07 / 84$ & 3 & $.03 / 3$ & 239 & 470 & -- & 357 \\
\hline-- & -- & -- & -- & 22 & $07 / 84$ & -- & -- & 110 & 270 & -- & 358 \\
\hline-- & -- & 6 & -- & 107 & $07 / 84$ & -- & -- & 239 & 660 & -- & 359 \\
\hline 90 & 20 & 6 & -- & 28 & $07 / 84$ & -- & -- & 188 & 300 & -- & 360 \\
\hline-- & -- & -- & -- & 20 & $07 / 84$ & -- & -- & -- & -- & -- & 361 \\
\hline
\end{tabular}




\begin{tabular}{|c|c|c|c|c|c|c|c|c|}
\hline \multicolumn{2}{|c|}{ Wel1 location } & Owner & Driller & $\begin{array}{c}\text { Year } \\
\text { completed }\end{array}$ & Use & $\begin{array}{l}\text { Altitude } \\
\text { of land } \\
\text { surface } \\
\text { (feet) }\end{array}$ & $\begin{array}{c}\text { Topo- } \\
\text { graphic } \\
\text { setting }\end{array}$ & $\begin{array}{l}\text { Aquifer/ } \\
\text { lithology }\end{array}$ \\
\hline $\mathrm{Cn} 362$ & $4102-7728$ & Park Barner & -- & -- & H & 700 & U & Obf/dlmt \\
\hline 363 & $4104-7726$ & Ronald Martin & -- & 1976 & $\mathbf{N}$ & 805 & $\mathrm{v}$ & Obf/dlmt \\
\hline 365 & $4102-7729$ & C. Brownlee & -- & -- & $N$ & 730 & $\mathrm{v}$ & Obf/dlmt \\
\hline 366 & $4103-7729$ & Dunkle and Grieb, Inc. & -- & -- & $\mathbf{U}$ & 840 & $\mathbf{U}$ & Obf/dlmt \\
\hline 367 & $4101-7732$ & Dotter Farm & New Way Drilling, Inc. & 1979 & H & 940 & $\mathrm{v}$ & Os/lmsn \\
\hline 368 & $4104-7728$ & Thomas Mann & -- & -- & $\mathbf{N}$ & 720 & $\mathbf{S}$ & Obf/dlmt \\
\hline 369 & $4104-7725$ & John Stevens & -- & -- & $\mathbf{U}$ & 740 & $\mathrm{v}$ & Obf/dlmt \\
\hline 370 & $4101-7731$ & Lamar City Manor & Gilbert R. Zechman & 1984 & C & 870 & $\mathrm{v}$ & Oa/lmsn \\
\hline 375 & $4103-7731$ & Fred Yearick & -- & 1956 & H & 740 & $s$ & Obf/dlmt \\
\hline 376 & $4102-7732$ & Donald Yarrison & Oscar Dearmit & 1963 & H & 920 & $\mathbf{U}$ & $\mathrm{Oa} / \mathrm{lmsn}$ \\
\hline 377 & $4102-7731$ & Harold Bierly & -- & -- & $\mathbf{H}$ & 780 & $\mathrm{~s}$ & Obf/dlmt \\
\hline 378 & $4102-7732$ & Ben Stoltzfus & -- & -- & H & 800 & $\mathbf{s}$ & Obf/dlmt \\
\hline 379 & $4101-7733$ & James Muthler & -- & 1978 & $N$ & 860 & U & $\mathrm{Obf} / \mathrm{dlm} t$ \\
\hline 380 & $4100-7731$ & Alan Bailey & -- & -- & B & 770 & $\mathrm{v}$ & $\mathrm{Obf} / \mathrm{dlm} t$ \\
\hline 381 & $4100-7732$ & George Ruckel & -- & -- & U & 850 & $\mathrm{~V}$ & Oa/lmsn \\
\hline Fu 142 & $3954-7801$ & G. Gress & Larry G. Walters & 1981 & H & 880 & H & Obf/Imsn \\
\hline 143 & $3952-7800$ & G. Bivens & Larry G. Walters & 1982 & E & 800 & $\mathrm{v}$ & Csg/Imsn \\
\hline 144 & $3953-7801$ & D. Seiders & Martin W. Shatzer & 1982 & B & 810 & $\mathrm{v}$ & Orr/lndm \\
\hline 145 & $3953-7801$ & D. Seiders & Martin W. Shatzer & 1979 & $\mathbf{B}$ & 820 & $\mathbf{v}$ & Obf/Lmdm \\
\hline 191 & $3953-7759$ & Great Cove Golf Club & -- & 1978 & c & 880 & $\mathbf{v}$ & Onl/dimt \\
\hline 192 & $3953-7759$ & Great Cove Golf Club & Martin W. Shatzer & 1966 & I & 880 & $\mathrm{v}$ & onl/dlot \\
\hline 193 & $3954-7759$ & J. Sipes & Martin W. Shatzer & 1983 & $\mathbf{H}$ & 990 & $\mathrm{v}$ & Orr/lmdm \\
\hline 194 & $3955-7800$ & Harry Reeder & -- & 1976 & 吾 & 850 & $\mathrm{v}$ & Onl/dimt \\
\hline 195 & $3954-7800$ & Janice Wolfe & Larry G. Walters & 1980 & H & 880 & $\mathbf{s}$ & Onl/dlmt \\
\hline 196 & $3956-7800$ & B. Branch & Martin พ. Shatzer & 1978 & $\mathbf{B}$ & 980 & $\mathbf{s}$ & Oc1/1msn \\
\hline 197 & $3957-7758$ & W.F. Lane & -- & 1950 & $\mathbf{H}$ & 990 & $\mathrm{v}$ & $O b f / 1 m d m$ \\
\hline 198 & $3957-7758$ & W. Lane & -- & -- & U & 990 & $\mathrm{v}$ & Obf \\
\hline 199 & $3957-7758$ & P. Mellott & Martin w. Shatzer & 1981 & 音 & 1,010 & $\mathrm{v}$ & $\mathrm{Obf} / \mathrm{lmdm}$ \\
\hline 200 & $4000-7757$ & R. Johnston & -- & 1979 & $\mathbf{H}$ & 980 & $\mathrm{v}$ & Onl/dlmt \\
\hline 201 & $3957-7758$ & PennDot & -- & 1967 & $\mathbf{N}$ & 1,020 & $\mathrm{v}$ & $\mathrm{Obf} / \mathrm{lmdm}$ \\
\hline 202 & $3958-7758$ & Randall Seiders & -- & 1977 & $\mathbf{B}$ & 1,040 & $\mathrm{v}$ & $O b f / l m d m$ \\
\hline 203 & $3958-7758$ & J. Everts & Larry G. Walters & 1980 & 旦 & 1,130 & $\mathbf{s}$ & $0 \mathrm{cl} / 1 \mathrm{mdm}$ \\
\hline 204 & $3959-7758$ & Helen Garlock & -- & 1968 & $\mathbf{B}$ & 1,010 & $\mathrm{v}$ & $O b f / 1 m d m$ \\
\hline 205 & $3959-7758$ & Paul Hock & Martin W. Shatzer & 1977 & $\mathrm{~s}$ & 1,010 & $\mathrm{v}$ & $O b f / 1 m d m$ \\
\hline 206 & $3959-7757$ & M. Gress & Larry G. Walters & 1982 & $\mathbf{8}$ & 1,160 & $\mathbf{s}$ & Ocl/1msn \\
\hline 207 & $3959-7757$ & J. Armstrong & Martin W. Shatzer & 1981 & $\mathbf{H}$ & 1,160 & $\mathbf{s}$ & Ocl/lmsn \\
\hline 208 & $3959-7758$ & Helen Bender & Larry G. Walters & 1984 & $\mathbf{B}$ & 1,010 & $\mathrm{v}$ & $\mathrm{Obf} / 1 \mathrm{mdm}$ \\
\hline
\end{tabular}




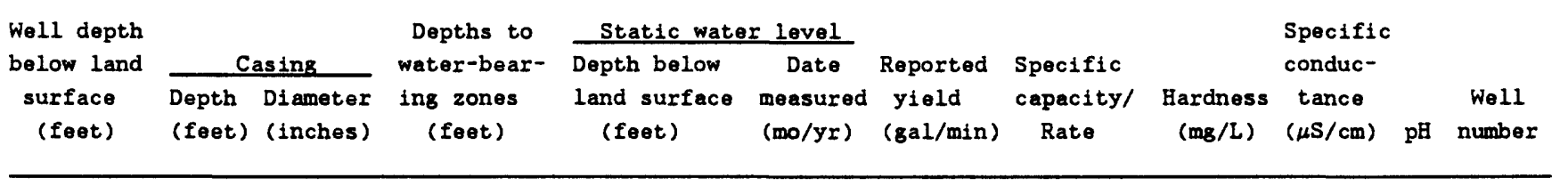

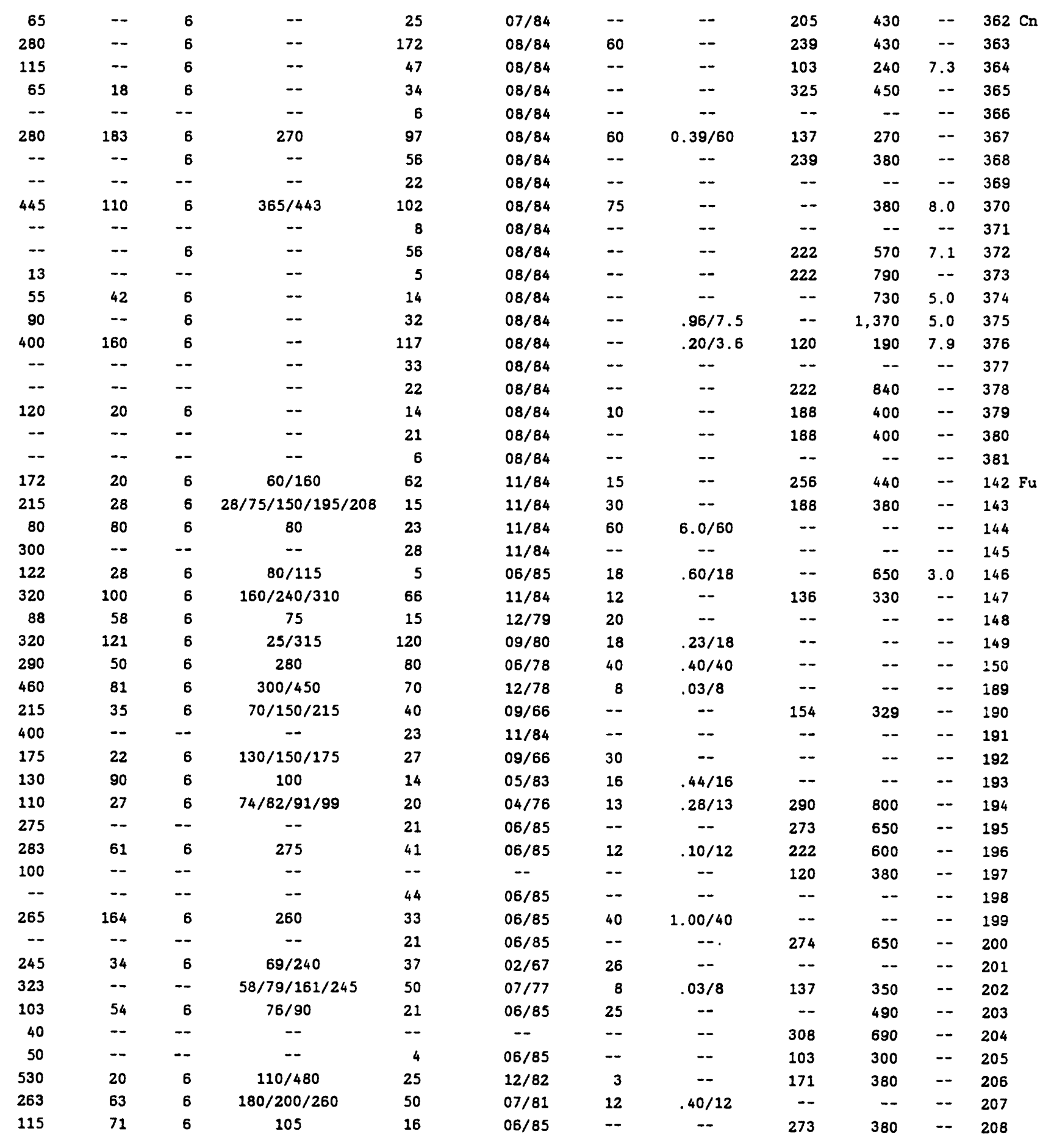




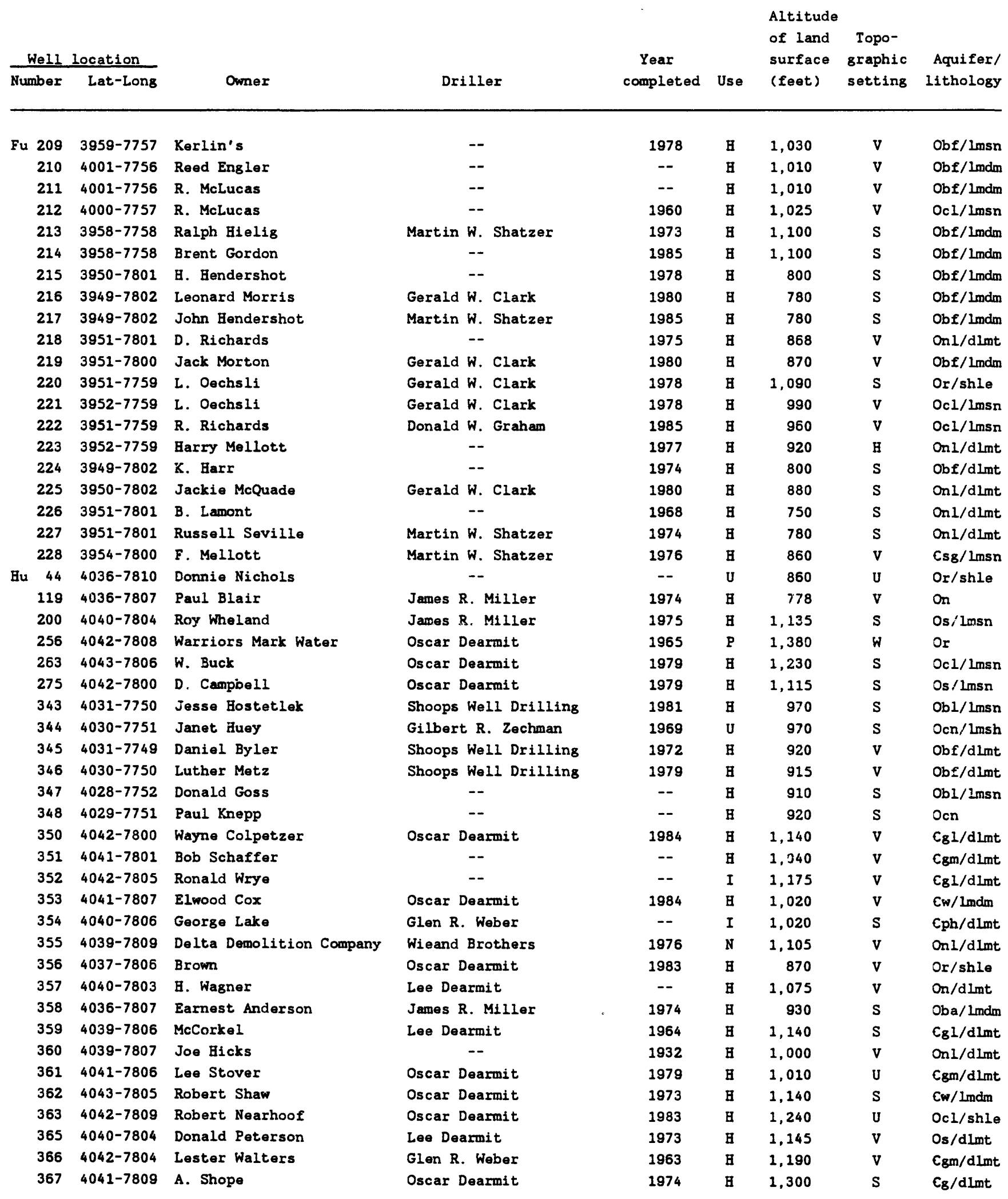


Well depth

surface

(feet)

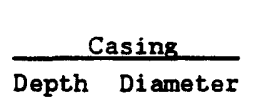

(feet) (inches)
Depths to Static water level

water-bear- Depth below Date Reported Specific

ing zones land surface measured yield

capacity

(mo/yr) ( $\mathrm{gal} / \mathrm{min}$ ) Rate
Specific

conduc-

Hardness tance Well

$(m g / L)(\mu \mathrm{S} / \mathrm{cm})$ pH number

\begin{tabular}{|c|c|c|c|c|c|c|c|c|c|c|c|}
\hline 208 & -- & -- & -- & 36 & $06 / 85$ & -- & -- & 120 & 245 & -- & 209 \\
\hline-- & -- & -- & -- & 34 & $06 / 85$ & -- & -- & 120 & 300 & -- & 210 \\
\hline-- & -- & -- & -- & -- & -- & -- & -- & 137 & 350 & -- & 211 \\
\hline 180 & -- & -- & -- & 16 & $06 / 85$ & -- & -- & -- & 500 & -- & 212 \\
\hline 262 & 82 & 6 & $180 / 262$ & 55 & $06 / 85$ & 20 & -- & 120 & 280 & -- & 213 \\
\hline 106 & 58 & 6 & $62 / 91$ & 38 & $07 / 85$ & 12 & -- & 120 & 340 & -- & 214 \\
\hline 120 & -- & -- & -- & 56 & $07 / 85$ & -- & -- & 290 & 810 & -- & 215 \\
\hline-- & -- & -- & -- & 22 & $07 / 85$ & -- & -- & 274 & 490 & -- & 216 \\
\hline -- & -- & -- & -- & 30 & $07 / 85$ & -- & -- & 274 & 460 & -- & 217 \\
\hline 125 & -- & -- & -- & 95 & $07 / 85$ & -- & -- & 308 & 725 & -- & 218 \\
\hline 300 & -- & -- & -- & 75 & $07 / 85$ & -- & -- & 205 & 460 & -- & 219 \\
\hline 43 & 21 & 6 & $22 / 27$ & 20 & $07 / 85$ & 50 & $1.7 / 50$ & -- & 310 & -- & 220 \\
\hline 264 & 75 & 6 & $48 / 80 / 140 / 248 / 252$ & -- & -- & 8 & -- & -- & 480 & -- & 221 \\
\hline 143 & -- & -- & -- & 34 & $07 / 85$ & 15 & -- & 137 & 350 & -- & 222 \\
\hline 196 & 29 & 6 & $47 / 163 / 186$ & 29 & $07 / 85$ & 8 & $0.09 / 8$ & 308 & 800 & -- & 223 \\
\hline 250 & -- & -- & -- & 72 & $07 / 85$ & -- & -- & 188 & 410 & -- & 224 \\
\hline-- & -- & -- & -- & 100 & $07 / 85$ & -- & -- & 170 & 430 & -- & 225 \\
\hline 50 & -- & -- & -- & -- & -- & -- & -- & -- & 540 & -- & 226 \\
\hline-- & -- & -- & -- & 64 & $07 / 85$ & -- & -- & 256 & 610 & -- & 227 \\
\hline 285 & 40 & 6 & $180 / 275$ & 100 & $05 / 76$ & 50 & $2.0 / 50$ & -- & -- & -- & 228 \\
\hline 23 & -- & -- & -- & 14 & $08 / 84$ & -- & -- & -- & -- & -- & 44 \\
\hline 45 & 20 & 6 & $25 / 30$ & 8 & $06 / 80$ & 40 & -- & 171 & -- & -- & 119 \\
\hline 145 & 90 & 6 & $100 / 120$ & -- & -- & 18 & -- & 171 & 320 & -- & 200 \\
\hline 435 & 23 & 6 & $45 / 240$ & 1 & $07 / 65$ & 20 & $.21 / 20$ & -- & -- & -- & 256 \\
\hline 210 & 20 & 6 & 200 & 9 & $07 / 80$ & 3 & -- & 154 & 420 & 8.9 & 263 \\
\hline 125 & 52 & 6 & 115 & 32 & $07 / 80$ & 100 & $3.9 / 8.0$ & 137 & 350 & -- & 275 \\
\hline 270 & 20 & 6 & $100 / 265$ & 14 & $04 / 84$ & 15 & -- & 222 & 500 & -- & 343 \\
\hline 197 & 124 & 6 & $160 / 185$ & 30 & $04 / 84$ & -- & -- & -- & -- & -- & 344 \\
\hline 180 & -- & -- & - & 15 & $04 / 84$ & -- & -- & 239 & 490 & 7.3 & 345 \\
\hline 175 & 60 & 6 & -- & 4 & $04 / 84$ & -- & -- & 222 & 455 & -- & 346 \\
\hline 26 & -- & -- & -- & 4 & $04 / 84$ & -- & -- & 154 & 340 & -- & 347 \\
\hline-- & -- & -- & -- & 20 & $04 / 84$ & -- & -- & 85 & 160 & -- & 348 \\
\hline 195 & 56 & 6 & 195 & 61 & $06 / 84$ & 9 & $.14 / 7.1$ & 171 & 660 & 6.9 & 350 \\
\hline 20 & -- & -- & -- & 7 & $06 / 84$ & -- & -- & -- & -- & -- & 351 \\
\hline 15 & -- & -- & -- & 5 & $06 / 84$ & -- & -- & 86 & 370 & -- & 352 \\
\hline 60 & 57 & 6 & -- & -- & -- & -- & -- & 154 & 555 & 7.2 & 353 \\
\hline 75 & 30 & 6 & -- & 44 & $06 / 84$ & -- & -- & 137 & 580 & -- & 354 \\
\hline 223 & 102 & 6 & -- & 109 & $06 / 84$ & -- & -- & 120 & 415 & 7.7 & 355 \\
\hline 137 & 40 & 6 & 127 & 16 & $06 / 84$ & 3 & -- & 205 & 642 & -- & 356 \\
\hline 175 & -- & -- & -- & 20 & $06 / 84$ & -- & $160 / 8.0$ & 171 & 910 & -- & 357 \\
\hline 185 & 67 & 6 & 142 & 94 & $06 / 84$ & -- & -- & 137 & 560 & 7.6 & 358 \\
\hline 296 & -- & -- & -- & -- & -- & -- & -- & 120 & 538 & 7.5 & 359 \\
\hline 125 & -- & -- & -- & 53 & $06 / 84$ & -- & -- & 154 & 733 & -- & 360 \\
\hline 95 & -- & -- & -- & 30 & $06 / 84$ & -- & -- & 34 & 66 & 7.8 & 361 \\
\hline 180 & 43 & 6 & 80 & 67 & $06 / 84$ & 2 & -- & 171 & 555 & 7.4 & 362 \\
\hline 130 & 36 & 6 & 120 & -- & $06 / 84$ & 7 & -- & 51 & 268 & 7.6 & 363 \\
\hline 140 & -- & -- & -- & 90 & $06 / 84$ & 1 & -- & -- & -- & -- & 365 \\
\hline 173 & -- & -- & -- & 117 & $06 / 84$ & -- & -- & 154 & 910 & 7.9 & 366 \\
\hline 300 & 241 & 6 & 300 & 257 & $07 / 84$ & 15 & -- & 120 & 360 & -- & 367 \\
\hline
\end{tabular}


Table 1.--Record of wells--Continued

\begin{tabular}{|c|c|c|c|c|c|c|c|c|}
\hline \multicolumn{2}{|c|}{ Well location } & Owner & Driller & $\begin{array}{c}\text { Year } \\
\text { completed }\end{array}$ & Use & $\begin{array}{l}\text { Altitude } \\
\text { of land } \\
\text { surface } \\
\text { (feet) }\end{array}$ & $\begin{array}{c}\text { Topo- } \\
\text { graphic } \\
\text { setting }\end{array}$ & $\begin{array}{l}\text { Aquifer } \\
\text { lithology }\end{array}$ \\
\hline Bu 368 & $4041-7812$ & Elmo Richards & Oscar Dearmit & 1974 & 日 & 1,110 & $\mathbf{s}$ & Onl/1mdm \\
\hline 369 & $4041-7811$ & David Clark & Oscar Dearmit & 1983 & В & 1,080 & $\mathrm{U}$ & $0 c 1 / 1 \mathrm{mdm}$ \\
\hline 371 & $4038-7806$ & L. Myers & Oscar Dearmit & 1968 & В & 880 & $U$ & Obf/dlmt \\
\hline 372 & $4037-7810$ & Interstate Amiesite & James R. Miller & 1984 & C & 800 & $\mathrm{v}$ & $0 c 1 / 1 m d m$ \\
\hline 373 & $4034-7808$ & Lovey Shaffer & James R. Miller & 1973 & В & 840 & $\mathrm{v}$ & On1 \\
\hline 374 & $4033-7810$ & Charles Weko & Donald W. Graham & 1983 & B & 1,010 & $\mathrm{U}$ & $\mathrm{Oba} / \mathrm{lmdm}$ \\
\hline 375 & $4032-7811$ & William Riley & James R. Miller & 1975 & I & 1,060 & $\mathbf{s}$ & $0 \mathrm{c} 1 / 1 \mathrm{mdm}$ \\
\hline 376 & $4035-7808$ & James Harpster & James R. Miller & 1976 & H & 1,020 & $\mathrm{U}$ & $\mathrm{Oba} / 1 \mathrm{mdm}$ \\
\hline 381 & $4042-7807$ & John Peters & -- & -- & H & 1,095 & $\mathrm{v}$ & $\mathrm{Cw}_{\mathrm{w}} \mathrm{dl} \mathrm{lmt}$ \\
\hline 382 & $4043-7806$ & Sarmuel Conrad & -- & -- & 0 & 1,200 & $s$ & $\mathrm{Oba} / \mathrm{lmdm}$ \\
\hline 383 & $4042-7806$ & Guy Miller & -- & -- & $U$ & 1,200 & $U$ & $\epsilon_{g 1 / d l m t}$ \\
\hline 384 & $4044-7806$ & Frilling & -- & -- & $\mathbf{N}$ & 1,240 & $\mathrm{v}$ & Ocl/1msh \\
\hline 385 & $4039-7804$ & Glenn Bouck & Oscar Dearmit & 1954 & $U$ & 1,040 & $\mathrm{v}$ & $\mathrm{Obf} / \mathrm{dlmt}$ \\
\hline 386 & $4036-7809$ & Wallace Estate & -- & -- & $U$ & 1,025 & H & $\mathrm{Oba} / 1 \mathrm{mdm}$ \\
\hline 387 & $4037-7809$ & Harry Gensimore & -- & -- & I & 1,040 & $U$ & $\mathrm{Oba} / \mathrm{imdm}$ \\
\hline 389 & $4036-7808$ & Joseph Kurtz & -- & -- & H & 790 & $\mathbf{s}$ & onl/lmsn \\
\hline 390 & $4032-7809$ & Jack Edmuncis & -- & 1976 & H & 800 & $\mathrm{v}$ & $\mathrm{Oba} / \mathrm{mdm}$ \\
\hline 391 & $4033-7808$ & Walter Ball & -- & -- & $U$ & 920 & $\mathbf{F}$ & Or/shle \\
\hline 392 & $4033-7809$ & Beckey Donnelly & -- & -- & $\mathbb{N}$ & 870 & v & Onl/1msn \\
\hline 400 & $4039-7810$ & W. Grebe & -- & -- & H & 1,160 & $\mathrm{v}$ & $\mathrm{cg}_{\mathrm{g} / \mathrm{dlm} t}$ \\
\hline 401 & $4038-7809$ & John Strover & Herman E. Bousum & 1976 & $U$ & 1,065 & $\mathrm{v}$ & $\mathrm{Oba} / \mathrm{lmdm}$ \\
\hline 402 & $4038-7808$ & Edward Newlin & -- & -- & $\mathbf{s}$ & 985 & $\mathrm{v}$ & On1/1msn \\
\hline 403 & $4037-7809$ & Mike Rugh & -- & -- & H & 1,055 & $\mathbf{v}$ & $\mathrm{Oba} / \mathrm{lmdm}$ \\
\hline 404 & $4038-7809$ & William Boover & -- & -- & $\mathrm{U}$ & 1,045 & $\mathbf{v}$ & Onl/1msn \\
\hline 405 & $4040-7811$ & Lois Peck & -- & 1959 & $\mathbf{s}$ & 1,065 & $\mathbf{s}$ & $\mathrm{Oba} / 1 \mathrm{mdm}$ \\
\hline 406 & $4039-7809$ & M. Givler & -- & -- & 甘 & 1,200 & U & $\epsilon_{8} / \mathrm{dlmt}$ \\
\hline 407 & $4041-7811$ & Steve Burns & Martin W. Shatzer & 1984 & B & 1,080 & $U$ & Oc1/Imsn \\
\hline 408 & $4033-7809$ & Walter HaLl & -- & -- & $\mathrm{U}$ & 1,030 & H & $\mathrm{Oba} / \mathrm{lmdm}$ \\
\hline 409 & $4034-7809$ & Earl Sunderland & -- & -- & $U$ & 930 & $\mathbf{v}$ & Onl/Imdm \\
\hline 410 & $4043-7806$ & Frilling & -- & 1968 & U & 1,230 & $\mathrm{v}$ & Oba \\
\hline 411 & $4012-7754$ & พ. McElrath & Larry Walters & 1981 & H & 775 & $\mathrm{v}$ & Ocn/1msn \\
\hline 412 & $4011-7752$ & Kennith Whitsel & -- & -- & $\mathbf{B}$ & 885 & $s$ & Ocn/lmsn \\
\hline 413 & $4010-7753$ & Walter Murphy & -- & -- & B & 905 & $\mathbf{s}$ & Ocn/1msn \\
\hline 414 & $4010-7753$ & P. Voll & Martin W. Shatzer & 1980 & 且 & 895 & $\mathrm{v}$ & Ocn/lmsn \\
\hline 415 & $4014-7751$ & Fred Laird & -- & -- & 日 & 718 & $\mathrm{v}$ & Ocn/1msn \\
\hline 416 & $4014-7751$ & John Plank & -- & -- & $\mathbf{8}$ & 742 & $\mathbf{s}$ & Ocn/Imsn \\
\hline 417 & $4014-7751$ & Leon Riegel & -- & -- & B & 782 & $\mathbf{s}$ & Ocn/1msn \\
\hline
\end{tabular}


Well depth
below land $\begin{gathered}\text { Depths to } \\ \text { Casing Static water level }\end{gathered}$

surface Depth Dianeter ing zones land surface measured yield capacity/ Hardness tance (feet) (feet) (inches) (feet) (feet) (mo/yr) (gal/min) Rate (mg/L) ( $\mu$ S/cm) pH number

\begin{tabular}{|c|c|c|c|c|c|c|c|c|c|c|c|}
\hline 143 & 71 & 6 & $83 / 103 / 130$ & 80 & $07 / 84$ & 20 & -- & 222 & 475 & 7.4 & $368 \mathrm{Hu}$ \\
\hline 400 & 161 & 6 & 390 & 163 & $07 / 84$ & 100 & -- & 257 & 660 & 7.6 & 369 \\
\hline-- & -- & -- & -- & 47 & $06 / 84$ & -- & -- & 120 & 450 & 7.5 & 370 \\
\hline 42 & 36 & 2 & 42 & 15 & $07 / 84$ & 25 & -- & -- & -- & -- & 371 \\
\hline 65 & 31 & 6 & 58 & 8 & $07 / 84$ & 90 & -- & 257 & 762 & -- & 372 \\
\hline 205 & 21 & 6 & $175 / 180$ & 22 & $07 / 84$ & 17 & -- & 154 & 505 & -- & 373 \\
\hline 410 & -- & -- & -- & 15 & $07 / 84$ & -- & -- & 239 & 467 & -- & 374 \\
\hline 265 & 20 & -- & $80 / 240 / 248$ & 50 & $07 / 84$ & 36 & -- & 222 & 486 & -- & 375 \\
\hline 245 & 85 & 6 & $180 / 220$ & 104 & $07 / 84$ & 2 & -- & 222 & 860 & -- & 376 \\
\hline 305 & 76 & 6 & $145 / 240 / 269$ & 186 & $07 / 84$ & 4 & -- & -- & -- & -- & 377 \\
\hline 125 & 50 & 6 & -- & 31 & $07 / 84$ & 100 & -- & 171 & 315 & 7.3 & 378 \\
\hline-- & -- & -- & -- & 42 & $07 / 84$ & -- & -- & 103 & 160 & 7.6 & 379 \\
\hline-- & -- & -- & -- & 15 & $07 / 84$ & -- & -- & 68 & 140 & 7.2 & 380 \\
\hline-- & -- & -- & -- & 33 & $07 / 84$ & -- & -- & 171 & 328 & -- & 381 \\
\hline 90 & -- & -- & -- & 34 & $07 / 84$ & -- & $3.1 / 6.7$ & -- & 570 & -- & 382 \\
\hline-- & -- & -- & -- & 2 & $07 / 84$ & -- & -- & -- & -- & -- & 383 \\
\hline-- & -- & -- & -- & -- & $07 / 84$ & -- & -- & 137 & 270 & -- & 384 \\
\hline 197 & 30 & 6 & -- & 12 & $07 / 84$ & -- & -- & -- & -- & -- & 385 \\
\hline-- & -- & -- & -- & 32 & $08 / 84$ & -- & -- & -- & -- & -- & 386 \\
\hline 22 & -- & -- & -- & 4 & $08 / 84$ & -- & -- & 222 & 455 & -- & 387 \\
\hline-- & -- & -- & -- & 27 & $08 / 84$ & -- & -- & 239 & 580 & 6.2 & 389 \\
\hline 124 & 124 & 6 & -- & 36 & $08 / 84$ & -- & -- & 222 & 455 & -- & 390 \\
\hline-- & -- & -- & -- & 4 & $08 / 84$ & -- & -- & 51 & 170 & -- & 391 \\
\hline 50 & -- & -- & -- & 25 & $08 / 84$ & -- & -- & 205 & 611 & -- & 392 \\
\hline-- & -- & 6 & -- & 8 & $09 / 84$ & -- & -- & 188 & 566 & -- & 393 \\
\hline 190 & -- & 6 & -- & 109 & $09 / 84$ & 40 & $5.6 / 13.4$ & 171 & 445 & -- & 394 \\
\hline-- & -- & 6 & -- & 82 & $09 / 84$ & -- & -- & 239 & 728 & -- & 395 \\
\hline 260 & -- & 6 & -- & 7 & $09 / 84$ & 3 & -- & 171 & 705 & -- & 396 \\
\hline 400 & -- & 6 & -- & 92 & $09 / 84$ & -- & -- & -- & -- & -- & 397 \\
\hline 57 & -- & 6 & -- & 17 & $09 / 84$ & -- & -- & -- & 450 & 8.1 & 398 \\
\hline 195 & -- & 6 & -- & 166 & $09 / 84$ & -- & -- & 103 & 270 & 8.3 & 399 \\
\hline 137 & -- & 6 & -- & 67 & $09 / 84$ & -- & -- & 103 & 271 & 7.9 & 400 \\
\hline 127 & 127 & 6 & -- & 118 & $09 / 84$ & -- & -- & -- & -- & -- & 401 \\
\hline-- & -- & 6 & -- & 58 & $09 / 84$ & -- & -- & 205 & 511 & 8.0 & 402 \\
\hline 277 & -- & 6 & -- & 68 & $09 / 84$ & -- & -- & 239 & 610 & 8.4 & 403 \\
\hline 25 & -- & -- & -- & 6 & $09 / 84$ & -- & -- & -- & -- & -- & 404 \\
\hline 120 & -- & 6 & -- & 100 & $09 / 84$ & -- & -- & 222 & 595 & 7.9 & 405 \\
\hline-- & -- & -- & -- & 10 & $09 / 84$ & -- & -- & -- & -- & -- & 406 \\
\hline 180 & -- & -- & -- & 159 & $05 / 85$ & -- & -- & -- & -- & -- & 407 \\
\hline 155 & -- & -- & -- & 58 & $05 / 85$ & -- & -- & -- & -- & -- & 408 \\
\hline 67 & -- & -- & . $\quad--$ & 37 & $04 / 85$ & -- & -- & -- & -- & -- & 409 \\
\hline 505 & -- & -- & -- & 6 & $05 / 85$ & -- & $0.07 / 5$ & -- & 750 & -- & 410 \\
\hline 142 & 42 & 6 & $80 / 130$ & 16 & $07 / 86$ & 25 & -- & 137 & 775 & 7.5 & 411 \\
\hline 308 & -- & -- & -- & 41 & $07 / 86$ & -- & -- & 274 & 600 & 7.4 & 412 \\
\hline 105 & -- & -- & -- & 23 & $07 / 86$ & 10 & -- & 42 & 215 & 7.0 & 413 \\
\hline 180 & 40 & 6 & 170 & 32 & $07 / 86$ & 20 & -- & 137 & 400 & 8.0 & 414 \\
\hline 72 & -- & -- & -- & 24 & $07 / 86$ & -- & -- & 171 & 545 & 7.0 & 415 \\
\hline 275 & -- & -- & -- & 54 & $07 / 86$ & -- & -- & 222 & 680 & 7.0 & 416 \\
\hline-- & -- & -- & -- & 31 & $07 / 86$ & -- & -- & 124 & 355 & 6.2 & 417 \\
\hline
\end{tabular}




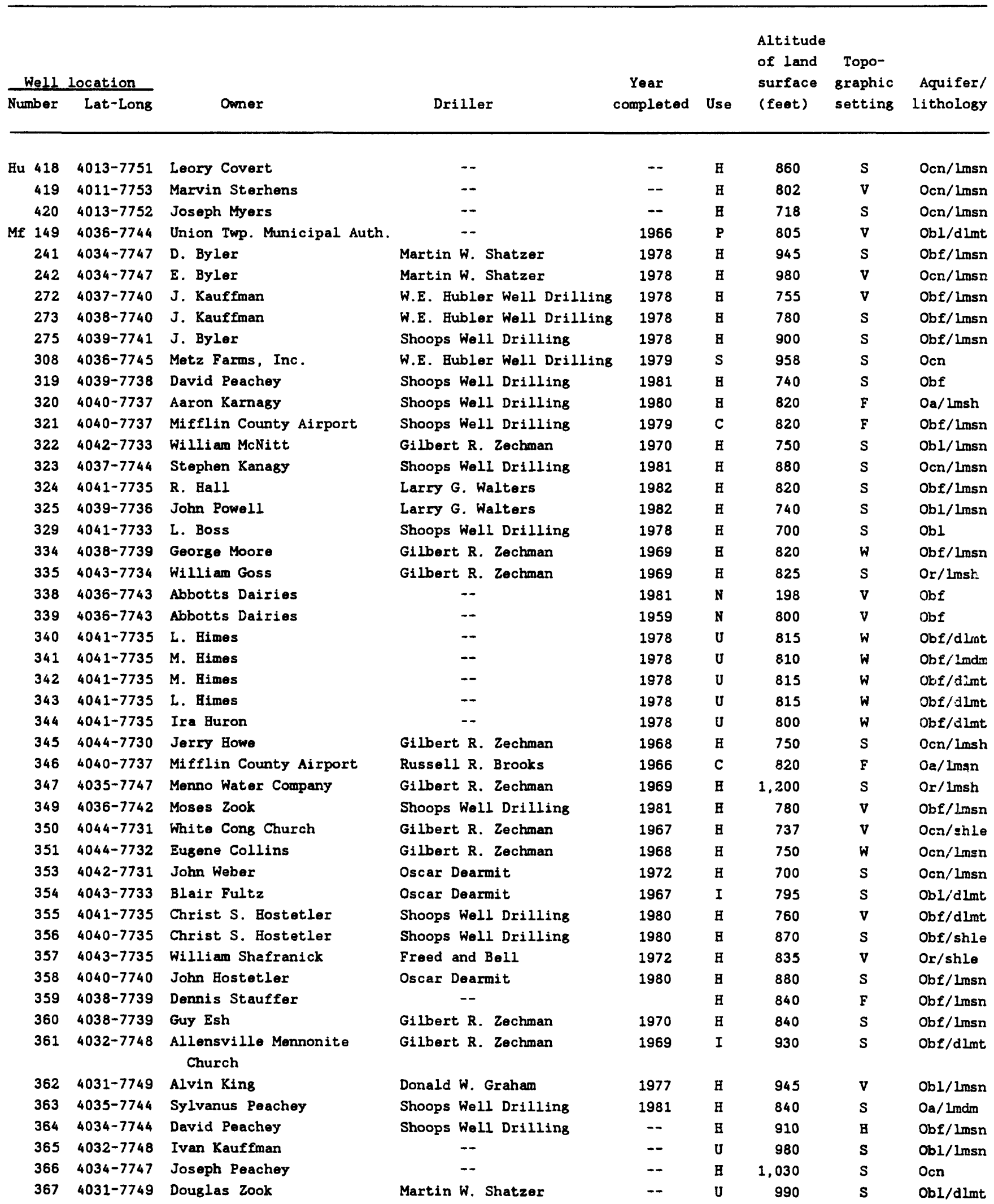




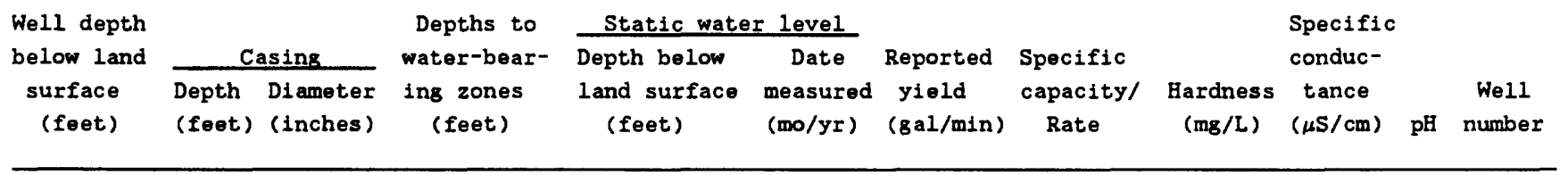

\begin{tabular}{|c|c|c|c|c|c|c|c|c|c|c|c|}
\hline-- & -- & -- & -- & 3 & $07 / 86$ & -- & -- & 188 & 422 & 7.0 & $418 \mathrm{Hu}$ \\
\hline 75 & -- & -- & -- & 8 & $07 / 86$ & -- & -- & 86 & 218 & 8.0 & 419 \\
\hline-- & -- & -- & -- & 20 & $07 / 86$ & -- & -- & 105 & 295 & 7.0 & 420 \\
\hline 201 & 32 & 8 & $35 / 75 / 145 / 187$ & 28 & $05 / 66$ & -- & $30 / 300$ & 295 & -- & 7.4 & $149 \mathrm{Mf}$ \\
\hline 300 & -- & -- & $185 / 280$ & 87 & $07 / 80$ & -- & $0.04 / 8$ & 188 & 480 & 7.2 & 241 \\
\hline 300 & -- & -- & -- & 26 & $07 / 80$ & 5 & $.03 / 5$ & -- & -- & -- & 242 \\
\hline 70 & 48 & 6 & 57 & 24 & $07 / 80$ & 10 & $.50 / 10$ & 323 & 605 & -- & 272 \\
\hline 90 & 33 & 6 & $50 / 80$ & 53 & $07 / 80$ & 10 & $.03 / 2.0$ & 256 & 660 & -- & 273 \\
\hline 275 & 21 & 6 & $160 / 255$ & 45 & $07 / 80$ & 20 & -- & 374 & 810 & -- & 275 \\
\hline 95 & 25 & 6 & $50 / 85$ & 1 & $08 / 80$ & 25 & -- & -- & -- & -- & 308 \\
\hline 200 & 70 & 6 & 195 & 27 & $10 / 83$ & 12 & -- & 376 & 750 & -- & 319 \\
\hline 165 & 91 & 6 & $90 / 160$ & 40 & $12 / 80$ & 25 & -- & 256 & 520 & 6.8 & 320 \\
\hline 150 & 54 & 6 & 135 & 61 & $11 / 83$ & 10 & $5 / 4.0$ & 256 & 480 & -- & 321 \\
\hline 271 & 38 & 6 & $100 / 158 / 260$ & 80 & $02 / 70$ & 7 & -- & -- & -- & -- & 322 \\
\hline 275 & 31 & 6 & 270 & 22 & $06 / 81$ & 10 & -- & -- & -- & -- & 323 \\
\hline 290 & 98 & 6 & $170 / 260 / 280$ & 60 & $11 / 82$ & 12 & -- & -- & -- & -- & 324 \\
\hline 275 & 114 & 6 & $170 / 210 / 260$ & 108 & $10 / 83$ & 7 & -- & 274 & 580 & 6.6 & 325 \\
\hline 100 & 20 & 6 & $80 / 95$ & -- & -- & 15 & -- & 307 & 570 & -- & 329 \\
\hline 222 & 94 & 6 & $135 / 215$ & 50 & $07 / 69$ & 35 & -- & -- & -- & -- & 334 \\
\hline 247 & 39 & 6 & $90 / 238 / 242$ & 3 & $11 / 83$ & 30 & -- & 256 & 495 & -- & 335 \\
\hline 200 & -- & -- & -- & 100 & $01 / 51$ & 350 & -- & -- & -- & -- & 338 \\
\hline 475 & -- & -- & -- & -- & -- & 500 & -- & -- & -- & -- & 339 \\
\hline 200 & 42 & 6 & -- & 94 & $09 / 78$ & 3 & -- & -- & -- & -- & 340 \\
\hline 200 & 42 & 6 & $86 / 163$ & 51 & $04 / 83$ & 3 & -- & -- & -- & -- & 341 \\
\hline 200 & 42 & 6 & $57 / 112 / 150$ & 49 & $04 / 83$ & 25 & -- & -- & -- & -- & 342 \\
\hline 200 & 84 & 6 & 74 & 52 & $04 / 83$ & 6 & -- & -- & -- & -- & 343 \\
\hline 200 & 42 & 6 & $78 / 162 / 172 / 181$ & 41 & $04 / 83$ & 12 & -- & -- & -- & -- & 344 \\
\hline 172 & 91 & 6 & $101 / 116 / 167$ & 40 & $11 / 83$ & 30 & -- & 205 & 260 & 7.2 & 345 \\
\hline 225 & 49 & 6 & $100 / 167 / 220$ & -- & -- & 15 & -- & -- & -- & -- & 346 \\
\hline 346 & 43 & 8 & $88 / 105$ & -- & -- & -- & - & -- & -- & -- & 347 \\
\hline 125 & 96 & 6 & $85 / 120$ & 31 & $11 / 83$ & 30 & $1.2 / 10.9$ & 410 & 875 & -- & 349 \\
\hline 72 & 40 & 6 & $45 / 53 / 66$ & 9 & $11 / 83$ & 8 & -- & -- & -- & -- & 350 \\
\hline 172 & 75 & 6 & $90 / 155 / 162$ & -- & -- & 12 & -- & -- & -- & -- & 351 \\
\hline 126 & 41 & 6 & $95 / 115$ & 27 & $11 / 83$ & 6 & $.15 / 6$ & 239 & 500 & -- & 353 \\
\hline 180 & 20 & 6 & $147 / 170 / 175$ & 100 & $11 / 83$ & 20 & -- & 308 & 675 & -- & 354 \\
\hline 125 & 21 & 6 & 123 & 79 & $11 / 83$ & 10 & -- & 308 & 580 & -- & 355 \\
\hline 210 & 75 & 6 & 207 & -- & -- & 10 & -- & -- & -- & -- & 356 \\
\hline 110 & 33 & 6 & $38 / 68 / 97$ & 36 & $11 / 83$ & 25 & $.28 / 25$ & 205 & 450 & -- & 357 \\
\hline 400 & 56 & 6 & 125 & 54 & $11 / 83$ & 3 & -- & -- & -- & -- & 358 \\
\hline 123 & -- & -- & -- & 89 & $11 / 83$ & -- & -- & -- & -- & -- & 359 \\
\hline 147 & 41 & 6 & $80 / 140$ & -- & -- & -- & -- & -- & -- & -- & 360 \\
\hline 297 & 40 & 6 & $90 / 117 / 136$ & 9 & $04 / 84$ & 3 & -- & 342 & 750 & -- & 361 \\
\hline 200 & -- & -- & -- & 50 & $04 / 84$ & -- & -- & 222 & 500 & -- & 362 \\
\hline 275 & 30 & 6 & $130 / 270$ & 48 & $04 / 84$ & 15 & -- & 360 & 750 & 7.6 & 363 \\
\hline 285 & -- & -- & -- & 46 & $04 / 84$ & -- & -- & -- & -- & -- & 364 \\
\hline 34 & -- & -- & -- & 9 & $04 / 84$ & -- & -- & -- & -- & -- & 365 \\
\hline 30 & -- & -- & -- & 17 & $04 / 84$ & -- & -- & -- & -- & -- & 366 \\
\hline-- & -- & -- & -- & 39 & $04 / 84$ & -- & $.19 / 6$ & 256 & 865 & 6.9 & 367 \\
\hline
\end{tabular}




\begin{tabular}{|c|c|c|c|c|c|c|c|c|}
\hline We11 & location & \multirow[b]{2}{*}{ Owner } & \multirow[b]{2}{*}{ Driller } & \multirow{2}{*}{$\begin{array}{c}\text { Year } \\
\text { completed }\end{array}$} & \multirow[b]{2}{*}{ Use } & \multirow{2}{*}{$\begin{array}{l}\text { Altitude } \\
\text { of land } \\
\text { surface } \\
\text { (feet) }\end{array}$} & \multirow{2}{*}{$\begin{array}{c}\text { Topo- } \\
\text { graphic } \\
\text { setting }\end{array}$} & \multirow{2}{*}{$\begin{array}{l}\text { Aquifer/ } \\
\text { lithology }\end{array}$} \\
\hline Number & Lat-Long & & & & & & & \\
\hline Mf 368 & $4033-7745$ & Alvin Hostetler & -- & -- & U & 930 & $\mathbf{S}$ & Ocn/Imsn \\
\hline 369 & $4040-7738$ & Edward G. Miller & -- & -- & $\mathbf{S}$ & 805 & W & Obf/dlmt \\
\hline 370 & $4039-7739$ & Edward G. Miller & -- & -- & U & 820 & $\mathbf{S}$ & Oa/1mdm \\
\hline 371 & $4038-7740$ & Mahlon Peachey & W.E. Aubler Well Drilling & 1980 & $\mathbf{B}$ & 880 & $\mathbf{S}$ & Oa/lmdm \\
\hline 372 & $4038-7741$ & Aaron Kanagy & Gilbert R. Zechman & 1972 & 田 & 860 & H & Oa/lmdm \\
\hline 373 & $4034-7745$ & Willard Peachey & Shoops Well Drilling & -- & $\mathbf{S}$ & 855 & $\mathbf{S}$ & Oa/Imdm \\
\hline 374 & $4035-7745$ & Kennith Kauffman & Freed and Bell & 1968 & H & 880 & $\mathbf{S}$ & Obf/dlmt \\
\hline 375 & $4035-7742$ & Samuel Peight & Gilbert R. Zechman & 1970 & H & 800 & $\mathbf{v}$ & Obf/dlmt \\
\hline 376 & $4037-7741$ & Joseph Peight & Gilbert R. Zechman & 1972 & H & 830 & $\mathbf{S}$ & Oa/Imdm \\
\hline 377 & $4036-7742$ & Valley View Church & Gilbert R. Zechman & 1972 & I & 860 & $\mathbf{S}$ & Oa/1mdm \\
\hline 378 & $4039-7741$ & Eugene Brubaker & Gilbert R. Zechman & 1972 & S & 840 & $\mathbf{S}$ & Oa/1mdm \\
\hline 379 & $4036-7741$ & J. Glick & -- & 1971 & H & 820 & $\mathbf{S}$ & Oa/lmdm \\
\hline 380 & $4037-7742$ & Paul Smoker & Gilbert R. Zechman & 1984 & S & 845 & $\mathbf{W}$ & Obf/lmsn \\
\hline 381 & $4037-7742$ & Michael Smoker & Shoops Well Drilling & 1977 & 旦 & 850 & $\mathbf{S}$ & Obf/1mdm \\
\hline 383 & $4042-7736$ & M. Hostetler & W.E. Hubler Well Drilling & 1982 & H & 900 & $\mathbf{S}$ & Or/shle \\
\hline 384 & $4042-7736$ & Leroy Kauffman & Shoops Well Drilling & 1974 & $\mathbf{H}$ & 840 & $\mathbf{S}$ & Ocn/lmsn \\
\hline 385 & $4041-7737$ & Darvin Yoder & Boward Boyd & 1971 & $\mathbf{H}$ & 760 & $\mathbf{S}$ & Obf/dlmt \\
\hline 386 & $4037-7742$ & John Renno & -- & 1977 & 日 & 880 & $\mathbf{S}$ & Obf/dlmt \\
\hline 387 & $4038-7742$ & Mark Yoder & -- & -- & $\mathbf{U}$ & 860 & $\mathrm{H}$ & Obf/dlmt \\
\hline 388 & $4044-7730$ & Treaster & Shoops Well Drilling & 1980 & 旦 & 840 & $\mathbf{S}$ & Ocn/Imsn \\
\hline 389 & $4043-7733$ & William McNitt & -- & -- & $\mathbf{S}$ & 790 & $\mathbf{S}$ & Obf/dlmt \\
\hline 390 & $4043-7732$ & Howard J. Goss & Howard Boyd & 1968 & H & 760 & $\mathbf{S}$ & Obl/lmsn \\
\hline 391 & $4045-7729$ & William Leister & Shoops Well Drilling & 1977 & H & 860 & H & Ocn!Imsr \\
\hline 392 & $4032-7747$ & James Zook & Shoops Well Drilling & 1982 & H & 1,010 & $\mathbf{S}$ & Ocn/shle \\
\hline 393 & $4033-7748$ & Jacob Kanagy & Boward Boyd & 1984 & 日 & 980 & $\mathbf{S}$ & Ocn/lmsn \\
\hline 394 & $4036-7744$ & David Byler & -- & -- & $\mathbf{S}$ & 865 & S & Obl/lmsn \\
\hline 395 & $4045-7731$ & Leonard Aurand & Shoogs Well Drilling & 1981 & 日 & 775 & $\mathbf{v}$ & Or/shle \\
\hline 396 & $4035-7746$ & Yoder Bros. & Shoops Well Drilling & 1972 & C & 900 & W & Or/shle \\
\hline 397 & $4039-7737$ & Daniel Swarey & R.R. Hornberger & 1967 & H & 805 & $\mathbf{U}$ & Obffdlmt \\
\hline 398 & $4035-7746$ & Kore Peachey & Shoops Well Drilling & 1977 & S & 950 & $\mathbf{S}$ & Obl/Imsn \\
\hline
\end{tabular}


Table 1.--Record of wells--Continued

\begin{tabular}{|c|c|c|c|c|c|c|c|c|c|c|c|}
\hline \multirow{3}{*}{$\begin{array}{l}\text { Well depth } \\
\text { below land } \\
\text { surface } \\
\text { (feet) }\end{array}$} & \multirow{2}{*}{\multicolumn{2}{|c|}{ Casing }} & \multirow{3}{*}{$\begin{array}{l}\text { Depths to } \\
\text { water-bear- } \\
\text { ing zones } \\
\text { (feet) }\end{array}$} & \multicolumn{2}{|c|}{ Static water level } & \multirow{3}{*}{$\begin{array}{l}\text { Reported } \\
\text { yield } \\
\text { (gal/min) }\end{array}$} & \multirow{3}{*}{$\begin{array}{l}\text { Specific } \\
\text { capacity/ } \\
\text { Rate }\end{array}$} & \multirow{2}{*}{\multicolumn{4}{|c|}{$\begin{array}{l}\text { Specific } \\
\text { conduc- }\end{array}$}} \\
\hline & & & & Depth below & Date & & & & & & \\
\hline & $\begin{array}{l}\text { Depth } \\
\text { (feet) }\end{array}$ & $\begin{array}{l}\text { Di ameter } \\
\text { (inches) }\end{array}$ & & $\begin{array}{c}\text { land surface } \\
\text { (feet) }\end{array}$ & $\begin{array}{l}\text { measured } \\
\text { (mo/yr) }\end{array}$ & & & $\begin{array}{c}\text { Hardness } \\
(m g / L)\end{array}$ & $\begin{array}{c}\text { tance } \\
(\mu \mathrm{S} / \mathrm{cm})\end{array}$ & $\mathrm{pH}$ & $\begin{array}{c}\text { Well } \\
\text { number }\end{array}$ \\
\hline 152 & -- & -- & -- & 14 & $04 / 84$ & -- & -- & -- & -- & -- & $368 \mathrm{Mf}$ \\
\hline-- & - & -- & -- & 36 & $04 / 84$ & -- & -- & 308 & 660 & -- & 369 \\
\hline 89 & -- & -- & -- & 64 & $04 / 84$ & -- & -- & -- & -- & -- & 370 \\
\hline 245 & -- & -- & -- & 65 & $04 / 84$ & 8 & -- & 359 & 850 & 7.4 & 371 \\
\hline-- & -- & -- & -- & 55 & $04 / 84$ & -- & -- & 290 & 705 & -- & 372 \\
\hline 150 & 20 & 6 & $80 / 145$ & 16 & $04 / 84$ & 20 & -- & 410 & 745 & -- & 373 \\
\hline 72 & 27 & 6 & $40 / 65$ & 16 & $07 / 68$ & 40 & -- & -- & -- & -- & 374 \\
\hline 122 & 3 & 6 & $47 / 80 / 110$ & 18 & $04 / 84$ & 9 & -- & 290 & 560 & -- & 375 \\
\hline 276 & 60 & 6 & $65 / 260$ & 80 & $06 / 72$ & -- & -- & -- & -- & -- & 376 \\
\hline 276 & 125 & 6 & $175 / 265 / 272$ & 50 & $07 / 72$ & 12 & -- & -- & -- & -- & 377 \\
\hline 201 & 133 & 6 & $140 / 197$ & 60 & $07 / 72$ & -- & -- & 140 & 790 & -- & 378 \\
\hline 200 & -- & -- & -- & 27 & $04 / 84$ & -- & -- & -- & -- & -- & 379 \\
\hline 147 & 40 & 6 & $70 / 130$ & 60 & $06 / 69$ & -- & -- & -- & -- & -- & 380 \\
\hline 150 & -- & -- & -- & 51 & $04 / 84$ & -- & -- & -- & -- & -- & 381 \\
\hline 170 & 20 & 6 & $120 / 150$ & 69 & $04 / 84$ & 20 & $0.40 / 20$ & 137 & 315 & -- & 383 \\
\hline-- & -- & -- & -- & 67 & $04 / 84$ & -- & -- & 239 & 535 & -- & 384 \\
\hline 80 & -- & -- & -- & 13 & $04 / 84$ & -- & -- & 342 & 630 & -- & 385 \\
\hline 180 & -- & -- & -- & 70 & $04 / 84$ & -- & -- & 222 & 465 & -- & 386 \\
\hline 192 & -- & -- & -- & 64 & -- & -- & -- & -- & -- & -- & 387 \\
\hline-- & -- & -- & -- & 99 & $05 / 84$ & -- & -- & 256 & 500 & -- & 388 \\
\hline 120 & -- & -- & -- & 103 & $05 / 84$ & -- & -- & 375 & 745 & -- & 389 \\
\hline 147 & 23 & 6 & 147 & 42 & $05 / 84$ & -- & -- & 256 & 570 & -- & 390 \\
\hline 230 & 20 & 6 & 175 & 129 & $05 / 84$ & -- & -- & 274 & 545 & -- & 391 \\
\hline 200 & -- & -- & -- & 16 & $05 / 84$ & -- & -- & 154 & 310 & -- & 392 \\
\hline 370 & 32 & 6 & -- & 99 & $05 / 84$ & 4 & -- & 85 & 280 & -- & 393 \\
\hline 185 & -- & -- & -- & 46 & $05 / 84$ & -- & -- & -- & 845 & 6.9 & 394 \\
\hline 257 & 10 & 6 & -- & 4 & $05 / 84$ & -- & -- & 68 & 320 & -- & 395 \\
\hline 130 & -- & -- & -- & 3 & $05 / 84$ & 40 & -- & -- & -- & -- & 396 \\
\hline 190 & 60 & 6 & 187 & 54 & $05 / 84$ & 15 & $.20 / 15$ & -- & -- & -- & 397 \\
\hline 360 & 20 & 6 & 120 & 32 & $05 / 84$ & 3 & -- & 393 & 135 & -- & 398 \\
\hline
\end{tabular}




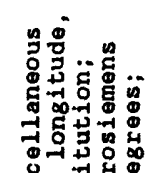

문 군형

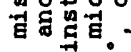

s.

고ำ

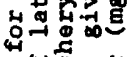

nั0

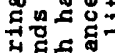

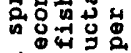

7.

ㅎำ

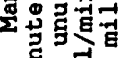

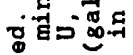

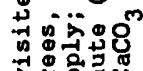

D)

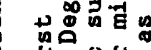

의

ㅇํำ

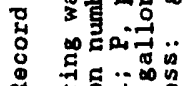

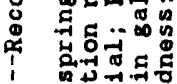

은

is

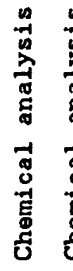

政

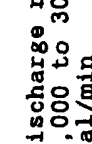

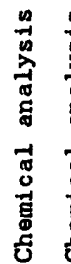

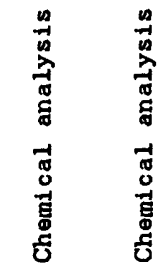

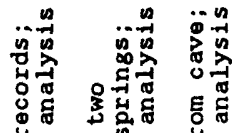

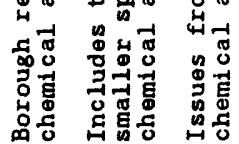

昜

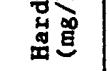

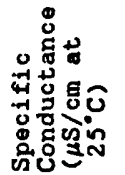

竞: 㟔

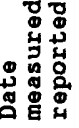

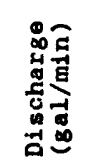

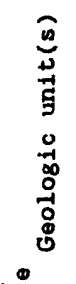

ัะ ํํำ

ํํำ

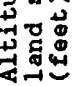

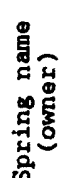

就)

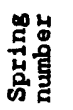

号 号号品:

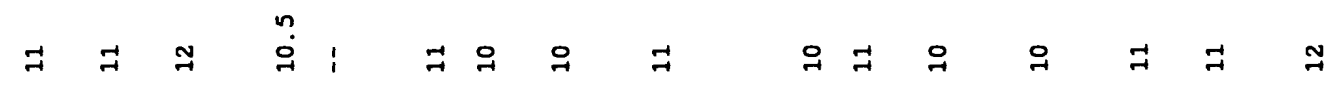

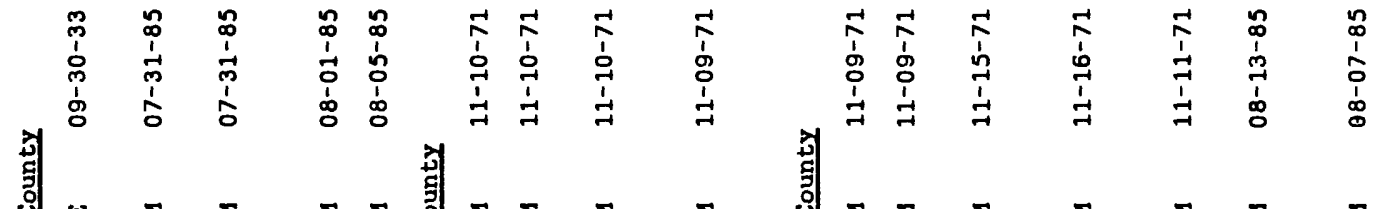

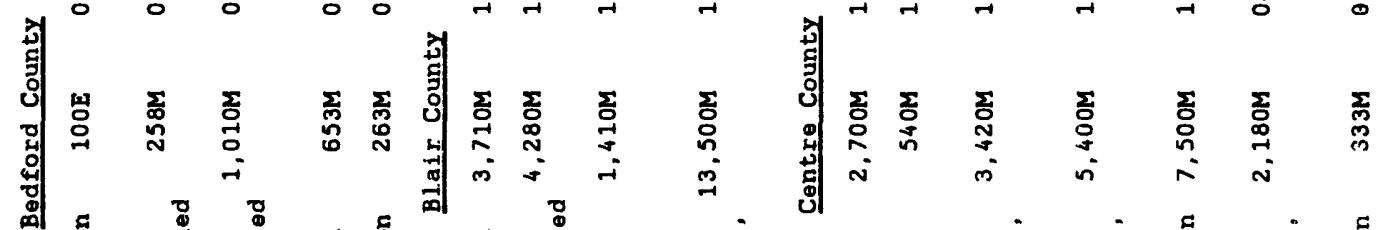

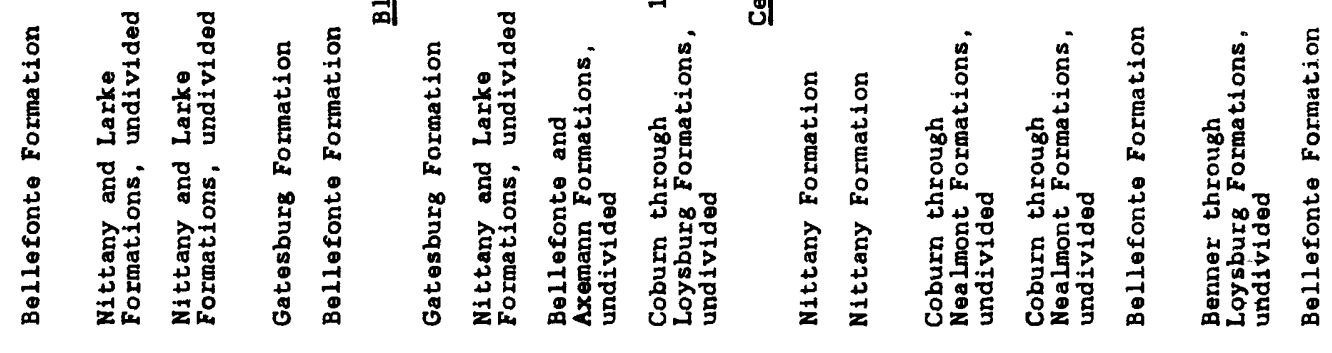

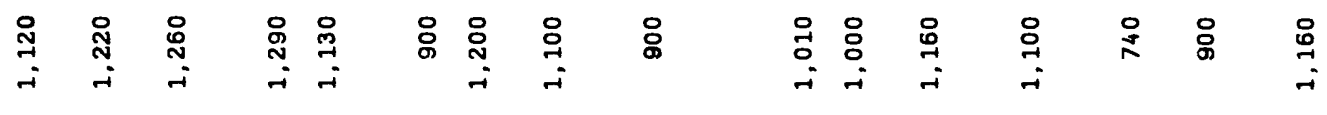

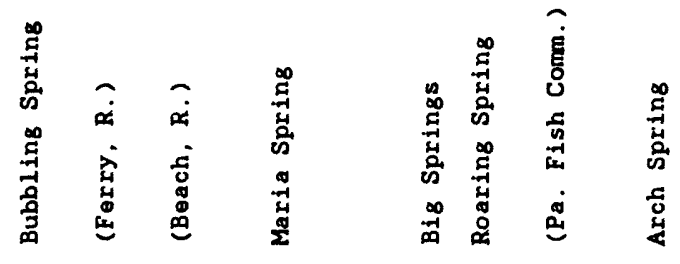

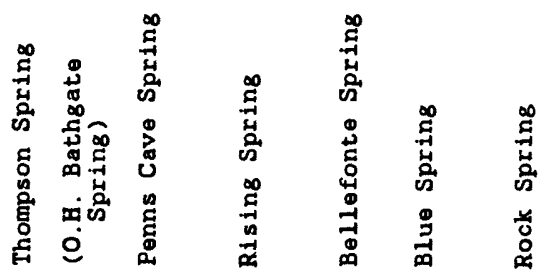

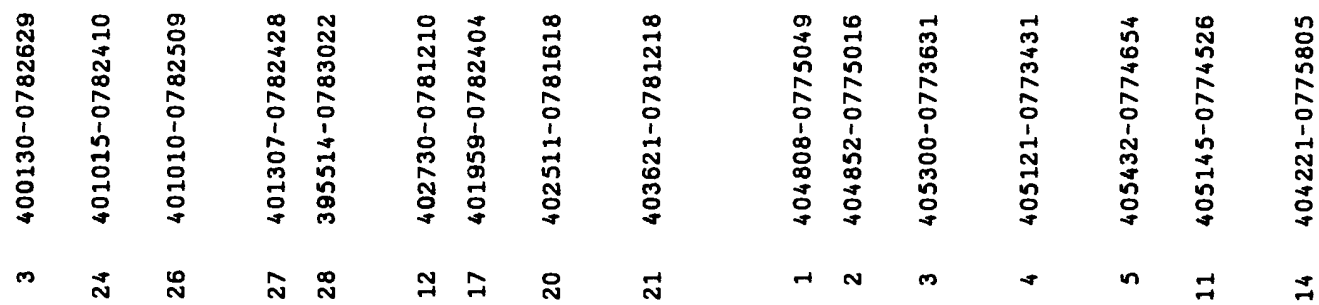




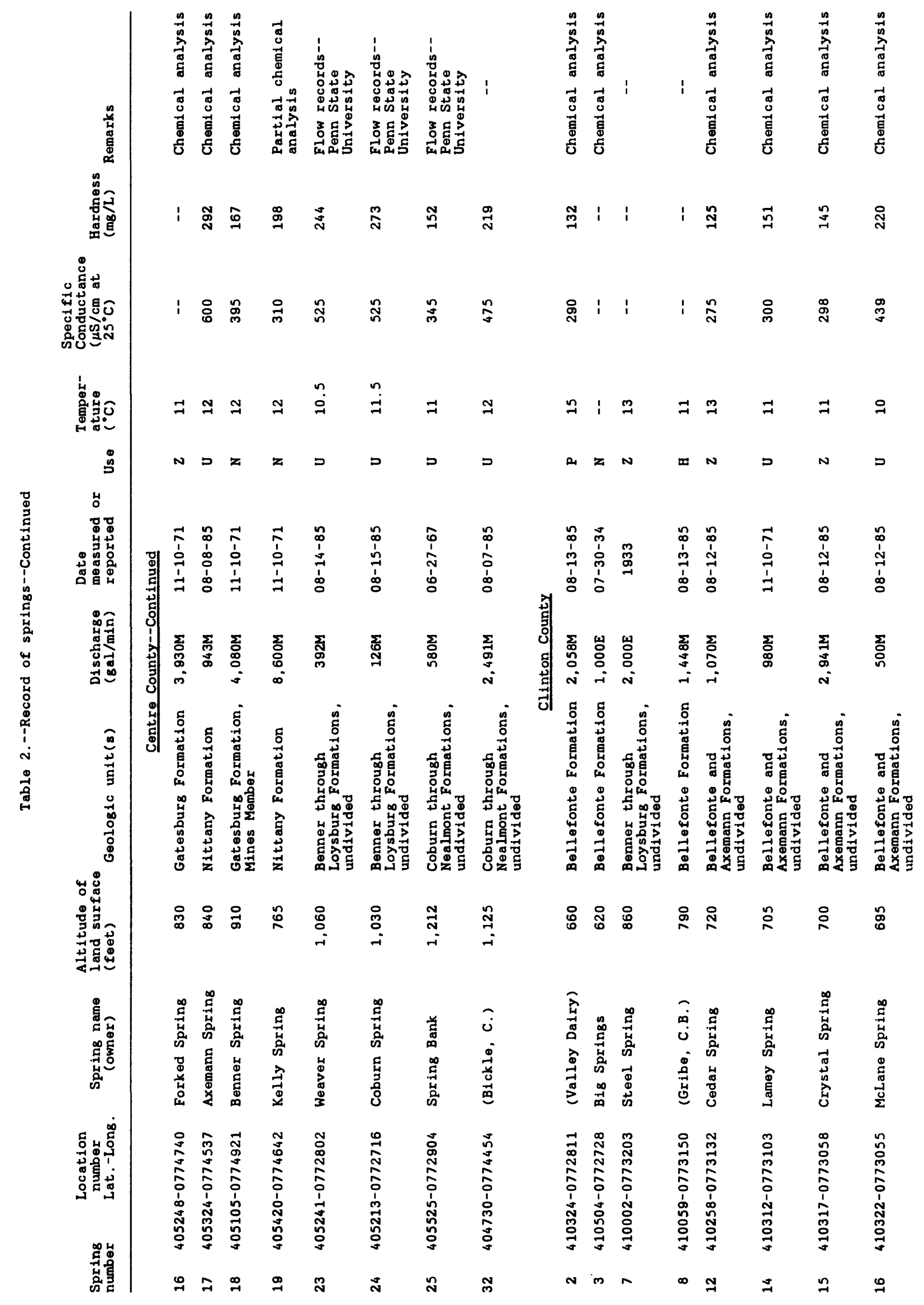




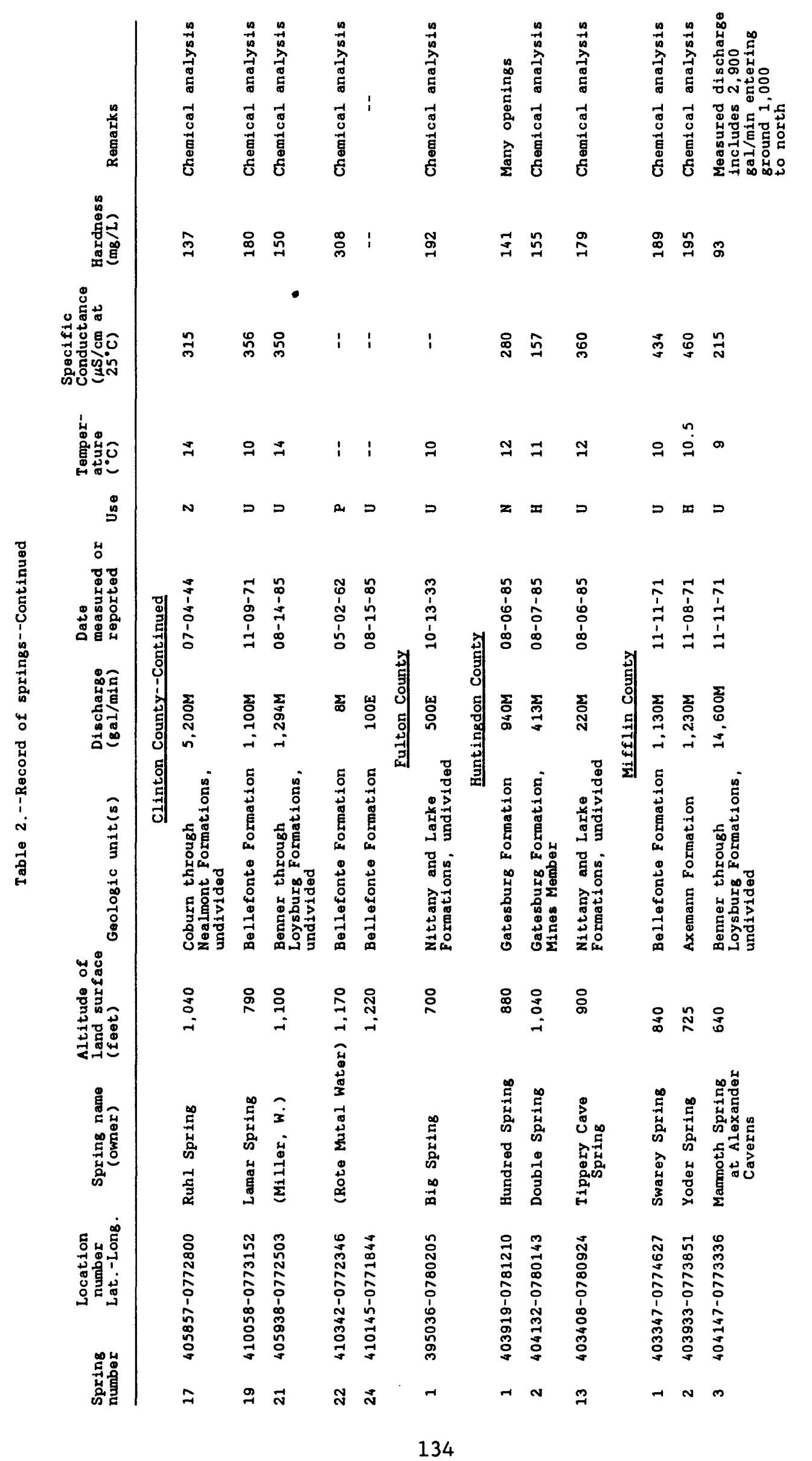

